UNIVERSIDADE DE SÃO PAULO

FACULDADE DE ARQUITETURA E URBANISMO

\title{
OBSOLESCÊNCIA \\ PROGRAMADA, \\ PRÁTICAS DE CONSUMO \\ E DESIGN: \\ UMA SONDAGEM SOBRE \\ BENS DE CONSUMO
}

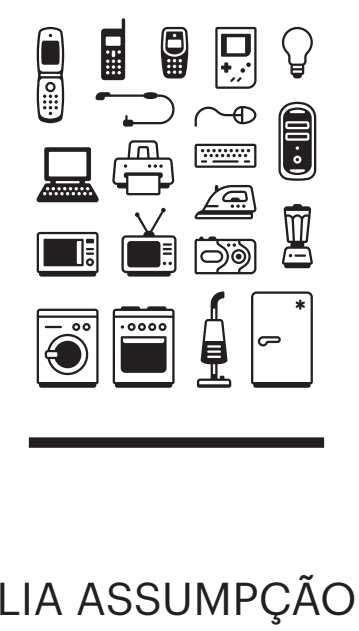

SÃO PAULO 



\section{Lia Assumpção}

\section{Obsolescência programada, práticas de consumo e design:}

uma sondagem

sobre bens de consumo

Versão original

Dissertação apresentada à Faculdade de Arquitetura e Urbanismo da Universidade de São Paulo para obtenção do título de Mestre em Arquitetura e Urbanismo

Área de Concentração: Design e Arquitetura

Orientadora: Profa Dra. Denise Dantas

São Paulo | 2017 
Autorizo a reprodução e divulgação total ou parcial deste trabalho, por qualquer meio convencional ou eletrônico, para fins de estudo e pesquisa, desde que citada a fonte.

e-mail da autora: liaassumpcao@me.com

A8510 Assumpção, Lia

Obsolescência programada, práticas de consumo e design: uma sondagem sobre bens de consumo / Lia Assumpção; orientador Denise Dantas. - São Paulo, 2017. $228 p$.

Dissertação (Mestrado) - Faculdade de Arquitetura e Urbanismo da Universidade de São Paulo. Área de concentração: Design e Arquitetura

1. Obsolescência Programada. 2. Design de Produtos. 3. Consumismo. 4. Design Industrial. I. Dantas, Denise, orient. II. Título. 
Para Miguel e Felipe 


\section{Agradecimentos}

Comecei a escrever esta dissertação por aqui. Porque não seria possível imprimir todas as páginas que seguirão não fosse a ajuda de muitas pessoas com as quais tenho o privilégio de conviver ou que tive a oportunidade de conhecer.

Um agradecimento inicial ao Rodrigo, que imprimiu o projeto de pesquisa e fez minha inscrição na FAU e viu meu nominho na lista dos aprovados antes de mim.

À profa. dra. Denise Dantas, por sua orientação no sentido amplo da palavra, no projeto, no caminho acadêmico e nas conversas. Agradeço a todas as discussões e toda a paciência com as idas e vindas do projeto, do texto e do meu pensamento.

Um agradecimento muito especial à minha amiga Mariana Clauzet, que de onde quer que estivesse, leu, opinou, corrigiu e me falou para continuar! Me ajudou com o questionário, com a dissertação final, com as inseguranças todas do percurso e com muitas as dicas para o ingresso nesse "novo mundo" acadêmico. E aqui também um agradecimento à minha amiga Isabel, afinal somos um trio no qual uma sempre ajuda a outra, às vezes de maneiras imperceptíveis.

Agradeço a Ricardo Teperman e José Guilherme Pereira Leite, amigos acadêmicos inspiradores. A Carol Vargas e Denio Benfatti, os padrinhos deste trabalho. Agradeço a crítica ao meu projeto inicial e o incentivo a seguir em frente; todas as ajudas durante $o$ período de mestrado e toda a paciência em me ouvir falar desse assunto tantas vezes...

À Profa. dra. Daniela Hans, obrigada por me incentivar a prestar o exame de mestrado, quando imaginei que me mandaria pra casa estudar. Ao Prof. dr. Cláudio Portugal, por todas as críticas sinceras na qualificação, espero estar entregando um trabalho à altura delas. Ao prof. dr. Marcos Braga, pelas aulas inspiradoras e esclarecedoras, e pela oportunidade que me deu em seu projeto de publicações sobre a a história do design. À profa. dra. Cristiane Aun e profa. dra. Maria Cecília Loschiavo dos Santos, pelas aulas, pelos textos, pelas reflexões.

A André Midoes, companheiro para todos os momentos. A Bruna Montuori, interlocutora atenta e generosa.

A Lucia Avelar, pela ajuda fundamental com o questionário e pelos cafés agradáveis. A Eduardo Lazzari, pela ajuda com os dados levantados e por sua paciência para as intermináveis e repetitivas perguntas. Ao revisor Luiz Fukushiro, pela gentileza e rapidez! 
Agradeço aos entrevistados e a todas as pessoas que contribuíram com seus depoimentos no Facebook e no questionário.

A Carla Castilho, minha sócia-irmã, pela grande parceria nessa vida; obrigada pelas conversas sobre a obsolescência, pelo moço da bateria, pelo ombro nas horas de desespero, por ter tocado o estúdio praticamente sozinha nesses tempo de mestrado. A Fefa, pelas mesmas conversas sobre $o$ artigo, o projeto, o capítulo, a diagramação, a capa. Nossos almoços fazem parte deste mestrado.

A Ciça Pinheiro, por me ajudar a transcender um pouco o agora e o pequeno; por me ajudar a pensar no grande, a pensar no ali, mas ainda daqui.

A Flávia Pegorin e a Giuliana Bergamo, minhas jornalistas preferidas, que, além de divulgar com afinco meu questionário, angariando muitas respostas, me auxiliaram muito na escrita, lendo e editando muitas palavras escritas aqui.

A Paula Signoreli, minha parceira na redação.

Agradeço a minha mãe Cida, ao meu pai Thomaz e ao meu segundo pai Murillo afinal foram vocês que plantaram em mim a semente que semeio aqui; à Sonia Barreira, à minha madrinha Fátima, aos meus sogros Yara e Fonseca. De alguma maneira, todos me ajudaram dizendo que ia dar certo, dizendo "eu pego o Miguel na escola" ou "o Felipe pode ficar aqui em casa hoje", ou mesmo me dando um abraço quando a culpa de ficar longe dos meninos me pegou...

Finalmente, agradeço e dedico esse trabalho aos meus pequenos Miguel e Felipe, que, sem saber, me inspiraram (e inspiram!) e por isso me ajudaram a pesquisar um tema caríssimo a mim. Espero que possam se beneficiar de alguma maneira das coisas que ouviram nos dois anos e meio de mestrado, nas suas futuras vidinhas (Felipe, colega de disciplinas no primeiro ano do mestrado, ainda na minha barriga).

Um agradecimento final para o moço que imprimiu meu trabalho e fez a minha inscrição na FAU; viajou com os meninos quando o prazo foi chegando ao fim; me abraçou quando eu achei que não daria certo, não daria tempo ou que não importava mesmo...; que fez o jantar, lavou a louça, fez o pesadelo do sono dormir e ainda leu todas as páginas que seguem. Sem você, meu Lucio, não estava aqui impresso. 



\section{Resumo}

Esta pesquisa, de caráter qualitativo exploratório, procurou identificar manifestações de obsolescência programada presentes atualmente no mercado brasileiro, assim como os principais produtos relacionados a ela. A maneira como artefatos são produzidos e comercializados desde a implementação da obsolescência programada estão colocando a sociedade frente a uma limitação ambiental no que diz respeito ao esgotamento dos recursos e um crescimento alarmante na geração de lixo eletrônico. Frente a essa limitação, modelos de consumo e fabricação são questionados. Considerando o design como uma atividade engajada intrinsecamente nas questões sociais, ele pode ser uma importante ferramenta para modificar este cenário. A pesquisa baseou-se nas definições de obsolescência programada elaboradas por Packard, Papanek e Slade para definir parâmetros conceituais que possibilitassem a identificação da obsolescência programada por meio de práticas de consumo. Foi usado como método de coleta de dados um questionário para identificar a percepção dos consumidores e entrevistas com designers para tentar estabelecer uma relação entre o fenômeno estudado e o design. Os produtos mais citados foram telefones celulares e computadores. Durabilidade mostrou-se pouco importante para aparelhos com rápida evolução tecnológica como o telefone celular. Para produtos sem essa característica tecnológica, durabilidade mostrou-se rara, pois, de acordo com o resultado da pesquisa, há uma grande associação entre materiais baratos e frágeis, que comprometem a durabilidade dos produtos. Apesar de o resultado permitir identificar os três tipos de obsolescência programada determinados pelos autores - artificial, psicológica e tecnológica - a pesquisa concluiu que o conceito de obsolescência programada, da maneira como foi criado, está tão assimilado nos dias de hoje que acaba por tornar o termo em si obsoleto. Isso porque hoje produtos não precisam ser feitos para quebrar para que sejam trocados e muitas vezes descartados.

Palavras-chave: obsolescência programada; design de produtos; consumismo; design industrial. 



\section{Abstract}

This exploratory qualitative research tried to identify planned obsolescence's manifestations in the Brazilian market, as well as the main products related to it. The way consumer goods have been produced and sold since the planned obsolescence's implementation is leading society to an environmental limitation in terms of natural resources and alarming growth in the generation of electronic waste. Consumption the way it is and manufacturing are questioned, faced with this limitation. Considering design as an activity intrinsically engaged in social issues, it can be an important tool to modify this scenario. The research was based on planned obsolescence and on conceptual parameters by Packard, Papanek and Slade, which allowed the identification of planned obsolescence through consumption practices. As a method, a questionnaire to identify consumer perception and interviews with designers tried to establish a relationship between the studied phenomenon and the design. The most cited products were cell phones and computers. Durability proved to be unimportant for devices with rapid technological evolution such as cell phones. For products without this technological characteristic, durability proved to be rare, as according to the research results there is a great association between cheap and fragile materials, which compromise the durability of the products. Although the result allows to identify the three types of programmed obsolescence determined by the authors - artificial, psychological and technological - , the research concluded that the concept of programmed obsolescence, in the way it was created, is so assimilated today that it ends up making the term itself obsolete. This is because today products do not have to be made to break to be changed and often discarded.

Keywords: programmed obsolescence; product design; consumerism; industrial design. 


\section{Lista de figuras}

Figura 1. Cell phones, Orlando 2004. (Fonte: Ensaio fotográfico de Chris Jordan Intolerable Beauty: Portraits of American Mass Consumption 2003 - 2005. Disponível em http://www.chrisjordan.com/gallery/intolerable/\#cellphones\%2044x83)_p. 14-15 Figura 2. Imagens que ilustram locais de de descarte de lixo eletrônico. (Fonte: http://www.fragmaq.com.br/ blog/entenda-conceito-obsolescencia-programada-impactos-meio-ambiente/) p. 21

Figura 3. Crushed cars \#2, Tacoma 2004. (Fonte: Ensaio fotográfico de Chris Jordan Intolerable Beauty: Portraits of American Mass Consumption 2003 - 2005. Disponível em http://www.chrisjordan.com/gallery/intolerable/\#crushed\%20 cars $\% 202 \% 20 \% 2044 \times 62$ )

p. 32-33

Figura 4. Carro da Chrysler em 1957, motrando a roupa que combina com o carro. (Fonte: https://www.hemmings. com/blog/2014/02/15/four-links-larry-watsons-rainbow-cars-prop-car-african-americans-in-auto-advertising-geobaker/) p. 39

Figura 5. Anúncio Chevrolet de 1957, associação do desenho dos carros com os aviões. (Fonte: http://www. carrosyclasicos.com/historia/item/525-chevrolet-1955,-casi-60-a\%C3\%B1os-de-historia) p. 39

Figura 6. O Model T da Ford. (Fonte: https://carrosantigos.wordpress.com/2008/07/25/100-anos-do-ford-modelo-t/) p. 39 Figura 7. Modelos de carro da GM na década de 1956. (Fonte: http://omnibusofspeed.tumblr.com/post/71571048768/ theniftyfifties-general-motors-1956-models) p. 39

Figura 8. Linha do tempo de acordo com Slade (2007). p. 47

Figura 9. Anúncio da Ford de 1926. (Fonte: http://www.fordmodelt.net/gallery2/index.php?/category/11) p. 49

Figura 10. Anúncio da Volkswagen de 1963. (Fonte: http://www.plosin.com/beatbegins/projects/haine/volks2.htm) p. 49

Figura 11. Promoção de pasta de dente. p. 56

Figura 12. Banheiro na década de 1930. (Fonte: Forty, 2007, p. 228) p. 64

Figura 13. Banheiro nos dias de hoje. (Fonte: https://minhacasa.abril.com.br/decoracao/banheiro-elegante-perfeito-para-familia-toda/) p. 64

Figura 14. Imagens extraídas do site da BMW (Fonte: www.bmw.pt) p. 69

Figura 15. Circuit boards \#2, New Orleans 2005. (Fonte: Ensaio fotográfico de Chris Jordan Intolerable Beauty: Portraits of American Mass Consumption 2003 - 2005. Disponível em http://www.chrisjordan.com/gallery/intolerable/\#circuit\%2oboards\%202\%2044x60)

p. 78-79

Figura 16. Cell phone chargers, Atlanta 2004. (Fonte: Ensaio fotográfico de Chris Jordan Intolerable Beauty: Portraits of American Mass Consumption 2003 - 2005. Disponível em http://www.chrisjordan.com/gallery/intolerable/\#cellphone\%20 chargers\%2044x66.5)

p. 90-91

Figura 17. Fogão da marca Westinghouse (1960). (Fonte: www.etsy.com/pt/listing/241341195/1960s-westinghouse-range-ad-retro?ref=market.) p. 120

Figura 18. Fogão Brastemp (2016). (Fonte: http://www.econovia.com.br/produtos/forno-fogao/fogao-brastemp-ativetop-glass-maxi-duplo-forno-inox-bfd4var-4-bocas/54483ab6d58fo2318600oood.)

p. 120

Figura 19. Geladeira Northstar (1950). (Fonte: http://indulgy.com/post/IghIXNcv93/northstar-retro-appliances-ranges-refridgerator.)

p. 120

Figura 20. Geladeira Brastemp (2016). (Fonte: http://www.brastemp.com.br/produto/geladeira-brastemp-side-inverse-branca-540l/\#cor=cor-inox.) p. 120

Figura 21. Máquina de lavar e de secar da marca Westinghouse (1957). (Fonte: www.flickr.com/photos/peppermint_kiss_kiss/4339679433/in/photostream.) p. 120 
Figura 22. Máquina de lavar e de secar (2016). (Fonte: http://www.tudoconstrucao.com/modelos-de-lavanderias-pequenas-dicas-sugestoes.)

Figura 23. Celular Apple (iphone 7 S Plus). (Fonte: http://www.infomoney.com.br/minhas-financas/gadgets/noticia/6000081/anos-desde-primeiro-iphone-confira-evolucao-smartphone)

p. 135

Figura 24. Celular Samsung Galaxy S8. (Fonte: https://www.magazineluiza.com.br/smartphone-samsung-galaxy-s864gb-preto-dual-chip-4g-cam.-12mp-selfie-8mp-tela-5.8-quad-hd/p/2175625/te/gas8/.)

p. 135

Figura 25. Circuit boards, Atlanta 2004. (Fonte: Ensaio fotográfico de Chris Jordan Intolerable Beauty: Portraits of American Mass Consumption 2003 - 2005. Disponível em http://www.chrisjordan.com/gallery/intolerable/\#circuit\%20 boards $\% 2044 \times 64$ ) p. 144-145

Figura 26. E-waste, New Orleans 2005. (Fonte: Ensaio fotográfico de Chris Jordan Intolerable Beauty: Portraits of American Mass Consumption 2003 - 2005. Disponível em http://www.chrisjordan.com/gallery/intolerable/\#ewaste\%2044x57)

p. 152-153

\section{Lista de gráficos}

Gráfico 1: Opções de Pagamento p. 96

Gráfico 2: Concordância com as frases p. 97

Gráfico 3: Associação renda familiar mensal e relevância da assistência técnica p. 105

Gráfico 4: Motivos por não ter sido possível consertar p. 107

Gráfico 5: Associação do bem adquirido e o motivo da aquisição p. 113

Gráfico 6: Motivo da compra de produtos novos (399 respondentes) p. 114

Gráfico 7: Motivo da compra de produtos novos relacionado com os tipos de obsolescência programada (295 respondentes) p. 116

Gráfico 8: Motivações para a troca na pesquisa do IDEC p. 117

Gráfico 9: Setores empresariais associados à obsolescência programada p. 137

\section{Lista de quadros}

Quadro 1: Tipos de obsolescência: nomenclatura adotada na pesquisa p. 53

Quadro 2: Produtos mais citados nas coletas de dados de acordo com categoria p. 111

Quadro 3: Motivo da compra relacionado com os tipos de obsolescência programada p. 115 


\section{Sumário}

1 Introdução —_ 17

1.1 Contextualização da pesquisa

1.2 Questão de pesquisa 25

1.3 Objetivos da pesquisa 25

1.4 Definição dos principais conceitos utilizados na pesquisa 26

1.5 Delimitações da pesquisa 28

1.6 Justificativas da pesquisa 28

1.7 Estrutura da dissertação 30

2 Referencial teórico 35

2.1 Breve histórico da obsolescência programada _ 37

2.2 Definições de obsolescência programada — 50

2.3 Práticas de consumo

2.4 Consumismo (ou danos colaterais) _ 59

2.5 A relação entre o design e a obsolescência programada: uma comparação entre a década de 1940 e a década de 1970 e conceitos atuais de design

2.6 A relação entre o design e a obsolescência programada: casos contemporâneos 68

2.7 Futuros possíveis 72

3 Materiais e métodos 81

3.1 Caracterização da pesquisa _ 81

3.2 Etapa 1: procedimento para coleta de dados sobre o histórico do fenômeno e definição dos parâmetros conceituais para a identificação da obsolescência programada atualmente

3.3 Etapa 2: procedimento para coleta de dados sobre práticas de consumo relacionadas com a obsolescência programada, conhecimento do termo e do fenômeno e principais produtos citados pelos participantes da pesquisa 
3.4 Etapa 3: procedimento para coleta de dados sobre o papel do design no desenvolvimento de produtos de larga escala e sua consequente relação com a obsolescência programada 86

3.5 Procedimento para análise e tratamento dos dados coletados _ 87

4 Resultados e discussão 93

4.1 Práticas de consumo identificadas na pesquisa 296

4.1.1 Associação entre o conceitos: novo e bom; velho e ruim; caro e durável; barato e frágil _ـ 97

4.1.2 Durabilidade 102

4.1.3 Assistência técnica — 105

4.2 Principais produtos citados na coleta de dados e tipos de obsolescência programada identificados $\longrightarrow 110$

4.2.1 Obsolescência artificial —— 117

4.2.2 Obsolescência psicológica — 121

4.2.3 Obsolescência tecnológica — 124

4.2.4 Celular: o produto mais citado 126

4.3 O design dentro das empresas estudadas

4.4 Conhecimento sobre o fenômeno da obsolescência programada _ 136

5 Considerações finais 147

5.1 Sugestões para futuras pesquisas 150

Referências bibliográficas — 155

Apêndice 1 (modelo de questionário) — 159

Apêndice 2 (roteiro para entrevistas) 163

Anexo 1 (Relatório CEA-USP) — 165

Anexo 2 (Relatório com os dados levantados no questionário) __ 181 


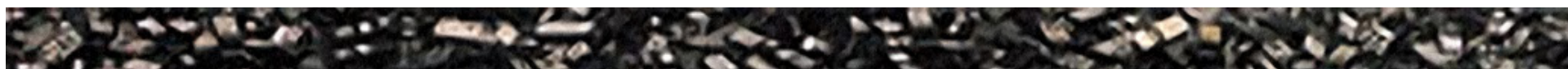

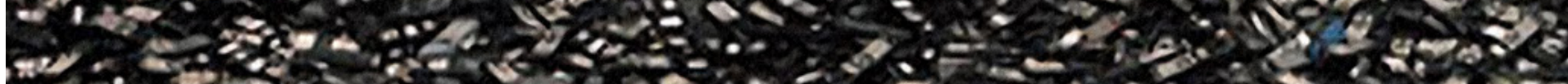

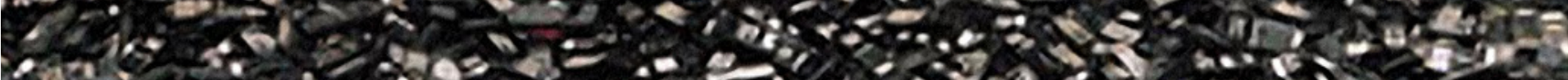

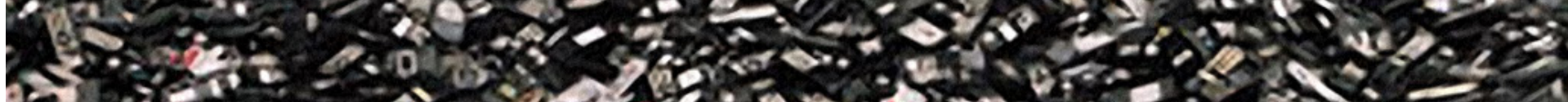

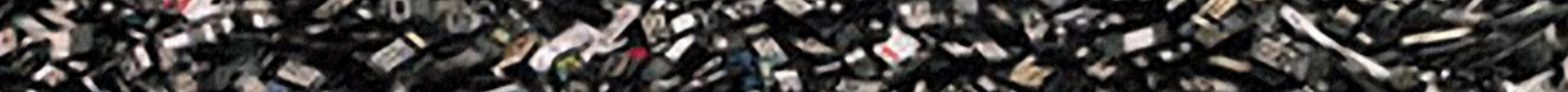

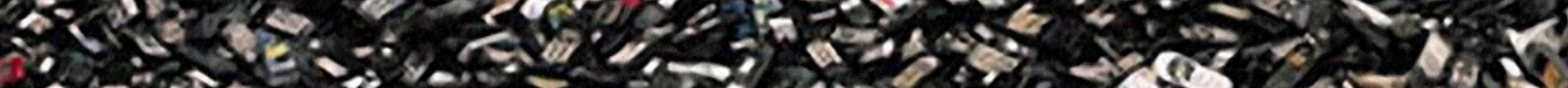

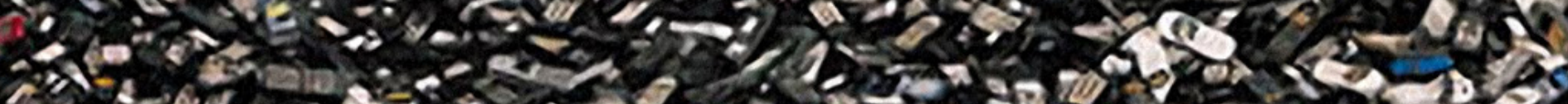

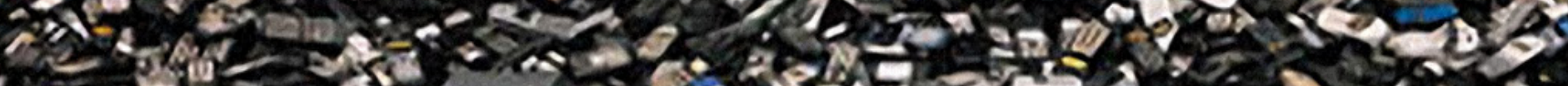

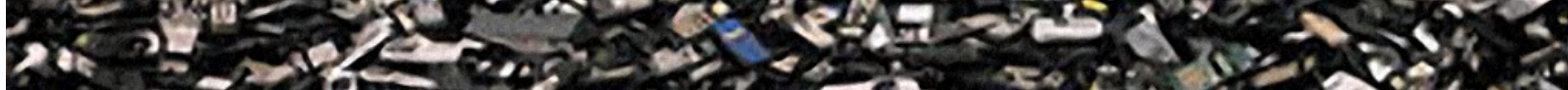
(2) $\therefore$ S.

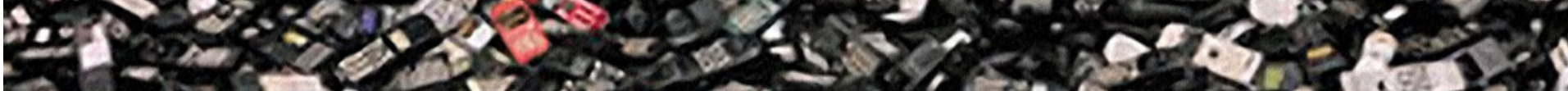
1.7.2.

.

3080

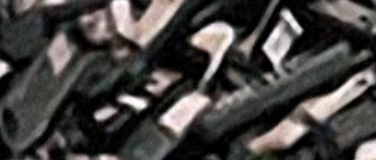

ce.

13

$-205$

10.53

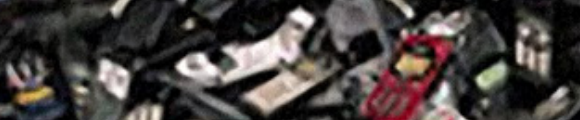

comes a

-

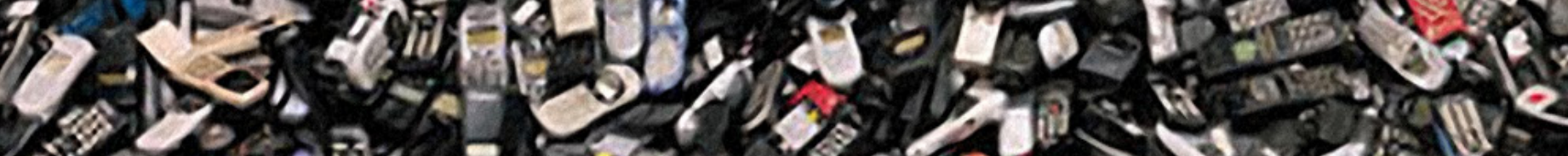
8 (1)

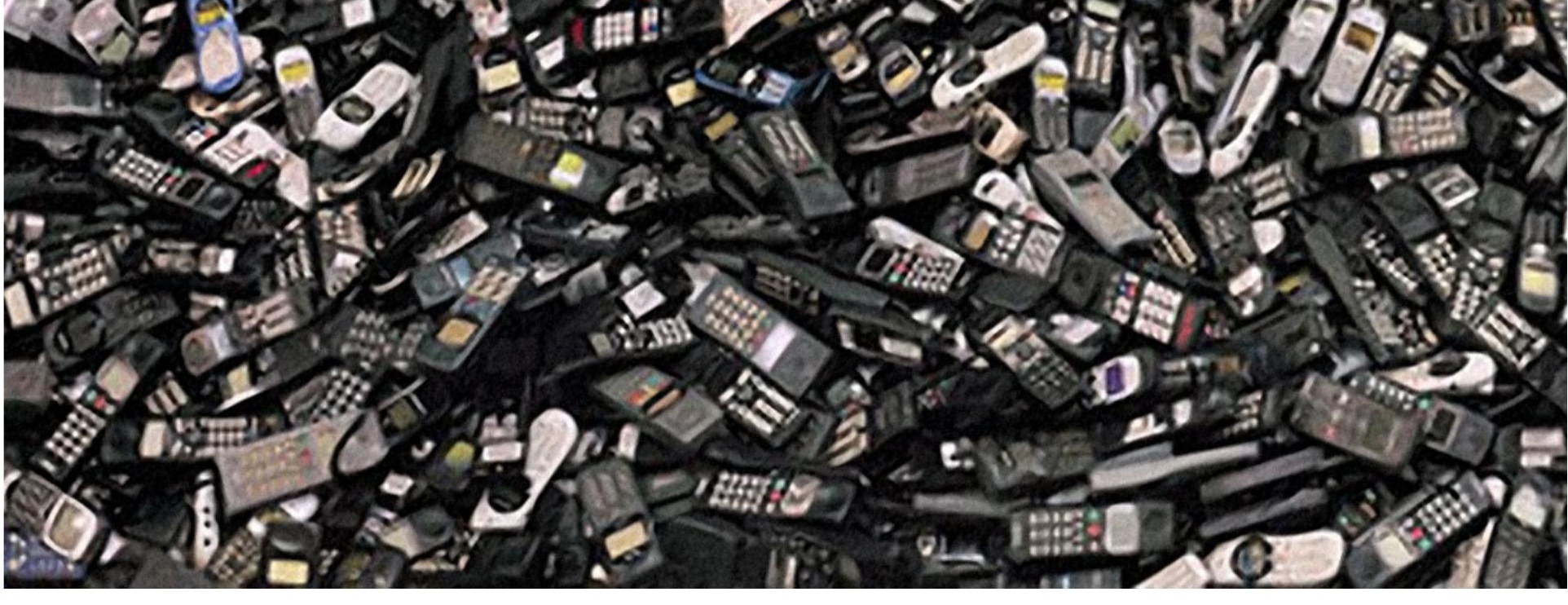




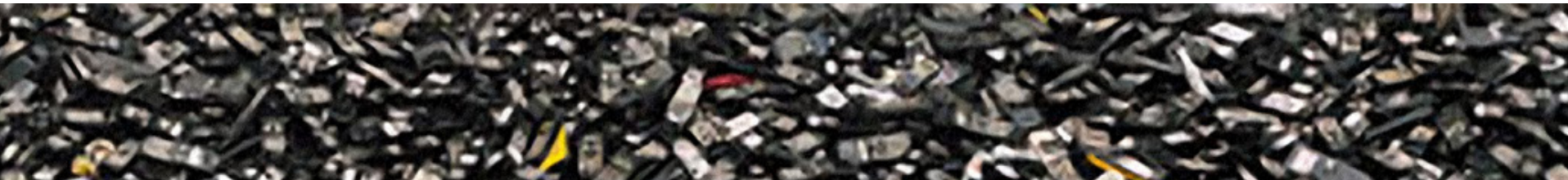

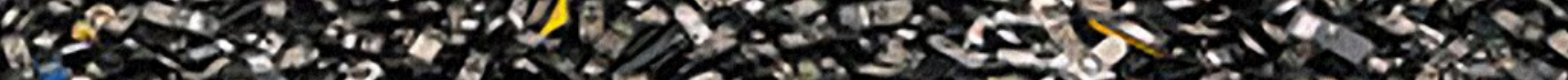
(1)

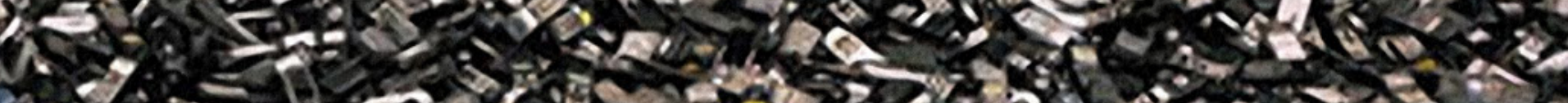

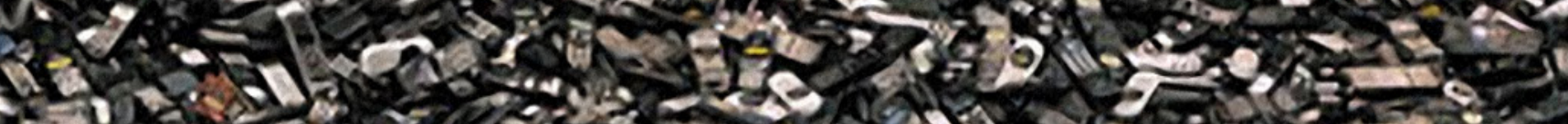

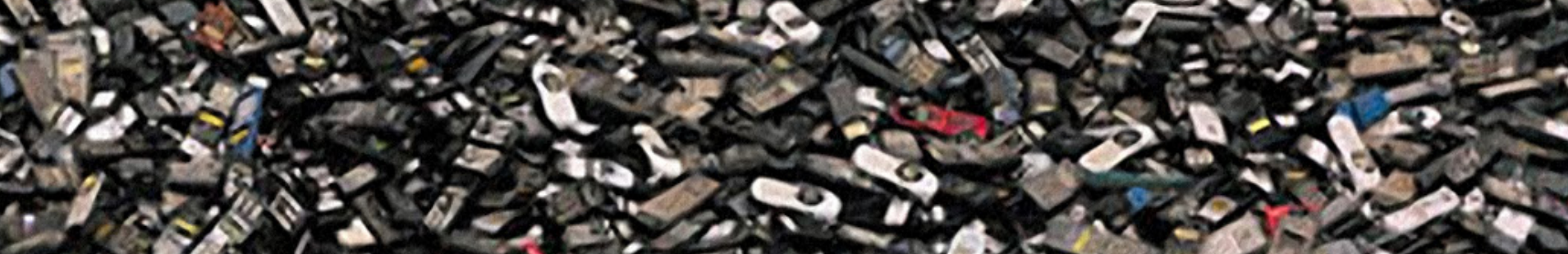

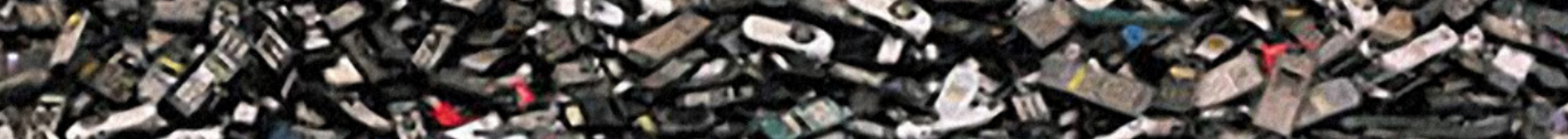

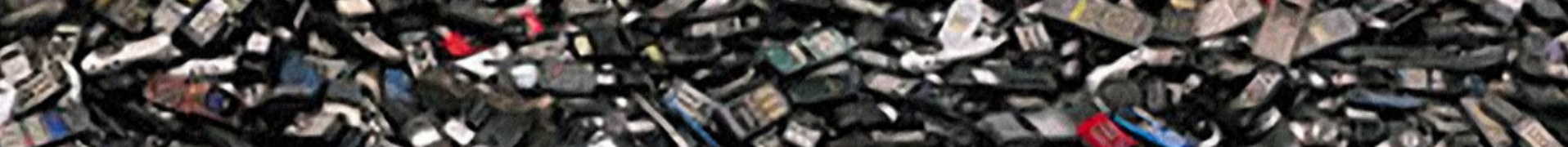

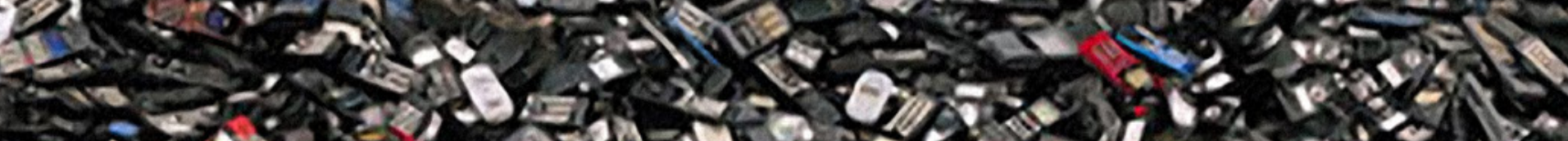

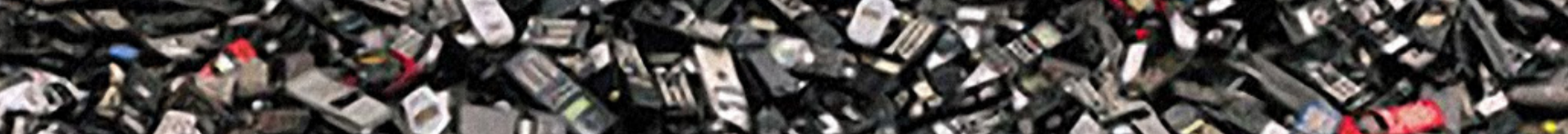
Do 5 - ar $=503$.

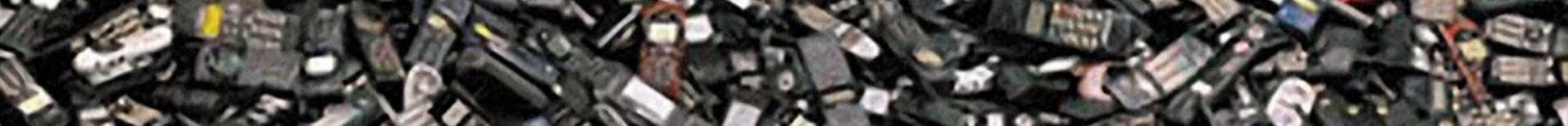

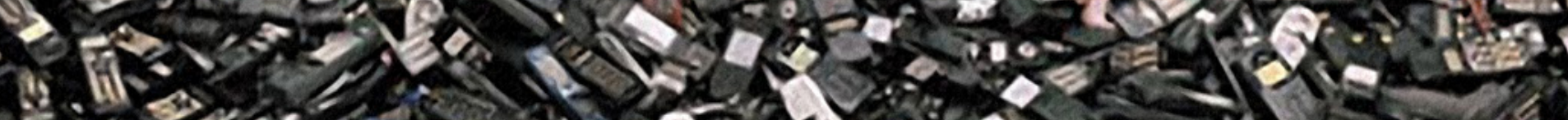
-

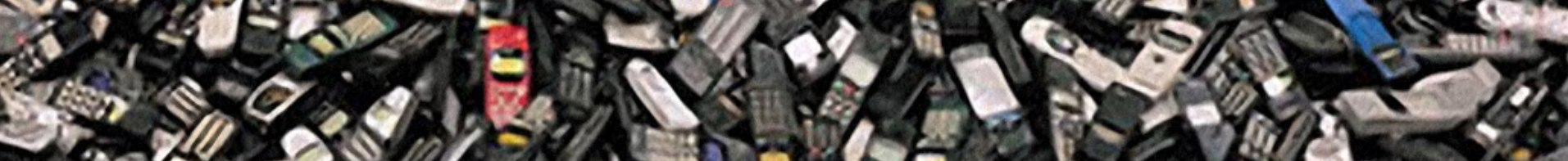

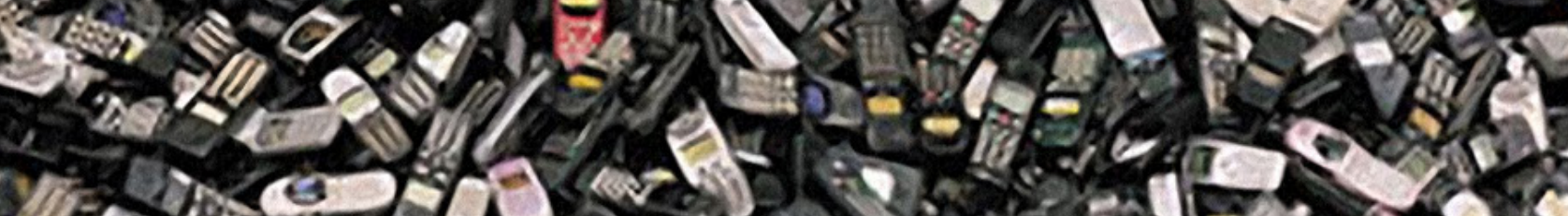

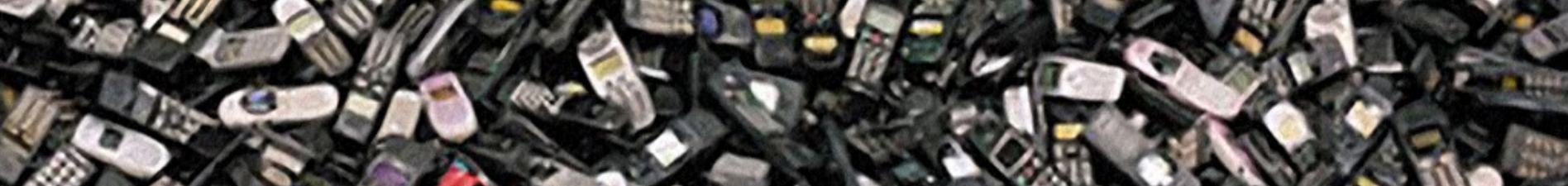

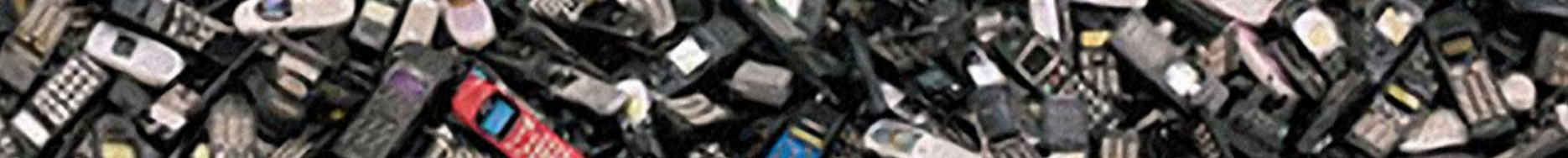

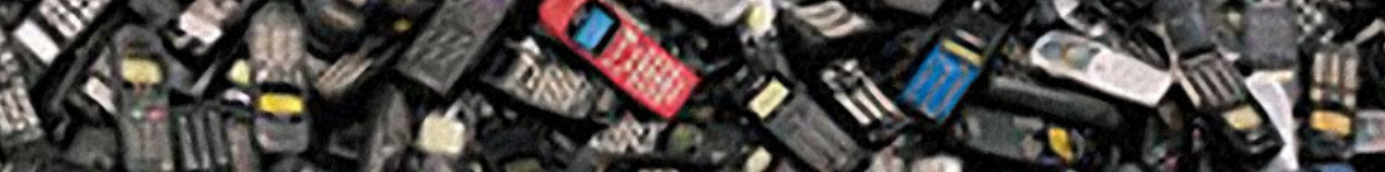

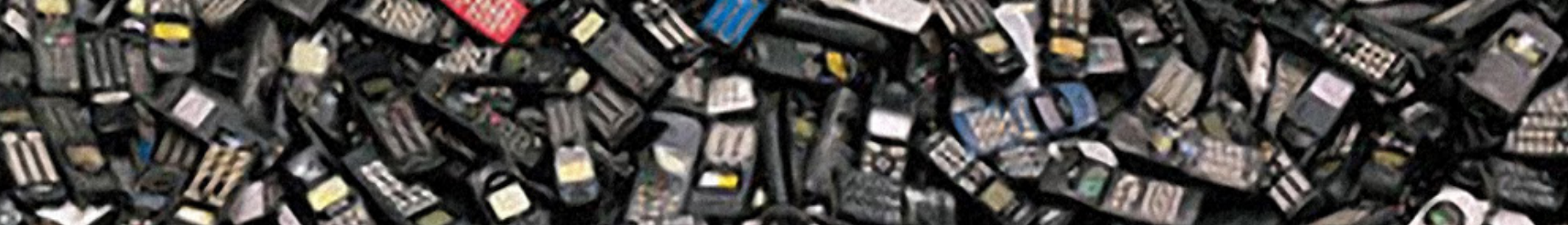

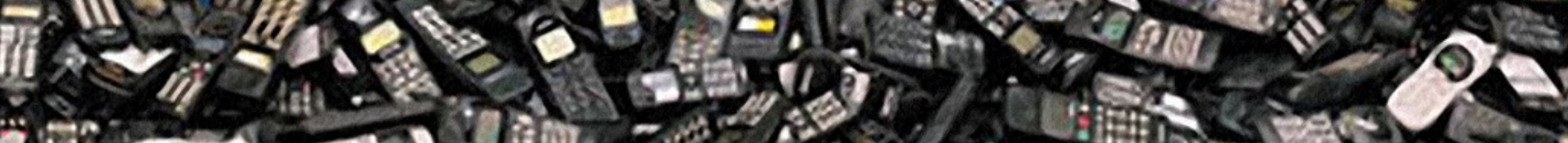
ac $b-10$

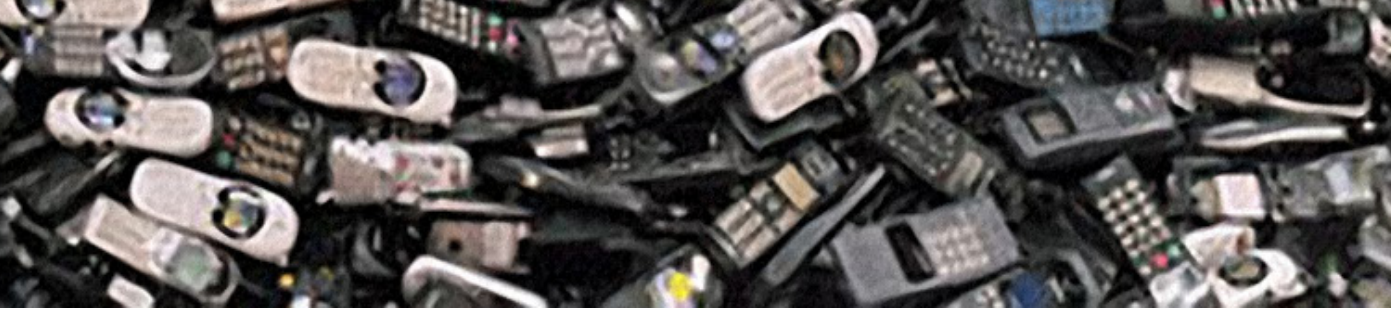




\section{$<$ na página anterior}

Figura 1. Cell phones, Orlando 2004.

(Fonte: Ensaio fotográfico de Chris Jordan Intolerable Beauty: Portraits of American Mass Consumption 2003 - 2005 Disponível emhttp://www.chrisjordan.com/gallery/intolerable/\# cellphones\%2044x83) 


\section{1 \\ Introdução}

\subsection{Contextualização da pesquisa}

Não só tubos retorcidos de pasta de dente, lâmpadas queimadas, jornais, recipientes, materiais de embalagem, mas também aquecedores, enciclopédias, pianos, aparelhos de jantar de porcelana [...]. Quanto mais Leônia se supera na arte de fabricar novos materiais, mais substancioso tornase o lixo, resistindo ao tempo, às intempéries, à fermentação e à combustão. É uma fortaleza de rebotalhos indestrutíveis que circunda Leônia, domina-a de todos os lados como uma cadeia de montanhas. (CALVINO, 2000, p. 105-106)

A citação acima descreve a cidade fictícia de Leônia. Criada por Ítalo Calvino, a cidade caracteriza-se por refazer-se a si própria todos os dias, tornando descartáveis todos os objetos que circundam a vida de seus habitantes e

[...] mais do que pelas coisas que todos os dias são fabricadas, vendidas e compradas, a opulência de Leônia se mede pelas coisas que todos os dias são jogadas fora para dar lugar às novas. Tanto que se pergunta se a verdadeira paixão de Leônia é de fato, como dizem, o prazer das coisas novas e diferentes, e não o ato de expelir, de afastar de si, expurgar uma pureza recorrente. O certo é que os lixeiros são acolhidos como anjos e a sua tarefa de remover restos da existência do dia anterior é circundada de um respeito silencioso, como um rito que inspira a devoção, ou talvez apenas porque, uma vez que as coisas são jogadas fora, ninguém mais quer pensar nelas. (CALVINO, 2000, p. 105) 
A descrição de Leônia remete a práticas de consumo contemporâneas em que produtos, antes duráveis, passam a ter características mais descartáveis. O maior exemplo disso talvez seja o telefone celular. Para além dos símbolos de status que ele representa atualmente, é curioso pensar que ele reúne, hoje, funções de diversos produtos em um só: telefone e câmera, por exemplo. Esses dois produtos que agora embarcam em um único artefato eram classificados como bens de consumo duráveis. Telefones eram caros, grandes e raros, o mesmo valendo para câmeras. No ano de 2014, pouco mais de 70 milhões de celulares foram comercializados no Brasil, segundo os dados da Associação Brasileira da Indústria Elétrica e Eletrônica (Abinee), e até junho de 2017 são aproximadamente 242 milhões de linhas móveis em operação no Brasil, segundo dados da Agência Nacional de Telecomunicações (BRASIL, 2017). De acordo com pesquisa do Instituto Brasileiro de Defesa do Consumidor e da Market Analysis (2013), celulares são trocados num intervalo de tempo que varia de um a três anos.

A cena inicial da série documental inglesa Reis do consumo (THE MAN, 2014), que trata da obsolescência programada, entre outros assuntos relacionados ao consumo, mostra a fila de pessoas em uma loja da Apple, na véspera do lançamento de um novo modelo de iPhone. $O$ apresentador pergunta aos compradores que dormiram na fila sobre as vantagens do novo modelo, e as respostas são, entre outras, uma melhora sutil na câmera, um design um pouco mais fino. Segundo o apresentador, tendo em vista que as mudanças estruturais não são significativas no funcionamento do aparelho, o que faz com que as pessoas durmam em cadeiras de praia ao relento é o status de ser o primeiro a possuir e exibir o novo iPhone. A cena inicial do documentário Obsolescência programada: comprar, tirar, comprar (2010) retrata a impossibilidade de determinado usuário de imprimir um documento. A falha é esclarecida um pouco mais adiante no documentário e é atribuída a um chip que determina o fim das impressões quando se alcança um determinado número de páginas impressas.

Assim como os exemplos acima, muitos outros podem ser citados: liquidificadores que são caros de ser consertados, a peça que fecha a porta do fogão que se quebra e não está mais disponível no mercado por ser um modelo antigo, o computador que não atualiza mais o sistema, a tela quebrada do tablet que caiu no chão e que custa quase o preço de um novo equipamento para ser consertada, o brinquedo que não está alinhado com o último filme lançado no mercado e deixa de ser interessante para as crianças, a máquina de lavar roupa que já foi consertada inúmeras vezes, mas nunca voltou a funcionar direito e até livros didáticos que precisam ser trocados a cada ano, seja pela edição nova lançada, seja pela mudança no acordo ortográfico. 
O exemplo do celular ajuda a compreender as mudanças que ocorreram. Se antes ele era um objeto caro e durável, hoje pode ter preços variáveis se aproximando do conceito de descartável em muitos casos. São diversas marcas e diversos lançamentos por ano. Pequenas melhoras na resolução da câmera, mudanças sutis em seu desenho ou ainda o lançamento de uma nova cor comercializada são atrativos para a troca do aparelho. Por outro lado, impossibilidade ou alto custo de conserto ou mesmo a impossibilidade de atualização de sistema são motivos de troca. Se antes as trocas eram espaçadas, hoje elas são cada vez mais constantes pelos motivos listados acima. Porém, se a troca de celulares ou de outros bens de consumo pode parecer comum ou inevitável hoje, não foi sempre assim, e não foi por acaso. O encorajamento da troca de artefatos passou a vigorar principalmente nos Estados Unidos entre as décadas de 1920 e 1930 para movimentar sua economia, então em crise. Passou-se a reduzir artificialmente o ciclo de vida dos artefatos, valendo-se do que passou a ser chamado de "obsolescência programada", termo cunhado por Alfred Sloan, presidente da General Motors na década de 1920, que aplicou seus conceitos na produção dos carros, como será explorado mais detalhadamente no capítulo 2 desta dissertação.

Obsolescência programada é o nome que se dá à estratégia de mercado que estimula o consumo repetitivo por meio da redução do tempo de vida útil de um produto. De maneira geral, essa redução do tempo de vida do produto pode acontecer de três maneiras: a) pelo lançamento de um produto em uso com uma nova aparência que torna a anterior ultrapassada; b) pela impossibilidade de conserto do produto em uso; c) por sua tecnologia não funcionar mais, tornando lentos alguns dispositivos ou impossibilitando o uso do equipamento em alguns casos.

Segundo Bauman (2008), passamos de uma sociedade de produtores para uma sociedade de consumidores; pouco depois, passamos de uma sociedade de consumidores para uma sociedade consumista. Isso porque a produção dos artefatos deixou de estar alinhada com necessidades, passando a incorporar a ideia de excesso quando ocorreu a industrialização para se chegar a um consumo de massas. "A 'síndrome consumista' envolve velocidade, excesso e desperdício" (BAUMAN, 2008, p. 112).

A prática da obsolescência programada altera não só a produção dos objetos, mas também a maneira de consumi-los, tendo como principal consequência uma grande geração de lixo, devido às trocas frequentes de equipamentos, e no limite afetando também a maneira como vivemos em sociedade, como exposto por Bauman (2008).

A Organização das Nações Unidas (ONU), em seu relatório Waste crime - waste risks (RUCEVSKA et al., 2015), divulgou que o lixo eletrônico gerado no mundo em 2014 
foi de 41,8 milhões de toneladas e estimou que esse número deve subir para 50 milhões em 2018. O Brasil foi responsável por 1,4 milhão de toneladas em 2014, aponta outro relatório da mesma entidade, Gestão sustentável de resíduos de equipamentos eléctricos e eletrônicos na América Latina (2015), com dados sobre a gestão do lixo eletrônico na Argentina, Bolívia, Brasil, Chile, Colômbia, Equador, Paraguai, Uruguai e Venezuela. O documento coloca o Brasil em segundo lugar no ranking dos geradores de lixo eletrônico nas Américas, perdendo apenas para os Estados Unidos, que produziu pouco mais de 7 milhões de toneladas de lixo no mesmo ano, segundo o mapeamento feito pela Step (Solving the E-waste Problem), iniciativa da ONU para mapear o lixo eletrônico no mundo. Segundo o projeto suíço ewasteguide, num levantamento feito entre 2003 e 2011, o Brasil é o quinto maior mercado de produtos eletrônicos do mundo, ficando atrás apenas da China, EUA, Japão e Rússia (SWISS E-WASTE PROGRAMME, 2017).

Os dados de lixo eletrônico têm relação direta com a obsolescência programada, pois remetem a práticas de consumo e uso dos produtos cuja principal característica é o descarte de materiais. Uma pesquisa sobre ciclo de vida de aparelhos eletrônicos, realizada pelo Idec e pelo instituto de pesquisa Market Analysis (2013), ${ }^{1}$ demonstrou a satisfação dos consumidores no que diz respeito ao desempenho e durabilidade dos produtos eletroeletrônicos. Os dados obtidos colocaram a durabilidade planejadamente reduzida dos aparelhos como indutor das vendas. Correlacionando o tempo de posse dos aparelhos com o número de problemas relatados no período pesquisado, o resultado é que, em média, a cada cinco anos, $51,6 \%$ de todos os computadores e $42,3 \%$ de todos os celulares do país apresentaram algum defeito e na maior parte das vezes foram trocados, e não consertados. João Paulo Amaral, pesquisador do Idec, considera que:

Existe o que poderíamos qualificar como uma assimilação conformada do consumidor frente às estratégias da indústria e da propaganda, já que ele percebe "em abstrato" que os aparelhos deveriam durar mais, mas está satisfeito com a durabilidade e desempenho de seu aparelho. (IDEC; MARKET ANALYSIS, 2013)

\footnotetext{
${ }^{1}$ Foram entrevistados, por telefone, 806 homens e mulheres, de 18 a 69 anos, de diferentes classes sociais das seguintes cidades: Belo Horizonte (MG), Brasília (DF), Curitiba (PR), Goiânia (GO), Porto Alegre (RS), Recife (PE), Rio de Janeiro (RJ), Salvador (BA) e São Paulo (SP). O número de entrevistados em cada capital foi proporcional à população de cada capital. O levantamento foi feito entre agosto e outubro de 2013. A margem de erro é de 3,5\% para mais ou para menos (IDEC; MARKET ANALYSIS, 2013).
} 


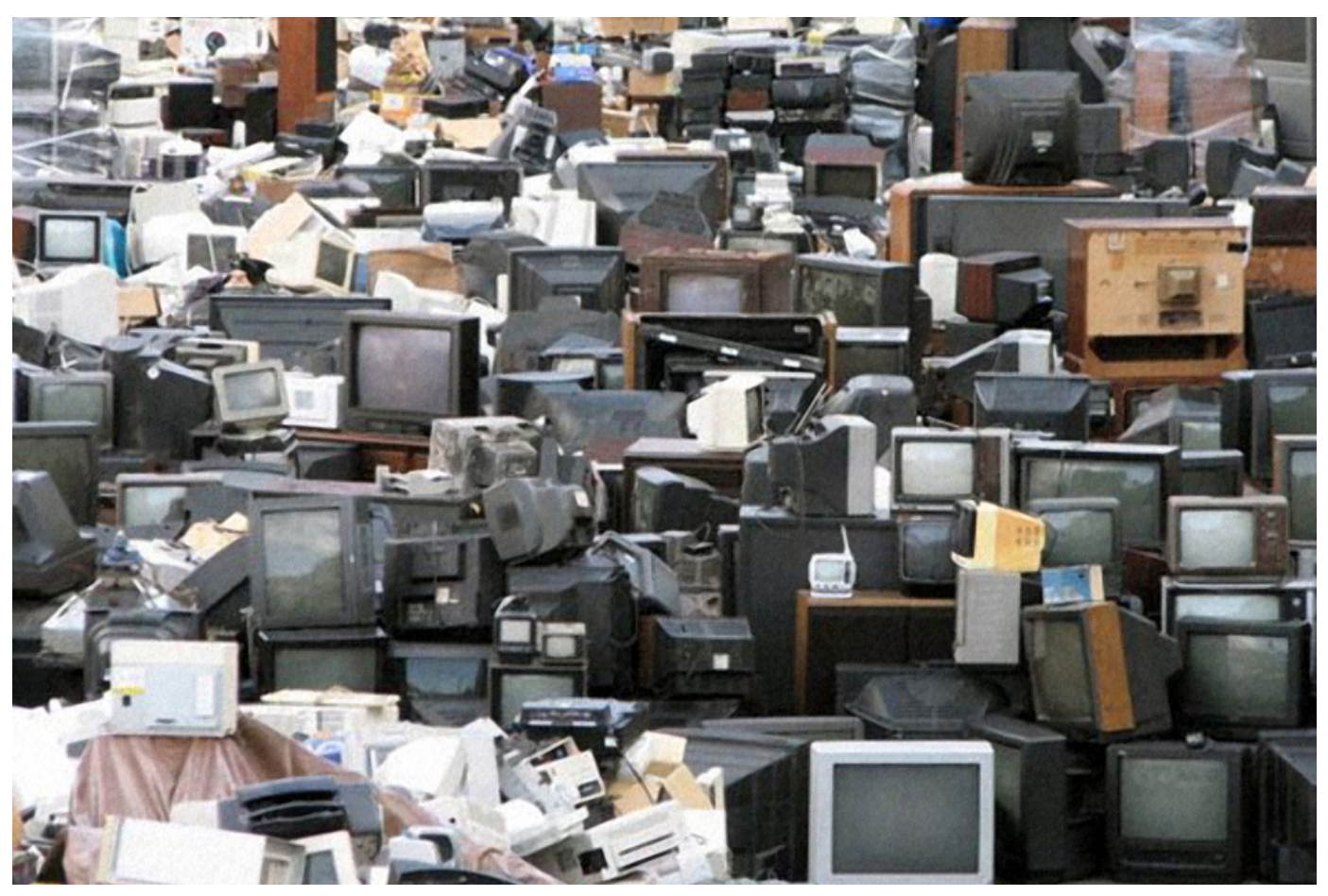

Figura 2: Imagens que ilustram locais de de descarte de lixo eletrônico. (Fonte: http://www.fragmaq.com.br/ blog/entenda-conceito-obsolescencia-programada-impactos-meio-ambiente/)

A pesquisa concluiu que, apesar da prática da obsolescência programada ser identificada nas empresas e produtos pelos consumidores, isso não muda sua vontade de ter sempre o produto mais atual em mãos, ou seja, os brasileiros naturalizaram a obsolescência, rebaixando a vida útil de um produto, pela obsolescência psicológica, e não pela obsolescência tecnológica ou funcional (ECHEGARAY, 2016).²

Voltando um pouco à citação inicial deste capítulo, ao pesquisar no Google o termo “obsolescência programada", obtemos imagens como a da figura 1 (acima). A imagem poderia ilustrar a descrição das montanhas de lixo que circundam a cidade fictícia de Leônia, mas também ajudam a ilustrar os números de geração de lixo eletrônico, assim como os de uso e fabricação de celulares, expostos anteriormente.

Nesse contexto, também o design é afetado pelas práticas de consumo relacionadas com a obsolescência programada, pois passa-se a procurar maneiras econômicas de produ-

${ }^{2}$ Obsolescência psicológica refere-se à aparência do produto, conforme item a da definição de obsolescência, descrita no início do capítulo, ou seja, pelo lançamento de um produto em uso com uma nova aparência que torna a anterior ultrapassada. A obsolescência tecnológica diz respeito aos itens b e c, ou seja, pela impossibilidade de conserto do produto ou pela tecnologia não funcionar mais, tornando lentos alguns dispositivos ou impossibilitando o uso do equipamento em alguns casos. As definições detalhadas dos tipos de obsolescência programada serão melhor exploradas no capítulo 2. 
ção, sem, contudo, preocupar-se com sua durabilidade, criando assim produtos cujo foco principal está na venda, e não no produto em si ou nas necessidades do consumidor. Whiteley (1993) afirma que passamos de um design focado no produto (product-lead) para um design focado no consumo (consumer-led ou market-led), que não surgiu espontaneamente, mas "como uma consequência quase inevitável de uma sociedade de consumo avançada e uma economia de mercado" (WHITELEY, 1993, p. 29). ${ }^{3}$

Dessa maneira, o design perde o que Papanek (1971) define como uma de suas principais funções: o design tem que ter significado, tem que ser significativo. "E significativo substitui expressões como belo, feio, fofo, diferenciado, glamoroso, realista, obscuro, abstrato e agradável de grande peso semântico [...] o modo de ação pelo qual um design cumpre esse propósito é sua função". Para ele, as funções que circundam um projeto de design são método, associação, estética, necessidade, uso e telesis (propósito de uso de processos naturais e sociais para obter objetivos sociais específicos). Vale destacar a ressalva que o autor faz na necessidade: "recentemente o design satisfaz apenas a desejos efêmeros, negligenciando, assim, necessidades genuínas."5

Em 2010, entrou em vigor no Brasil a Política Nacional de Resíduos Sólidos (PNRS), lei determina diretrizes para a gestão integrada e o gerenciamento de resíduos sólidos no país, responsabilizando produtores e consumidores pelos materiais produzidos e descartados. Merecem destaque algumas definições e determinações tratadas no capítulo 2 deste documento:

- destinação final ambientalmente adequada: reutilização, reciclagem, compostagem, recuperação e aproveitamento energético de modo a evitar danos ou riscos à saúde pública e à segurança e a minimizar os impactos ambientais;

- logística reversa: instrumento de desenvolvimento econômico e social caracterizado por um conjunto de ações, procedimentos e meios destinados a viabilizar a coleta e a restituição dos resíduos sólidos ao setor empresarial, para reaproveitamento, em seu ciclo ou em outros ciclos produtivos, ou outra destinação final ambientalmente adequada;

- padrões sustentáveis de produção e consumo: produção e consumo de bens e serviços de forma a atender as necessidades das atuais gerações e permitir melhores condições de vida, sem comprometer a qualidade ambiental e o atendimento das necessidades das gerações futuras;

\footnotetext{
3 “Consumer-led design has not emerged spontaneously from our 'enterprise culture', but has evolved as an almost inevitable consequence of an advanced consumer society and a market economy.” (WHITELEY, 1993, p. 29)

4 "Design must be meaningful. And meaningful replaces such semantically loaded expressions as beautiful, ugly, cute, distinguish, glamorous, realistic, obscure, abstract, and nice [...] the mode of action by which a design fulfills its purpose is its function.” (PAPANEK, 1971, p. 6)

${ }^{5}$ Much recent design has satisfied only evanescent wants and desires, while the genuine needs of man have often been neglected.” (PAPANEK, 1971, p. 15)
} 
- responsabilidade compartilhada pelo ciclo de vida dos produtos: conjunto de atribuições individualizadas e encadeadas dos fabricantes, importadores, distribuidores e comerciantes, dos consumidores e dos titulares dos serviços públicos de limpeza urbana e de manejo dos resíduos sólidos, para minimizar o volume de resíduos sólidos e rejeitos gerados, bem como para reduzir os impactos causados à saúde humana e à qualidade ambiental decorrentes do ciclo de vida dos produtos, nos termos desta Lei. (BRASIL, 2010)

Para contemplar a lei, o projeto do produto precisa ser pensado levando em consideração todas as etapas do seu ciclo de vida. Se as etapas iniciais do desenvolvimento de um produto estiverem alinhadas com a parte final de seu ciclo, mais fácil será cumprir as responsabilidades listadas na lei.

Papanek (2014) propunha já na década de 1970 produtos para a desmontagem ou produtos de uso compartilhado. O design para a desmontagem, como o próprio nome diz, parte da premissa de que um produto pode ser desmontado. Isso tem implicações no seu desenho inicial e na maneira como é fabricado, pois, para que isso aconteça, peças devem ser justapostas e parafusadas, ao invés de serem soldadas ou fundidas juntas, por exemplo. Para Papanek, são muitas as vantagens de produtos desenvolvidos com essa premissa: eliminando a linha de montagem do processo produtivo, há uma redução em seu custo; a participação do usuário na montagem do equipamento o torna mais consciente do processo construtivo, possibilitando seu conserto e fazendo também com que "se torne mais crítico na distinção entre o que é necessário e o que é superficial” (PAPANEK, 2014, p. 226); e o serviço de montagem pode ser contratado à parte, no caso de usuários que não se interessem nas características descritas anteriormente.

Para Manzini (2008), a etapa de desenvolvimento de produtos de design deve promover uma abordagem sistêmica que considere planejamento, produção execução, uso e descarte final.

O World Design Organization (WDO) - antigo ICSID — define design "como o estratégico processo de resolução de problemas que impulsiona a inovação, constrói o sucesso de um negócio e leva a uma melhor qualidade de vida através de produtos, sistemas, serviços e experiências inovadoras". ${ }^{6}$ Os designers "valorizam o impacto econômico, social e ambiental do seu trabalho e contribuem para a criação coletiva de uma melhor qualidade de vida."

\footnotetext{
6 "Industrial Design is a strategic problem-solving process that drives innovation, builds business success, and leads to a better quality of life through innovative products, systems, services, and experiences.” (WDO, 2016).

7 "They value the economic, social, and environmental impact of their work and their contribution towards co-creating a better quality of life." (WDO, 2016)
} 
No mesmo sentido, Braga introduz o livro O papel social do design gráfico com a ideia de que "em teoria, todo profissional consciente de seu papel ao exercer sua função social de maneira ética e de modo eficaz contribui para que a sociedade de que faz parte se desenvolva em harmonia” (BRAGA, 2011, p. 10-11). Para Redig não existe design que não seja social, uma vez que ele é sempre feito para a sociedade. "O que seria design social? Design comercial? Design comercial que não for dirigido às necessidades da sociedade não é design" (REDIG, 2001, p. 92-93). No mesmo sentido, Manzini acredita que "a qualidade de um determinado contexto é o resultado do cuidado de todas as pessoas que ali vivem" (MANZINI, 2008, p. 53).

Para Sevcenko, vivemos um período em que as inovações modificam o aparato tecnológico em períodos cada vez mais curtos, reconfigurando o universo de possibilidades e de expectativas, "tornando-o cada vez mais imprevisível, irresistível e incompreensível" (SEVCENKO, 2001, p. 16). Numa sociedade marcada pela velocidade (de transformações e de troca de informações), a questão que se coloca diz respeito às consequências que estas transformações acarretam para a sociedade e ao papel do design na melhoria deste cenário. "A crítica, portanto, é o modo de a sociedade dialogar com as inovações, ponderando sobre seu impacto, avaliando seus efeitos e perscrutando seus desdobramentos" (SEVCENKO, 2001, p. 17). No mesmo sentido, Forty (2007, p. 19) afirma que "a ideia de progresso, inclui todas as mudanças, tanto desejáveis como indesejáveis".

No meio industrial de hoje, a maioria das pesquisas não se preocupa em produzir para necessidades reais, mas em fazer com que as pessoas apenas desejem o que já foi produzido. Se a indústria em todos os países produzisse apenas para necessidades reais, o futuro seria brilhante. (PAPANEK, 1971, p. 333) ${ }^{8}$

Há na citação de Papanek um questionamento na maneira como os artefatos são produzidos e para quem. Enquadrando-se na lógica da obsolescência programada, há sempre o enfoque nas vendas e na concorrência, assim produtos se repetem pois não há pesquisas que apontem para necessidades reais, mas para necessidades induzidas. Nesse sentido, uma tomada de consciência dos consumidores ou uma legislação que imponha responsabilidades à indústria podem colaborar em uma mudança de cenário, porém também o design tem, ou deveria ter, papel fundamental nesta mudança.

\footnotetext{
8 "In industrial circles today, most major research concerns itself not with producing for actual needs, but rather propagandizes people to only desire what has been produced. If industry in all countries were to produce only what is needed, the future would look bright indeed.” (PAPANEK, 1971, p. 333)
} 
Partindo das definições de obsolescência programada elaboradas por Packard (1965), Papanek (1971) e Slade (2007) e considerando o design como uma atividade engajada intrinsecamente nas questões sociais - como exemplificado na definição da WDO, nas palavras de Papanek (1971), Whiteley (1993), Manzini (2008), Braga (2011) e Redig (2011) - , esta pesquisa procurou definir parâmetros conceituais que permitissem identificar manifestações de obsolescência programada presentes no mercado brasileiro de produtos de larga escala, traçando um panorama do fenômeno no contexto atual, identificando produtos e propondo uma reflexão sobre sua relação com o design e suas possíveis contribuições para a redução dos danos causados por ela.

\subsection{Questão da pesquisa}

Esta dissertação se desenvolveu a partir da pergunta: Quais manifestações de obsolescência programada podem ser identificadas por meio de um estudo qualitativo exploratório no mercado brasileiro de produtos de larga escala com base nos conceitos de Vance Packard (1965), Victor Papanek (1971) e Giles Slade (2007) e que relação pode ser estabelecida entre o fenômeno estudado e o design a partir da percepção dos consumidores e dos designers envolvidos com a produção industrial no país?

\subsection{Objetivos da pesquisa}

O objetivo geral da pesquisa foi o de identificar os tipos de obsolescência programada existentes no mercado brasileiro no que diz respeito aos diferentes tipos de obsolescência, bem como aos produtos identificados com cada tipo, para então discutir sua relação com o design. Sendo assim, os objetivos específicos da pesquisa são:

a) Definir os parâmetros conceituais para a identificação dos tipos de obsolescência programada.

b) Identificar as práticas de consumo relacionadas com a obsolescência programada, que permitem inferir sua existência.

c) Identificar as manifestações de obsolescência programada no mercado, de acordo com os parâmetros conceituais definidos e as práticas de consumo pesquisadas.

d) Identificar os produtos relacionados a cada um dos tipos de obsolescência programada, listando os produtos mais citados.

e) Averiguar o conhecimento dos consumidores do fenômeno, dando especial atenção ao fato de identificarem essa prática no seu cotidiano, mais do que o conhecimento do nome que se dá a ela. 
f) Investigar de que maneira o design atua em relação ao fenômeno estudado.

g) Investigar de que maneira o design pode contribuir para a melhora das consequências da obsolescência programada.

\subsection{Definição dos principais conceitos utilizados na pesquisa}

Como apontado por Valquíria Padilha (2016), a obsolescência programada se enquadra dentro de uma das estratégias para a manutenção do sistema capitalista vigente, que se apoia num crescimento constante, do qual fazem parte também o conceito de excesso, de consumo de massa e de publicidade:

O capitalismo precisou desenvolver o que chamamos de "sociedade de consumo", em que as necessidades e os desejos são costurados numa trama confusa e complexa. Fica cada dia mais difícil escrevermos uma lista de coisas essenciais para nossas vidas. Há 80 anos era mais fácil. Precisamos de comida tanto quanto de um celular? Que tipo de comida? Tudo se mistura em nossa mente. Isso se agravou a partir dos anos 1930, com o desenvolvimento do fordismo, sistema de produção e de consumo de massa. A intenção da sociedade de consumo é essa mesma: confundir-nos, nos fazer crer que não podemos viver sem o último celular lançado, o último carro com GPS (Global Positioning System), a roupa que a atriz famosa usa na novela, o notebook ultrafino que se converte em tablet e por aí vai. [...] Juntos, publicidade e obsolescência programada são combustíveis essenciais para manter funcionando o ciclo de produção-consumo-mais produção-mais consumo de nossa atual sociedade capitalista. Podemos acrescentar, ainda, para formar um tripé, o sistema de créditos, que estimula a compra parcelada com base na propagação da lógica do "satisfaça agora os teus desejos e pague depois”. (PADILHA, 2016, p. 46-47)

O conceito de obsolescência programada e suas diferentes manifestações baseia-se nas definições de Packard (1965), Papanek (1971) e Slade (2007). O tema desta pesquisa supõe o estabelecimento de uma data de morte do produto no momento de sua fabricação, informação de difícil acesso e que não faz parte dos objetivos deste trabalho. Por essa razão, optou-se por abordar o conceito de práticas de consumo, pois, por meio delas, é possível aferir a existência da obsolescência programada. $\mathrm{O}$ conceito de práticas de consumo diz respeito à vida prática das pessoas, na maneira como se relacionam com os produtos consumidos: se há o hábito de mandar consertar ao invés de trocar um produto; se nessa busca pela manutenção dos equipamentos há dificuldade de encontrá-la e realizá-la ou se isso é mais oneroso do que a compra de um novo equipamento; se as compras são realizadas a crédito ou à vista, entre outras que serão melhor detalhadas no capítulo 2 desta dissertação.

É importante fazer aqui uma pequena distinção entre o efêmero e o descartável. A ob- 
solescência programada, como veremos no capítulo 2, precisou da ideia de descartável para se desenvolver, porém nem tudo que é descartável se enquadra no fenômeno estudado. Mas foi preciso que a ideia do descartável fosse introduzida no cotidiano das pessoas para tornar obsoletos (e muitas vezes descartáveis) produtos antes entendidos como duráveis. Procurou-se tratar de produtos que não são originalmente descartáveis, como copos plásticos ou embalagens - e que muitas vezes são associados com o fenômeno estudado - , mas que ganham características descartáveis por seu uso. Um celular não é necessariamente feito para ser jogado fora após um curto período de uso, porém, ao ser descartado dessa maneira com frequência, ele pode ser considerado descartável. Em outras palavras, foi preciso naturalizar a ideia de descartável - entre outras - para que as pessoas fossem capazes de trocar seus carros não porque estivessem quebrados, mas porque estavam fora de moda. A esta pesquisa interessou somente produtos diretamente relacionados à obsolescência programada, portanto, não serão estudados os produtos naturalmente descartáveis ou que tenham impacto na geração de lixo, como embalagens.

Ao falar de práticas de consumo e de consumo de massa, fala-se do consumo repetitivo, conceito muito próximo à obsolescência programada e que leva ao consumismo, conceito que será abordado também de maneira breve usando como base teórica as ideias de Bauman (2008).

Para entrarmos no discurso do design, será também tratado o aspecto de projeto de produto em design relacionado com a obsolescência dos artefatos, tendo como principal base teórica autores como Manzini (2008) e Papanek (1971). Procurou-se tratar de práticas de projeto que contemplem um ciclo completo dos produtos, tais como logística reversa e upcycling. ${ }^{9}$ Muitos deles contemplam também requisitos de produtos sustentáveis, porém não é intenção desta pesquisa tratar o tema da sustentabilidade em profundidade.

${ }^{9}$ Upcycling trata da reutilização de resíduos sólidos, ou materiais descartados, em sua forma original e transformando-os em novos produtos. 


\subsection{Delimitações da pesquisa}

Conforme exposto anteriormente, as delimitações teóricas da pesquisa estão restritas às práticas de consumo, não cabendo no recorte da pesquisa temas pertinentes também relacionados à obsolescência programada, tais como sustentabilidade, reciclagem e o conceito de descartável.

Ao tratarmos de projeto de produto, o foco da pesquisa está, de novo, em compreender as consequências da obsolescência programada, assim como exemplos de bom uso dos recursos naturais e da não geração de resíduos.

Há uma delimitação territorial na pesquisa, que se propunha inicialmente a tratar do mercado brasileiro. Porém, devido à falta de recursos pessoais e de tempo hábil, as respostas recebidas pelo questionário acabaram se concentrando no mercado paulista, que, contudo, é o maior mercado consumidor do Brasil, dado relevante para pesquisa.

\subsection{Justificativas da pesquisa}

Esta pesquisa decorre diretamente do estudo, iniciado na graduação da pesquisadora, sobre a substituição da mídia vinil pela mídia CD. Essa evolução tecnológica, que fez com que muitas pessoas jogassem fora sua coleção de vinis para iniciar uma nova coleção de CDs, foi o primeiro contato com a obsolescência programada e a motivação para a criação de uma vitrola como projeto de conclusão de curso de desenho industrial com habilitação em projeto de produto.

Um interesse que só se intensificou com a prática de trabalho como designer gráfica, principalmente por conviver no campo com muito poucas iniciativas que dialoguem de maneira contrária às práticas de consumo relacionadas à obsolescência programada. Ainda que seja possível perceber iniciativas que caminhem no sentido contrário à lógica da obsolescência programada, na prática de trabalho, proposições nesse sentido nem sempre são bem-vindas, por sugerirem um modelo de trabalho que muitas vezes não condiz com o que já está estabelecido.

\footnotetext{
A aceleração das inovações tecnológicas se dá agora, numa escala multiplicativa, uma autêntica reação em cadeia, de modo que, em curtos intervalos de tempo, o conjunto do aparato tecnológico vigente passa por saltos qualitativos em que a ampliação, a condensação e a miniaturização de seus potenciais reconfiguram completamente o universo de possibilidades e expectativas tornando-o cada vez mais imprevisível, irresistível e incompreensível. Sendo assim, sentindonos incapazes de prever, resistir ou entender o rumo que as coisas tomam, tendemos a adotar a tradicional estratégia de relaxar e gozar. Deixamos para pensar nos prejuízos depois, quando
} 
pudermos. Mas o problema é exatamente esse; no ritmo em que as mudanças ocorrem, provavelmente nunca teremos tempo para refletir, nem mesmo para reconhecer o momento em que já for tarde demais. A intenção deste texto é tentar contribuir para que isso não ocorra, ou seja, para que, aturdidos por esse efeito desorientador de aceleração extrema, não nos sintamos dispostos a ceder, desistir e nos conformar com o que vier. [...] A crítica, portanto, é o modo de a sociedade dialogar com as inovações, ponderando sobre seu impacto, avaliando seus efeitos e perscrutando seus desdobramentos. (SEVECENKO, 2001, p. 16-17)

De acordo com Sevcenko, a característica principal da nossa sociedade atual é a velocidade com que novas tecnologias são inventadas. Forty (2007) afirma que todo progresso traz consigo mudanças desejáveis e indesejáveis. Estamos diante de um momento de mudança, pois a maneira como artefatos são produzidos e comercializados desde a implementação da obsolescência programada estão colocando a sociedade frente a uma limitação ambiental no que diz respeito ao esgotamento dos recursos e um crescimento alarmante na geração de lixo eletrônico. Frente a essa limitação, modelos de consumo e fabricação são questionados. O design é uma importante ferramenta para modificar este cenário uma vez que, como enfatiza Forty (2007), quase todos os objetos que usamos, a maioria das roupas que vestimos e muitos dos nossos alimentos foram desenhados.

Em torno da busca por um mundo sustentável, o design e sua função social são extremamente importantes de ser avaliados e revistos, pois têm relação direta com o consumismo e o impacto ambiental negativo de extração incessante e acelerada de recursos naturais. Como destacou Sevcenko, o “já é tarde” pode estar chegando, e a sociedade precisa tomar consciência das consequências negativas de práticas de consumo e descarte sem limites e romper este ciclo vicioso.

A quantidade de artigos sobre a obsolescência programada nos periódicos brasileiros é bastante reduzida, portanto trata-se de um tema a ser explorado pelas comunidades acadêmicas. Nas buscas realizadas nos bancos de dissertações e teses das principais universidades brasileiras,${ }^{10}$ além dos periódicos da Capes, foi encontrado um número reduzido de pesquisas relacionadas ao tema, sendo encontrada apenas uma pesquisa de mestrado sobre o tema na área de design.

Por esta razão, não se pretende com esta pesquisa esgotar o tema, mas lançar luz a ele de maneira ampla, gerando dados e materiais que possam ser explorados por pesquisas futuras.

${ }^{10}$ Os termos "obsolescência programada" e "obsolescência planejada" foram pesquisados nos periódicos da Capes e nos bancos de dissertações e teses das seguintes universidades: Unesp, Unicamp, FEA, UFRGS, UFPR, UFPE e Unisinos. 


\subsection{Estrutura da dissertação}

A dissertação é composta de cinco capítulos: introdução, referencial teórico, método, resultados e considerações finais.

O presente capítulo 1, denominado "Introdução", como visto, apresentou a caracterização geral, questão e objetivos da pesquisa, as definições dos principais conceitos abordados, justificativa e delimitações para o seu desenvolvimento.

O "Referencial teórico", apresentado no capítulo 2, trata das principais definições de obsolescência programada, um breve histórico e temas diretamente relacionados a ela, como práticas de consumo e consumismo. Neste capítulo também são expostas iniciativas que caminham na direção oposta da obsolescência programada, ilustrando brevemente o momento atual, bem como o papel do design nos diferentes contextos.

O capítulo 3, denominado "Método de pesquisa", exibe a caracterização geral da pesquisa, assim como os procedimentos para coleta tratamento dos dados coletados com o questionário e com as entrevistas realizadas.

O capítulo 4, denominado "Resultados" apresenta os dados levantados pelo questionário no que diz respeito às práticas de consumo identificadas no mercado brasileiro, os produtos mais citados, a percepção do fenômeno por parte dos consumidores. Também mostra o cruzamento dos dados coletados com o questionário e os levantados na revisão da literatura, assim como o resultado das entrevistas realizadas e da sondagem feita na rede social Facebook a respeito do tema, propondo uma reflexão sobre a relação do design com a obsolescência programada.

O capítulo 5, denominado "Considerações finais", propõe uma reflexão sobre o problema geral da pesquisa, sugerindo caminhos para futuras pesquisa nesse tema ainda pouco documentado. 



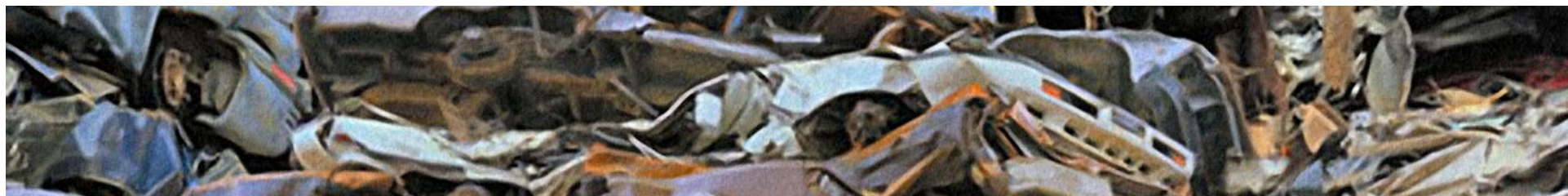
- n-an. $35 .-2020$

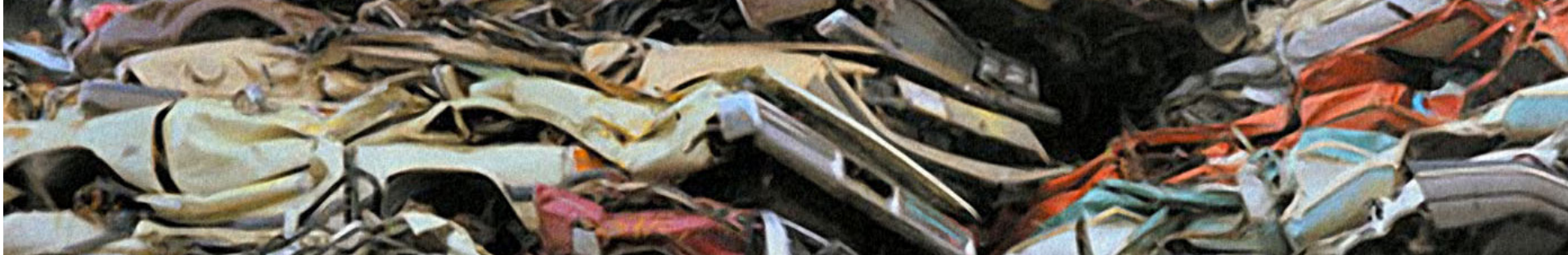
Lnt 1 - 12 ?

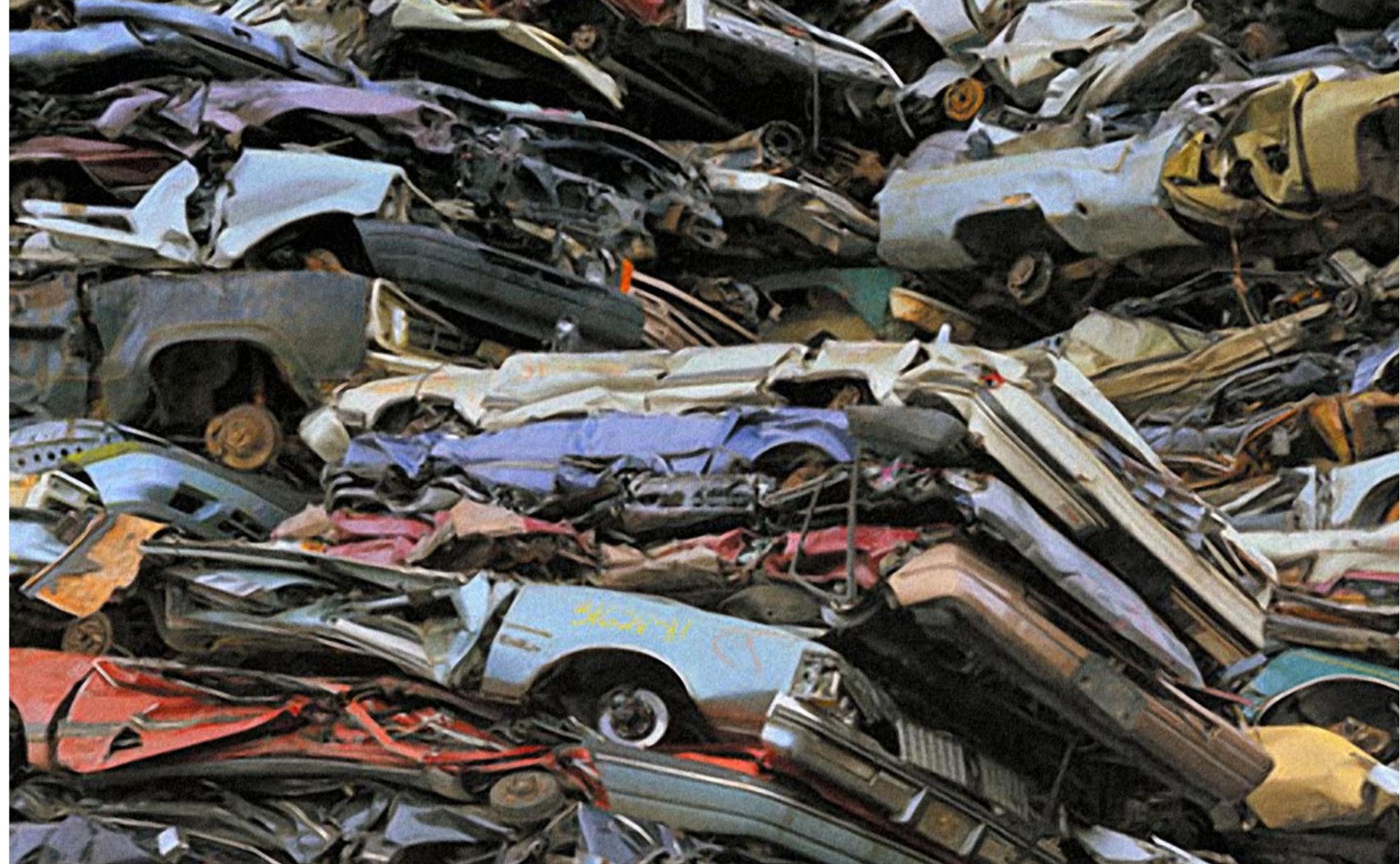

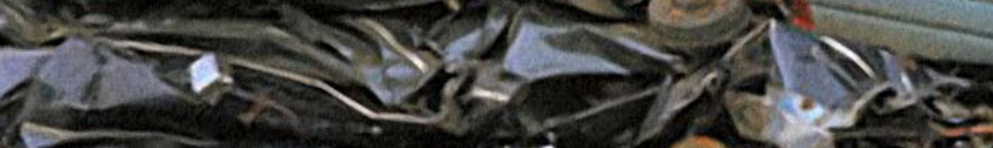

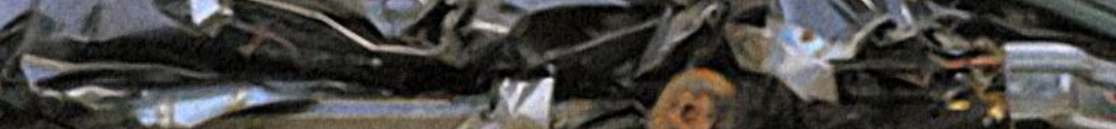




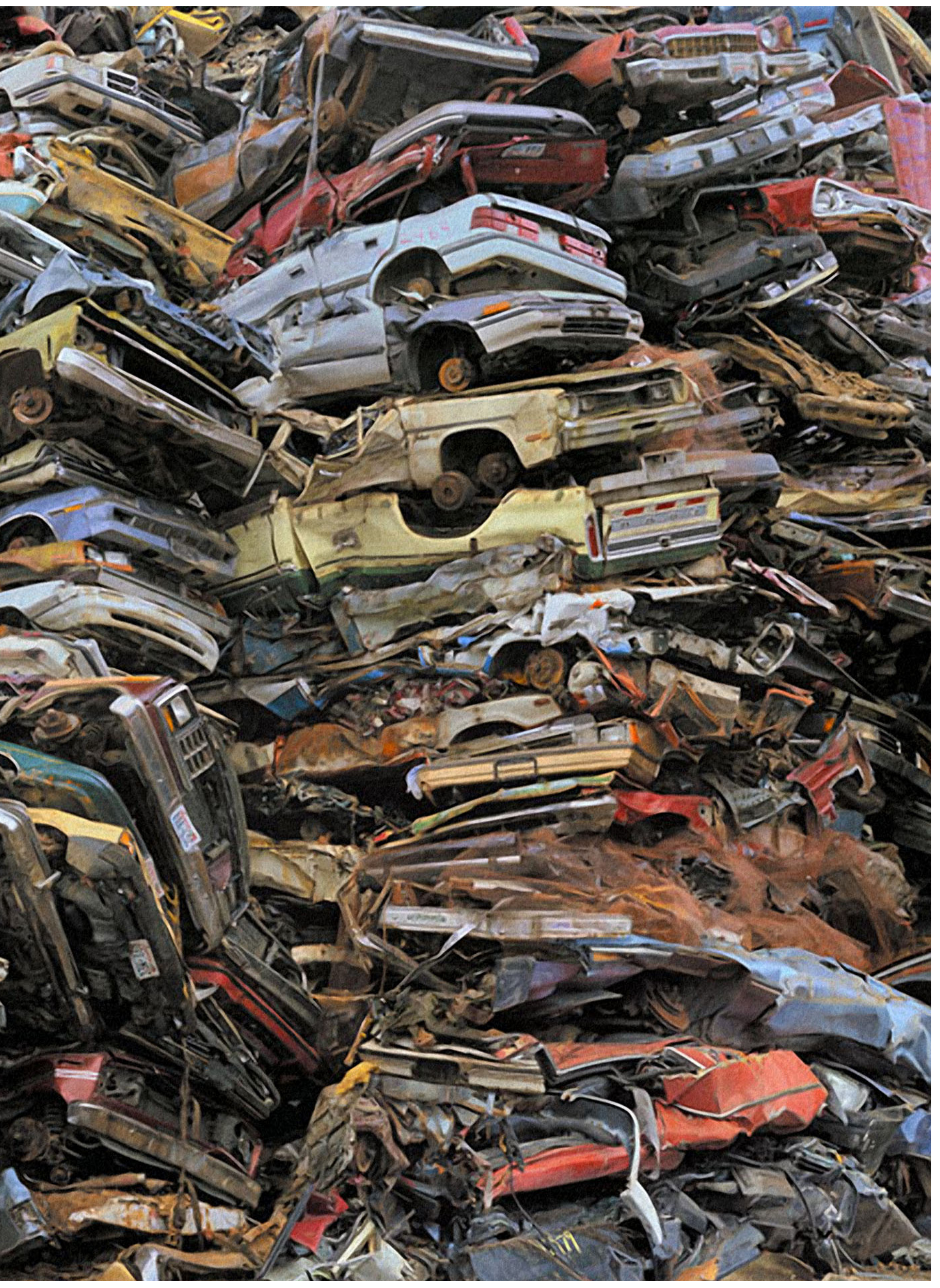




\section{$<$ na página anterior}

Figura 3. Crushed cars \#2, Tacoma 2004.

(Fonte: Ensaio fotográfico de Chris Jordan Intolerable Beauty: Portraits of American Mass Consumption 2003 - 2005 Disponivel em http://www.chrisjordan.com/gallery/intolerable/\#crushed\%20cars\%202\%20\%2044x62) 


\section{2 \\ Referencial teórico}

O termo obsolescência é empregado desde o final do século XIX, sinalizando a troca de ferro por aço em diversos utilitários (SLADE, 2007), e a própria chegada da energia elétrica ocasionou uma grande troca de equipamentos que pode ser classificada como um dos primeiros exemplos de obsolescência tecnológica, ainda que não tenha sido programada.

"As inovações técnicas não acontecem espontaneamente, mas apenas quando alguém vê que há algo a ganhar com elas, e são aplicadas somente quando é interesse de alguém fazê-lo" (FORTY, 2007, p. 248). A luz foi inventada para a iluminação noturna das ruas, mas sua produção era contínua e tinha muito pouco uso diurno. Para aumentar seu consumo também durante o dia, deveria ser usada nas casas, pelo uso de aparelhos elétricos. Havia três empecilhos para a adoção da luz elétrica nas casas, segundo Forty (2007): seu custo para os consumidores era inicialmente muito alto (porém, se tornaria mais barato com o aumento da demanda), sua distribuição e ligação eram onerosas para a indústria de fornecimento e, por último, as pessoas sentiam medo da eletricidade - "nos Estados Unidos noticiou-se nos anos 1930 o caso de uma mulher que se recusava a usar o fogão elétrico moderno dizendo que era 'mal-assombrado demais' e preferia seu fogão a lenha" (FORTY, 2007, p. 260). 
Dessa maneira, segundo Forty (2007), novas demandas de consumo foram criadas para que ela fosse consumida também durante o dia: produtos elétricos foram inventados para substituir seus antecessores a gás, e o design, juntamente com a propaganda, deveria então contribuir em fazer as pessoas "precisarem" dela e de produtos elétricos que, até então (1895), viviam muito bem sem.

O alto custo da eletricidade e o fato de ela não ser mais eficiente do que o gás para cozinhar e aquecer significavam que os consumidores que a escolhiam deviam estar sob a influência de outras razões, além do valor do dinheiro. Uma dessas razões era que se dizia que a eletricidade era uma fonte de energia progressista e libertadora, com um potencial futuro ilimitado. Em última análise, dar ou não crédito a essas afirmações dependia do que as pessoas pensavam dos aparelhos que utilizavam a energia. $O$ futuro da eletricidade, portanto, dependia da melhoria do design dos eletrodomésticos. (FORTY, 2007, p. 260)

Aquecedores, chaleiras, torradeiras, máquinas de lavar pratos, ferros de passar roupa, aspiradores de pó e batedeiras, antes manuais ou a gás, deram lugar a equipamentos elétricos comprados e foram os primeiros produtos a serem comprados em massa na Inglaterra, nos anos 1920.

O termo obsolescência programada foi divulgado pela primeira vez numa versão impressa por um corretor imobiliário de Nova York, Bernard London, que em 1932 escreveu um panfleto intitulado "Ending the depression through planned obsolescence" ${ }_{11}^{11}$ no qual propunha que um alto volume de vendas ajudasse os Estados Unidos a sair da crise. Para tanto, London acreditava que o governo deveria, por meio de pesquisas dos materiais envolvidos na produção dos bens de consumo, definir um prazo "legal" da duração dos produtos; deveria também obrigar algumas empresas a pegar de volta os objetos descartados ou, ainda, gerenciar locais onde artefatos, como móveis, pudessem ser descartados, ajudando, com isso, o pagamento da compra de novos produtos (SLADE, 2007, p. 73-75).

Na imprensa, a primeira vez que o termo obsolescência programada surgiu foi no artigo do industrial americano Brooks Stevens intitulado "The desire of the new", ${ }^{12}$ publicado em 1953. O artigo ilustra essa mudança no comportamento das pessoas, pois para Stevens o importante era a obsolescência psicológica, e não a data de morte de um produto, ou seja, importava o tempo para se enjoar de algo, não o tempo para que ele quebrasse. Seu artigo ajudou a desenvolver esse "desejo por algo um pouco mais novo, um pouco melhor e um pouco mais moderno do que o necessário" (SLADE, 2007, p. 153) 13 $^{13}$

\footnotetext{
${ }^{11}$ Numa tradução livre, "acabar com a depressão (ou crise) por meio da obsolescência programada”,

${ }^{12}$ Numa tradução livre, "o desejo do novo",

13 "Planned obsolescence for Stevens, was simply psychological obsolescence, not product death dating. It grew out of 'the desire to own something a little newer, a little better, a little sooner than its necessary”'. (SLADE, 2007, p. 153)
} 
Porém, a criação e a aplicação do conceito de obsolescência programada na indústria é anterior e atribuída a Alfred Sloan, presidente da General Motors na década de 1920. Segundo Slade (2007), a implementação desse conceito se deu graças à concorrência entre Ford e GM, líderes de mercado do segmento de automóveis da época, como será visto a seguir.

São três os principais tipos de obsolescência descritos na revisão da literatura, como será visto de maneira mais detalhada no tópico "Definições de obsolescência programada". Slade os divide como etapas de seu desenvolvimento (SLADE, 2007, p. 4), sendo a primeira etapa iniciada no final do século XIX com o surgimento da obsolescência tecnológica ("obsolescence due to technological innovation"); a segunda etapa desenvolvida na década de 1920 com a obsolescência psicológica (estilística ou de desejabilidade); e por fim a obsolescência artificial, passando a vigorar desde meados de 1930 e na qual componentes passaram a ser acrescentados aos produtos para que eles tivessem seu tempo de vida reduzido. Apesar de Slade assumir que o primeiro tipo de obsolescência identificada foi a tecnológica, não é possível dizer que ela foi programada. De fato, houve a primeira grande troca de equipamentos, graças a chegada de uma nova tecnologia (a energia elétrica), e os esforços necessários para que essa grande troca ocorresse se assemelham aos esforços feitos a partir da década de 1920, com o desdobramento da obsolescência psicológica. Porém, como veremos a seguir, a obsolescência tecnológica, como a definimos hoje, apesar de ter semelhanças, possui características diferentes do primeiro caso descrito.

\subsection{Breve histórico da obsolescência programada}

Segundo Lippincott (1947), os EUA aprenderam duas grandes lições com as Guerras Mundiais: sua grande capacidade de produção, que sozinha quase se igualou à produção industrial do resto do mundo combinado no período da Segunda Guerra Mundial, e o poder da pesquisa, também fortalecida nesse período.

Nesse contexto, e graças às lições aprendidas pelos EUA, a obsolescência programada surge com a intenção de salvar a economia americana que, depois da grande crise de 1929, assim como muitos mercados mundiais, tinha de um lado uma grande capacidade industrial e de outro um povo sem poder de compra. Os estoques das lojas eram grandes e era preciso aumentar o consumo, "o meio de acabar com o excesso de comida era produzir comilões” (PACKARD, 1965, p. 27). Vender mais significava também gerar mais empregos, pois levaria a um aumento maior da produção. 
No caso dos eletrodomésticos, citados no início deste capítulo, uma nova tecnologia nos produtos tornou obsoleta a anterior. Porém, a prática de deliberadamente encorajar a obsolescência do produto surgiu efetivamente com a indústria automobilística pouco menos de uma década depois, valendo-se da obsolescência psicológica. Adaptou-se aos carros o conceito original da moda e seu nicho de mercado, em que coleções são lançadas a cada estação, pois o crescimento em suas vendas não poderia depender somente dos avanços tecnológicos, por serem caros e demorados.

É interessante observar a mudança no pensamento de negócio que se deu naquela época e que propiciou o surgimento não só do termo, mas também da prática da obsolescência programada. Slade reproduz em seu livro o trecho de uma entrevista com Henry Ford - então presidente da Ford - no início da década de 1920 em que ele declara que, ainda que soubesse que muitas empresas considerassem boa prática, e não uma falta de ética, a implementação de pequenas mudanças no design dos carros para aumentar suas vendas, seu pensamento de negócio era precisamente contrário, e ele não poderia conceber servir ao consumidor de outra maneira que não fornecendo algo que durasse para sempre (SLADE, 2007, p. 32).

No mesmo sentido, Packard afirma, no que diz respeito aos carros, que "toda mudança, seja aparentemente sensata ou aparentemente insensata, ajuda a criar obsolescência. O que importa é a mudança”" (PACKARD, 1965, p. 82).

Nessa época, Alfred Sloan estava à frente da GM e pregava que o dinamismo do capitalismo tornava a obsolescência tecnológica quase inevitável (SLADE, 2007, p. 33). Para concorrer com a Ford, então líder de mercado, desenvolveu uma maneira de criar cinco modelos diferentes de carro no mesmo formato de chassi, ou seja, por meio de mudanças que não demandavam grandes investimentos em seu maquinário, mas apenas colocavam "adereços" nos carros, a GM conseguiu superar as vendas de sua maior concorrente. Os detalhes, quase sempre só estéticos, tornavam os carros mais atrativos. As mudanças foram implementadas graças a pesquisas de mercado realizadas pela GM que apontaram para uma diversificação de seus compradores, atraindo também o público feminino, por exemplo. Dessa maneira, o que ficou conhecido como o modelo anual de carro passou a ser uma prática na indústria automotiva, na qual pequenas mudanças anuais nos modelos tornavam antiquados os modelos anteriores, atraindo novos compradores.

Segundo o documentário The man who made us spend (2014), Sloan percebeu que poderia segmentar o mercado apresentando opções de cor e de modelos de carro, em contraposição à Ford, que era líder de mercado com apenas um, o Model T, cujo slogan era "você pode ter ele em qualquer cor, desde que seja preto". ${ }^{14}$

14 "You can have any color, as long as it's black." (THE MAN, 2014) 


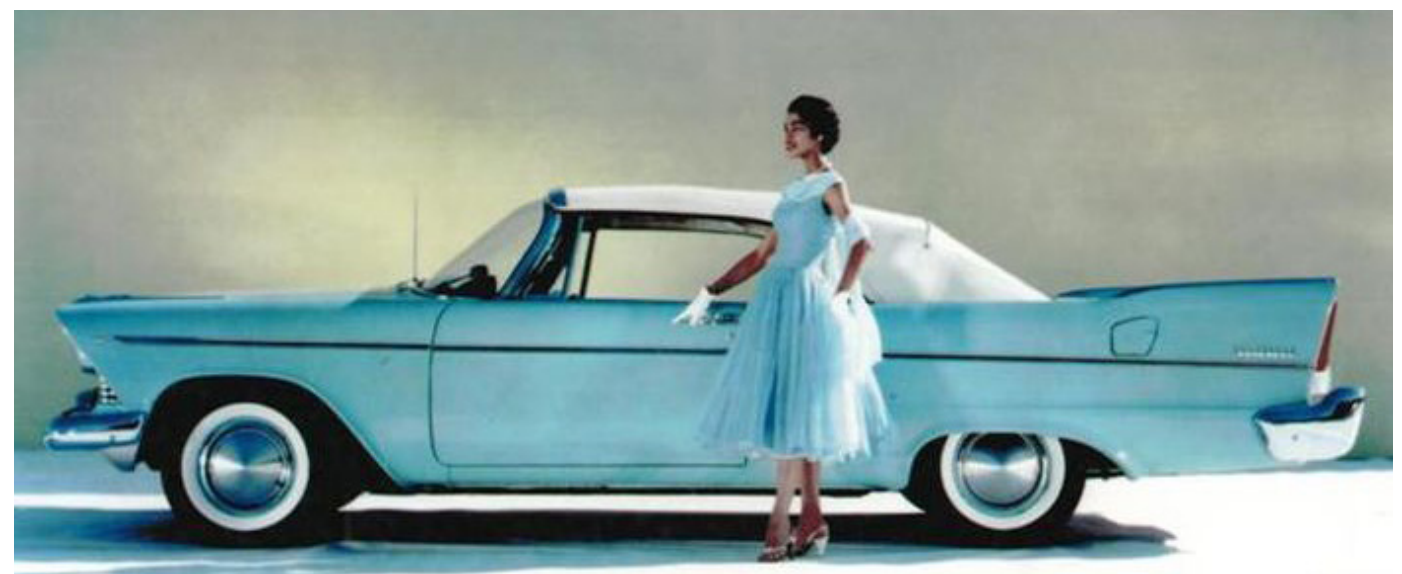

4
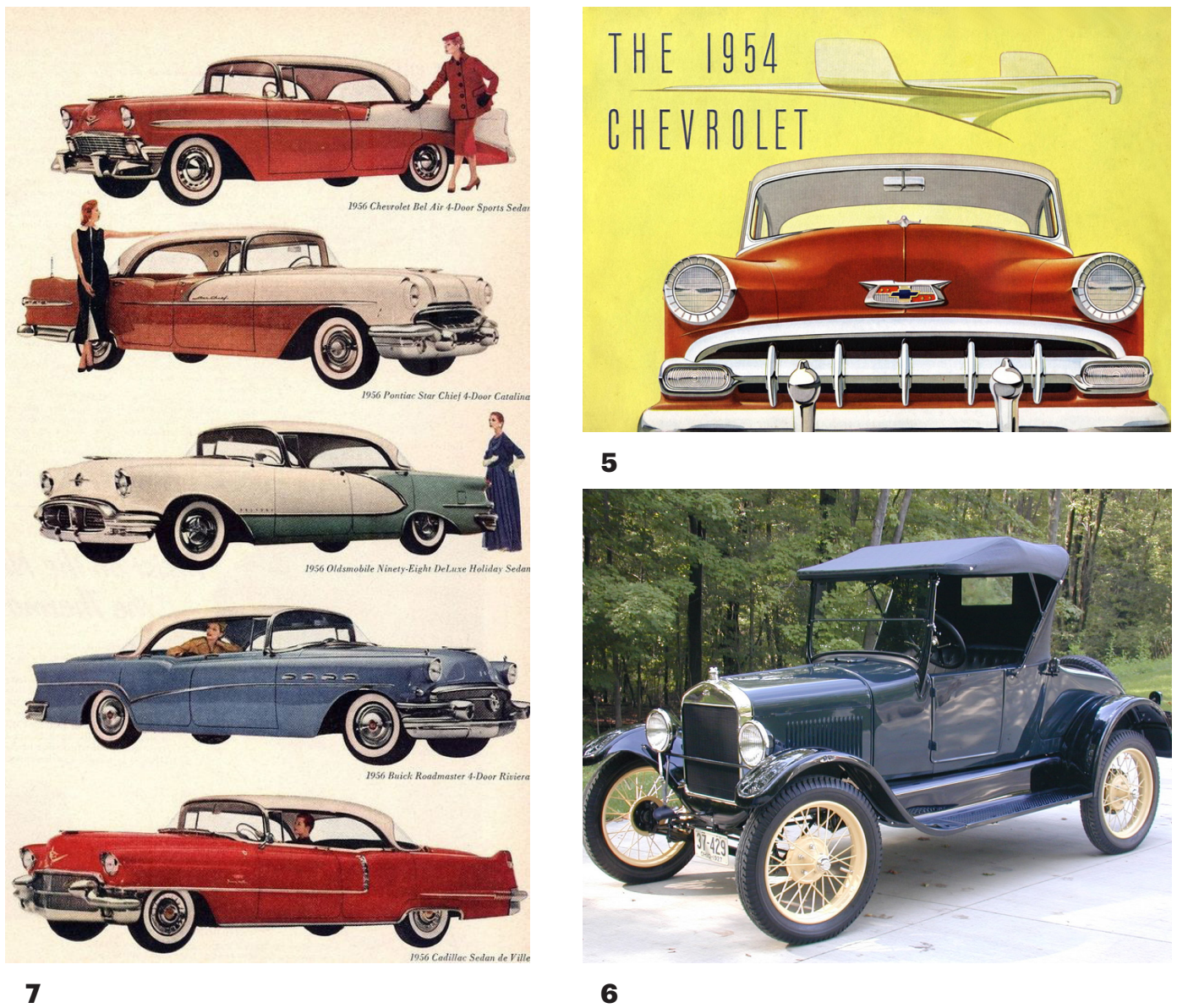

5

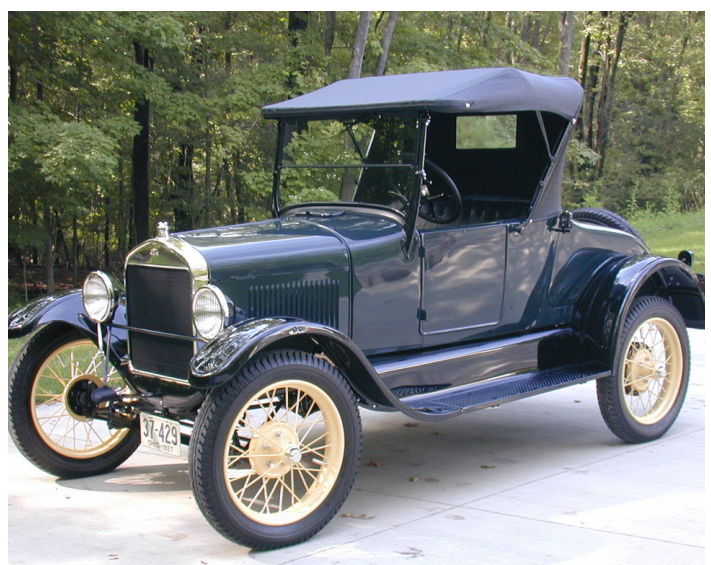

6

Figura 4: Carro da Chrysler em 1957, motrando a roupa que combina com o carro.

(Fonte: https://www.hemmings.com/blog/2014/02/15/four-links-larry-watsons-rainbow-cars-prop-car-african-americans-in-auto-advertising-geobaker/)

Figura 5: Anúncio Chevrolet de 1957, associação do desenho dos carros com os aviões. (Fonte: http://www.carrosyclasicos.com/historia/item/525-chevrolet-1955,-casi-60-a\%C3\%B1os-de-historia)

Figura 6: O Model T da Ford.

(Fonte: https://carrosantigos.wordpress.com/2008/o7/25/100-anos-do-ford-modelo-t/)

Figura 7: Modelos de carro da GM na década de 1956. F

(Fonte: http://omnibusofspeed.tumblr.com/post/71571048768/theniftyfifties-general-motors-1956-models) 
Um exemplo dessas modificações de estilo sem justificativa funcional é o GM Cadillac LaSalle de 1927, que tinha a distância entre os eixos maior do que a dos carros da época e um rebaixamento do seu chassi, características que, além de não ter justificativa mecânica, comprometia sua ergonomia - tanto para entrar e sair do veículo, como para dirigi-lo - , mas o fez um campeão de vendas por parecer forte e veloz. Outro bom exemplo é o dos famosos carros com rabo de peixe, que faziam menção ao desenho dos aviões, símbolo da modernidade na época em que foram lançados, no final da década de 1930 e início da década de 1940.

O que aconteceu, aparentemente, é que se passou a valorizar a estética dos produtos e a ideia de estilo foi então estendida a muitos artigos [...] As pessoas compram um carro novo, não porque o velho está ruim, mas porque não é mais moderno e/ou não satisfaz mais o seu orgulho [...] Não há como fazer com que as pessoas substituam um carro novo que funciona bem por um carro velho que funciona bem, a menos que alguma qualidade seja adicionada. A nova qualidade deve ser emprestada do reino do bom gosto: linhas mais inteligentes, novo design, cores mais bonitas, estofos mais luxuosos, mais arte ou, pelo menos, mais estilo. (SLADE, 2007, p. 49-50 $)^{15}$

À semelhança de seu modelo - a moda - , passou a ser adotado na indústria automobilística o modelo anual, que quando lançado fazia parecer velho seu antecessor. “"Novo' tornou-se palavra chave quando os produtores procuravam fazer os proprietários de automóveis sentirem-se antiquados com qualquer veículo com mais de dois anos de idade" (PACKARD, 1965, p. 74).

Boa parte do mundo estava então em transformação conforme novas coisas substituíam as velhas, e muitos valores antigos estavam entrando em conflito com novos - talvez isso ajude a explicar a razão pela qual a obsolescência tornou-se um conceito tão expressivo e poderoso no final da década de 1920 e década de 1930. (SLADE, 2007, p. 62) ${ }^{16}$

No mesmo sentido, segundo Lippincott, “o século vinte é o primeiro período caracterizado por uma aceitação de mudanças no consumo de massas de maneira mais natural e desejável”. Até então, segundo o autor, de maneira geral a preocupação principal da população era se preparar para a eternidade, não melhorar o cotidiano. O provér-

\footnotetext{
15 "What has happened, apparently, is that many more people have become conscious of style and the style idea has been extended to many more articles [...] People buy a new car, not because the old one is worn out, but because it is no longer modern. It does not satisfy their pride [...] you cannot make people substitute a new car that runs well for an old car that runs well unless it has some added quality. The new quality must be borrowed from the realms of good taste, smarter lines, new design, better color, more luxurious upholstery, more art, or at least more taste.” (SLADE, 2007, p. 49-50)

16 So much of the world was then in transition as new things constantly replaced old ones, and so many old values were coming into conflict with new ones - perhaps this helps explain why "obsolescence" became such an expressive and powerful concept during the late 1920 s and 1930s. (SLADE, 2007, p. 62)
} 
bio, "nada é certo, exceto a morte e os impostos", poderia ser substituído na década de 1940 - e ainda hoje - por "nada é certo, exceto a morte, os impostos e a mudança" (LIPPINCOTT, 1947, p. 8).

Datam desta época também invenções como lâmina de barbear, preservativo, curativo adesivo, absorvente e tampão higiênico e lenços de papel, que reforçavam a ideia de descartável e habituavam cada vez mais as pessoas ao consumo repetitivo e à "aceitação cultural da ética de jogar tudo fora, um antecessor indispensável à obsolescência programada". ${ }^{17}$ Os produtos listados eram muitas vezes vendidos por meio de um apelo à higiene ou à saúde das pessoas (SLADE, 2007, p. 24).

Packard (1965, p. 40) descreve algumas propagandas que ilustravam o descarte constante: "bifes e outras carnes apareceram em frigideiras de alumínio desperdiçáveis. Preparando o bife, é só jogar fora a frigideira com a horrível gordura velha" ou então "muffins vêm em formas de assar que depois podem ser jogadas fora".

O que tem sido chamado de "cultura descartável" ou "a ética de jogar tudo fora" começou nos EUA em meados do século XIX, quando uma variedade de materiais baratos torna-se disponível para a indústria. As inovações no equipamento de produção de papel, por exemplo, fizeram do papel um substituto prático para o tecido. (SLADE, 2007, p. 13) $)^{18}$

A valorização do novo e do estilo, assim como uma naturalização da ideia de descartável, antes inexistente, passam a figurar o contexto em que a obsolescência programada se desenvolveu, colaborando para que isso acontecesse.

A partir do exemplo dos carros, também outros segmentos da indústria aderiram à obsolescência psicológica para aumentar suas vendas. Packard (1965) relata o exemplo de prática da obsolescência para aumentar a venda de descascadores de batatas. A indústria fabricante deste item verificou, por meio de pesquisas de mercado, que seus consumidores tinham o costume de descascar as batatas em cima de uma folha de jornal e descartar tudo ao final do processo. Para aumentar as vendas, a empresa desenhou um produto que tivesse a cor mais próxima possível de uma batata, fazendo com que ele se confundisse com as cascas e fosse jogado fora junto com elas, levando a compra de um novo item. Para solucionar o problema das vendas, afinal, a cor escolhida não tornava o produto atraente, foi desenhada uma em-

\footnotetext{
${ }^{17}$ Tampax, along with other disposables, not only habitueted women to increasing levels of repetitive consuption but broadened the cultural acceptance of the throwaway ethic, a necessary accompaniment to planned obsolescence.” (SLADE, 2007, p. 23)

18 "What has been called 'disposable culture' or 'the throwaway ethic' began in America around the middle of the nineteenth century when a variety of cheap materials become available to industry. Innovations in the machinery of paper production, for example, made paper a practical substitute for cloth.” (SLADE, 2007, p. 13)
} 
balagem de cartão vermelho, que destacava os descascadores de batata onde quer que estivessem expostos, mas que deveria ser descartado, tão logo o produto começasse a ser utilizado.

Papanek (1971) coloca o estilo ao lado da obsolescência programada, como gêmeos nascidos da união dos caprichos dos consumidores com a tecnologia. É importante ressaltar que, para que a prática da obsolescência programada se aplicasse de fato, outros fatores de fato passaram a ter mais peso no contexto das décadas de $1930 \mathrm{e}$ 1940. Nessa época, publicidade e design passam a ganhar espaço na sociedade. Outro fator importante foi o início da venda a crédito. Como descreve Lippincott, em seu livro de 1947, no qual procura educar os produtores para a obsolescência programada, enaltecendo todos os benefícios da produção e do consumo de massa,

\begin{abstract}
A indústria automobilística pode tomar a parte do crédito na construção da nova profissão de designer industrial (industrial design). Isso porque a indústria automotiva esteve entre as primeiras a aplicar a obsolescência do estilo como meio de promover seus produtos. Por meio de uma divulgação nacional, boa publicidade e periódicas mudanças de estilo, esta indústria, mais do que qualquer outra, condicionou o consumidor americano a esperar mudanças e melhorias contínuas nos produtos. Isso só foi possível graças à grande produção em massa. (LIPPINCOTT, 1947, p. 43) $)^{19}$
\end{abstract}

Porém, na opinião de um diretor da união dos consumidores, a obsolescência de desejabilidade compromete a qualidade do produto, pois

\footnotetext{
Quando se liga desenho a vendas e não a função do produto, como acontece cada vez mais, e quando se baseia a estratégia de venda em frequentes mudanças de estilo, há certos resultados quase inevitáveis: tendência ao emprego de materiais inferiores; redução do tempo necessário para o desenvolvimento de um produto sólido; e negligência quanto à qualidade e adequada inspeção. $\mathrm{O}$ efeito dessa obsolescência congênita é um disfarçado aumento de preço para o consumidor, sob a forma de vida mais curta do produto e, com frequência, de contas de consertos maiores. (PACKARD, 1965, p. 119)
}

A Inglaterra abraça a ideia de consumismo e de obsolescência programada com o mesmo entusiasmo que os EUA na segunda metade da década de 1970, abrindo seu mercado (THE MAN, 2014). Segundo o documentário The man who made us spend, isso se dá na Inglaterra graças às compras a crédito que passam a vigorar a partir de

\footnotetext{
19 "The automotive industry can take the lion's share of credit in building the new profession of industrial design. This is because the automotive industry was among the first to apply style obsolescence as a means of moving merchandise. Through wide national advertising, good publicity and continual yearly style changes, this industry more than any other has conditioned the American consumer to expect change and continued product improvement. All this has been possible only because of high mass production.” (LIPPINCOTT, 1947, p. 43)
} 
então, assim como a informatização que passou a fazer parte da produção dos artefatos (com a invenção do programa que depois se transformou no AutoCAD), possibilitando reduzir espessuras e materiais para baratear produtos, assim como facilitar seu desenho, possibilitando uma variedade antes impossível. Esses dois pontos são identificados por Packard (1965) como estratégias para manter um crescimento constante de compras e da economia e será explorado no item "Práticas de consumo", mais à frente.

Porém, vale destacar produtos que ilustram como a obsolescência psicológica passou a fazer parte do cotidiano das pessoas. São citados no documentário e também por Whiteley (1993) o sucesso dos relógios Swatch na década de 1980. A empresa suíça apresentava a cada ano cem novos modelos de relógio, transformando um produto que antes durava a vida toda em um produto que deveria ser combinado com a roupa do dia, aliado aos conceitos da moda, como aconteceu com o carro. Da mesma maneira, a marca de móveis Ikea também foi capaz de modificar a ideia de perenidade de móveis, antes comprados para durar um vida.

O estágio mais recente da história da obsolescência dos produtos começou quando a indústria identificou a possibilidade de manipular falhas materiais em produtos manufaturados. É normal um produto apresentar defeitos após um uso prolongado, devido ao desgaste de seus materiais. Mas durante a Depressão, como uma medida de economia, os fabricantes foram forçados a usar materiais inferiores na produção de seus bens, pois isso reduzia custos unitários. E esses mesmos fabricantes perceberam que o uso de materiais com qualidade inferior também estimulava a demanda, por forçar um consumo repetitivo (SLADE, 2007, p. 5).

O primeiro caso emblemático de obsolescência artificial de que se tem notícia foi o da lâmpada. Segundo o documentário Obsolescência programada: comprar, tirar, comprar (2010), este não é apenas o primeiro caso de obsolescência programada de que se tem notícia, mas é também o primeiro caso de cartel que se conhece - o Phoebus - , em que as poucas empresas produtoras de lâmpadas espalhadas pelo mundo, entre elas Osram (na Alemanha) e a Phillips (na Holanda), reuniram-se para trocar informações sobre patentes e determinar o tempo de vida útil das lâmpadas. Dentre os registros impressos apresentados no documentário, estão multas recebidas por empresas fabricantes de lâmpadas vendidas com tempos de vida maiores do que o estipulado, além de documentos que registram a definição desse tempo. Cronologicamente, Thomas Edison apresentou o primeiro modelo de lâmpada comercializado em 1871, como algo muito estável e com uma estimativa de duração bastante longa (existem documen- 
tos de modelos feitos para durar 100 mil horas).$^{20}$ Sua fabricação começou em 1895, e o cartel tem uma data estimada de início em 1924, ano no qual as lâmpadas eram comercializadas com 2,5 mil horas de vida, tempo esse que foi reduzido a mil horas até 1940, de acordo com o documentário The man who made us spend (2014).

Parte desses documentos é exposto também por Slade (2007):

O memorando [...] recomendava o encurtamento deliberado da vida útil do produto, "se isso fosse feito, estimamos que resultaria no aumento de $60 \%$ no comércio de lâmpadas. Não encontramos nenhuma razão lógica, tanto do nosso ponto de vista como no do fabricante de baterias, para que tal mudança não seja feita neste momento". Este memorando, datado de 1932, descreveu a prática da obsolescência planejada sem nomeá-la, embora a política que encorajasse não estivesse ainda implementada neste momento. Ainda assim, todos os elementos do que se tornaria conhecido como obsolescência planejada ou morte do produto estavam claramente descritos em 1932. Eles incluem a conexão entre adulteração e consumo repetitivo, o termo “obsolescência planejada" em si e a pesquisa científica aplicada à vida útil de um produto. Só o que faltava era que eles se combinassem. Quando exatamente isso aconteceu não está claro, mas a partir de 1950 a combinação já ocorria há muito tempo. (SLADE, 2007, p. 81) 21 $^{21}$

Segundo Slade (2007), na época em que esses conceitos foram definidos, a preocupação dos produtores era vender mais, e a tendência era encorajar os consumidores a substituírem peças - ou mesmo o produto todo - em lugar de consertá-las. Manutenção não era uma questão central, e, muitas vezes, a peça que apresentava o defeito ficava numa parte inacessível do produto, induzindo a troca do completa do produto. Packard (1965, p. 97) aponta como as principais causas dos defeitos uma sobrecarga do aparelho, o emprego de peças plásticas mais suscetíveis a quebras ou deformações, "e houve denúncias de que os fabricantes de aparelhos domésticos estavam diminuindo a proporção do aço, o tamanho e o número de parafusos e a qualidade do acabamento interior onde é importante a proteção contra a corrosão".

Um bom exemplo mais recente da estratégia apontada por Packard é o do iPod, player de MP3 da marca Apple, exibido no documentário The man who made us spend. Lan-

\footnotetext{
${ }^{20}$ No documentário, é contada também a história da lâmpada mais antiga de que se tem notícia. Consta que está acesa no corpo de bombeiros da cidade americana de Livermore (California) desde 1901, é filmada 24 horas por dia, desde sua descoberta em 1971, e que, de lá para cá, duas câmeras já quebraram enquanto a lâmpada segue acesa.

${ }^{21}$ The memo [...] recommended a deliberated shortening of the product life span, "if this were done, we estimate that it would result in increasing our flashlight business approximately 60 percent. We can see no logical reason either from our standpoint or that of the battery manufacturer why such a change should not be made at this time". This memo, dated 1932, described the practice of planned obsolescence without naming it, though the policy it encouraged was not implemented at time. Still, all the elements of what would become known as planned obsolescence or death dating were clearly in place by 1932 . These include the connection between adulteration and repetitive consumption, the term "planned obsolescence" itself, and scientific research into a product life span. All that was needed was for them to come together. When exactly this happened is unclear, but by the 1950 s this combination had long since taken place.” (SLADE, 2007, p. 81)
} 
çado em 2004, o iPod foi construído de maneira que, ao fim da vida útil de sua bateria, o custo elevado para sua troca incentivasse a compra de um novo. $\mathrm{O}$ apresentador do documentário entrevista um consumidor, que ao identificar o problema com a bateria, ligou e gravou sua conversa com a assistência técnica da Apple. Na conversa, o atendente pergunta quanto tempo tem o iPod cuja bateria não carrega mais, ao que o interlocutor responde "dezoito meses". O atendente responde, então, que esse é mesmo o tempo que dura a bateria e que para trocá-la seria necessário encaminhar o equipamento por correio e arcar com o custo do envio, além do custo de conserto que correspondia a aproximadamente $60 \%$ do valor para sua compra. 0 próprio atendente diz que seria mais vantajoso adquirir o novo modelo.

Os três tipos de obsolescência se misturam no decorrer do tempo, tornando descartáveis equipamentos antes classificados como duráveis, e "o casamento entre transistores e circuitos impressos nos anos 1950 tornou obsoleta toda a geração de eletrônicos de consumo do pós-guerra, pois tornou-os irreparáveis" (SLADE, 2007, p. 105). ${ }^{22} \mathrm{O}$ rádio, lançado inicialmente como um móvel da casa, transformou-se em equipamento de bolso graças às novas tecnologias de miniaturização que reduziram suas placas de circuito de maneira que, de tão pequenas, não pudessem ser reparadas manualmente, acabando por transformá-lo também em um produto descartável.

Esta nova fase de obsolescência começou com o aparecimento de circuitos miniaturizados cada vez mais poderosos em cada canto da vida prática, do fliperama ao quarto de brincar das crianças. Junto com os rádios de transistores e calculadoras portáteis, esses brinquedos e videogames marcam o início do e-waste como sabemos hoje. (SLADE, 2007, p. 188) ${ }^{23}$

E-waste, ou resíduo eletrônico, é o termo usado para descrever aparelhos eletrônicos antigos, em fim de vida ou descartados. Podem ser eletrodomésticos de grande porte, como máquina de lavar roupa, geladeira e ar-condicionado; eletrodomésticos de pequeno porte, como aspirador de pó, liquidificador e ferro de passar roupa; equipamentos de escritório, informações e comunicação, como computadores e celulares; equipamentos de entretenimento e eletrônicos, como televisão, rádio e CD player; equipamentos de iluminação, como tubos fluorescentes; ferramentas elétricas e eletrônicas, como máquina de costura e cortador de grama; brinquedos, equipamentos de lazer, de esportes e recreativos, como conjuntos de trem elétrico e máquina caça

\footnotetext{
22 "The 1950 s marriage of transistors and printed circuits rendered the postwar generation of consumer electronics obsolete, because it made them, for all intents and purposes, unrepairable." (SLADE, 2007, p. 105)

${ }_{23}$ "This new phase of obsolescence began with the appearance of increasingly powerful miniaturized circuitry in every corner of daily life, from the pinball parlor to the children's playroom. Together with transistor radios and hand-held calculators, these toys and videogames mark the beginning of e-waste as we know it today.” (SLADE, 2007, p. 188)
} 
-níqueis (E-WASTE DEFINITION, 2017). Na definição da Step (Solving the waste problem), órgão ligado à ONU, e-waste refere-se a todos os tipos de equipamentos elétricos e eletrônicos (ou parte deles) descartados como resíduos, ou seja, descartados sem a intenção de reutilização. (WHAT IS E-WASTE, 2017) Segundo Slade (2007), o primeiro caso de $e$-waste foram as calculadoras, por volta de 1965.

É importante ressaltar que os exemplos identificados com o início da obsolescência programada são de antes do termo sustentabilidade ${ }^{24}$ sequer existir, ainda que a preocupação com a geração de lixo e o consumo repetitivo já façam parte do discurso de Packard e Papanek desde a década de 1960.

Conforme dito anteriormente, os produtores dessa época viam e estimulavam a prática como uma salvação possível para a economia americana. Não viram isso como uma perspectiva de sustentabilidade com recursos finitos, mas de uma perspectiva de abundância, conforme descreve Lippincott:

\footnotetext{
Nosso costume de trocar nossos automóveis todo ano, de ter um novo refrigerador, aspirador de pó ou ferro elétrico a cada três ou quatro anos é econômico. Nossa vontade de nos desfazer de algo antes de estar completamente desgastado é um fenômeno que não se nota historicamente em nenhuma outra sociedade. É um hábito verdadeiramente americano, e é profundamente baseado em nossa economia de abundância. (LIPPINCOTT, 1947, p. 14) ${ }^{25}$
}

Seguindo a cronologia proposta por Slade (2007), a sequência de produtos identificados com a obsolescência é: calculadora, rádio, videogame, computador e telefone celular, atual campeão no $e$-waste: em 2002, mais de 130 milhões de telefones portáteis que ainda funcionavam foram descartados nos Estados Unidos (SLADE, 2007).

Neste ponto da cronologia, é possível retornar novamente aos dados do lixo eletrônico contemporâneo apresentados na introdução, assim como aos dados levantados no questionário aplicados nesta pesquisa, que dizem respeito às práticas de consumo atuais e com resultados expostos no capítulo 4.

Vale destacar a sofisticação da obsolescência artificial, que desde a década de 1970, com o advento dos microchips, citados anteriormente, criaram ferramentas mais

\footnotetext{
${ }^{24}$ Definido apenas em 1987, pelo World Commission on Environmental and Development, o conceito de sustentabilidade foi descrito como "desenvolvimento que atende às necessidades do presente sem comprometer a capacidade das futuras gerações atenderem às suas necessidades" (PLATCHECK, 2012).

${ }^{25}$ "Our custom of trading in our automobiles every year, of having a new refrigerator, vacuum cleaner or electric iron every three or four years is economically sound. Our willingness to part with something before it is completely worn out is a phenomenon noticeable in no other society in history. It is truly an American habit, and it is soundly based on our economy of abundance." (LIPPINCOTT, 1947, p. 14)
} 


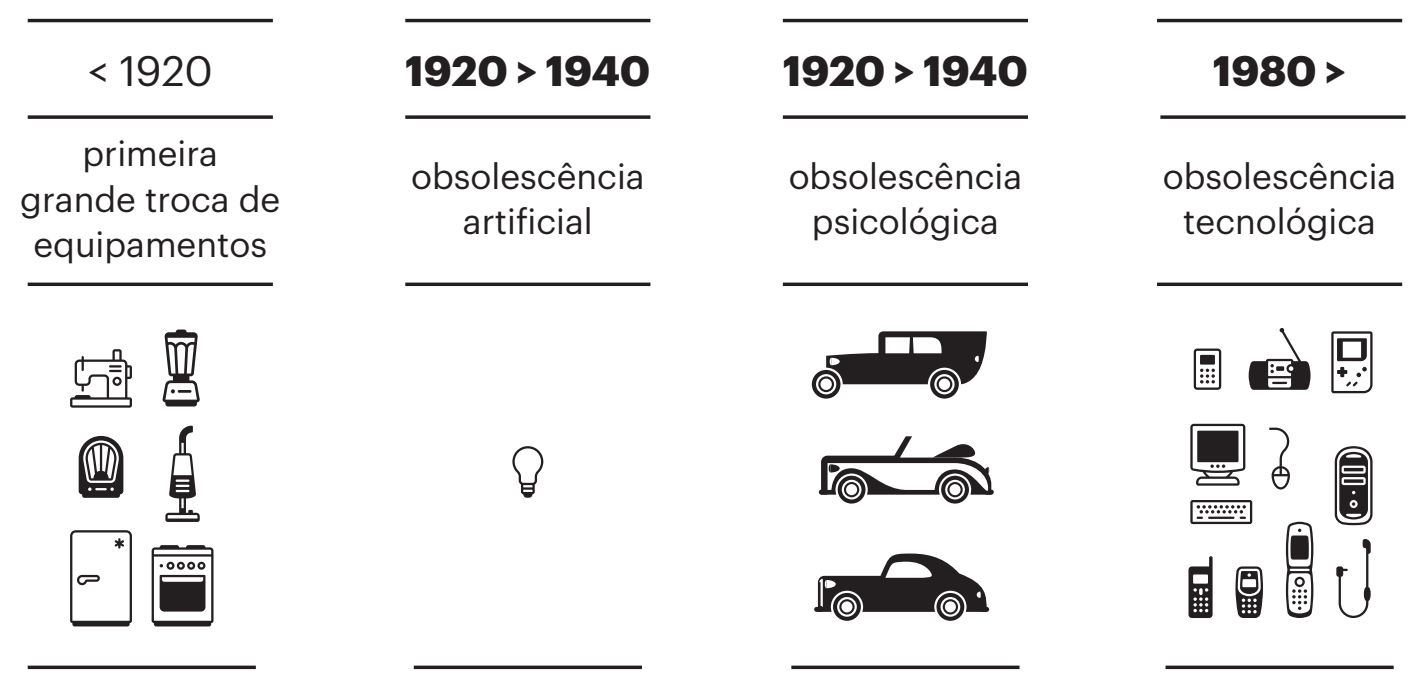

Figura 8: Linha do tempo de acordo com a cronologia porposta por Slade (2007). (Fonte: a autora)

sofisticadas para datar a morte de um produto. Segundo Slade (2007), nesta época os EUA desconfiavam que a Rússia estava importando tecnologia americana para copiá-la. O lançamento do primeiro satélite russo ao espaço, sem grandes divulgações dos centros de pesquisa em que foram feitos, fez com que essa desconfiança se agravasse e se comprovasse em pouco tempo. Foi descoberto que, por meio dos produtos americanos exportados para a Rússia, a tecnologia americana era copiada. Frente a essa constatação, o governo americano evoluiu um pouco mais a prática da obsolescência artificial, usando a recém-desenvolvida tecnologia dos microchips, conforme diálogo de William Casey, então diretor da CIA, com Gus W. Weiss, então assistente especial da Secretaria de Defesa dos EUA : "Nós não temos que contar somente com a obsolescência planejada. Podemos dar um passo adiante. Podemos atrapalhá-los completamente fazendo com que alguns dos itens roubados funcionem mal de maneiras espetaculares" (citado em SLADE, 2007, p. 254) ${ }^{26}$ O documentário Obsolescência programada (2010), mencionado anteriormente, começa com uma cena contemporânea que ilustra precisamente esta nova modalidade de obsolescência artificial: um rapaz tentando imprimir um documento em sua impressora caseira, sem sucesso. $\mathrm{Na}$ sua tela, surge um aviso de que uma das tintas acabou e que não é possível imprimir. No decorrer da entrevista, ele nos conta que, incomodado com esse problema, localizou um outro rapaz em outra parte do mundo que desenvolveu um programa capaz de solucionar seu problema. Isso porque a impressora tem em sua construção um chip

26 "We don't have to leave it at planned obsolescence. We could take it a step further. We could shake their morale completely by making some of the stolen items malfunction in spectacular ways.” (SLADE, 2007, p. 254) 
que, independente da quantidade de tinta utilizada, bloqueia as impressões quando é alcançado um determinado número de páginas impressas.

A obsolescência psicológica, assim como a obsolescência artificial, estimulava - e segue estimulando - um consumo repetido de artefatos. Isso começa a ganhar corpo com a indústria automobilística, que, conforme visto anteriormente, assistiu um aumento expressivo de suas vendas desde a adoção do modelo anual. Harley Earl, designer de automóveis que trabalhou por muitos anos na GM, falou abertamente sobre o que chamava de obsolescência dinâmica: "Nosso grande trabalho é acelerar a obsolescência. Em 1934 a troca de carros ocorria em média a cada cinco anos: agora (1955) a cada dois anos. Quando for um ano, teremos uma pontuação perfeita” (SLADE, 2007, p. 45). ${ }^{27}$

É interessante notar que todo o percurso da obsolescência programada foi discutido publicamente por meio de jornais e revistas da época, principalmente nos EUA entre as décadas de 1950 e 1960. As discussões influenciavam consumidores e fabricantes, modificando suas estratégias com o passar dos anos.

São exemplos disso os anúncios de carros, enaltecendo ou não a estratégia, como nos anúncios das figuras 9 e 10. O primeiro reproduz um dos anúncios de uma série da Ford de 1926 (parte da série está reproduzida na Figura 4) que valoriza as pequenas diferenças entre os carros e a diversificação de modelos, destacando a mulher como público alvo, como foi descrito anteriormente. $\mathrm{O}$ anúncio leva os dizeres: "Pesquisas revelam porque as mulheres estão tão entusiasmadas pelo modelo atual da Ford. Ele é bonito.”. O segundo mostra a campanha da Volkswagen, da década de 1960, que vai contra os acessórios sem função ou as mudanças de estilo, com os dizeres "A teoria da evolução da Volkswagen". O anúncio exibe modelos de carros quase que idênticos, ou seja, vai contra o modelo anual de carro, que pouco tempo antes era enaltecido.

A bibliografia principal desta pesquisa ilustra um pouco a cronologia descrita até aqui: o livro de Lippincott (1947) é contemporâneo dos modelos anuais de carro, com adereços estéticos sem grande funcionalidade citados anteriormente, e prega a obsolescência psicológica quase como uma obrigação dos fabricantes. $\mathrm{O}$ autor explora a ideia de que quem não adota a obsolescência está fora do mercado. Um exemplo disso é o título do capítulo 2 do livro, que leva o nome de "Obsolescência: a chave do progresso" ${ }^{28}$ Em seguida, o livro de Packard (1965) trata das questões do capitalismo e do

\footnotetext{
27 "Our big job is to hasten obsolescence. In 1934 the average car ownership spam was 5 years: now (1955) it is 2 years. When it is 1 year, we will have a perfect score.”(SLADE, 2007, p. 45)

28 "Obsolescence - the keynote of a new prosperity".
} 

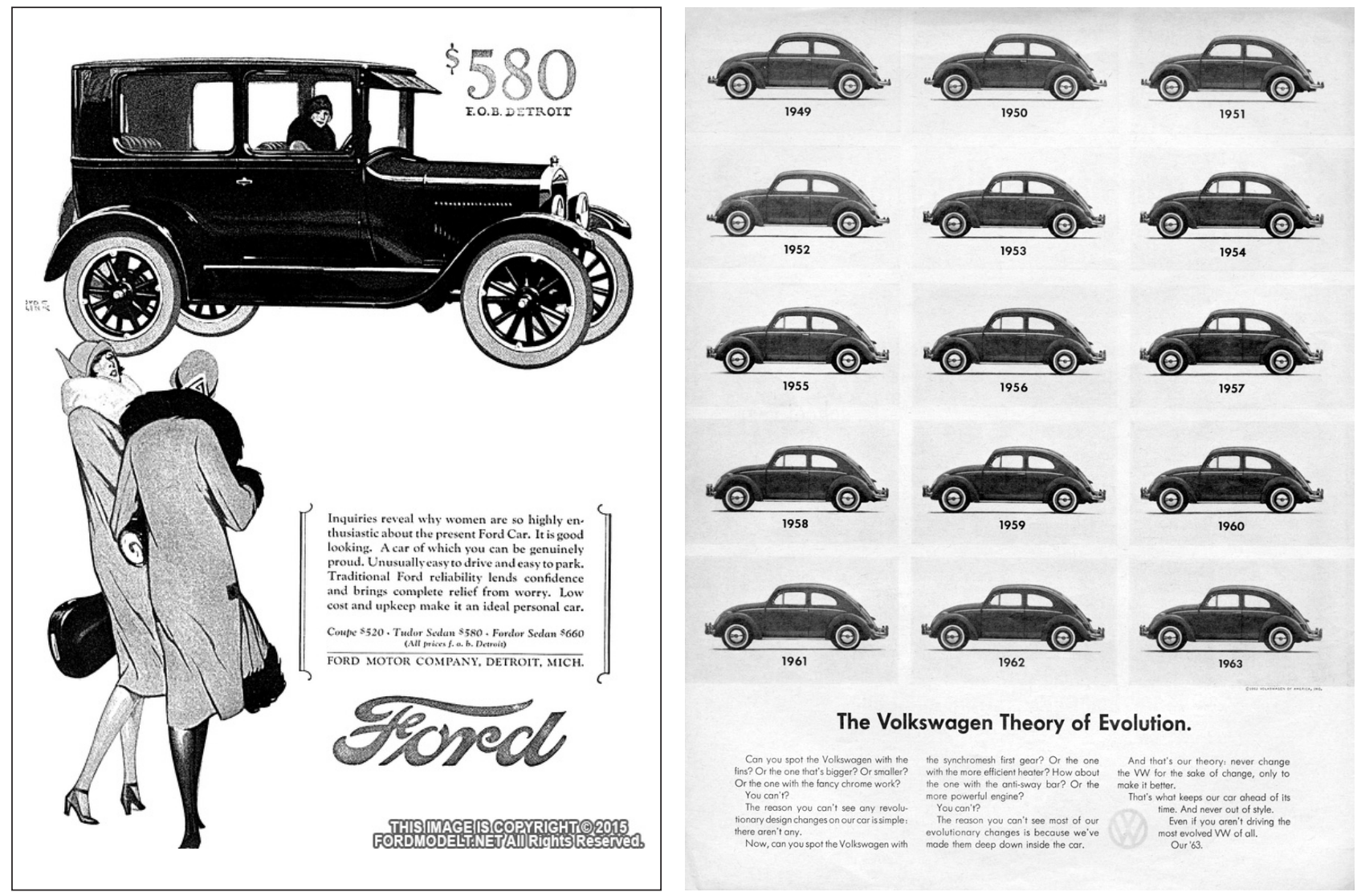

9

10

Figura 9. Anúncio da Ford de 1926.

Texto do anúncio: "Inquires reveal why women are so highly enthusiastic about the present Ford Car. It is good looking. A car of which you can be genuinely proud. Unusually easy to drive and easy to park. Traditional Ford reliability lends confidence and brings complete relief from worry. Low cost and upkeep make it an ideal personal car.” (Fonte: http://www.fordmodelt.net/gallery2/index.php?/category/11)

Figura 10. Anúncio da Volkswagen de 1963.

Texto do anúncio: “The Volkswagen Theory of Evolution./Can you spot the Volkswagen with the fins?/ Or the one that's bigger?/Or smaller?/Or the one with the fancy chrome work?/You can't?/The reason you can't see any revolutionary design changes on our car is simple: there aren't any./Now, can you spot the Volkswagen with the synchromesh first gear? Or the one with the more efficient heater? How about the one with the anti-sway bar? Or the more powerful engine?/You can't?/The reason you can't see most of our evolutionary changes is because we've made them deep down inside the car./And that's our theory: never change the VW for the sake of change, only to make it better./That's what keeps our car ahead of its time. And never out of style./Even if you aren't driving the most evolved VW of all./Our “63.” (Fonte: http://www.plosin.com/beatbegins/projects/haine/volks2.htm) 
que ele chama de "crescimentismo" - conceitos que serão mais explorados no item "Consumismo" deste capítulo - incluindo a obsolescência como uma das estratégias para o desperdício. O livro vai diametralmente contra os ensinamentos de Lippincott. Já Papanek (1971) incorpora as críticas de Packard, trazendo suas reflexões para o campo do design e propondo soluções para os problemas gerados pela obsolescência programada. Slade (2007) traz dados mais atuais da obsolescência, enfatizando por meio dos dados de lixo eletrônico sua impossibilidade de manutenção.

É importante também ressaltar que a obsolescência programada é uma invenção americana, e por esta razão foi adotada uma bibliografia quase que exclusivamente americana. Porém, com a globalização, países europeus e muitos outros adotaram o American way of life no que diz respeito ao consumismo e a obsolescência programada, de acordo com Whiteley (1993) e também com o documentário The man who made us spend (2013). “O que testemunhamos desde a chegada da riqueza e dos mercados saturados é o triunfo do American way, tanto ideológica quanto praticamente" (WHITELEY, 1993, p. 45). ${ }^{29}$

Por outro lado, segundo De Masi (RODA VIVA, 2013) e Magalhães (2014), o Brasil copiou por 450 anos o modelo europeu e depois por cinquenta anos o modelo americano, de acordo com qual vivemos atualmente. De acordo com Magalhães (2014, p. 106), "ao longo do processo histórico, o nosso grande pecado decorre realmente de uma posição imobilista", ou seja, o Brasil não propôs novos modelos, mas adotou inicialmente o da nossa colônia, para num segundo momento adotar o americano.

Dessa maneira, conforme as afirmações de De Masi e Magalhães (2014), é possível afirmar que o modelo americano descrito foi e segue sendo adotado no Brasil, ainda que não haja bibliografia nacional que descreva as práticas de consumo relacionadas com a obsolescência programada.

\subsection{Definições de obsolescência programada}

Para Packard (1965), a obsolescência programada decorre da necessidade de criar novas necessidades e estimular novos desejos, para assim, conforme visto anteriormente, isso dar vazão aos grandes estoques acumulados e movimentar a economia americana em crise. $\mathrm{O}$ autor define três tipos de obsolescência programada:

29 "What we have been witnessing since the arrival of affluence and saturated markets is the triumph of the American Way, both ideologically and practically.” (WHITELEY, 1993, p. 45) 
a) Obsolescência de função. Dá-se quando um novo produto que executa melhor determinada função é introduzido no mercado, tornando sua versão anterior antiquada.

b) Obsolescência de desejabilidade. Dá-se quando um produto "torna-se 'gasto' em nossa mente porque um aprimoramento de estilo ou outra modificação faz com que fique menos desejável" (PACKARD, 1965, p. 51). Neste caso, muitas vezes produtos que ainda estão satisfatórios em termos de qualidade ou performance acabam sendo descartados antes do fim de seu ciclo de vida.

c) Obsolescência de qualidade. Dá-se quando o produto se desgasta naturalmente ou em tempo determinado, geralmente não muito longo. Ela conta ainda com alguns fatores: emprego de materiais menos duráveis; inclusão de adereços (por estilo e não por função) nos produtos, aumentando o número de peças passíveis de serem quebradas; alto custo ou dificuldade de encontrar peças sobressalentes.

Para Packard (1965, p. 51) o primeiro tipo é "louvável”, pois “todos aplaudimos quando podemos discar um número a centenas de milhas de distância ao invés de fazer a ligação por intermédio de telefonistas”. Porém quando, de acordo com o autor, há duplicação do equipamento, como no caso da substituição dos discos de alta fidelidade pelos estereofônicos, isso pode apontar para reflexos de manipulação.

Em outras palavras, alguns tipos de obsolescência programada trazem progresso e são muito bem-vindos, enquanto outros trazem muito pouco benefício.

Papanek classifica estilo e obsolescência como gêmeos sombrios, nascidos da mestiçagem entre a tecnologia e os caprichos dos consumidores artificialmente acelerados (PAPANEK, 1971, p. 34), e lista quatro tipos de obsolescência, com diferenças nos nomes, mas características muito parecidas com as de Packard (1965), descritas anteriormente:

a) Obsolescência tecnológica. Tal qual a descrita por Packard, se dá quando se descobre uma maneira melhor de fazer as coisas.

b) Obsolescência estilística. Correspondente à obsolescência de desejabilidade descrita por Packard, mas que traz no nome o entendimento de que produtos serão descartados por estarem "fora de moda".

c) Obsolescência material. Correspondente à obsolescência de qualidade descrita por Packard, porém restringido seu desgaste à ação natural do tempo.

d) Obsolescência artificial. Também correspondente à obsolescência de qualidade descrita por Packard, porém especificando o desgaste a um intervalo de tempo previ- 
sível, que se dá sobretudo por duas razões: pela escolha de materiais ou acabamentos menos duráveis ou porque partes significativas do produto não são substituíveis ou reparáveis. Para o autor, esta é a "sentença de morte” de um produto.

Giles Slade define a obsolescência programada como o nome usado para descrever as diversas de técnicas utilizadas para limitar artificialmente a durabilidade de um bem e estimular o consumo repetitivo (SLADE, 2007, p. 5), definindo três tipos, assim como Packard (1965):

\section{a) Obsolescência tecnológica (obsolescence due to technological innovations).}

Iniciada no final do século XIX e início do século XX com a grande troca de equipamentos domésticos impulsionada pela chegada da luz elétrica. Caracteriza-se, da mesma maneira que para os autores anteriores, por uma nova tecnologia, que torna seu antecessor obsoleto.

b) Obsolescência psicológica, progressiva ou dinâmica. Iniciada com o modelo anual dos carros, por volta de 1913. Refere-se, segundo o autor, ao mecanismo de mudanças no estilo dos produtos como uma estratégia de manipulação dos consumidores para um consumo repetitivo. $O$ termo obsolescência progressiva, especificamente, foi introduzido por Justus George em artigo pulicado na revista da qual era o editor - Advertising and Selling - no ano de $1928 \mathrm{e}$ refere-se às compras cuja motivação é estar atualizado ou ter uma "sensação de modernidade". Slade destaca o fator psicológico de morte de um produto como a "estratégia que coloca o consumidor em um estado de ansiedade levando-o a crer que um produto velho é indesejável, inútil e vergonhoso, se comparado com algo que é novo"; e o estilo como "um tipo especializado de obsolescência psicológica", que procura chamar a atenção do consumidor para características visuais (ou de design) dos produtos consumidos, "que vão desde carros, telefones celulares, roupas, chapéus, joias, laptops, isqueiros e bagagens a PDAs, facas de bolso, bolsas, sapatos, óculos de sol e relógios” (SLADE, 2007, p. 50).

c) Obsolescência planejada. Inicia-se por volta de 1940 e seria equivalente à obsolescência de qualidade ou artificial mencionadas anteriormente. Segundo Slade, ela passa a vigorar no momento em que os produtores se dão conta de que podem manipular a falha física de seus produtos.

Para a pesquisadora Valquíria Padilha, "obsolescência é o estado de algo que se tornou ultrapassado ou perdeu a utilidade; [...] deriva de obsoleto, que quer dizer antigo ou caduco". Ela também destaca que algo pode ser tornar obsoleto devido ao seu desgaste natural, porém se pudermos definir quando um produto vai falhar ou tornar-se velho, 
programando seu fim antes mesmo da ação da natureza e do tempo de uso [...] temos uma obsolescência programada que se refere ao ato de estabelecer uma data de morte a um produto, seja através de mau funcionamento ou por se tornar velho perante as tecnologias mais recentes existentes no momento. (PADILHA, 2016)

“Criação organizada da insatisfação" é a definição utilizada no documentário da BBC The man who made us spend (2014).

Para esta pesquisa, adotaremos a nomenclatura exposta no quadro a seguir.

Quadro 1

Tipos de obsolescência: nomenclatura adotada na pesquisa

\begin{tabular}{llll}
\hline nomes adotados & & principais características \\
\hline na pesquisa & pelos autores & \\
\hline $\begin{array}{lll}\text { obsolescência } \\
\text { tecnológica }\end{array}$ & $>$ função (Packard) & um avanço tecnológico \\
\hline $\begin{array}{lll}\text { obsolescência } \\
\text { psicológica }\end{array}$ & $>$ de desejabilidade (Packard) & uma mudança de estilo \\
\hline obsolescência & $>$ de qualidade (Packard) & $\begin{array}{l}\text { desgaste material do produto inteiro } \\
\text { ou de algum componente, podendo }\end{array}$ \\
ortificial & $>$ artificial/material (Papanek) & $\begin{array}{l}\text { ocorrer natural ou intencionalmente } \\
\end{array}$
\end{tabular}

Fonte: a autora.

\subsection{Práticas de consumo}

No fim da década de 1940 e início da década de 1950, era preciso que a economia americana funcionasse em níveis cada vez mais altos, fazendo surgir "um clamor em prol de "crescimento", definido por Packard (1965) como "crescimentismo".

A depressão de fins da década de 1950 serviu para muitos como aguda advertência do dilema que se desenvolvia devido à necessidade de produção cada vez maior. [...] Em toda a nação, industriais e líderes governamentais de todas as correntes advertiram os cidadãos de que precisavam continuar comprando para seu próprio bem. (PACKARD, 1965, p. 15)

A obsolescência programada de desejabilidade e de qualidade passa a ser adotada abertamente neste período, como escancara o título de matéria de Home Furnishings Daily de 1958: "Obsolescência será a chave para a campanha da Westinghouse” (PACKARD, 
1965, p. 112). Ela passa a ser aclamada por muitos como solução para a economia americana, chegando a ser debatida no congresso por volta de 1960, no sentido de a legislação colaborar para haver "concessões mais liberais para a obsolescência do equipamento comercial a fim de fomentar o crescimento econômico, permitindo a isenção mais rápida de impostos sobre o equipamento existente" (PACKARD, 1965, p. 21).

Conforme mencionado anteriormente, Alfred Sloan e Henry Ford teriam sido os primeiros empresários a estimular essa nova produção de massa, percebendo que "volume é a chave da produção". "O esforço da indústria automotiva para um volume cada vez maior trouxe novos conceitos de publicidade, merchandising e distribuição em massa que, por sua vez, foram copiados pela maioria das outras indústrias americanas" (LIPPINCOTT, 1947, p. 10).

\footnotetext{
A obsolescência em todas as suas formas — tecnológica, psicológica ou planejada — é uma invenção exclusivamente americana. Inventamos não só produtos descartáveis, como fraldas, câmeras e lentes de contato, mas o conceito de descartável em si, como um precursor necessário para nossa rejeição da tradição e promoção do progresso e da mudança. Conforme os fabricantes americanos foram aprendendo a explorar a obsolescência, o consumidor americano foi aceitando-a em cada vez mais partes de suas vidas. (SLADE, 2007, p. 4-5) ${ }^{30}$
}

A obsolescência programada passa a ser, então, uma prática a ser incentivada na vida de consumidores e fabricantes, fazendo do consumo e descarte mais frequentes uma nova maneira de se relacionar com os objetos. "Móveis, refrigeradores, tapetes — tudo quanto outrora era comprado para durar anos ou uma vida - são agora substituídos com a regularidade do tinir das caixas registradoras" (PACKARD, 1965, p. 39). Para manter o "crescimentismo", o autor atrela o conceito de saturação e abundância ao de desperdício e identifica as estratégias necessárias "que transformassem grande número de americanos em consumidores vorazes, esbanjadores, compulsivos - e estratégias que fornecessem produtos capazes de assegurar tal desperdício" (PACKARD, 1965, p. 24).

Para que a obsolescência artificial e de desejabilidade tivessem sucesso, porém, era preciso uma mudança nos paradigmas: velho em contraposição com novo, durável em contraposição com descartável. Era preciso mudar também a noção tradicional de que a durabilidade é o principal aspecto de mérito dos produtos, garantindo muitas vezes o valor pago por eles. Passa-se então a atrelar também a noção de velho a ruim, e novo a bom.

30 "Deliberate obsolescence in all its forms - technological, psychological, or planned — is a uniquely American invention. Not only did we invent disposable products, ranging from diapers to cameras to contact lenses, but we invented the very concept of disposability itself, as a necessary precursor to our rejection of tradition and our promotion of progress and change. As American manufacturers learned how to exploit obsolescence, American consumer increasingly accepted it in every aspect of their lives.” (SLADE, 2007, p. 4-5) 
Para manter as máquinas industriais funcionando, cada cidadão é “obrigado" a consumir tanto por ano. Para esse fim, o novo como característica é incentivado. [...] "Não queremos que as pessoas sejam atraídas por coisas velhas. Queremos que gostem das novas". (PACKARD, 1965, p. 38)

Passa-se a valorizar a aquisição dos objetos como se com eles pudéssemos nos transportar para o futuro, "quando todos os males do presente estarão eliminados, é avassaladora; além disso, é emocionalmente muito mais fácil viver no passado ou no futuro do que no presente" (FORTY, 2007, p. 274).

Segundo Whiteley (1993), é nessa época que o design passa a ter uma importância maior no desenho dos produtos, ainda como um estilista, pois ele poderia dar ao produto o que agora chamamos de "valor agregado', mas que antes era chamado de 'atrativo visual"'(WHITELEY, 1993, p.13). No mesmo sentido, Forty afirma que o design pode alterar "a maneira como as pessoas veem as mercadorias" (FORTY, 2007, p. 20). Nessa época o design era determinado pelo fabricante, e o designer tinha a função de tornar atraentes os produtos que os fabricantes queriam produzir, e não necessariamente o que os consumidores almejavam. Assim, segundo Whiteley,

os consumidores estavam sendo projetados para se adequar ao produto, e não o contrário. Mas o que é significativo para o design neste período entre guerras nos Estados Unidos é que se desenvolve a ideologia da economia de mercado, e essa ideologia constitui a base própria da qual o nosso design contemporâneo emerge. (WHITELEY, 1993, p. 13-14)

Esta mudança na importância do design diz respeito à maneira de produzir e comercializar os produtos. Se antes a preocupação estava na função dos artefatos, agora ela estava bastante voltada à sua aparência e ao consumo de massas. No que diz respeito à sua aparência, começa-se a atrelar status à posse dos artefatos, "como disse Eric Larrabee, em Detroit: 'As equações estão armadas: pequeno significa barato, que significa ruim, e grande significa caro, que significa bom"” (PACKARD, 1965, p. 32). No que diz respeito ao consumo de massas, quanto maior a produção e o consumo, menor o custo de produção unitário, e nesse sentido a qualidade dos materiais poderia ser diminuída para baixar custos uma vez que durabilidade deixou de ser uma qualidade fundamental para aquisição de produtos e a ideia de descartável já era mais aceita de uma maneira geral. No mesmo sentido, Slade (2007) afirma que o mundo estava em transição entre as décadas de 1920 e 1930, "pois as coisas novas substituíam constantemente as antigas, e velhos valores começavam a entrar em conflito com novos", essas mudanças talvez ajudem a explicar porque o conceito de obsolescência foi tão poderoso nesta época (SLADE, 2007, p. 62). 
Brooks Stevens, destacado desenhista industrial explicou nesses termos o planejamento da obsolescência: “Toda nossa economia é baseada em obsolescência planejada e todos quantos podem ler sem mover os lábios agora sabem disso. Fazemos bons produtos, convencemos as pessoas a comprá-los e no ano seguinte introduzimos deliberadamente algo que torne aqueles produtos velhos, antiquados, obsoletos... Não é desperdício organizado. É uma sólida contribuição à economia americana”. Devo acrescentar que outros desenhistas discordam do ponto de vista de Stevens. (PACKARD, 1965, p. 50)

Se por um lado a obsolescência programada ajudou a salvar a economia americana, por outro, para ser estabelecida valeu-se de mudanças conceituais importantes como foi visto e também de estratégias que mudaram a maneira como as pessoas relacionam-se com os objetos e a maneira como a sociedade se estabelece até hoje, conforme será discutido a seguir.

As práticas de consumo listadas abaixo foram explicitadas por Packard (1965) e fundamentais para estabelecer e, ao mesmo tempo, estimular a obsolescência programada, seguindo válidas e visíveis até hoje.

- Excesso. Era preciso vender mais. As pessoas são convencidas, então, a comprarem pacotes com mais de uma unidade do produto que necessitam e também de comprarem mais unidades do mesmo produto, pequenos ou grandes. Packard (1965) descreve as estratégias de convencimento das pessoas de que precisariam ter duas casas, uma de campo e outra na cidade, uma de trabalho e outra de recreação, o que as levaria, consequentemente, a ter duas cozinhas equipadas, dois quartos, duas salas, dois carros etc. A Figura 11 ilustra uma promoção nos dias de hoje.

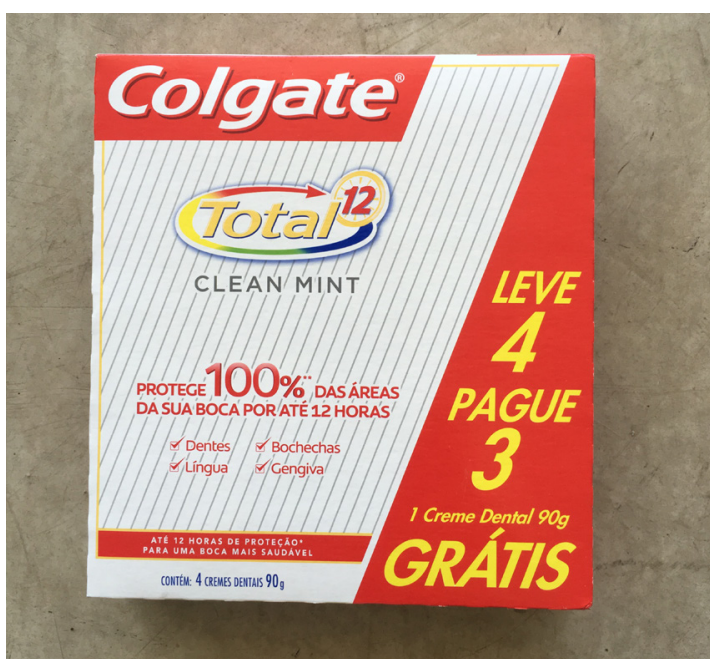

Figura 11. Promoção de pasta de dente. (Fonte: a autora) 
- Descartável. Valendo-se da preguiça identificada nos compradores americanos, comidas prontas em embalagens descartáveis passam a ser adotadas como nunca antes. Também "os brinquedos de plástico quebrável, com os quais aprendemos desde a tenra idade que tudo neste mundo é substituível” (Packard, 1965, p. 40). Segundo Papanek (1971), a ideia de descartável não é exatamente ruim, em alguns casos, como no dos utensílios hospitalares, em que é muito bem-vinda, pois economiza em processos de esterilização dispendiosos.

\footnotetext{
Mas quando uma nova categoria de objetos é projetada conscientemente para o descarte, dois novos parâmetros devem entrar no processo de design. Por um lado, o preço do objeto reflete seu caráter efêmero? [...] A segunda consideração diz respeito ao que acontece com o artigo descartável depois de ter sido descartado. As sucatas de automóveis seguem nossas rodovias de costa a costa. Pelo menos essas manchas horrorosas na paisagem têm um processo de oxidação (dolorosamente lento) a seu favor, de modo que em cinco ou vinte anos, os carros terão se transformado em pó. (PAPANEK, 1971, p. 94-95) (11 $^{31}$
}

- Crescimento democrático, entendido como "mais gente, mais consumidores". Packard (1965) descreve o relógio que funcionava no saguão do edifício do Departamento do Comércio dos Estados Unidos, em Washington, no final da década de 1950. Nele havia uma luz azul para nascimentos e outra vermelha para mortes. Uma luz branca mostrava o resultado líquido dos dois números. Ao lado do relógio, um cartaz enorme com os dizeres: "mais gente significa mais mercado".

- Dificuldade de manutenção e conserto dos equipamentos. Para tornar os produtos mais atrativos, alguns adereços eram incluídos nos produtos por estilo, e não por função. Assim, havia mais coisas para apresentar defeitos, e as peças sobressalentes estavam custando mais caro. Como a preocupação era vender mais, os produtos deveriam durar pouco para serem logo substituídos, assim sua manutenção não era uma questão central. Com isso, muitas vezes a peça que apresentava o defeito ficava numa parte inacessível do produto, tal como exemplificado pelo autor: "um ferro a vapor que só podia ser consertado arrebentando-o e arrancando os parafusos" (PACKARD, 1965, p. 124). As peças necessárias muitas vezes eram difíceis de se obter e os fornecedores muitas vezes deixavam de fornecer informações que facilitassem os consertos - a tendência era estimular os consumidores a substituir produtos ao invés de

\footnotetext{
31 "But when a new category of objects is consciously designed for disposability, two new parameters must enter the design process. For one thing, does the price of the object reflect its ephemeral character? [...] The second consideration concerns what happens to the disposable article after it has been disposed of. Automobile junkyards follow our highways from coast to coast. And even these appalling smears on the landscape at least have a (painfully slow) rusting process in their favor, so that five or twenty years hence the cars will have turned to dust." (PAPANEK, 1971, p. 94-95)
} 
consertá-los. Como dado atual, uma das conclusões da pesquisa do Idec e da Market Analysis é a de que consumidores que buscam assistência técnica para seus equipamentos quebrados, desistem do conserto geralmente por ele não valer a pena em relação à compra de um novo, sendo neste caso, mais oneroso. "A demora no conserto, a falta de peças e falta de garantia do conserto também são apontados como justificativas para a não contratação do serviço" (IDEC; MARKET ANALYSIS, 2013, p. 39).

- Ostentação e autocomplacência. Enaltecendo os prazeres momentâneos e um entusiasmo por bens materiais, "procuraram encorajar americanos a abandonar suas antiquadas inibições e aprenderem a viver a vida. Tudo isso, esperavam eles, produziriam real disposição para compras" (PACKARD, 1965, p. 151). No mesmo sentido, Whiteley (1993) afirma que "houve um estranho momento em meados dos anos 1960 em que as pessoas pararam de 'precisar' de algo e transformou-se em desejo... Designers tornaram-se mais importantes na produção de 'desejos' do que de 'necessidades', porque passou-se a ter que criar desejo" (WHITELEY, 1993, p. 18). ${ }^{32}$

- Compras a crédito. Para atender os desejos espontâneos dos consumidores, as compras deveriam ser facilitadas, assim o crédito foi também facilitado. A ilusão de quase não precisar de dinheiro "real" para realizar as compras estimulava-as fortemente. Assim, crédito “'instantâneo' e 'pronto' tornaram-se as palavras mágicas para vender tudo, desde refrigerantes, creme batido e tortas de cereja até remédios para dor de cabeça" (PACKARD, 1965, p. 156).

- A publicidade. “Numa economia em crescimento, a publicidade precisa produzir em massa fregueses do mesmo modo como fábricas produzem em massa mercadorias', declarou o diretor da Printer's Ink" (PACKARD, 1965, p. 205).

As duas últimas estratégias têm papel fundamental na manutenção da obsolescência programada, conforme define Padilha (2016): “a publicidade aliada à estratégia da obsolescência programada e às formas de crédito ao consumidor são, atualmente, as principais estratégias da sociedade de consumo que acabam por manter os consumidores na condição de fantoches do consumismo.”

No mesmo sentido, o sociólogo italiano Domenico De Masi (RODA VIVA, 2013) afirma que a publicidade cria esses desejos e os bancos fornecem o crédito necessário para que possam ser satisfeitos. Ele cita os modelos de iPhone (já mencionado como a cena inicial

32 "There was a strange moment around the mid-60s when people stopped needing and need change to want... Designers became more important in producing 'want' products rather than 'need' products, because you have to create desire." (WHITELEY, 1993, p. 18) 
do documentário da BBC) como exemplo de uma das grandes mudanças citadas anteriormente: quando um novo telefone é lançado, a pessoa que tem o velho se sente automaticamente diminuída e antiquada, ainda que não saiba exatamente qual é a vantagem do novo.

Conforme visto anteriormente, todas as estratégias e práticas de consumo listadas por Packard na década de 1960 podem ser identificadas ainda hoje, e por meio delas é possível inferir a existência da obsolescência programada.

Essas estratégias "precisam ser compreendidas porque, para melhor ou para pior, estavam influenciando profundamente o clima em que viveu o povo dos Estados Unidos e, em crescente escala, o povo do resto do mundo ocidental" (PACKARD, 1965, p. 24). Estavam mudando os hábitos das pessoas não só no que diz respeito às compras em si, mas também à maneira de se relacionar em sociedade.

\subsection{Consumismo (ou danos colaterais)}

É falta de realismo supor que todas essas pressões não estão produzindo mudanças em nível mais profundo do que os meros hábitos de consumo. [...] Essas novas pressões estão levando cada vez mais pessoas a acharem as principais satisfações da vida em seu papel consumidor e não em seu papel produtivo. (PACKARD, 1965, p. 221)

Papanek (1971) acreditava que, quando as pessoas são convencidas a jogar fora seus carros antes de se desgastarem, suas roupas para estar de acordo com as tendências da moda ou seus aparelhos eletroeletrônicos sempre que uma nova função é agregada ou um novo modelo lançado, se corre o risco de considerar tudo obsoleto. Tornando descartáveis móveis, veículos, roupas e aparelhos eletrônicos, podemos passar a sentir que as relações pessoais também são descartáveis, e, numa escala global, países e subcontinentes inteiros podem passar também a ser descartáveis. Não valorizamos o que jogamos fora e, quando projetamos coisas para serem descartadas, exercitamos um design descuidado no que diz respeito a fatores de segurança ou mesmo à ideia de alienação ou efemeridade das coisas.

O receio de Papanek se consolidou no que Bauman (2008) chama de "sociedade de consumidores", que, à semelhança da mudança apontada por Whiteley (1993), é o ambiente em que vivemos hoje e que se distingue por uma reconstrução das relações humanas a partir do padrão e à semelhança das relações entre consumidores e os objetos de consumo. Para o autor, essa maneira de se relacionar é um dos “danos colaterais" ou "baixas colaterais" da sociedade de consumidores, assim como a obsolescência programada: 
Entre as maneiras com que o consumidor enfrenta a insatisfação, a principal é descartar os objetos que a causam. A sociedade de consumidores desvaloriza a durabilidade, igualando "velho" a "defasado", impróprio para continuar sendo utilizado e destinado à lata do lixo. A sociedade de consumidores é impensável sem uma florescente indústria de remoção de lixo. Não se espera dos consumidores que jurem lealdade aos objetos que obtêm com a intenção de consumir. (BAUMAN, 2008, p. 31)

Também nesse sentido, no que diz respeito ao design, as mudanças foram profundas, pois a sociedade de consumo foi substituída por uma sociedade consumista, segundo Whiteley (1993). “O primeiro termo baseia-se numa economia de mercado e, por isso, existe há alguns séculos; a sociedade consumista significa um estado avançado da sociedade de consumo e da economia de mercado, no qual a prosperidade individual de uma escala de massa é a força dominante no mercado" (WHITELEY, 1993, p. 16). ${ }^{33}$

A diferença entre consumo e consumismo, segundo Bauman, está na intensidade: enquanto o primeiro ocupa setores pontuais da vida das pessoas como uma atividade trivial, o segundo exerce papel central na sociedade. Em suas palavras, “de uma maneira distinta do consumo, que é basicamente uma característica e uma ocupação dos seres humanos como indivíduos, o consumismo é um atributo da sociedade" (BAUMAN, 2008, p. 41) e traz em suas características uma "obsolescência embutida" dos bens de consumo, pois, "a sociedade de consumidores talvez seja a única na história humana a prometer felicidade na vida terrena, aqui e agora e a cada 'agora' sucessivo" (BAUMAN, 2008, p. 60), uma felicidade instantânea a cada compra que se perpetua no eterno comprar que, em verdade, não satisfaz, pois não traz a felicidade almejada. Para atender a todas as necessidades, impulsos, compulsões e vícios e para manter vivas e renovar as expectativas de felicidade já descreditadas e descartadas, a economia consumista tem de se basear no excesso e no desperdício, encurtando o caminho da loja à lata de lixo. Nesse sentido, conceitos do vocabulário dos advogados como "danos colaterais" ou "vitimas colaterais" estão atualmente sendo empregados para alegar uma falta de intencionalidade nas ações. Trazendo a ideia para o discurso da obsolescência, a questão controversa é se os danos ambientais acarretados por ela são realmente "impossíveis de prever" ou "impossíveis de evitar intencionalmente", uma vez que os objetos são feitos intencionalmente para durar pouco tempo, tornando-se lixo, na maior parte das vezes. Como destacou Bauman, existem razões para suspeitar que o argumento "falta de intencionalidade" é empregado apenas para negar a "cegueira ética" dos processos produtivos na sociedade de consumidores.

\footnotetext{
33 "The implications for design were profound. The consumer society was now being superseded by what I would term the consumerist society. The former term is predicated on a market economy and so has been in existence for some centuries; consumerist society signifies an advanced state of consumer society and the market economy, in which private affluence state of a mass scale is the dominant force in the market place.” (WHITELEY, 1993, p. 16)
} 
Bauman acredita que as relações pessoais atualmente passaram a ser tecidas de acordo com as regras de mercado, e consumir é ao mesmo tempo um direito e um dever na sociedade de consumidores. A partir disso, se estabelece quem está dentro e quem está fora dele; quem compra está dentro, quem não compra está fora.

No mesmo sentido, Whiteley (1993) afirma que nossa sociedade consumista é permeada pelo individualismo ao invés da individualidade, e dessa maneira a sociedade não é superior à soma de suas partes individuais. Os indivíduos, por sua vez, acabam pensando em si mesmo como consumidores, e não como cidadãos. E finalmente o design, liderado pelos consumidores, não oferece visão social nem nenhuma visão da sociedade.

De Masi (RODA VIVA, 2013) alerta também para outro problema importante da nossa sociedade consumista, que diz respeito à distribuição de renda e, para ilustrá-lo, toma como exemplo o caso da empresa Olivetti, que logo após sua fundação limitava o salário do presidente a cinco vezes mais do que um operário, ou seja, o presidente não pode ganhar mais do que o salário de cinco de seus operários. Quando essa proporção é aumentada, além de estimular a desigualdade social, enfraquece o mercado, pois retira dele possíveis consumidores. Segundo De Masi, se o presidente de uma empresa ganha o equivalente a 12 mil operários, isso "tira" do mercado 12 mil pessoas, pois uma pessoa só, na figura do presidente, não vai comprar 12 mil paletós nem 12 mil pares de sapato, e dessa maneira o consumo se reduz.

Numa sociedade que avalia seu sucesso o fracasso pelas estatísticas do PIB (ou seja, a soma total de dinheiro que troca de mãos nas transações de compra e venda), esses consumidores deficientes e defeituosos são descartados por serem perigosos. (BAUMAN, 2008, p. 88)

Nessa mesma perspectiva, Bauman identifica essa desigualdade na maneira como é avaliado o sucesso ou o fracasso de uma sociedade nos dias de hoje. Ficam de fora dela consumidores sem poder de compra. Destaca-se aqui a palavra escolhida: consumidor. Reitera-se também a afirmação, feita por Whiteley (1993), de que a sociedade consumista é composta por consumidores, e não cidadãos e, dessa maneira, o individualismo se sobrepõe à individualidade.

Como foi visto, para além das consequências de geração de lixo e esgotamento de recursos naturais, exploradas na introdução desta dissertação, a obsolescência programada modifica a maneira de consumir e a relação com os produtos, assim como altera também o relacionamento entre integrantes e sociedade como um todo. 


\title{
2.5 A relação entre o design e a obsolescência programada: uma comparação entre a década de 1940, a década de 1970 e conceitos atuais de design
}

A obsolescência programada, como visto anteriormente, tem início com mudanças tecnológicas e em seguida com apelos de consumo da ordem psicológica, apoiados também por uma valorização do estilo, que decorre da obsolescência dos artefatos, da qual ao mesmo tempo se alimenta. Segundo Forty (2007, p. 73), "se quisermos encontrar explicações para as mudanças em design, temos de olhar para além das máquinas e examinar o sistema social em que elas eram usadas" e da mesma maneira "conhecer a amplitude dos diferentes designs era conhecer uma imagem da sociedade" (FORTY, 2007, p. 128).

\begin{abstract}
A atividade do design foi, portanto, de grande ajuda para o desenvolvimento do capitalismo em indústrias que produziam bens de consumo, fornecendo a variedade que permitia aos fabricantes aumentar constantemente suas vendas e seus lucros. Se o design prestou tantos serviços ao capitalismo, o capitalismo não foi menos benéfico para o design. Não somente ele deu origem ao design como uma atividade necessária dentro da divisão do trabalho na manufatura, como seu apetite por novidade e variedade garantia a prosperidade dos designers. O capitalismo pode ter sido muito ruim para muitos ofícios e profissões, erodindo suas habilidades, seu status e suas recompensas, mas o design é uma atividade que ele fez florescer. (FORTY, 2007, p. 124)
\end{abstract}

É interessante comparar a visão de design na bibliografia revista. De um lado, Lippincott com seu livro Design for business, escrito na década de 1940 para guiar homens de negócio neste novo contexto de obsolescência programada, valoriza muito o design e o atrela diretamente ao estilo e ao marketing, conforme seus dizeres: "existe somente uma razão para contratar um desenhista industrial: aumentar as vendas de um produto" (LIPPINCOTT, 1947, p. 21). Ele ainda descreve todas as coisas importantes que um profissional de design pode oferecer: a definição correta da luz, a melhor escolha de cor, tudo com o intuito de aumentar as vendas. Indica até como contratar um designer, quais são as características importantes a serem observadas e as perguntas a serem respondidas por este profissional numa eventual entrevista. É curioso pensar que as definições são de uma época em que a profissão ainda estava crescendo, portanto não era muito popular, e seus atributos, na opinião de Lippincott se relacionavam basicamente com as vendas, e por essa razão estava quase sempre atrelado também à publicidade e ao marketing, pois, segundo o autor, o

principal objetivo do desenhista industrial é criar um artigo com forte apelo de vendas, e ele consegue isso por meio da compreensão das tendências de estilo. [...] Em algum momento o estilo foi usado, quase exclusivamente, na propaganda de roupas femininas, mas hoje aplica-se, quase obri- 
gatoriamente, a itens básicos, como geladeiras, automóveis, rádios, lava-louças, aviões, telefones, torradeiras, móveis, interiores e às embalagens dos produtos. [...] É trabalho do designer relacionar as descobertas do marketing e das pesquisas com consumidor com as de vendas e desenhar produtos que possam ser interpretados pela engenharia de forma inteligente. $O$ resultado deve ser um produto que tenha não só um apelo genuíno de vendas, mas que tenha também a possibilidade de ser fabricado a um preço competitivo com o maquinário disponível. É um axioma da nossa economia atual: não se pode ter produção em massa sem o consumo de massa. Esta afirmação é tão básica que foi muitas vezes negligenciada. No design industrial, no entanto, o artigo deve ser projetado não para se adequar à ideia do artista, mas para atrair o maior número de compradores. Em resumo, desenhista industrial desenha para vendas. (LIPPINCOTT, 1947, p. 19) ${ }^{34}$

Do outro lado da comparação, Papanek valoriza o design no sentido não somente de propor soluções estéticas, mas também para os problemas de sua época. Sua principal missão, segundo o autor, é "transformar o meio ambiente e as ferramentas do homem e, por extensão, o próprio homem" (PAPANEK, 1971, p. 28).

A função do designer é apresentar opções às pessoas. Estas opções deveriam ser reais e significativas, permitindo que as pessoas participassem mais plenamente nas decisões que lhes dizem respeito, e deixando-as comunicar com os designers e arquitetos na procura de soluções para seus próprios problemas, mesmo - quer queiram, quer não - tornando-se os seus próprios designers. (PAPANEK, 2014, p. 64)

É interessante observar que nas duas definições, ainda que diametralmente opostas, o design ocupa lugar de destaque no contexto em que estão inseridas. Nos dois livros há uma ênfase na importância do design no cotidiano das pessoas, pelo simples fato de estarmos rodeados por objetos que foram desenhados. Vale reproduzir um trecho do livro de Lippincott (1947), no qual ele descreve o cotidiano de uma pessoa na sua rotina matinal na década de 1940, mas que valeria também para os dias presentes:

Na sua rotina matinal no banheiro, você usa uma escova de dentes, a qual um designer industrial dedicou muitas horas para definir sua cor, forma e materiais. Você espreme a pasta de dente de um tubo, cuja embalagem é um item importante e que teve muito a ver com a sua escolha de compra. Você olha em um espelho que ilumina seu rosto de maneira completa porque algum

\footnotetext{
34 "His main objective is to create an article of strong sales appeal, and he achieves his end only through the understanding of style trends. Such trends represent the contemporary drift of consumer acceptance. [...] At one time style was used mainly in the merchandising of women's wear, but today it applies almost as forcefully to such basic items as refrigerators, automobiles, radios, dishwashers, airplanes, telephones, toasters, furniture, interiors and packaged products. [...] It is the designer's job to correlate the findings of consumer research and marketing with those of the sales force and to design visually products that may be interpreted intelligently by the engineering staff. The result should be a product that has not only genuine sales appeal but also is capable of being manufactured at a competitive price with the equipment possessed by the plant. It is an axiom of our present day economy that one cannot have mass production luithout mass consumption. This statement is so basic that it has often been overlooked. In industrial design, however, the article must be designed not to suit the idea of the artist, but rather to appeal to the greatest number of buyers. In brief, the industrial designer styles for sales." (LIPPINCOTT, 1947, p. 19)
} 

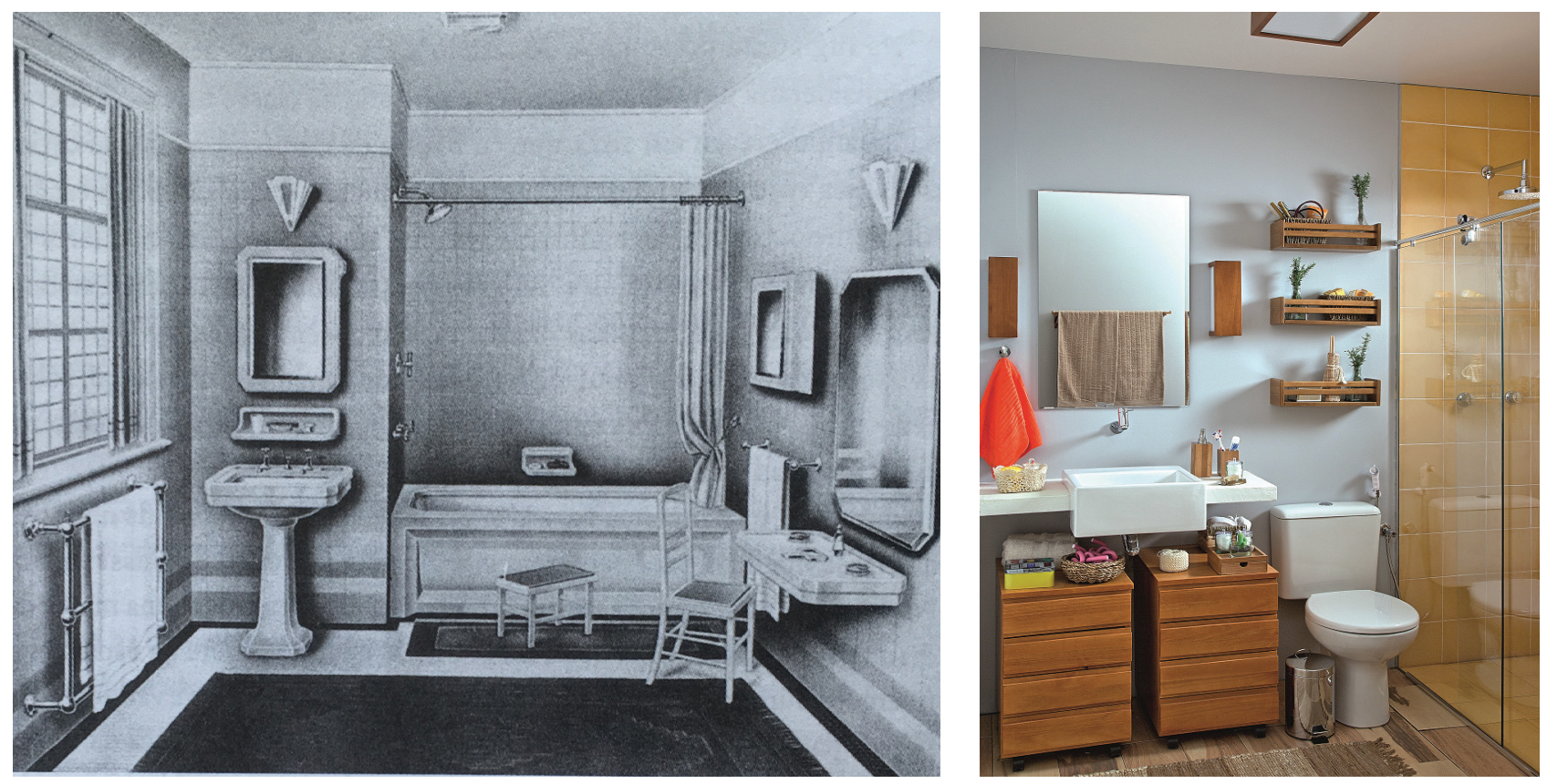

Figura 12. Banheiro na década de 1930. (Fonte: Forty, 2007, p. 228)

Figura 13. Banheiro nos dias de hoje. (Fonte: https://minhacasa.abril.com.br/decoracao/banheiro-elegante-perfeito-para-familia-toda/)

designer industrial projetou os dispositivos elétricos de iluminação para fazê-lo dessa maneira. Seus remédios e artigos de higiene pessoal estão ao alcance da mão porque o desenhista industrial previu o lugar de mais fácil acesso para eles em seu armário de medicamentos. $\mathrm{O}$ desenhista industrial também desenhou sua lâmina de barbear, seja ela elétrica ou convencional de metal. Ele se barbeou com essa lâmina diversas vezes antes que você pudesse fazê-lo, para ver se ela se encaixava na mão com facilidade, para ver como ela deslizava no rosto e para observar o tempo que levou para se barbear. Ele desenhou para ela uma caixa bastante atraente, que provavelmente chamou a atenção de sua tia Susie, e é por isso que ela deu para você no Natal passado. (LIPPINCOTT, 1947, p. 28-29) ${ }^{35}$

Colocado dessa maneira, o design está sempre presente nos objetos de uso cotidiano, podendo ser explorado do ponto de vista das vendas, conforme propõe Lippincott, ou do ponto de vista de mudanças sociais, como propõe Papanek. Como no caso da ener-

\footnotetext{
35 "When you go through the morning routine in the bathroom, you use a toothbrush to which the industrial designer has given many hours of careful thought about its color, shape and materials. You squeeze toothpaste from a tube whose packaging is such an important item that it had much to do with your buying that particular toothpaste in the first place. You gaze into a mirror, which illuminates your face completely because some industrial designer has devised the lighting fixtures to do it that way. Your medicines and toiletries are easily accessible because the industrial designer foresaw the handiest spot for them in your medicine cabinet. The industrial designer also styled your razor, whether electric or steel blade type. He shaved with that razor many times before you did, to see that it fitted the hand easily, to see how it lay on your cheek, and to note how fast it shaved. He designed an attractive box for it which probably caught the eye of your Aunt Susie, and that's why she gave it to you last Christmas. (LIPPINCOTT, 1947, p. 28-29)
} 
gia elétrica citado anteriormente, o design colabora na aceitação dos produtos que passam a ser elétricos, e não mais a gás ou a carvão. $O$ rádio é um outro bom exemplo do design nessa aceitação do novo: ele primeiro foi desenhado como mobília, na forma de uma poltrona, cômoda ou criado mudo; em seguida destacou-se da mobília, mas para esconder seus sistemas passou a ser desenhado em uma caixa que, por meio de seu design, indicava seu pertencimento a um mundo melhor, ao mundo do futuro; passando por fim a ser portátil com sistemas modernos de microchips (FORTY, 2007).

Outro exemplo que vale ser citado é o do conceituado designer Raymond Loewy, que redesenhou uma geladeira para a Sears, Roebuck and Company em 1935, época em que a ideia de higiene passou a ter grande importância, sendo ensinado nas escolas, por exemplo, maneiras corretas de limpar a casa que passou a ter que ser mais "limpável". Novos materiais começaram a ser empregados, tais como o aço cromado e o vidro, que foram bem recebidos nos escritórios, por exemplo. Passou-se a empregar menos tecidos, menos madeira e menos relevo ornamental à decoração da casa, o que acabou por alterar todo o mobiliário tanto nos escritórios como nas casas das pessoas na década de 1930, na Inglaterra. No caso da geladeira, Raymond Loewy optou por tirá-la da caixa de madeira em que era vendida, transformando-a numa caixa branca, que traduzia com maior clareza o conceito de higiene vigente. A moda também aderiu a roupas mais simples, sem tantos babados. Aspiradores de pó venderam muito e, como o caso da indústria automobilística descrito anteriormente, se valeram da experiência automobilística de obsolescência, para aumentar ainda mais suas vendas.

Certo ou errado, o fato é que, nos artefatos das sociedades industriais, o design foi empregado habitualmente para disfarçar ou mudar sua verdadeira natureza e enganar nosso senso cronológico. A fim de compreender o design, devemos reconhecer que seus poderes de disfarçar, esconder e transformar foram essenciais para o progresso das sociedades industriais modernas. (FORTY, 2007, p. 22)

Colaborando para a aceitação de novos conceitos ou tecnologias, o design por vezes acaba por abandonar as características de diálogo com a sociedade propostas por Papanek. Até porque, como bem esclarece Forty, o design - e as ideias e soluções criativas dos designers - é consequência de momentos da sociedade, mas os empresários também são protagonistas das decisões tomadas. "É o empresário e não o designer que decide qual design encarna satisfatoriamente as ideias necessárias para o sucesso do produto e que se ajusta melhor às condições materiais de produção" (FORTY, 2007, p. 325). O autor acredita que é o design - e não o designer - que é capaz de transformar ideias sobre o mundo, assim como as relações sociais, por meio da forma dos objetos. 
Nenhum design funciona, exceto se encarna ideias que são comuns às pessoas para as quais o objeto se destina. Representar o design como puro ato de criatividade de indivíduos [...] realça temporariamente a importância dos designers, mas, em última análise, apenas degrada o design ao separá-lo do funcionamento da sociedade. [...] Somente com a investigação desse processo (de transformação das ideias do mundo e das relações sociais) e com a mudança de nosso foco para longe da figura do designer é que poderemos compreender adequadamente $o$ que é design e apreciar quão importante ele tem sido para representar as ideias e as crenças por meio das quais assimilamos os fatos materiais do cotidiano e nos ajustamos a eles. (FORTY, 2007, p. 330)

Da mesma maneira que Forty e Papanek acreditam no design como uma profissão capaz de pensar em produtos conectados com seu contexto e pensados de maneira sistêmica, Bonsiepe acredita que

o design se distanciou cada vez mais da ideia de "solução inteligente de problemas" e se aproximou do efêmero, da moda, do obsoletismo rápido - a essência da moda é a obsolescência rápida -, do jogo estético-formal, da glamourização do mundo dos objetos. Frequentemente, hoje em dia, design é associado a objetos caros, pouco práticos, divertidos, com formas rebuscadas e gamas cromáticas chamativas. A hipertrofia dos aspectos da moda, por sua vez, reflete-se nos meios de comunicação de massa, em sua incessante busca pelo novo. (BONSIEPE, 2011, p. 18)

Para Papanek (2014, p. 10), o designer deve ter, entre outras aptidões, a capacidade de investigar, organizar, inovar, descobrir soluções para os problemas recém-surgidos e prever as consequências ambientais, ecológicas, econômicas e políticas provocadas pelo design. Nesse sentido, o projeto do produto deve prever todas as etapas do seu ciclo de vida levando em consideração o contexto atual de esgotamento de recursos naturais e alta geração de lixo. Se as etapas iniciais do desenvolvimento de um produto estiverem alinhadas com a parte final de seu ciclo, mais fácil será cumprir as responsabilidades listadas na Política Nacional de Resíduos Sólidos, exposta na introdução deste estudo. Para Manzini (2008), a etapa de desenvolvimento de produtos de design deve pensar em termos de soluções para promover uma abordagem sistêmica que considere planejamento, produção execução, uso e descarte final.

Papanek (2014, p. 63) acredita que o design pode ter papel fundamental no desenvolvimento de novos estilos de vida necessários para a mudança do contexto atual, e "serão necessárias mudanças nos estilos de vida para que muitas das mudanças mais radicais" possam acontecer. Entretanto, Bonsiepe (2011, p. 15) constata que "se dermos uma olhada panorâmica no discurso atual do design ou no discurso projetual conceito que prefere utilizar - , constatamos uma surpreendente ausência de questionamentos sobre a atividade projetual”. 
[...] cabe ao designer intervir na realidade com atos projetuais, superando as dificuldades e não se contentando apenas com uma postura crítica frente à realidade e persistindo nessa posição. Afinal, projetar, introduzindo as mudanças necessárias, significa ter a predisposição para mudar a realidade sem se distanciar dela. (BONSIEPE, 2011, p. 36-37)

Segundo Whiteley (1993), o design deixou de se concentrar nos produtos para se concentrar no mercado. Ele utiliza os termos product-lead design e consumer ou marketled design para nomear esta mudança no design, complementando que o segundo é parte de ideologia econômica, social e política. Porém, da mesma maneira que Bonsiepe, acredita que

A profissão de design precisa ser ao mesmo tempo introspectiva e conectada com o que se passa no exterior. Deve observar suas práticas e valores e suas implicações; e deve olhar para a condição da sociedade e do mundo. Os designers não podem mais se refugiar da responsabilidade de suas próprias ações e criar continuamente novas embalagens para bens de consumo antigos em um momento em que questões sobre consumo e sua relação com os recursos naturais e a energia do mundo é que precisam urgentemente de atenção. (WHITELEY, 1993) ${ }^{36}$

Um exemplo contemporâneo de que a ênfase do design acaba limitando seu campo de atuação a objetos com ambições comerciais ou estéticas e quase nunca sociais pode ser demonstrado pela pesquisa de doutorado de Frank Anthony Barral Dodd, apresentado na FAU-USP, na qual o pesquisador fez uma análise qualitativa dos produtos de design presentes nos livros de design brasileiros no ano de 2011. Sua pesquisa procurou demonstrar quantitativamente que os objetos com maior incidência nos livros não representam o campo do design, sendo esta uma prática nociva para o campo, segundo descreve:

A falta de informação sobre o campo do design é algo negativo, mas apresentar nos meios de comunicação uma pequena parte do cenário total do campo como se fosse a imagem completa é mais negativo porque gera desinformação, já que tal proposição se faz acompanhar, implicitamente, da errônea visão de que o que não está apresentado não faz parte do universo representado (o campo do design). [...] Ou seja, de novo, nos encontramos diante de uma divulgação parcial do design, que resulta em um ciclo que se realimenta: cobra-se certo perfil do design e do designer, porque este perfil é aquele majoritariamente divulgado e que, por ser mais familiar, é o que passa a ser esperado pelo público. (DODD, 2011, p. 33-34)

Ainda são pouco frequentes iniciativas como a da exposição, que virou publicação, Design for the other $90 \%$, que apresenta projetos com clara função social, tais como o re-

\footnotetext{
36 "The design profession needs to be both introspective and outward-looking. It must look at its practices and values, and their implications; and it must look at the condition of society and the world. Designers can no longer take refuge from responsibility for their own actions and continually repackage the same old type of consumer goods at a time when issues about consuming and its relationship to the world's resources and energy need urgently to be.” (WHITELEY, 1993)
} 
cipiente para transporte de água, desenvolvido para países africanos que sofrem com a seca, que tem a forma de uma roda (ou um biscoito redondo com um furo no meio) e no meio da qual um fio auxilia seu transporte. O recipiente permite que se transporte uma grande quantidade de água com pouco esforço humano, substituindo as latas e baldes antes carregadas na cabeça das pessoas ou grandes garrafas carregadas nas mãos. ${ }^{37}$

É necessária uma conscientização geral do mercado, e novas medidas devem ser avaliadas no desenvolvimento de produtos. Como veremos no exemplo da BMW no próximo item, é possível uma empresa seguir a sua função social, adotando uma maior responsabilidade ambiental no desenvolvimento de seus produtos.

Muitos autores tratam do design relacionado com a reciclagem por meio de projetos que lidam com as "sobras", outros por meio da sustentabilidade, na utilização de materiais recicláveis. Mas na realidade, $3 \%$ por cento do lixo reciclável gerado no Brasil é de fato reciclado (fonte). Isso quer dizer que produzir algo que seja reciclável não garante que será de fato será reciclado. Então, por que não pensar no ciclo completo de produção dos produtos, como é uma premissa antiga do design, reafirmada por Annie Leonard no filme Story of stuff? ${ }^{38}$. Por que, ao invés de pensar no ciclo completo no sentido do descarte, não podemos pensar em não haver descarte ou desperdício de matéria-prima, como a base da economia circular proposta por Michael Braungart, criador do conceito do berço ao berço, em que os resíduos gerados por uma indústria transformam-se em matéria-prima para outras?

\subsection{A relação entre o design e a obsolescência programada: casos contemporâneos}

Um exemplo de desenvolvimento de projeto que considera todas as etapas do ciclo de vida de um produto e a responsabilidade ambiental é o carro da BMW. Segundo o site da empresa, seus carros são feitos de maneira a serem recebidos e reciclados no final de seu ciclo de vida. Assegura ainda que os veículos poderão ser rápida e eficientemente reciclados, pois são fabricados com uma gama reduzida de materiais, montados de maneira a serem separados. Além disso, a empresa conta com o envolvimento de empresas especializadas em reciclagem de veículos em fim de vida. "As quatro etapas de processamento ecológico de veículos em fim de vida são: entrega controlada,

37 Disponível em: http://www.designother9o.org. Acesso em: 15 ago. 2017.

${ }^{38}$ Disponível em: http://storyofstuff.org/movies/story-of-stuff. Acesso em: 15 ago. 2017. 

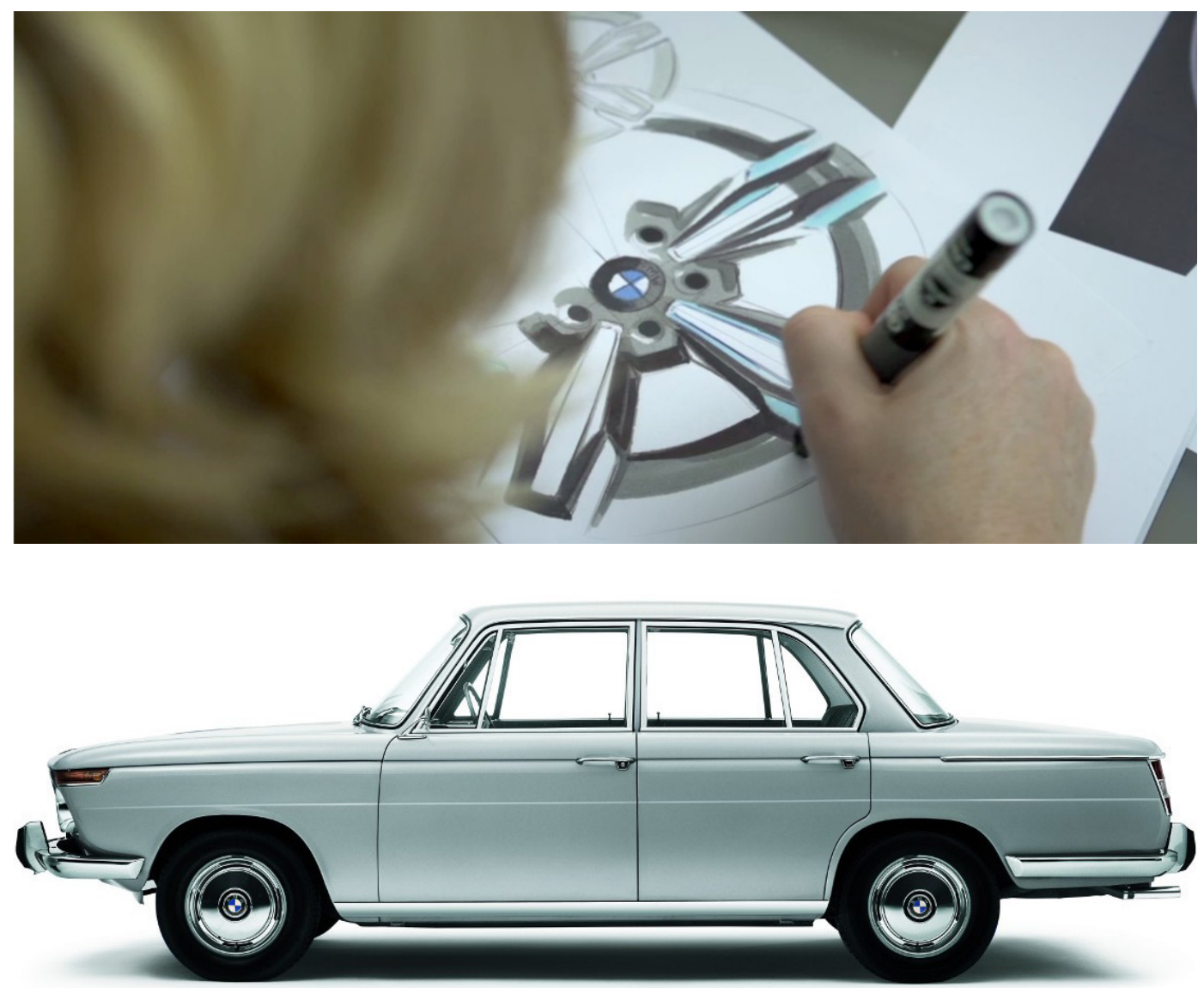

Figura 14. Imagens extraídas do site da BMW (Fonte: www.bmw.pt)

pré-tratamento, desmontagem e reciclagem do veículo residual" (RECICLAGEM NA BMW, 2016). No site também está anunciado o engajamento da empresa com a implantação da Política Nacional de Resíduos Sólidos, que futuramente exigirá que 85\% do peso de um veículo em fim de vida devem ser reutilizados na forma atual dos componentes ou como material para novas peças.

Essa meta foi, há muito, alcançada para as peças em metal. $\mathrm{O}$ vidro e muitos dos plásticos já podem ser economicamente recuperados. O BMW Group representou um papel vital neste processo criando novas técnicas. Os motores desmontados por técnicos especializados podem ser recondicionados e reutilizados para o seu propósito original, como uma forma de reciclagem de topo. Após desmontagem, os veículos residuais são enviados para uma empresa de trituração. Estas instalações cortam a carroçaria residual em peças do tamanho de uma mão e separam-nas. Plásticos, têxteis, ferro e metais não ferrosos são reutilizados. (RECICLAGEM NA BMW, 2016)

Nesse sentido, o design tem um papel fundamental no início do processo, pois pensando em materiais diferentes unidos por peças, e não por soldagem, aumentamos a chance de sua reciclagem. E porque não ir além, como no caso da BMW, e considerar 
que a matéria-prima volta para o início do processo depois do descarte do carro e pode voltar a ser um carro?

Essas iniciativas têm um impacto no início do processo de projeto de um produto, pois a escolha dos materiais e a maneira como eles serão unidos influencia diretamente na possibilidade de ele ser reciclado ou reutilizado. No sentido oposto ao dos carros da BMW, Ficou famoso o caso das cápsulas de Nespresso, feitas em metal com laminação de plástico. A fusão dos materiais torna impossível sua reciclagem.

Seja por empregar materiais reciclados, incorporando sua reciclagem no ciclo do produto, seja por iniciativas privadas, a valorização do conserto e do compartilhamento de produtos ganham força, e atualmente podem ser encontradas pelo mundo diversas iniciativas que seguem essa tendência, tais como:

- As medalhas das próximas Olimpíadas, Tóquio 2020, serão feitas a partir da reciclagem do ouro e da prata de celulares. Foram instalados na cidade diversos pontos de coleta de celulares antigos, nos quais a população pode descartar seu telefone antigo (OS CELULARES ANTIGOS, 2017).

- Na Alemanha, o sistema de reciclagem Pfand funciona como se as pessoas pagassem um imposto pelas embalagens, mas ao retorná-las aos postos de coleta espalhados em mercados, recebem seu dinheiro de volta. Os valores do conteúdo e embalagem são especificados no produto, facilitando o discernimento dos valores.

- A Suécia tem um projeto de lei para reduzir os impostos sobre serviços, como uma maneira de estimar o conserto das coisas, e não seu consumo e descarte (BARBOSA, 2016). Há também um shopping dedicado exclusivamente à venda de materiais reutilizados (SUÉCIA INAGURA, 2016).

- O projeto holandês Repair Café ${ }^{39}$ tem diversas unidades pelo mundo (incluindo uma em Porto Alegre), onde, basicamente, trabalha-se de maneira colaborativa. Os cafés, que disponibilizam ferramentas variadas, são frequentados por voluntários com conhecimentos também variados e por proprietários de produtos com defeito. Essa junção de conhecimentos traz de volta à vida equipamentos que antes virariam lixo.

No Brasil, houve recentemente a implementação do projeto piloto Descarte On, que aplicou a logística reversa de resíduos elétricos e eletrônicos (REEE). A iniciativa contou com a parceria de lojas de varejo e empresas de reciclagem na região da

${ }^{39} \mathrm{https} / / /$ repaircafe.org/en/about. 
Lapa, em São Paulo. Entre abril e dezembro de 2016, o projeto coletou 3.781 produtos eletroeletrônicos de pequeno e médio porte (até $50 \times 60 \times 75 \mathrm{~cm}$ ), num equivalente de 4.050,02 quilogramas, e dezenove unidades de eletroeletrônicos de grande porte (televisão, geladeira/freezer, fogão, máquina de lavar/secadora e ar-condicionado), num equivalente de $873,4 \mathrm{~kg}$. Simultaneamente à coleta, foram realizadas pesquisas com os consumidores, que indicaram grande receptividade a esse tipo de inciativa, porém pouco conhecimento sobre o tema do correto descarte e tratamento de eletroeletrônicos.

No mesmo sentido, vale citar também a iniciativa da loja Magazine Luiza que passou a aceitar os celulares usados de seus consumidores, oferecendo um desconto na compra de um novo e reparando o equipamento antigo de maneira que ele possa ser revendido na condição de novo.

Uma pesquisa de mestrado realizada em $2010^{40}$ aponta para altas taxas de descarte de celulares e baixos índices de reciclagem, refletindo uma falta de conscientização dos usuários, uma ausência de mecanismos de regulação que obriguem empresas e consumidores a adotar procedimentos de coleta e destinação, ou seja, uma falta de articulação das várias esferas da sociedade em relação ao problema do lixo eletrônico. A dissertação, intitulada Design e flexibilidade: estratégias para o gerenciamento da obsolescência de telefones celulares, procurou delinear estratégias de design voltadas ao gerenciamento da obsolescência de telefones celulares, por meio de entrevistas com usuários de telefonia móvel. Suas conclusões apontam para a simplificação dos aparelhos, pois "muitos usuários não utilizam todos os recursos oferecidos por considerá-los complexos demais, o que não raro acarreta problemas de usabilidade, além de desperdício de energia e material” (ZACAR, 2010, p. 149) e para a possibilidade de atualização dos aparelhos, conforme descreve:

[...] O desenvolvimento de aparelhos com funções de uso mais simples seria uma alternativa interessante, facilitando o manuseio, manutenção e reparo dos celulares. [...] Alguns usuários fizeram uma relação entre o excesso de funções agregadas e o estrago e o fim da vida útil dos produtos, situação agravada pelo fato de que mandar consertar o aparelho geralmente não compensa financeiramente. [...] A possibilidade de atualização se torna especialmente válida para aqueles usuários que possuem grande interesse por inovações tecnológicas e mais sujeitos à percepção de obsolescência tecnológica. Assim, essa estratégia poderia minimizar a frustração que alguns participantes relataram sentir em relação à dificuldade de acompanhar as inovações tecnológicas. Salienta-se que alguns usuários demonstraram ter necessidade de se mante-

$4^{40}$ Pesquisa realizada por Cláudia Regina Hasegawa Zacar no Programa de Pós-graduação em Design da Universidade Federal do Paraná, a única pesquisa encontrada relacionada diretamente com o tema da obsolescência programada na área de design. 
rem atualizados até mesmo por questões simbólicas, como as relacionadas à imagem pessoal, status, etc. Esta estratégia facilitaria, desta forma, a manutenção do sentimento de atualização e vanguarda, por vezes tão almejado. (ZACAR, 2010, p. 149-152)

O planejamento do pós-uso dos telefones celulares e o estudo de estratégias que contribuam para minimizar a quantidade de aparelhos descartados e, consequentemente, seus efeitos nocivos, são, portanto, pontos a serem considerados no projeto de telefones celulares, segundo a conclusão da pesquisa de Zacar (2010).

\subsection{Futuros possíveis}

Alguns caminhos sugeridos por Packard consideram a diminuição da carga horária dos trabalhadores, que produziriam menos e consumiriam menos. Haveria com isso também uma diminuição na produção de utensílios. Outro caminho, parecido com esse, seria o de rebaixar um pouco a economia, fixando um nível de vida mais baixo. De qualquer maneira, Packard acredita que, para descontinuar a sociedade de desperdício que vivemos, sua razão de ser, que é a de crescimento constante, deve ser reavaliada.

\footnotetext{
E poucos consideram que, embora talvez sejam necessárias aos Estados Unidos algumas espécies selecionadas de crescimento, outras espécies são indesejáveis ou produzirão apenas superabundância. Admite-se simplesmente que todo crescimento é bom. Crescimento está se tornando rapidamente numa palavra sagrada, ao lado de Democracia e Pátria. [...] Em meados de 1960, notícias de Washington revelavam haver, no governo, forte impressão de que deviam ser feitas concessões mais liberais para a obsolescência do equipamento comercial a fim fomentar o crescimento econômico, permitindo a isenção mais rápida de impostos sobre o equipamento existente. (PACKARD, 1965, p. 21)
}

Contemporâneo de Papanek, Packard propunha já na década de 1960 soluções na direção de uma diminuição de crescimento, sendo uma delas a diminuição do consumo e aumento o compartilhamento de bens, através de sua locação, por exemplo, pois, neste caso, o produtor, sabendo que seu produto seria alugado, teria muito interesse em que ele fosse durável, "especialmente se o aluguel fosse feito por ele próprio ou por seus revendedores. Ficaria obcecado com a ideia de desenho simples a fim de reduzir suas despesas com manutenção" (PACKARD, 1965, p. 262). Além de reduzir o consumo, o descarte também seria evitado, uma vez que o produto seria sempre do produtor.

A maneira mais fácil de poupar recursos naturais e energia e reduzir o desperdício é usar menos. Esta afirmação é tão simples que chega a parecer banal - no entanto, pode servir de orientação. Igualmente implícita está a ideia de consumir menos, comprar menos, viver com o que já temos até mesmo, por vezes, livrarmo-nos de todas as engenhocas e duplicados desnecessários que atra- 
vancam horrivelmente as nossas vidas. Tudo isto é apenas uma questão de bom senso; contudo é uma abordagem à vida que parece bastante rara atualmente. (PAPANEK, 2014, p. 205)

Whiteley (1993) também questiona a ideia de crescimento diretamente ligado ao consumo de massas. Segundo o autor, depois da grande discussão levantada nos artigos de jornais e revistas na década de 1970, "a conversa sobre "obsolescência planejada" pode ter sido discretamente descartada, porém a ideologia da economia de alto consumo não foi fundamentalmente questionada nem seriamente revisada" (WHITELEY, 1993, p. 44). ${ }^{41}$

No mesmo sentido, para o pensador e sociólogo italiano Domenico De Masi (RODA VIVA, 2013), o grande inimigo do capitalismo "real", que se pratica hoje nos Estados Unidos e em outras partes do mundo, é o capitalismo doente dominante neste momento, no qual a obsolescência programada tem papel de destaque. Em sua opinião, o capitalismo sempre partiu de pressupostos que deveriam ser colocados em questão atualmente, entre eles os de que:

- O crescimento é eterno, infinito. Isso fez com que o capitalismo nunca se confrontasse com a finitude das matérias-primas, tratando água, oxigênio e todas as matérias -primas como infinitas.

- Os seres humanos podem consumir infinitamente, e a publicidade induz a necessidades sempre maiores, auxiliadas pelos bancos, que as financiam. Segundo o sociólogo, os produtos são cada vez mais frágeis, assim temos que os substituir e os renovar constantemente.

Nas palavras de alguém que vive e pensa o mundo na década de 2010, Annie Leonard, ambientalista e autora do livro The story of stuff, numa entrevista concedida para o jornal $O$ Globo em 2012, ao ser perguntada se nossa sociedade está mesmo passando por um momento de mudança de paradigma e de que maneira a economia global pode se adaptar, explica que pessoas de todos os países ricos do mundo começam a reconsiderar suas prioridades: aprender a viver melhor com menos e construir redes de compartilhamento de coisas.

Muitas pessoas começam a se sentir sufocadas no meio de um oceano de coisas. Nossas casas estão cheias. Nossas garagens estão lotadas. Passamos nosso tempo livre comprando, arrumando as muitas coisas que compramos. Temos mais coisas, porém, menos amigos do que as gerações anteriores. Estamos nos tornando socialmente isolados e solitários. Por isso, muita

41 "However, while in polite professional circles, talk of 'planned obsolescence' may have been discretely discarded, the ideology of the high consumption economy was neither fundamentally questioned nor seriously revised.” (WHITELEY, 1993, p. 44) 
gente começa a perceber que as coisas mais importantes na nossa vida não são coisas materiais. Temos um excesso de coisas e um déficit do que realmente importa: tempo para lazer, para vida em comunidade, senso de significado em nossas vidas. (citado em AZEVEDO, 2012).

No mesmo sentido, De Masi (RODA VIVA, 2013) afirma que teremos que repensar todo o modelo que foi adotado. O sociólogo italiano acredita que o Brasil tem as condições de propor um modelo próprio de economia, pois, apesar da grande diferença entre ricos e pobres, é uma democracia completa, como não se vê em outras partes do mundo. Em seu entendimento, em uma democracia completa há um crescimento da receita, há uma diminuição progressiva da diferença entre ricos e pobres e há uma convivência pacífica entre os integrantes da sociedade e com todos os países com os quais tem divisa territorial.

\footnotetext{
Nós não temos hoje um problema de retocar levemente nosso modelo de vida, nós temos um problema novo, inédito, extraordinário, de criar um novo modelo global. Este é o novo grande desafio da humanidade, os modelos existentes estão todos em crise, não há um modelo que não esteja em crise. (RODA VIVA, 2013)
}

Papanek aponta o design como determinante na mudança do uso individual para o uso coletivo dos utensílios, pois isso deverá levar a uma nova estética, baseada em princípios funcionais e ecológicos.

\footnotetext{
Continuamos à procura de um novo sentido estético baseado na realidade. A preocupação com o ambiente e com os desfavorecidos da nossa sociedade é a base mais profunda e poderosa que deve dar forma ao design. Pode, efetivamente, desenvolver os novos estilos de que necessitamos tão desesperadamente. Têm de ser inventadas e concebidas tecnologias inteiras, baseadas em fontes de energia alternativas. Serão necessárias mudanças nos estilos de vida para que muitas das mudanças mais radicais possam ser aceitas. (PAPANEK, 2014, p. 63)
}

Para Packard (1965), seria desejável também que o consumidor procurasse saber mais sobre a armadilha da obsolescência programada e se tornasse um consumidor mais consciente, exigindo dos produtores que acentuem a função, e não a moda. Consumidores que comprassem produtos com funcionamento comprovadamente satisfatório, produtos básicos em lugar de outros cheios de acessórios desnecessários e produtos que oferecessem condições de manutenção, tal qual no tempo de Henry Ford - que nos anos 1910 e 1920 vendia seus carros junto com uma caixa de ferramentas, para que o usuário pudesse consertar seu próprio veículo, e acreditava que só poderia vender algo que fosse durável. No mesmo sentido, Papanek propõe um "design para desmontar", pois isso pode fazer "com que o utilizador não só adquira um conhecimento mais profundo sobre o aparelho, mas também se torne mais crítico na distinção entre o que é necessário e o que é superficial" (PAPANEK, 2014, p. 226). 
Parece urgente que alguém com autoridade na nação comece a olhar um século à frente na avaliação dos recursos materiais e energia disponíveis e comece a canalizar o uso de ambos nessa conformidade. É possível fazer muito mais do que está sendo feito no sentido de reaproveitar sucata, desenvolver substitutos [...], reduzir o desperdício tanto na mineração como no uso de recursos e encontrar para a necessidade de atividade econômica da nação válvulas que poupem os recursos de suprimento inteiro escasso. (PACKARD, 1965, p. 261)

Leis e propostas contemporâneas transformaram em realidade as ideias de Packard, através, por exemplo, da Política Nacional de Resíduos Sólidos em vigor no Brasil desde 2010, que determina diretrizes para a gestão integrada e o gerenciamento de resíduos sólidos no país, responsabilizando produtores e consumidores pelos materiais produzidos e descartados.

Mais cedo ou mais tarde, a nação terá de aprender a viver dentro de seus meios e acertar o passo para a longa marcha. E quanto mais tarde for aprendido esse fato, tanto menos numerosas e mais desagradáveis serão as alternativas restantes. (PACKARD, 1965, p. 258)

No mesmo sentido, Annie Leonard afirma que um desastre nos espera se tentarmos continuar com o modelo atual indefinidamente. "A questão não é se a economia irá se adaptar. Mas como ela fará isso". Para a ativista, não é possível mantermos nosso ritmo de consumo atual. "Vamos mudar por vontade própria e estratégia ou devido a um desastre. Eu prefiro que mudemos por estratégia e acho que já começamos” (citado em AZEVEDO, 2012).

Mais do que apenas discutirmos os 3R (reduzir, reaproveitar e reciclar), que são importantes, repensar o modelo de crescimento econômico que temos seguido nos últimos 200 anos é urgente. Os franceses, com o economista Serge Latouche à frente, defendem um movimento que cresce a cada ano no mundo: o decrescimento econômico. Outros, como Michael Löwy, defendem o ecossocialismo como parte do otimismo da vontade. Para ele, o ecossocialismo é tanto uma crítica aos modelos de socialismo não ecológicos quanto aos modelos ecológicos sem socialismo. O ecossocialismo faz uma crítica ao ecologismo de mercado. O modelo de produção e consumo vigentes no capitalismo atual é incompatível com a preservação do meio ambiente. Qualquer solução proposta dentro dessa ordem será apenas paliativa, o que não deixa de ser importante, mas temos que ser honestos e assumirmos sua insuficiência. (PADILHA, 2016, p. 48)

As consequências sociais e materiais da obsolescência programada começaram a ser identificadas nos anos que antecederam a publicação do livro de Packard (1965), e questionamentos ao redor do "crescimentismo" (nas palavras de Packard), e das estratégias adotadas para alcançá-lo começam a surgir, encontrando ecos e continuidades nos dias de hoje. 
Packard coloca em questão em seu livro a premissa de que todo crescimento é bom, De Masi por sua vez, relaciona o crescimento com o esgotamento dos recursos naturais, alegando que a resposta está dada: há um limite natural, os recursos começam a se esgotar. Questiona também o consumo eterno, segundo ele, premissa do capitalismo "real".

A ambientalista Annie Leonard também aponta os males do excesso causado pela obsolescência programada, bem como uma tomada de consciência que começa a surgir em prol de uma coletividade.

Da mesma maneira, as soluções propostas na década de 1960 e nos dias de hoje se assemelham: o compartilhamento de bens ao invés da compra; a simplificação dos utensílios proporcionando conhecimento dos proprietários sobre sua montagem e sobre sua verdadeira utilidade, o que vai contra a dificuldade de manutenção relatada nos dois períodos analisados.

Whiteley afirma que "assim como o green design e os movimentos de consumo ético demonstram, a mudança é possível; mas a precondição essencial para que isso aconteça é a consciência da situação atual" (WHITELEY, 1993, p. 37)..$^{42}$

O sucesso de iniciativas como o Airbnb ${ }^{43}$ e Uber ${ }^{44}$ também ilustram uma mudança na maneira como nos relacionamos com os objetos nos dias de hoje. Ainda que controversas, pois se inserem num mercado de livre concorrência e de economia colaborativa, essas iniciativas partem da ideia de compartilhamento de bens, e por essa razão é possível traçar um paralelo entre elas e algumas das ideias sugeridas na revisão da literatura como caminhos possíveis. Elas também apontam para um mercado que se abre para esse tipo de consumo.

De uma maneira geral, observa-se que estamos frente a uma nova mudança no que diz respeito à produção, consumo e uso dos artefatos. $\mathrm{E}$ da mesma maneira que a obsolescência programada surgiu para salvar a economia americana, essa nova mudança traz, junto com a salvação, mudanças que afetaram profundamente a maneira como vivemos.

\footnotetext{
42 "As the green design and ethical consuming movements have demonstrated, change is possible; but an essential precondition is an awareness of the current situation.” (WHITELEY, 1993, p. 37)

43 Rede de aluguel de imóveis, na qual proprietários alugam seus apartamentos e casas inteiros ou apenas parte deles. Tem como slogan "uma comunidade baseada em trocas" e começou, coincidentemente, com dois designers.

${ }^{44}$ Rede de transporte, que coloca os usuários em contato direto com condutores de automóveis, através de um aplicativo de celular.
} 



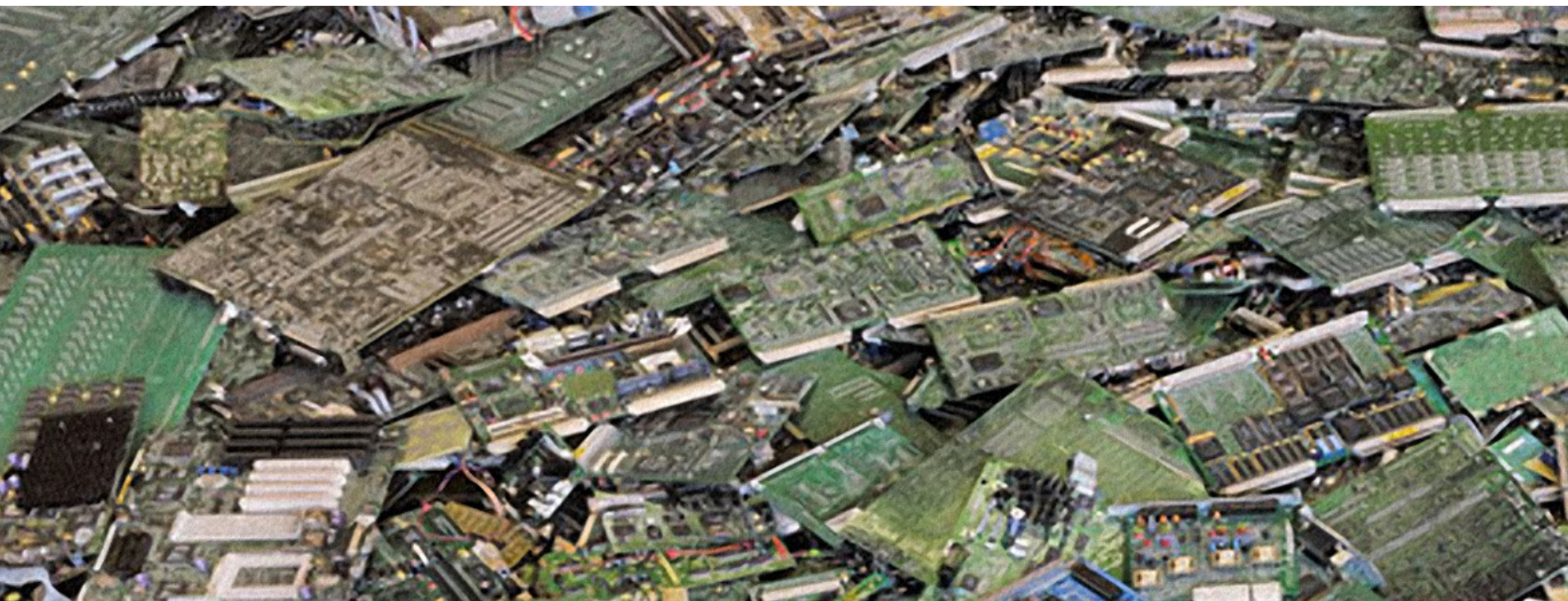

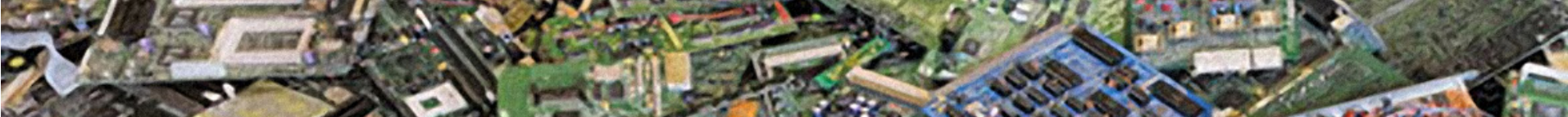

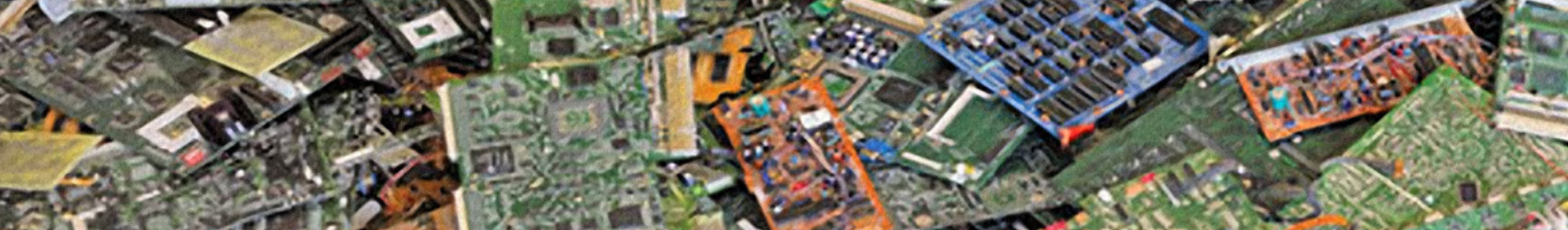

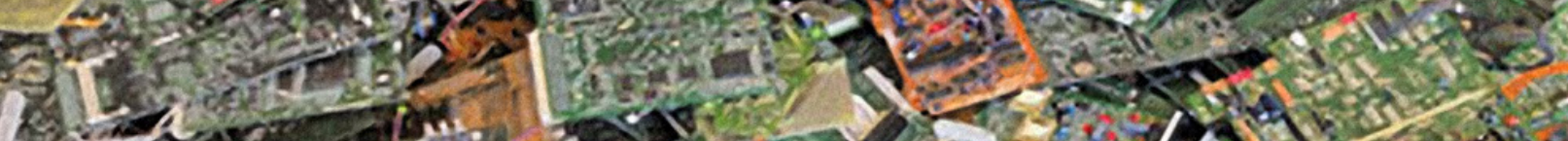

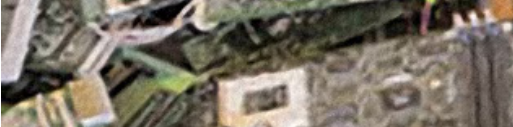

\section{- tra} 1.

$\int_{0} \operatorname{los}_{3}$

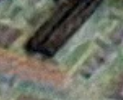

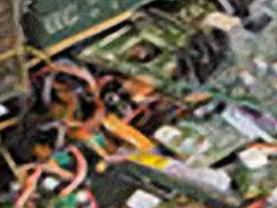

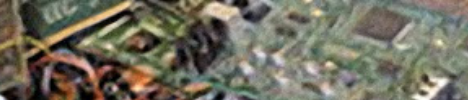

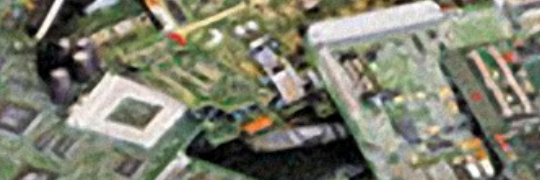

$-200$

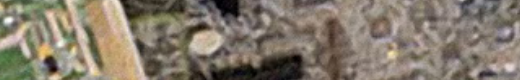

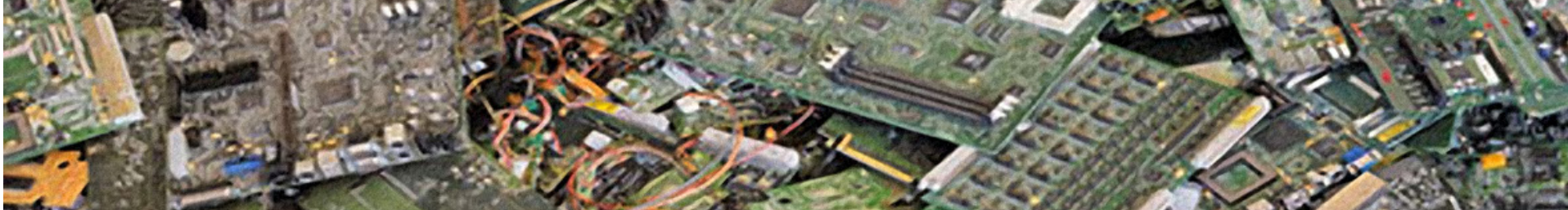

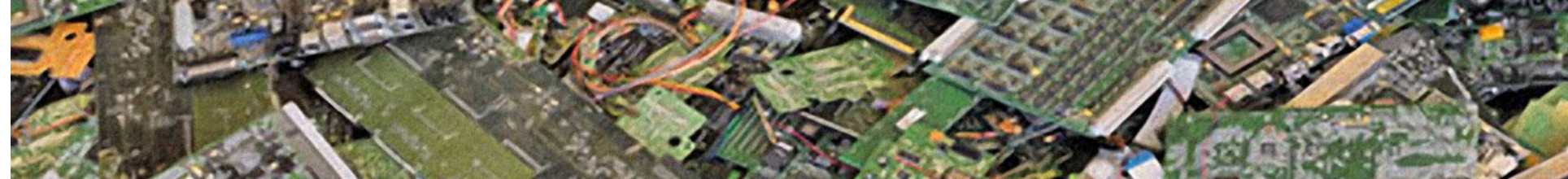

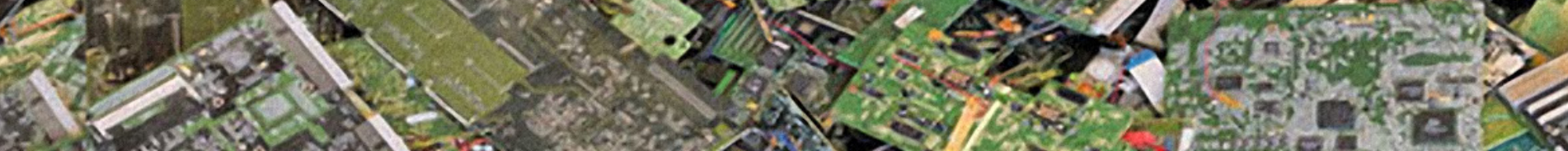

4. 25.

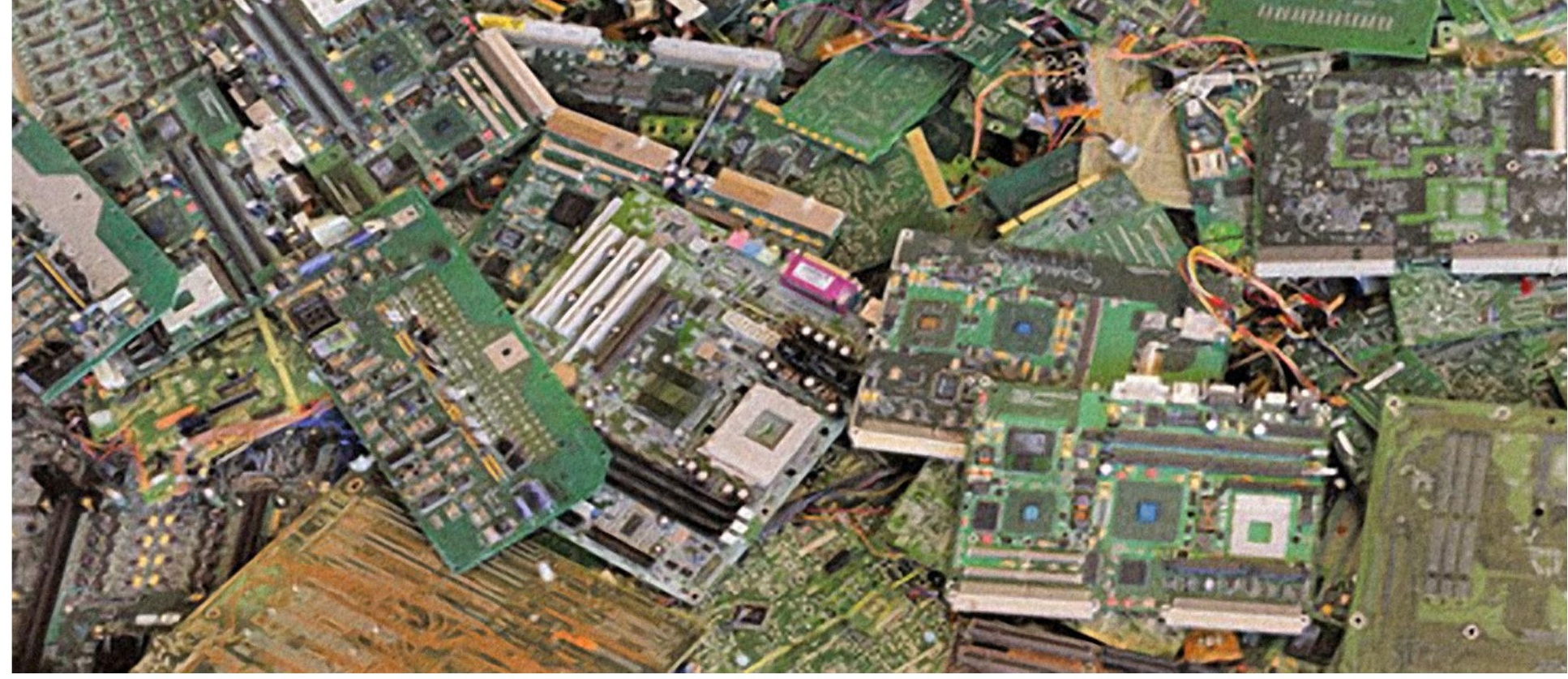




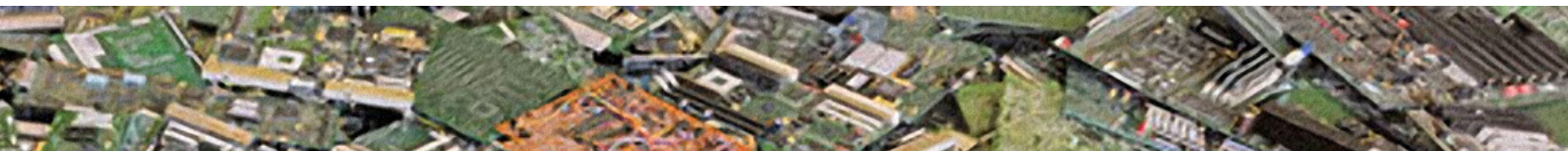

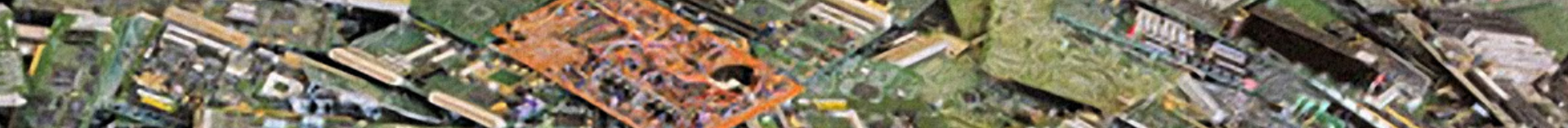

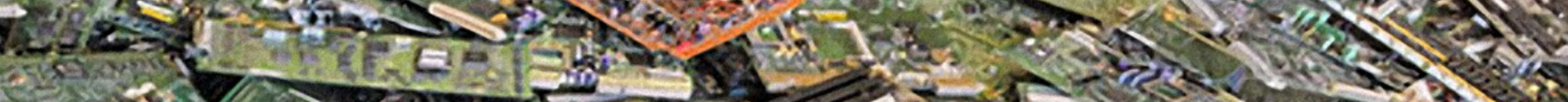

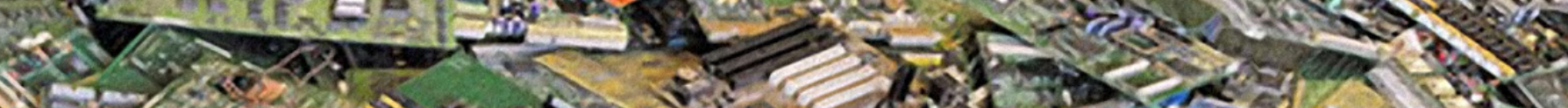

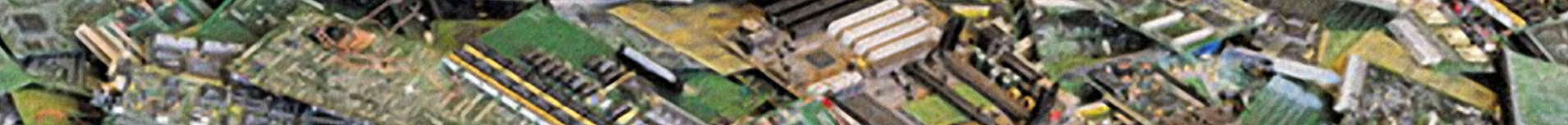
y. 60.121 .

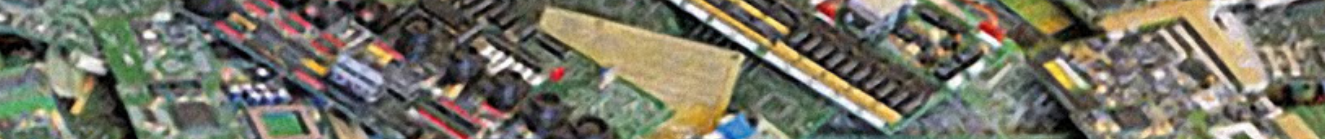
$-12+2=130$. $-5 \cos u=0$ s. the

.
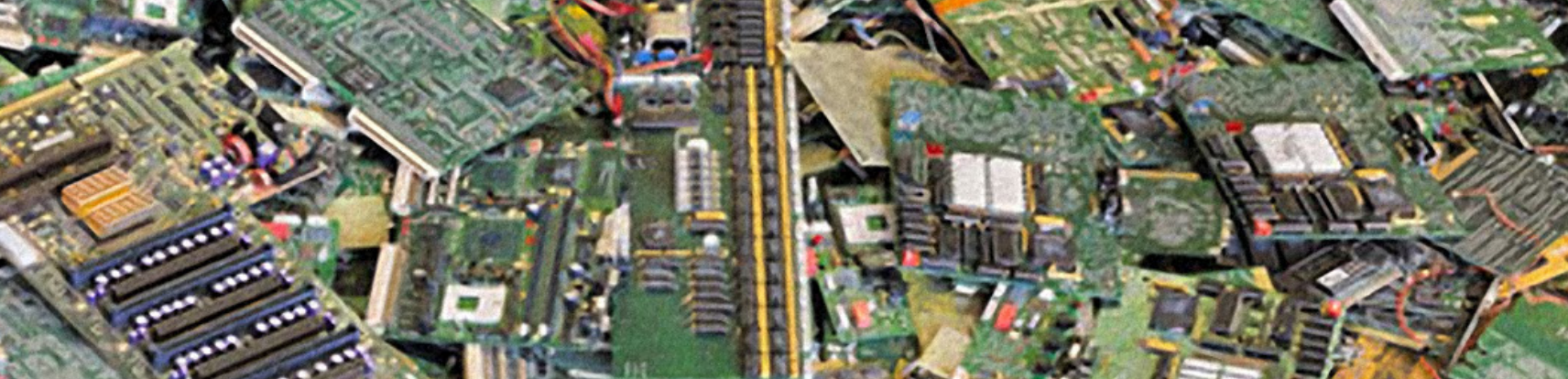

2)

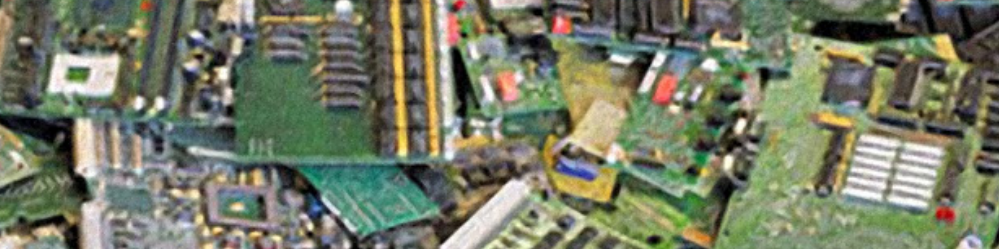

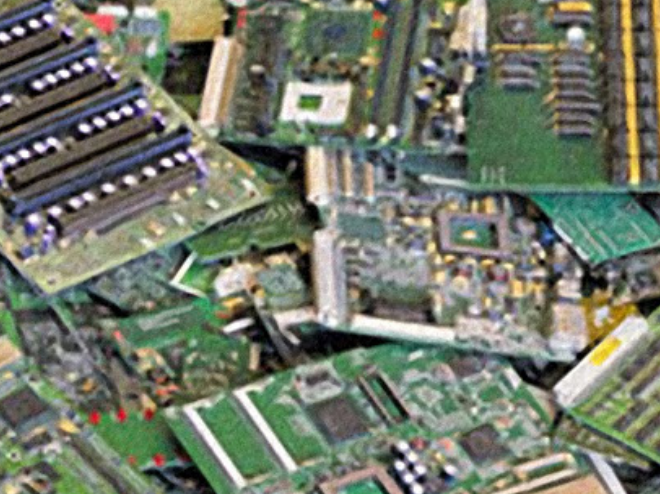

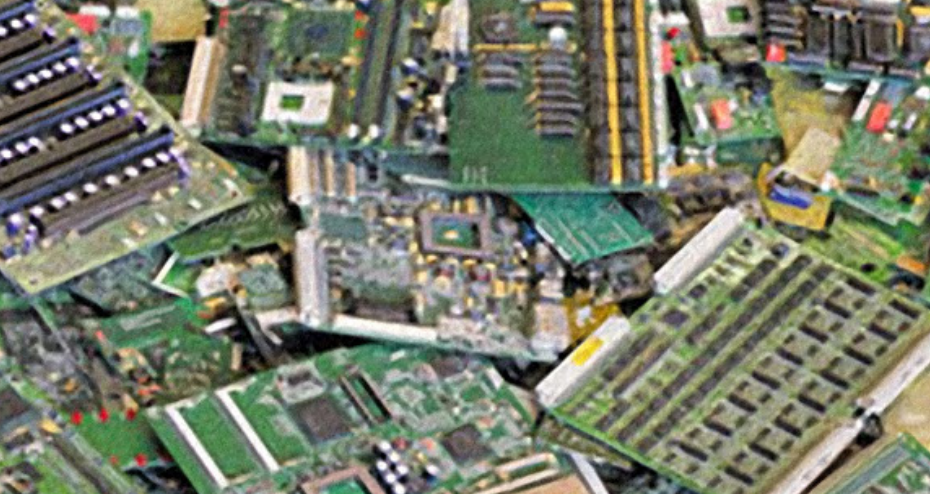 (1) $\rightarrow$ (c)

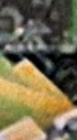
$y+1, y$ 15 $10.5,1+2=5$ (i) - $1-2$. 20

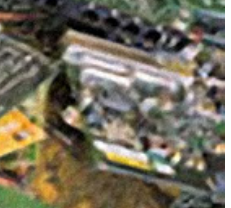
28

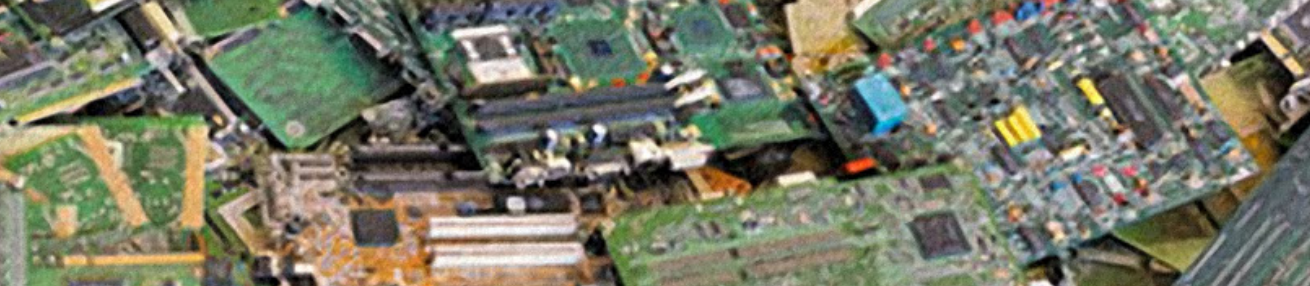

$x+10=$ $=13$

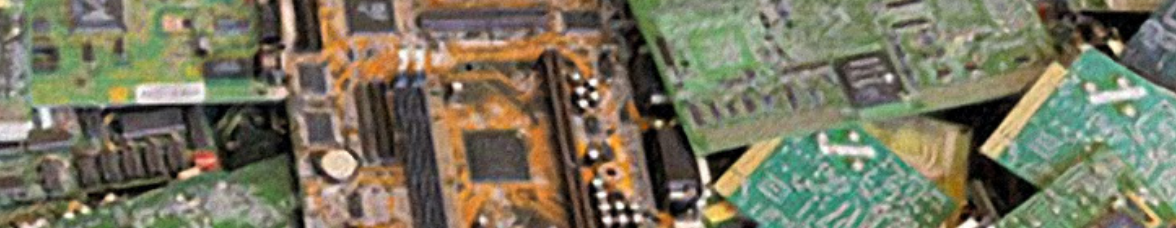

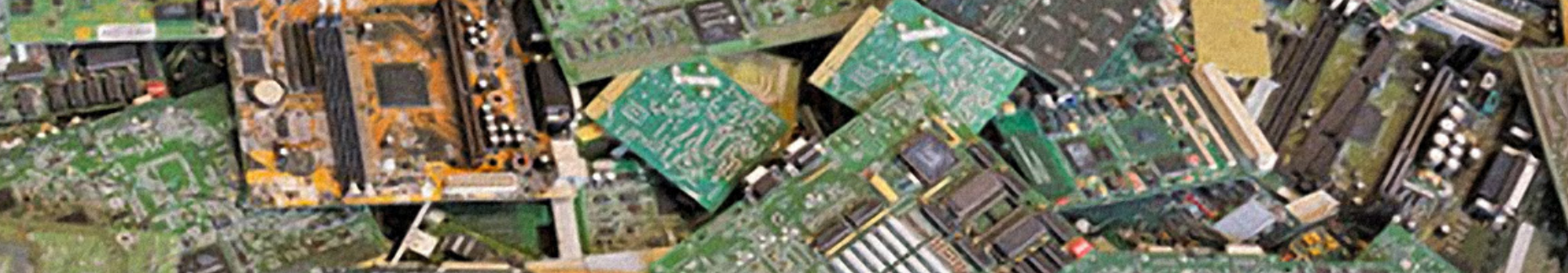

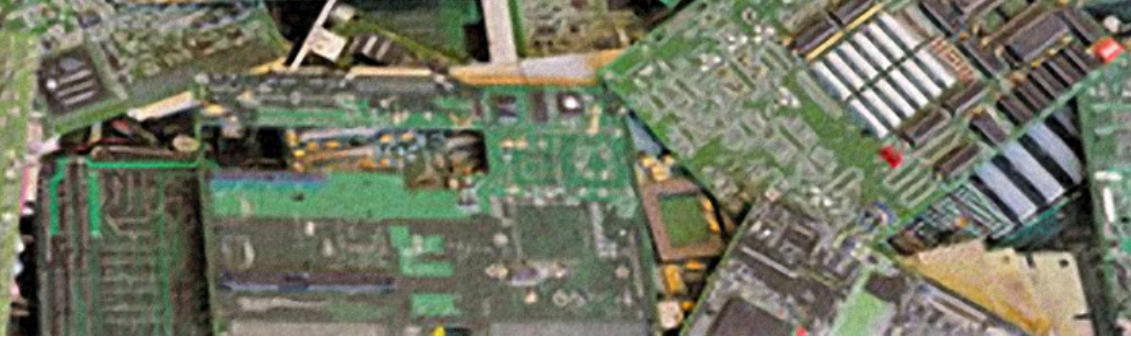




\section{$<$ na página anterior}

Figura 15. Circuit boards \#2, New Orleans 2005.

(Fonte: Ensaio fotográfico de Chris Jordan Intolerable Beauty: Portraits of American Mass Consumption 2003 - 2005 Disponível em http://www.chrisjordan.com/gallery/intolerable/\#circuit\%20boards\%202\%2044x60) 


\section{3}

\section{Materiais e métodos}

\subsection{Caracterização da pesquisa}

Esta pesquisa, de caráter qualitativo exploratório, tem por objetivo identificar as manifestações de obsolescência programada, no que diz respeito a produtos de larga escala, e compreender a relação do design com o fenômeno estudado. Segundo Creswell, "conduzimos pesquisas qualitativas quando um problema ou questão precisa ser explorado" (CRESWELL, 2014, p. 52). Assim, procurou-se fazer uma sondagem da população sobre o tema, por meio eletrônico, e levantar informações que possam servir para futuras pesquisas.

O estudo teve três etapas. A primeira consistiu em uma revisão da bibliografia existente sobre o tema para definir parâmetros para a identificação dos três tipos de obsolescência programada descritos na literatura. Nesta etapa foi possível constatar a carência de estudos relacionados ao tema no Brasil.

Os resultados da primeira etapa da pesquisa serviram de base para a segunda, em que foi aplicado um questionário (com 444 respostas coletadas), divulgado por rede social. A aplicação do questionário foi precedida por uma sondagem inicial, que consistiu na criação e monitoramento de uma página em rede social, que, num segundo momento, também serviu de plataforma para a divulgação do questionário. Com esta 
etapa de coleta de dados, foi possível identificar práticas de consumo descritas na revisão da literatura, assim como os produtos mais identificados com os tipos de obsolescência programada averiguados anteriormente.

A terceira etapa teve como método de coleta de dados cinco entrevistas semiestruturadas com profissionais da indústria brasileira. Os profissionais foram definidos de acordo com as categorias mais citadas no questionário, tais como eletrodomésticos de grande porte e celulares ou setores relevantes para o tema central da pesquisa, como a indústria de carros.

A íntegra do questionário e o roteiro das entrevistas semiestruturadas, utilizadas na pesquisa, encontram-se como anexos desta dissertação.

\subsection{Etapa 1: procedimento para coleta de dados} sobre o histórico do fenômeno e definição dos parâmetros conceituais para a identificação da obsolescência programada atualmente

Conforme exposto no capítulo anterior, a primeira etapa da pesquisa consistiu na revisão da literatura existente e na definição de parâmetros conceituais que tornassem possível a identificação dos tipos de obsolescência programada, um dos objetivos desta pesquisa, expostos no capítulo 1.

Os principais autores abordados foram: Gordon Lippincott (1947), que descreve a profissão de designer no auge da obsolescência programada; Vance Packard (1965), por abordar as práticas de consumo identificadas com o fenômeno estudado, assim que a prática foi adotada nos EUA; Victor Papanek (1971), por ser o primeiro autor a propor ao design a iniciativa de mudança nas práticas relacionadas à obsolescência programada; Giles Slade (2007) por ser um autor contemporâneo que reflete sobre o fenômeno no século XXI, além de traçar um histórico detalhado do tema. Também foram pesquisados artigos científicos e trabalhos acadêmicos que tratassem do tema, bem como pesquisas de mercado ou autores que complementassem o conhecimento sobre o assunto, conforme exposto no capítulo anterior. 


\subsection{Etapa 2: procedimento para coleta de dados sobre práticas de consumo relacionadas com a obsolescência programada, conhecimento do termo e do fenômeno e principais produtos citados pelos participantes da pesquisa}

A segunda etapa da pesquisa teve, num primeiro momento, uma sondagem feita por meio da página do Facebook intitulada "Feitos para Quebrar". ${ }^{45}$ A página teve o intuito de abrir um espaço para que o maior número de pessoas compartilhasse experiências e ideias sobre os hábitos de consumo e o conhecimento sobre a obsolescência programada, de maneira indireta. As publicações diziam respeito a produtos e hábitos de consumo específicos, intercaladas com posts sobre a prática em si. A página serviu como uma sondagem para o questionário, que possui perguntas algumas semelhantes aos posts, porém de maneira mais espontânea e com estímulos diferentes do que $o$ questionário, uma vez que é possível visualizar os demais comentários, estimulando assuntos e produtos. A página foi posta no ar no dia 16 de novembro de 2016 e, até o encerramento da coleta de respostas do questionário, no dia 02 de junho de 2017, foram realizadas 32 publicações.

A etapa do questionário contou com a colaboração da equipe do Centro de Estatística Aplicada (CEA-USP). Após reunião realizada com as professoras Lúcia Pereira Barroso e Viviana Giampaoli e com os alunos Laryssa Del Corso Costa e Diego Ribeiro Marcondes, foi solicitada uma análise da pertinência do método de pesquisa adotado, assim como uma avaliação do questionário elaborado. No relatório, elaborado pelo centro, a aplicação do questionário foi validada por ter como objetivo

[...] realizar uma sondagem da população de interesse, com o intuito não de fazer inferências sobre tal população e obter conclusões válidas para ela como um todo, mas de observar tendências e casos particulares que possam servir como base para estudos futuros sobre características mais específicas da obsolescência programada e suas particularidades na sociedade brasileira. (ANEXO 1, p. 4)

O questionário foi elaborado a partir da revisão bibliográfica, baseando-se nos parâmetros de práticas de consumo listados por Packard (1965) e Slade (2007), e teve um intuito eminentemente descritivo - por essa razão foi composto por perguntas abertas e fechadas. Ele foi submetido à análise dos alunos do CEA presentes na reunião, e todas as sugestões contidas no relatório elaborado por eles foram acatadas no instrumento final de coleta aplicado. As perguntas do questionário foram divididas em quatro grandes blocos, com o intuito de identificar:

${ }^{45} \mathrm{https}: / / \mathrm{www}$. facebook.com/feitosparaquebrar. 
O respondente. Neste bloco os campos relacionados ao nome, idade, profissão e número de pessoas na casa dos respondentes eram abertos e deveriam ser respondidos individualmente; as demais, a respeito de gênero, escolaridade, estado onde mora e renda continham campos de múltipla escolha. ${ }^{46}$

Suas práticas de consumo. Neste bloco de perguntas, os campos eram de múltipla escolha, mas continham espaços opcionais para comentários a respeito dos itens assinalados. Procurou-se respostas a respeito de hábitos de consumo, como: utilização de produtos por muito tempo ou troca frequente; preocupação com a assistência técnica e durabilidade na hora da compra; compra de produtos novos e usados; motivação para a compra (aparência, tecnologia); formas de pagamento; opinião a respeito das frases "o que é novo é bom, e o que é velho é ruim" e "se um produto é barato, pode durar pouco; se é caro, deve durar muito".

Os produtos mais citados. Neste bloco de perguntas, também os campos eram de múltipla escolha, mas continham espaços opcionais para comentários a respeito dos itens assinalados. Indagou-se sobre produtos específicos adquiridos. $\mathrm{O}$ intuito era que produtos variados pudessem ser citados. Por essa razão, este bloco de perguntas continha um texto inicial explicativo ${ }^{47}$ que sugeria os tipos de produtos perguntados, sem limitá-los. Os respondentes assinalavam inicialmente um grupo de produtos mais geral num campo de múltipla escolha, para a seguir especificá-los em um campo aberto. Neste bloco os respondentes também foram indagados a respeito do motivo da compra (quebra, troca, lançamento, tecnologia ultrapassada) e, no caso de o motivo assinalado ter sido o fato de o produto anterior ter quebrado, um detalhamento a respeito do ocorrido era também perguntado: por exemplo, se houve tentativa de conserto e quais foram os problemas ou soluções encontradas nesse caso. Havia também perguntas a respeito da satisfação com o tempo que o produto durou e da troca constante de produtos (e quais foram os produtos), assim como produtos antigos em uso pelos respondentes. ${ }^{48}$

\footnotetext{
${ }^{46}$ As perguntas sobre o respondente basearam-se em dados do IBGE e em pesquisa do Idec para definição dos parâmetros colocados e seguiram as recomendações sugeridas pelo CEA (2017, p. 5), tais como deixar um campo aberto para o preenchimento da idade do respondente, para que as faixas etárias pudessem ser definidas posteriormente.

${ }^{47}$ As perguntas a seguir referem-se aos produtos que, ainda que não rigorosamente considerados bens de consumo duráveis pelo mercado, exigem certo planejamento antes da sua compra e, assim, espera-se que durem. São bons exemplos desses produtos: automóvel ou moto, celular, computador, móveis, DVD player, câmera fotográfica, televisor, micro-ondas, impressora, geladeira, freezer, lavadora ou secadora de roupas, fogão, aparelho de ar condicionado, aparelho de som, cafeteira, torradeira, entre outros de que você pode se lembrar.

${ }^{48} \mathrm{O}$ bloco de perguntas sobre práticas de consumo e os produtos mais citados baseou-se em Packard (1965) e Slade (2007), que falam de práticas de consumo relacionadas com a obsolescência programada.
} 
O conhecimento dos respondentes sobre a obsolescência programada. Neste bloco a primeira pergunta referia-se ao conhecimento do termo, apenas com "sim" e "não" como alternativa de resposta. Em seguida era apresentada uma definição do termo, e o respondente era indagado novamente a respeito da identificação, ou não, desta prática no seu cotidiano, assim como os departamentos de uma empresa que estariam associados a ela, e um incômodo, ou não, com a prática no seu cotidiano. Como nos outros blocos, as respostas tinham campos de múltipla escolha e abertos opcionais para justificativa das opções selecionadas.

O questionário foi aplicado com o intuito de realizar uma sondagem com amostragem não probabilística, pois a intenção da pesquisa foi a de realizar um estudo exploratório preliminar sobre o fenômeno, levantando temas que possam ser explorados em estudos futuros.

Por ser uma sondagem, procurou-se obter o maior número possível de respostas no período determinado para a coleta de dados, não estipulando anteriormente o tamanho da amostra, apenas uma população-alvo. Dessa maneira, procurou-se estudar os consumidores brasileiros com acesso ao Facebook - recorte também sugerido pelo CEA (ANEXO 1, p. 7) - e observar tendências e casos particulares, sem fazer inferências, além de conseguir exemplos de produtos relacionados com a obsolescência. Assim, as conclusões partem dos dados observados e

servem apenas como evidências sobre os hábitos de consumo da população-alvo e inferências para toda a população não devem ser tomadas a partir desses dados. De fato, as conclusões poderão servir de diretrizes para estudos futuros mais detalhados. (ANEXO 1, p. 7)

O questionário foi construído com base na estrutura disponibilizada pelo serviço Google Forms ${ }^{49}$ e disponibilizado por meio de um link divulgado por rede social em 29 de abril de 2017. Os dados obtidos foram consolidados em 2 de junho de 2017, tendo ao todo, 444 participantes.

Por meio deste método foi possível alcançar quatro dos objetivos deste estudo, listados no capítulo 1: identificar as práticas de consumo relacionadas com a obsolescência programada, que permitem inferir sua existência; identificar as manifestações de obsolescência programada no mercado, de acordo com os parâmetros conceituais definidos e as práticas de consumo pesquisadas; identificar os produtos relacionados a cada um dos tipos de obsolescência programada, listando os produtos mais citados; e

${ }^{49}$ Google Forms são formulários eletrônicos disponibilizados pela empresa de tecnologia Google para uso gratuito por usuários cadastrados em sua base. 
averiguar o conhecimento dos consumidores a respeito do fenômeno, dando especial atenção ao fato de identificarem essa prática no seu cotidiano, mais do que o conhecimento do nome que se dá a ela.

\subsection{Etapa 3: procedimento para coleta de dados sobre o papel do design no desenvolvimento de produtos de larga escala e sua consequente relação com a obsolescência programada}

A terceira etapa da pesquisa baseou-se em entrevistas pontuais com profissionais de design escolhidos de acordo com o resultado do questionário. Procurou-se entrevistar designers que trabalhassem em setores relacionados aos produtos mais citados na coleta de dados da etapa 2. Foi escolhido o modelo de entrevista semiestruturada pois, segundo Flick (2004), por partir de um roteiro flexível de perguntas abertas, ela possibilita ao pesquisador escolher a sequência de perguntas conforme as informações que surgem no decorrer da conversa.

Uma das dificuldades encontradas para localizar profissionais e marcar as entrevistas foi a de não existir departamento de design em algumas empresas contatadas. Assim, acabou-se por entrevistar profissionais relacionados com as áreas determinadas, sendo ele designers ou não.

O interesse principal das entrevistas foi o de investigar a atuação efetiva da equipe de design (ou do designer) no desenvolvimento de produtos de larga escala e sua consequentemente relação com a obsolescência programada, objetivos desta pesquisa. Procurou-se também averiguar os fatores que influenciam o desenvolvimento de produtos com o intuito de rebatê-los com as práticas de consumo encontradas nas etapas anteriores da pesquisa: revisão da literatura e sondagem.

Assim como o questionário, a entrevista também foi dividida em cinco blocos de interesse. Após perguntas referentes ao perfil do entrevistado e da empresa, procurou-se obter informações a respeito:

Do departamento de design da empresa. Se há departamento ou não, se o desenvolvimento de produto é feito nacional ou internacionalmente; a relação do departamento com as demais áreas da empresa; os processos dos quais o design participa efetivamente.

Do desenvolvimento de produto. Quais as premissas de projeto e dos lançamentos (economia, sustentabilidade, design); frequência e demanda de lançamentos; investimento em pesquisas. 
Da legislação. De que maneira a legislação, como a Política Nacional de Resíduos Sólidos, interfere no desenho dos produtos; intenção de instituir ou não a logística reversa no ciclo dos produtos; possíveis adequações em produtos importados.

Das práticas sustentáveis da empresa. Preocupação com a assistência técnica; pesquisas com uma "intenção" mais sustentável, tanto no que diz respeito a materiais como a processos ligados à manufatura dos produtos.

Da obsolescência programada. Neste momento da entrevista, a abordagem da obsolescência programada foi mais direta, e procurou-se aprofundar mais as questões que permeiam a prática, bem como sua relação com o design.

\subsection{Procedimento para análise e tratamento dos dados coletados}

Partindo dos objetivos estipulados no início da pesquisa, procurou-se separar os dados coletados nos três grandes temas que a nortearam, de acordo com as três etapas expostas nos itens anteriores deste capítulo:

1) Histórico do fenômeno e definição dos parâmetros conceituais para a identificação da obsolescência programada atualmente.

2) Práticas de consumo relacionadas com a obsolescência programada, conhecimento do termo e do fenômeno e principais produtos citados pelos participantes da pesquisa.

3) O papel do design no desenvolvimento de produtos de larga escala e sua consequente relação com a obsolescência programada.

Inicialmente, a partir da revisão da literatura, estipulou-se os parâmetros conceituais para que fosse possível inferir a existência da obsolescência programada atualmente, assim como identificar os tipos existentes.

Os resultados obtidos no questionário foram consolidados inicialmente em uma tabela com formato compatível ao do programa Microsoft Excel. Os dados foram organizados, em uma linha para cada respondente, composta por diversas colunas referentes às respostas dadas a cada questão ou espaços em branco no caso de alguma pergunta não ter sido respondida. Em seguida foram tabulados, tratados e analisados 
na plataforma $\mathrm{R}$ (versão 3.3.3) por Eduardo Lazzari ${ }^{50}$ e seus resultados apresentados em um relatório (disponível no anexo 2).

Devido ao fato de a amostra ter se revelado muito desigual, foi adotado como tratamento principal dos dados o teste qui-quadrado, pois com ele, segundo Lazzari (ANE$\mathrm{XO}$ 2, p. 1), "testa-se se duas variáveis nominais independentes ou não entre si, de forma que a hipótese nula deste teste é de que as variáveis dependente e independente não estão associadas." ${ }^{\prime 1}$

A partir dos parâmetros conceituais definidos na primeira etapa da pesquisa, os dados e depoimentos colhidos na página em rede social criada para a pesquisa e aqueles coletados com a aplicação do questionário foram analisados e separados de acordo com os três temas listados acima, desmembrando-se em novas categorias conceituais que emergiram no decorrer do tratamento de dados.

\footnotetext{
${ }^{50}$ Eduardo Alves Lazzari é bacharel em relações internacionais (PUC-SP) e em ciências sociais (USP) e mestre e doutorando em ciência política pela USP. Integrou o Grupo de Ensino e Pesquisa em Inovação (Gepi) da Fundação Getúlio Vargas de São Paulo e atualmente é responsável pelo desenvolvimento de análises e estudos quantitativos em diferentes processos de consultoria na empresa Move.

${ }^{51}$ "A estatística é auferida a partir da somatória da diferença entre a frequência observada $(0)$ e esperada (E) em cada célula (j) da tabela de contingência gerada, conforme fórmula a seguir: $\mathrm{x}^{2}=(\mathrm{Oj}-\mathrm{Ej})^{2} \mathrm{Ej}$. De modo que os graus de liberdade, necessários para o teste da hipótese nula são obtidos por meio da multiplicação do número de linhas menos um e o número de colunas menos um.” (LAZZARI, 2017, p. 1)
} 



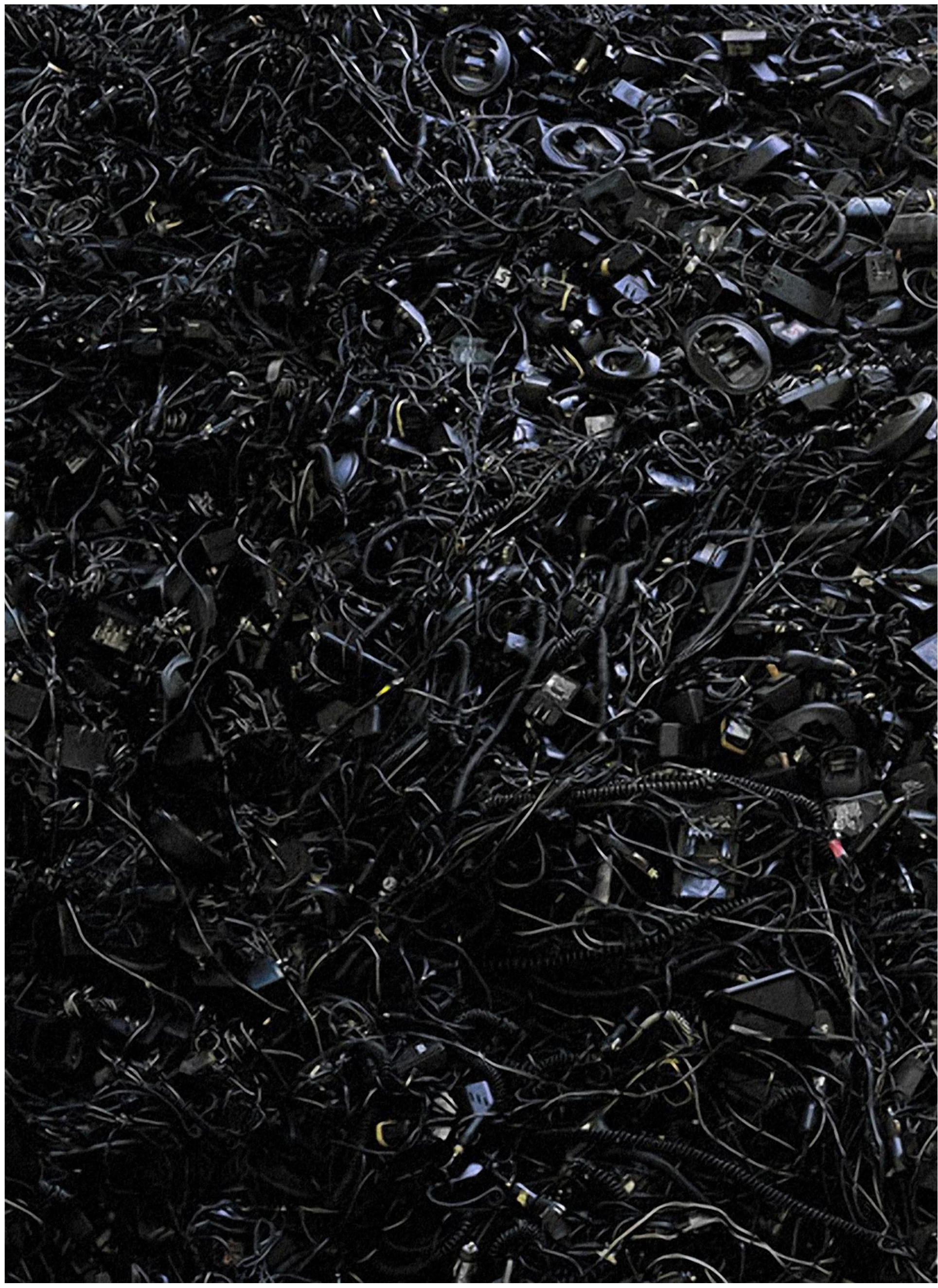




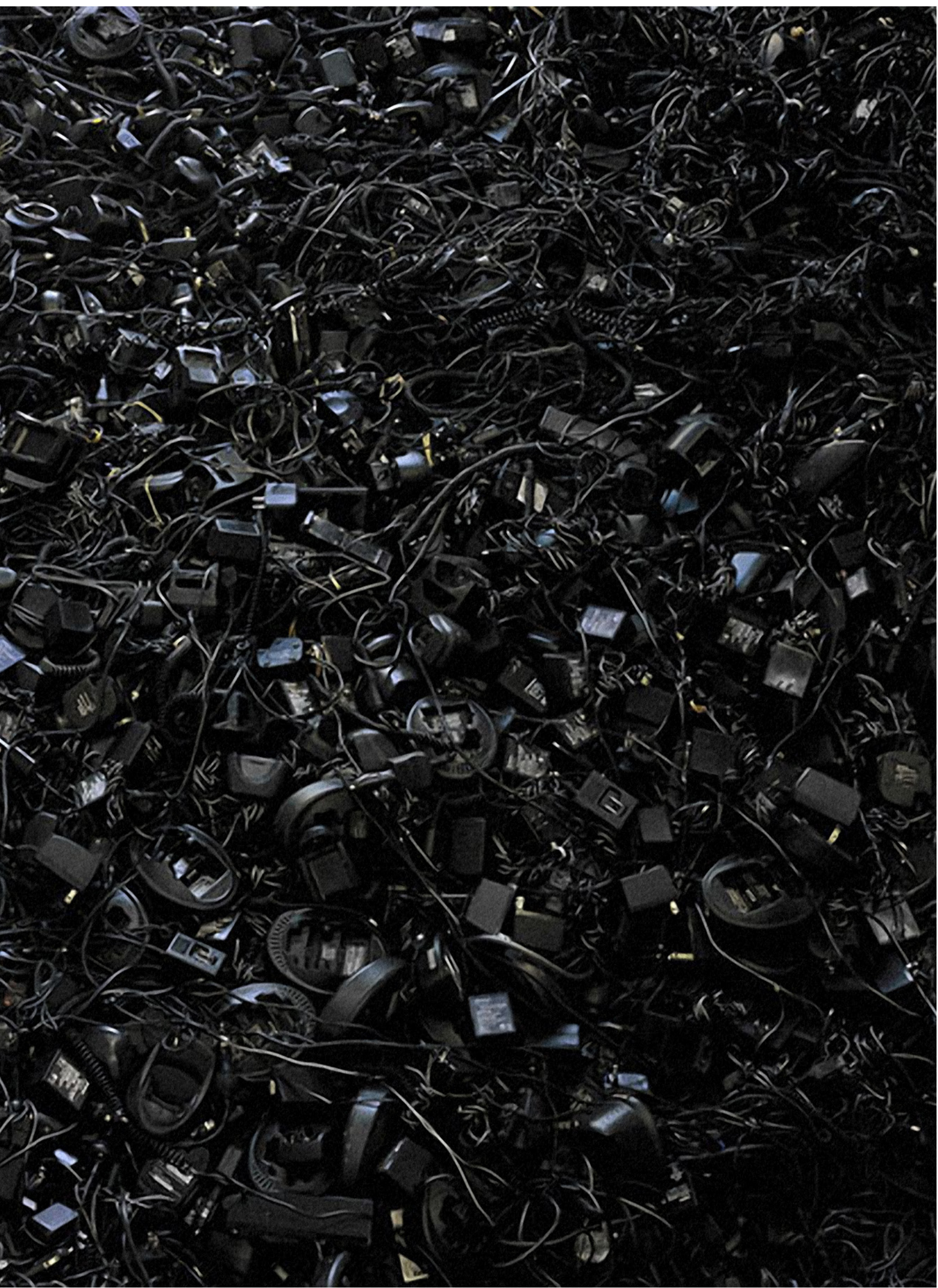




\section{< na página anterior}

Figura 16. Cell phone chargers, Atlanta 2004.

(Fonte: Ensaio fotográfico de Chris Jordan Intolerable Beauty: Portraits of American Mass Consumption 2003 - 2005 Disponível em http://www.chrisjordan.com/gallery/intolerable/\#cellphone\%20chargers\%2044x66.5) 


\section{4 \\ Resultados e discussão}

Conforme explicitado no capítulo 1 desta dissertação, procurou-se aferir a existência da obsolescência programada de maneira indireta, ou seja, por meio da identificação de práticas de consumo descritas no referencial teórico. Isso porque, ainda que hajam artigos científicos, livros, documentários e matérias jornalísticas tratando do fenômeno e, apesar de muitas situações nos remeterem ao fenômeno estudado, não há afirmação por parte da indústria que admita seu emprego na fabricação de seus produtos. Dessa maneira, o estudo da obsolescência programada a partir da percepção e da experiência real dos consumidores possibilita novos caminhos para sua compreensão.

Por meio da aplicação do questionário, foi possível identificar práticas de consumo que se relacionam diretamente com os três tipos de obsolescência programada definidos no Quadro 1 do primeiro capítulo - tecnológica, psicológica e artificial. Também nas entrevistas realizadas, foi possível fazer um cruzamento das práticas de consumo descritas pelos consumidores com práticas adotadas pelas empresas, como veremos a seguir.

Antes da apresentação dos resultados, é imprescindível que se faça uma descrição da amostra obtida com o questionário, pois, como dito no capítulo anterior, por ser uma sondagem com coleta de dados acidental, ela acabou por ter características muito desiguais, de modo que alguns recortes para a explicação de percepções de interesse foram dificultados. 
A população estudada é majoritariamente feminina (70\% dos respondentes são mulheres), altamente escolarizada, com $87 \%$ dos respondentes sendo pós-graduados e com alto poder aquisitivo, pois $43 \%$ afirmaram ter renda familiar mensal de mais de sete salários mínimos. Por essa razão, cruzamentos entre as variáveis "gênero", "renda" ou "escolaridade não devem ser tomados como generalizações para a sociedade como um todo, mas restritos a esse grupo.

Participaram da pesquisa 444 pessoas, com idade média de 40 anos. Grande parte dos respondentes mora no estado de São Paulo (78\%) e em sua maioria moram na capital. As profissões listadas são bastante variadas, valendo destaque para respondentes que afirmam ser professores (53), designers (38), arquitetos (34) e jornalistas (30). ${ }^{52}$ Vale comentar que havia uma expectativa de que a profissão de designer fosse relevante para as atitudes pesquisadas com o questionário, porém, nos testes de associação realizados, isso não se mostrou relevante.

Outra característica importante da população estudada é o alto conhecimento do termo "obsolescência programada": 72,9\% dos respondentes do questionário afirmaram conhecê-lo. Ainda que a caracterização da amostra provavelmente tenha sofrido influência do meio em que foi divulgado o questionário, suas características vão de encontro a uma tendência pesquisada pelo Instituto $\mathrm{Akatu}^{53}$, que revela o crescimento no Brasil de uma assimilação de um consumo consciente, independente de diferenciação socioeconômica ou geográfica, conforme uma de suas conclusões: "confirma-se que o consumo consciente não se caracteriza como peculiaridade de nenhum segmento específico, a despeito da ligeira tendência para maior adesão entre universitários, integrantes das classes A e B, e pessoas acima de 45 anos" (INSTITUTO AKATU, 2013, p. 10).

Portanto, a sondagem realizada e os resultados aqui apresentados não têm o intuito de fazer inferências ou obter conclusões válidas para a população estudada como um todo nem tampouco sobre a população brasileira, não tendo validade estatística para inferir tendências de comportamento. Por ser uma sondagem, procurou-se observar aspectos sobre características específicas da obsolescência programada que possam servir a estudos futuros, conforme explicitado no capítulo 3.

\footnotetext{
52 Para maiores detalhes, ver anexo 2.

53 A pesquisa é um registro de conclusões e observações feitas pelo Instituto Akatu com base nos dados coletados em pesquisa quantitativa realizada no final de 2012. Tais informações foram analisadas no início de 2013 pela equipe do instituto, em conjunto com seus conselheiros, consultores e especialistas convidados. Foram entrevistados oitocentos brasileiros e brasileiras das classes A, B, C e D, com idade acima de 16 anos, moradores em áreas urbanas de doze capitais ou regiões metropolitanas de todo o país. Foi realizado o controle de cotas e tratamento estatístico necessário para a adequada representação e análise da população nacional. Os trechos reproduzidos aqui são do primeiro bloco da pesquisa, que teve como foco o comportamento do consumidor brasileiro em relação ao consumo consciente (INSTITUTO AKATU, 2013).
} 
Vale lembrar também que há diferença entre declaração e atitude, sendo esta uma limitação da pesquisa, pois serão expostas as declarações dos participantes, não havendo como confrontá-las com seus comportamentos reais ou suas atitudes individuais e sociais. Esta distinção é importante, pois, segundo Rodrigues (2005), não há correspondência perfeita entre atitude e comportamento. Já de acordo com Dantas (2012) ${ }^{54}$, as atitudes sociais se formam de diferentes maneiras: reforço ou recompensa, características da personalidade, imitação ou modelagem, identificação com determinado grupo ou classe social e análise racional. Elas também podem ser modificadas por diversos fatores, como pela influência social de outras pessoas.

Como veremos detalhadamente a seguir, os produtos mais assinalados no questionário foram, em ordem decrescente: celular, eletrodomésticos de grande porte e eletrodomésticos de pequeno porte. Dessa maneira, procurou-se entrevistar designers que trabalhem em empresas produtoras dos produtos citados ou que já os tenham projetado.

Foram realizadas duas entrevistas com os designers Newton Gama ${ }^{55}$ e Marcos Batista, ${ }^{56}$ ambos com experiência dentro de grandes empresas - Whirpool e Continental, respectivamente - e também como consultores independentes no desenvolvimento de eletrodomésticos de grande e pequeno porte; e três entrevistas com profissionais das empresas relacionadas à indústria de equipamentos para cozinha (Falmec), ${ }^{57}$ de telefones celulares (Samsung) ${ }^{58} \mathrm{e}$ à indústria de automóveis (General Motors), ${ }^{59}$ que, apesar de não ter sido muito citado no questionário, é o primeiro grande caso de obsolescência programada, conforme visto no capítulo 2.

Os resultados encontrados nos diferentes tipos de coleta de dados serão apresentados em quatro blocos: 1) práticas de consumo identificadas; 2) os principais produtos citados e os tipos de obsolescência identificados; 3 ) o departamento de design dentro das empresas entrevistadas; e 4) a percepção do fenômeno.

\footnotetext{
${ }^{54}$ Denise Dantas, disciplina Design centrado no usuário: conceitos, métodos e aplicação (material de aula, 2012).

55 Newton Gama Júnior formou-se na primeira turma de desenho industrial da Universidade Federal do Paraná e trabalhou 27 anos na empresa Whirlpool, dona da das marcas Consul e Brastemp. Segundo Ethel Leon, "Newton Gama é reconhecido como alguém que mudou a cultura de design empresarial no Brasil, especialmente na relação estabelecida entre matriz e filiais dos grandes grupos multinacionais" (LEON, 2005, p. 159). Começou a trabalhar na Consul no ano de 1978, tornando-se diretor de design da Multibrás (braço da Whirpool para a América Latina, detentora das marcas Brastemp e Consul) entre 1994 e 2005, quando deixou a empresa, atuando como consultor independente para diversas marcas, entre elas a Esmaltec, fabricante de eletrodomésticos para a cozinha, voltada para classes C e D.

${ }^{56}$ Marcos Batista é especialista em design estratégico e trabalhou na empresa Continental entre 1991 e 2008. Foi gerente de design das marcas Bosch, GE, Continental e Siemens a partir de 2002. Após sua saída da Continental em 2008, tornou-se consultor independente, palestrante sobre design estratégico, professor e coordenador de cursos de pós-graduação e graduação, em instituições como o Istituto Europeo di Design (IED) e Faculdade de Negócios da Fundação Getulio Vargas (FAN-FGV).

${ }^{57}$ Foi entrevistado o gerente de marketing e designer gráfico da empresa Falmec, identificado como "entrevistado 1".

${ }^{58}$ Foi entrevistado um dos gerentes de operações da Samsung, que pediu para não ter seu nome divulgado, identificado como "entrevistado $2 "$

${ }^{59}$ Foi entrevistado o engenheiro de produto da GM, que pediu para não ter seu nome divulgado, identificado como "entrevistado 3 ".
} 


\subsection{Práticas de consumo identificadas na pesquisa}

Sobre questões mais gerais de práticas de consumo, entre os 444 participantes, 432 afirmaram usar seus produtos pelo maior tempo possível ao invés de "trocá-los sempre que uma nova versão é colocada no mercado" e 369 afirmaram sempre tentar consertá-los ao invés de trocá-los quando apresentam defeitos.

Sobre as formas de pagamento, a maioria das pessoas adquire seus produtos por meio de um pequeno número de parcelas, e apenas 149 dos respondentes afirma pagar suas compras à vista, conforme ilustra o Gráfico 1.

\section{Gráfico 1}

Opções de Pagamento

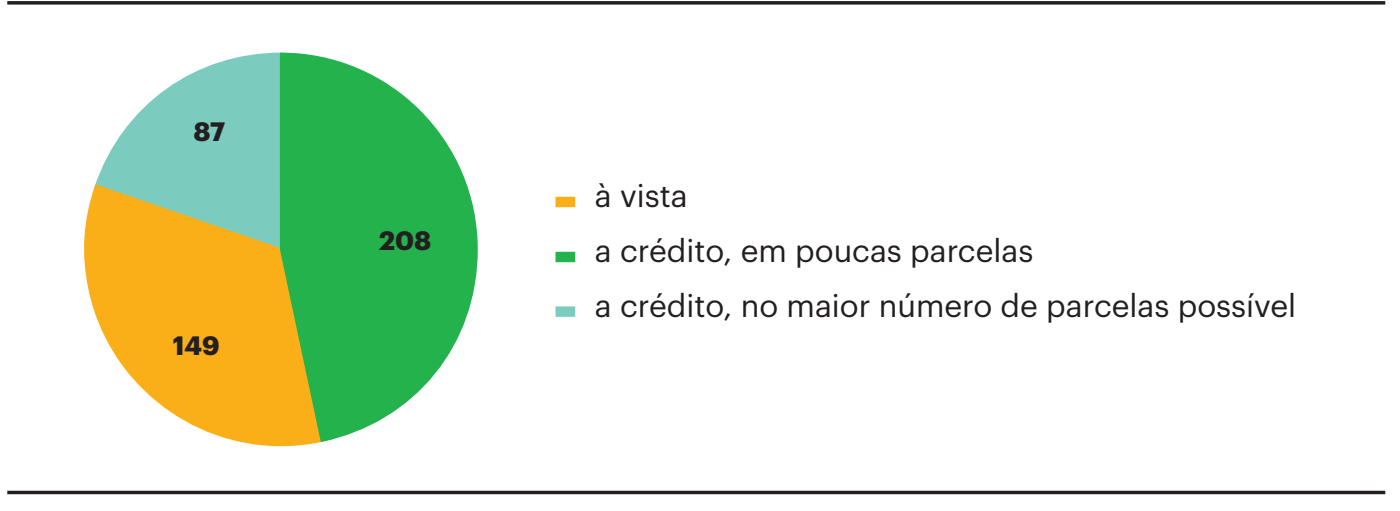

Fonte: elaborado por Eduardo Lazzari, a partir de dados do questionário, 2017.

Nos testes de associação entre as variáveis de interesse da pesquisa, pode ser observado o impacto entre a forma de pagamento e a relevância da assistência técnica, sendo que ela é proporcionalmente menos importante entre aqueles que pagam seus produtos à vista.

Também pode ser identificada uma associação entre a forma de pagamento e o conhecimento do tema da pesquisa: proporcionalmente o conhecimento do termo de obsolescência programada é maior entre aqueles que afirmaram pagar suas compras à vista.

Não foram encontrados, porém, dados relevantes que apontem a forma de pagamento como uma influência sobre a compra de produtos usados, a concordância com a frase "se é caro, deve durar muito" ou a satisfação com o tempo que o produto durou, por exemplo. Também não existe associação entre a forma de pagamento e a necessidade pela qual o bem foi adquirido.

De acordo com o documentário The man who made us spend (2014), o crédito tem um efeito mágico nas compras no início da década de 1980, pois "bastava tirar um pedaço de plástico" da sua carteira para gastar um dinheiro que ainda não havia sido 
ganho. No mesmo sentido, Packard (1965) classifica o crédito como uma das estratégias para o desperdício relacionadas com a obsolescência programada, pois permite que o consumidor realize a compra, diversas vezes de maneira impulsiva, ainda que esteja sem dinheiro.

A partir das respostas obtidas podemos considerar que o crédito, definido por Packard (1965) como estratégia de desperdício, se consolidou como uma prática de consumo.

\subsubsection{Associação entre o conceitos: novo e bom; velho e ruim; caro e durável; barato e frágil}

A associação entre material, valor e durabilidade também fez parte do questionário por meio das frases "o que é novo é bom, e o que é antigo é ruim" e "se um produto é barato, pode durar pouco, se é caro, deve durar muito". Os participantes foram perguntados sobre o grau de concordância ou discordância das frases e, em seguida, tinham a opção de comentar sua escolha em um campo aberto. As respostas a respeito da concordância ou não com as frases foram bastante heterogêneas, e há uma discordância maior para a frase "o que é novo é bom, e o que é antigo é ruim" do que para "se um produto é barato, pode durar pouco, se é caro, deve durar muito", conforme expõe o Gráfico 2.

\section{Gráfico 2}

Concordância com as frases

"O que é novo é bom, e o que é antigo é ruim"

Concorda totalmente

Concorda parcialmente

Não concorda nem discorda

Discorda parcialmente

Discorda totalmente

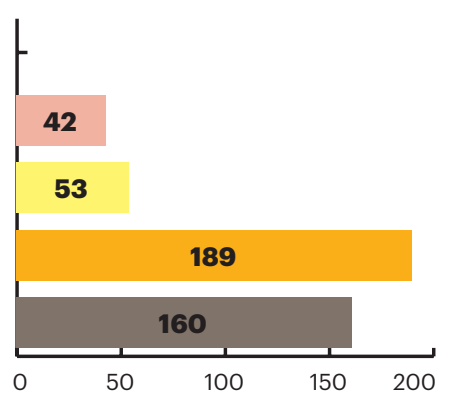

"Se um produto é barato pode durar pouco, se é caro deve durar muito"

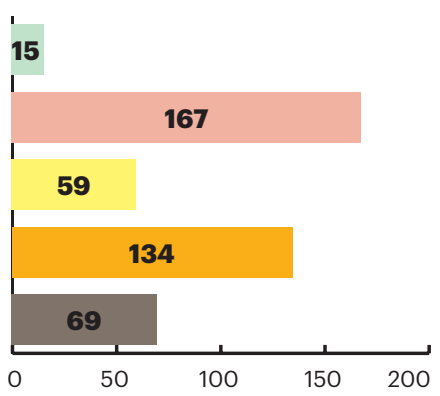

Fonte: elaborado por Eduardo Lazzari, a partir de dados do questionário, 2017. 
Nenhum dos participantes da pesquisa concordou totalmente com a frase "o que é novo é bom, e o que é antigo é ruim", porém vale destacar a seguir alguns dos depoimentos dos respondentes que assinalaram as demais alternativas:

- Entre os 42 participantes que concordaram parcialmente com a frase, onze comentaram sua escolha, das quais destaca-se: um respondente que justifica sua escolha por afirmar que a durabilidade de um micro-ondas antigo é maior do que a de um novo; dois respondentes que fazem uma comparação entre produtos novos e antigos, afirmando que hoje design e eficiência energética são melhores, porém os materiais utilizados atualmente para a fabricação dos produtos é pior; três respondentes acreditam que produtos antigos podem ser melhores ou tão bons como produtos novos; um dos respondentes cita a questão de hoje serem utilizados muitos sistemas eletrônicos, mais difíceis de serem consertados do que os sistemas mecânicos de antigamente; mas, por outro lado, um outro respondente afirma que produtos novos dão menos manutenção.

- Entre os 53 participantes que não concordam nem discordam da frase, quatro (entre os dez que comentaram suas respostas) afirmaram que a frase depende do produto; na opinião de um desses quatro respondentes micro-ondas antigos duravam mais do que os atuais. Vale destaque também a diferenciação que um dos respondentes faz: "Antigo é diferente de velho. Antigo pode ser raridade e me atender bem. Máquinas fotográficas antigas (manuais) são ótimas".

- Foram 189 participantes que discordam parcialmente da afirmação, dos quais sessenta justificaram sua resposta. Entre os depoimentos, dezenove discordam da frase por ela depender do produto em questão e dezoito fazem uma comparação entre durabilidade de materiais e avanço tecnológico, conforme dois dos comentários: "Produtos antigos tinham maior durabilidade, novos oferecem mais tecnologias. A função principal de uma geladeira é refrigerar, e as antigas cumpriram tal função por décadas. As novas oferecem outros atrativos, mas têm pouca durabilidade."; "Acho mais verdadeiro para tecnologias de ponta utilizadas na medicina, por exemplo. Mas para produtos de consumo em geral, só tendo uma visão muito edulcorada do capitalismo. Meu carro todo eletrônico é mais confortável, mas quando meu Fusca quebrava qualquer um consertava em qualquer lugar.” Dentro dos avanços dos produtos, foi citado por dois participantes a questão da redução do gasto energético dos equipamentos eletroeletrônicos. Entre os respondentes existem também aqueles que acreditam que produtos antigos duravam mais do que os novos - oito pessoas fizeram esta declaração. A associação entre a frase e 0 fenômeno estudado apareceu no depoimento de doze participantes. 
- Entre os 160 participantes que discordam totalmente da frase, treze (entre os 45 que comentaram suas respostas) acreditam que os produtos tinham maior qualidade e eram mais duráveis no passado e quatro acreditam que qualidade é algo "questionável" hoje em dia ou que os produtos atualmente são piores, como o exemplo do depoimento a seguir: "O que experimentei é comprar produtos novos com menor qualidade, mas o preço do conserto é inviável. Imagino que propositalmente". Nota-se também neste depoimento certo conhecimento do fenômeno estudado, e, da mesma maneira, existem sete depoimentos que fazem menção direta ou indiretamente a obsolescência programada como se lê a seguir: "Antigamente os produtos eram feitos pra durar o máximo. Hoje são feitos pra durar até a próxima atualização.” São catorze os respondentes, que assim como nas outras opções justificam sua discordância por a frase ser válida ou não dependendo do produto a que nos referimos. Um dos respondentes também faz uma comparação entre qualidade dos materiais e novas tecnologias como se lê no depoimento "os equipamentos novos, apesar de trazerem novas tecnologias, são bem menos duráveis, construídos com material bem mais frágil em geral". Vale destacar também um comentário que faz distinção entre qualidade e durabilidade: "antigamente, havia uma tendência de certos produtos durarem mais; não é universal: móveis da década de 70 e 80 eram de péssima qualidade".

De maneira geral observa-se nos comentários uma tendência a afirmar que antigamente os produtos duravam mais, e essa tendência muitas vezes aparece justificada pelos materiais usados atualmente serem mais frágeis do que os mais antigos. Nesse sentido não há uma concordância absoluta com a frase no sentido de associar-se novo a bom ou ruim - o mesmo valendo para velho - mas há, contudo, uma associação entre novo-frágil e antigo-durável. Há também uma associação entre durabilidade e materiais, sendo comentado diversas vezes que os materiais de hoje são mais frágeis que os antigos. No mesmo sentido, pode-se observar também uma comparação entre material e tecnologia que não valida a afirmação da frase. A tecnologia é descrita como algo positivo em alguns casos, como quando se fala de economia de energia ou ampliação de funções de um produto, e como algo negativo em outros, como em relação à dificuldade de conserto por exemplo.

Por meio da segunda frase, "se um produto é barato, pode durar pouco, se é caro, deve durar muito", e das associações "barato-pouco durável” e "caro-durável" relacionadas a ela, procurou-se averiguar se a ideia de descartável sugerida como uma das estratégias para o desperdício segue válida. Segundo Packard 
(1965), era preciso mudar a noção tradicional de que a durabilidade é o principal aspecto de mérito dos produtos, que faz valer o que se paga por ele. Na relação entre o conceito de "caro" atrelado à "bom ou resistente" e "barato" atrelado à "ruim ou frágil”, soma-se também a ideia dos produtos tornarem-se mais descartáveis, uma vez que durabilidade passa a não ser o principal aspecto de mérito dos produtos. Os resultados apontam para uma concordância com a frase mais do que uma discordância.

- Entre os quinze participantes que afirmaram concordar totalmente com a frase, apenas três justificaram sua escolha, demostrando que ela é uma expectativa que nem sempre se concretiza, como se lê a seguir: "Se eu sei que estou comprando uma versão barata de algum produto, aceito que ele possa ter menor durabilidade. No entanto, ao comprar o produto caro, ele DEVE ser durável" (grifo do respondente).

- Entre os 167 participantes que concordaram parcialmente com a frase, 41 comentaram suas respostas, dos quais nove afirmam ser esta sua expectativa no momento da compra. A relação entre o preço e a durabilidade dependem do produto a que nos referimos, afirmaram quinze dos respondentes. Outros dois citaram a grande presença de produtos chineses no mercado, comentando a sua baixa qualidade de materiais e seus custos reduzidos de produção. Nove participantes disseram que o preço não está necessariamente atrelado à durabilidade e cinco deles afirmam que o preço mais alto pode estar relacionado com o valor agregado de uma marca, por exemplo. Por outro lado, um dos participantes afirma que "infelizmente, muitos dos bens duráveis estão relacionados a qualidade dos componentes. $\mathrm{E}$ os produtos mais baratos tendem a durar menos (pela qualidade dos componentes)". Por fim, há o comentário "tem coisas que a gente compra para durar pouco mesmo".

- Foram 59 os participantes que afirmaram não concordam nem discordam da frase, dos quais dezoito comentaram suas respostas. Entre eles, seis justificam sua resposta por sua veracidade depender do produto em questão, como se lê em um dos depoimentos: "um computador é caro e deve durar muito, uma torradeira mais barata pode durar menos". Três confrontam tecnologia e qualidade dos materiais, enquanto outros três afirma ser esta sua expectativa: "Não acho que deve durar pouco só por ser barato, mas tenho a expectativa que produtos mais caros tenham a durabilidade maior, tenham mais qualidade".

- Entre os 134 participantes que discordam parcialmente da frase, 34 comentaram suas respostas, dos quais dez acreditam que a veracidade da frase depende do pro- 
duto em questão e três afirmam que isso não é "necessariamente" verdade. Alguns participantes também questionam a relação entre qualidade e preço, afirmando que o preço pode estar atrelado não à qualidade, mas ao status do produto, marca ou tecnologia, como se lê a seguir: "costumo comprar produtos em outlets, o que significa que já foram caros e hoje estão baratos — sem alterar a qualidade deles". Um dos participantes atrela a frase ao fenômeno estudado, afirmando que mesmo produtos caros duram pouco hoje. Outro afirma que "em alguns casos, é 'aceitável' (mesmo que não ideal) durar pouco, pelo valor relativamente barato para o que é". Também um dos participantes afirma que "como a gente cuida das coisas tem influência na durabilidade".

- Entre os 69 participantes que discordam totalmente da frase, apenas dezoito comentaram suas respostas: oito não atrelam preço a durabilidade, mas ao valor da marca, por exemplo; quatro dizem depender do produto e dois associam a frase com o fenômeno estudado.

Ainda que não tenha sido um tema proposto especificamente na sondagem do Facebook esses conceitos também apareceram, de maneira espontânea, , como mostra o depoimento a seguir:

\footnotetext{
Meu marido vive com essa teoria de que é melhor pagar caro para que dure mais. Eu sou da que vai quebrar de qualquer jeito então melhor pagar barato e se durar, que prazer! Tenho uma panela que comprei em um mercado popular em Lima há 12 anos que está super inteira. Todo dia que a uso fico feliz. As coisas que duram e foram baratas me deixam feliz!
}

De maneira geral entre as respostas, pode-se identificar uma expectativa de que a afirmação da frase ocorra. Entende-se que isso não é aceitável para alguns participantes, porém outros mostram-se convencidos de que isso é uma realidade. É possível notar também associação entre durabilidade e materiais e entre materiais e custos, sendo relatadas experiências com produtos mais baratos que se mostraram mais frágeis, ocorrendo o mesmo também com produtos mais caros. Há um questionamento sobre os fatores que influenciam os custos, podendo ele estar atrelado a uma nova tecnologia, marca ou acessórios no produto.

O depoimento da internauta reproduzido acima mostra também aceitações diferentes da obsolescência programada: a mulher já a assumiu como um fato inquestionável, enquanto o marido procura acreditar que os produtos caros vão durar mais, o que de certa maneira demonstra mais resistência à ideia de que a obsolescência é um fenômeno difundido e cristalizado na sociedade atual. 


\subsubsection{Durabilidade}

Para 339 dos respondentes da pesquisa, durabilidade mostrou-se algo importante na decisão de compra. Ao serem perguntados sobre sua satisfação, de maneira geral, em relação ao tempo que seus produtos duraram levando em conta o valor pago, 211 dos respondentes afirmaram estar satisfeitos. Por outro lado, ao serem perguntados especificamente sobre a última compra realizada ou a última que considerasse importante, 270 dos respondentes afirmaram que gostariam que o produto que o antecedeu tivesse durado mais.

De acordo com as respostas do questionário, a média de duração dos bens que foram trocados foi de 31 meses, enquanto a expectativa mínima esperada para eles teria sido de sessenta meses. Essa diferença indica uma alta expectativa de durabilidade dos produtos em relação ao que de fato duraram.

Os dados levantados nesta pesquisa coincidem com os dados levantados na pesquisa do Idec e do Market Analysis (2013, p. 24), que identificou uma maior preocupação com a durabilidade dos produtos entre a indivíduos com menor poder aquisitivo. Averiguou-se também naquela pesquisa uma diferença de dois a três anos entre o tempo que os consumidores esperam que os aparelhos durem e o que de fato duram. Uma das conclusões da pesquisa é a de que

Ainda que se mostrem satisfeitos com seus equipamentos, a existência de uma brecha entre a expectativa de durabilidade dos equipamentos e a durabilidade de fato vivenciada pelos consumidores indica uma insatisfação latente dos brasileiros com o tempo de vida útil dos eletrônicos. (IDEC; MARKET ANALYSIS, 2013, p. 60)

Na página do Facebook Feitos para quebrar, o tema da durabilidade também surgiu em alguns comentários, ainda que não tenha sido proposto como um tema específico. As frases encontradas mostram uma expectativa de durabilidade maior do que a de fato vivenciada pelos participantes como a frase de um respondente que diz que "queria tanto ficar com o meu carro até ele virar velhinho".

Nas entrevistas realizadas, ao serem perguntados sobre a durabilidade dos produtos, todos os profissionais afirmaram que isso é uma das grandes preocupações das empresas em que trabalham ou trabalharam. Newton Gama afirma que as empresas querem que dure, pois "a empresa não quer ficar com a fama de que é um produto descartável. Nesse nosso ramo [de eletrodomésticos), não". Para o entrevistado isso pode até se aplicar a celulares, pois na opinião dele

você não fica cinco anos com um celular, não tem como, ele fica antigo, tem monte de programas que não rodam, tem um monte de coisas que não funcionam, então você tem que trocar. Então 
não adianta você fazer um celular robusto, com materiais que vão durar trinta anos, nem pensar. (Newton Gama)

No mesmo sentido, o entrevistado da empresa Falmec afirma que os produtos têm que durar no mínimo dez anos.

Por outro lado, o assunto da durabilidade levou ao tema da escolha dos materiais em algumas entrevistas. Entre os entrevistados, a durabilidade está ligada a materiais, e, de maneira geral, todos afirmaram que a grande mudança que ocorreu nos últimos oitenta anos foi que se passou a ter uma opção maior de materiais, mais baratos, mas também mais frágeis. Isso afeta diretamente a durabilidade dos materiais, conforme o relato do entrevistado da GM:

Se você pegar o interior do carro, por exemplo, antigamente você tinha muito aço no interior do carro, você tinha muito material que durava muito mais e hoje, até por questão de segurança, você não usa mais. Então você não pode ter um painel de instrumentos de aço, porque se você tiver uma batida e o cara bater ali, ele morre na hora. Aí você tem o plástico que deforma e você usa o mínimo de aço possível, mas a contrapartida é que o material se degrada, a durabilidade é menor. Se você pega um carro moderno com dez anos ele parece muito mais acabado do que um carro dos anos 30, com setenta anos. Se o carro estiver bem conservado e se você pegar na mesma proporção, com cinco, dez anos, um carro da década de 40 não estava tão acabado quanto um carro de hoje. (Entrevistado 3)

Algumas empresas para terem preços mais competitivos sem atrelar sua marca a produtos de menor durabilidade optam por terem duas marcas, uma que atenda um mercado de poder aquisitivo mais elevado com produtos mais caros e duráveis e outra com preços mais competitivos e materiais mais baratos para camadas com poder aquisitivo mais baixo. A Falmec é um exemplo disso e produz eletrodomésticos para cocção por meio de duas marcas: a Falmec e a Arix. Segundo relato do entrevistado "são produtos muito básicos, têm a funcionalidade ótima, mas não tem um apelo de design tão forte quanto à Falmec, mas é um produto que entrou pra brigar com os concorrentes, por exemplo, que vêm da China" (Entrevistado 1).

Na Samsung, a divisão não é feita por marcas, mas por categoria de produtos. Atualmente eles oferecem entre oito e doze modelos de celular, separados em três grandes famílias de produtos: $\mathrm{S}$ é a mais sofisticada e utiliza materiais mais nobres; A é a intermediária; J é a mais simples e geralmente seu material externo e a traseira do celular são em plástico. Outra coisa que varia entre as categorias são os programas disponíveis como itens de série, ou seja, eles já vêm instalados quando você compra um celular. 
Gama relata da mesma forma sua experiência na Esmaltec, empresa líder no mercado de fogões. ${ }^{60}$ Segundo ele "são fogões mais simples, mas eles são bons e não são feitos para durar dois anos. Eles duram doze, quinze, se a pessoa for cuidadosa ele vai longe".

\begin{abstract}
Ah, ele é mais frágil, mas aí que tá. Você pergunta assim "esse produto é feito frágil pra durar menos?” Não, ele é feito frágil pra custar menos. Pra você poder atingir esse público. Porque esse público, até dez anos atrás, a classe C e D comprava fogão usado em lojas de produtos usados ou então comprava da vizinha. Há dez anos atrás começou a vender fogão nas Casas Bahia, no Magazine Luiza, em dez vezes sem juros. Aquele fogão que custa 5 mil reais ele é um "tanquezinho", ele é todo reforçado, cheio de componentes de segurança, cheio de sítios eletrônicos. Aquele de primeiro preço que custa 400 reais tem só um sisteminha de segurança se o gás começar a vazar, e são válvulas com chama, não tem isolamento térmico, não tem vidro duplo, então ele esquenta todo. Você pergunta “ele funciona?”. Sim, ele funciona, ele dá pra cozinhar, dá pra fazer pão no forno, dá pra fazer tudo no forno, do jeito que o outro faz, mas ele é mais "simplesinho".
\end{abstract}

Na fala do designer, também é possível notar que, além da mudança nos materiais citada anteriormente, há uma ampliação do mercado consumidor, incluindo nele as classes C e D, antes não tão contempladas.

O barateamento dos produtos os torna mais acessíveis a uma parcela maior da população, mas, por outro lado, o fato de haver uma redução de seu preço e barateamento dos materiais, conforme visto nas entrevistas, compromete sua durabilidade. Cada vez mais os artefatos são produzidos nesta lógica de baratear os custos para concorrer com produtos que vêm da China, como pôde ser lido nas entrevistas e também nos questionários.

Na época da implementação da obsolescência programada, como foi visto na revisão da literatura, foi preciso introduzir na vida das pessoas o conceito de descartável, pois durabilidade era então um grande fator para a escolha de produtos. Hoje, ainda que muitos dos participantes da pesquisa afirmem que durabilidade é algo importante na hora da compra, ela é algo que passou a ser relativizado por contrapor-se à tecnologia ou por haver uma experiência tão recorrente com quebras ou impossibilidade de uso dos equipamentos que acaba havendo, de certa maneira, uma descrença de sua existência. O depoimento de um dos participantes que afirma "que tudo vai quebrar mesmo" ou da internauta que relata a diferença de opinião entre ela e seu marido mostram as diferentes aceitações da obsolescência programada. Dessa maneira, para aqueles que tratam o fenômeno como algo estabelecido e generalizado, o fator de escolha passa a ser o preço, e descartabilidade dos produtos é uma consequência natural dele. Contribui para isso também a descrença relatada por muitos participantes da pesquisa na assistência técnica, como veremos mais a seguir.

${ }^{60}$ Segundo Gama, Consul e Brastemp juntas fazem 140 mil fogões por mês, enquanto a Esmaltec sozinha faz 230 mil. 


\subsubsection{Assistência técnica}

Entre os 444 participantes da pesquisa, 250 afirma levar em conta a assistência técnica do produto na hora da compra. Há uma associação entre renda familiar e a importância da assistência técnica conforme mostra o Gráfico $3 .{ }^{61}$

\section{Gráfico 3}

Associação renda familiar mensal e relevância da assistência técnica

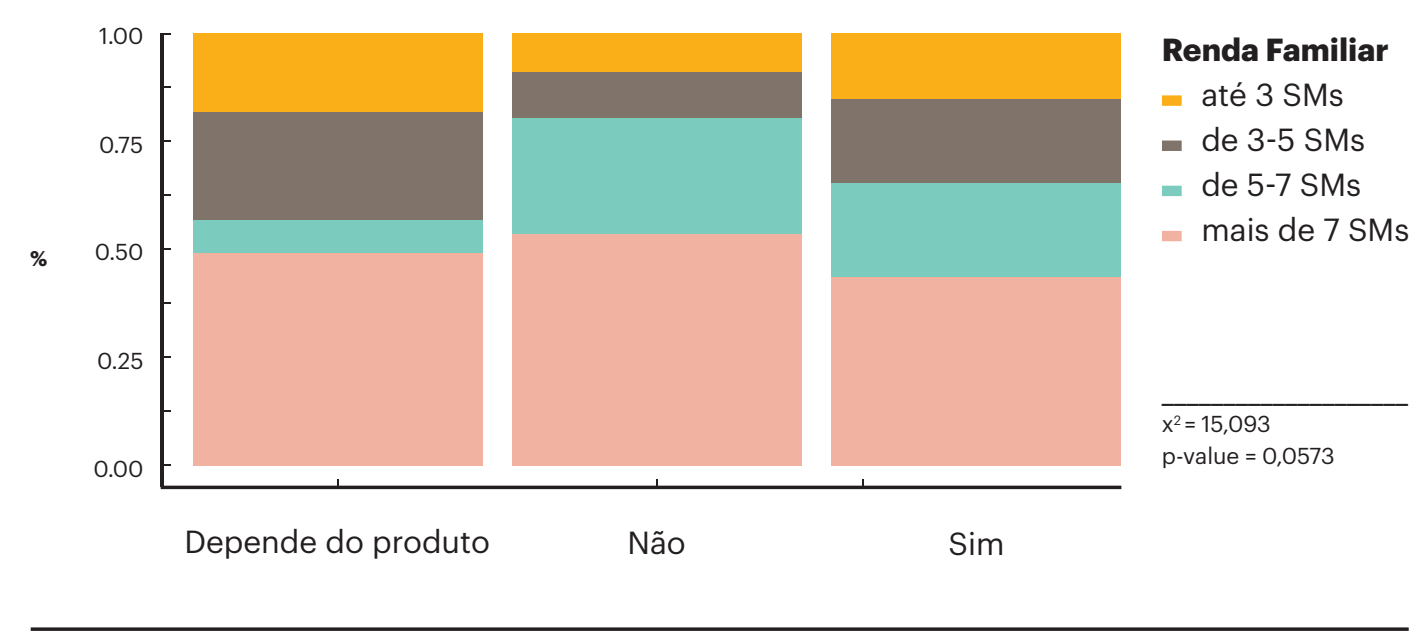

Fonte: elaborado por Eduardo Lazzari, a partir de dados do questionário, 2017.

No gráfico, é possível perceber que quanto maior a renda menor a importância da assistência técnica, já que o segmento de cada renda é progressivamente maior na coluna daqueles que afirmaram que a assistência não é importante.

Entre os que responderam que não é importante, muitos afirmam não considerar isso especificamente na hora da compra, ainda que façam uso de assistência técnica de maneira geral. Também foram registrados muitos depoimentos de experiências ruins, que levam a uma descrença na assistência técnica, fazendo com que ela não seja importante, como é possível ler a seguir: "Pra dizer a verdade, não confio nas assistências técnicas, sempre exploradores”, ou então

${ }^{61}$ Sobre renda familiar, é necessário frisar que, pela distribuição dos respondentes ser assimétrica, concentrada nos estratos com maior poder aquisitivo, reorganizamos os respondentes em quatro categorias diferentes. A primeira é composta por indivíduos que estão em famílias que auferem até três salários mínimos, a seguinte composta por domicílios que têm entre três e cinco salários mínimos, a próxima entre cinco e sete enquanto a última congrega todos aqueles que recebem mais de sete salários mínimos (LAZZARI, 2017, p. 29). 
Sinceramente, nunca tive uma boa experiência com assistência técnica. Na minha concepção, todas são péssimas, não tendo peça de produtos que foram comprados há menos de um ano, muitas sem a mínima vontade de consertar o produto. Pra mim não interfere, porque ainda não conheci uma que seja boa.

Entre os que responderam "sim" sobre a assistência técnica ser algo importante na hora da compra, 55 não moram no estado de São Paulo. Entre os 61 que comentaram suas respostas, dez afirmam que a assistência técnica é determinante por morarem fora dos grandes centros, como é possível ler no depoimento: "Só compro se tiver assistência técnica na minha cidade", de um respondente que mora em no interior do estado de São Paulo. Porém, também em grandes centros, isso pode ser um problema, conforme o depoimento a seguir: "já tive problemas com um produto que não tinha assistência técnica na minha cidade, sendo que o Rio de Janeiro é a segunda maior cidade do Brasil". Outros afirmam ser algo importante, ainda que pouco acessível ou pouco confiáveis, como se lê nos depoimentos a seguir: "seria, mas dificilmente levamos isso em consideração, e essa informação não está muito disponível” ou então “é importante, mas já não tenho esperanças em relação a assistências técnicas". Há apenas um depoimento de um participante que se mostra totalmente satisfeito com a assistência técnica: "sempre uso a assistência técnica, que já me poupou de ter que comprar novos equipamentos".

Entre os 42 que responderam "depende do produto", treze depoimentos atrelam a preocupação com a assistência técnica a produtos mais caros, que muitas vezes têm uma expectativa de durabilidade maior, como mostra o exemplo: "quanto maior o valor do produto maior a importância da assistência".

No entanto, é curioso notar que muitos depoimentos se assemelham, apesar da alternativa escolhida pelo respondente, conforme os relatos a seguir (entre parênteses, está a alternativa selecionada pelo respondente):

Fundamental ter assistência técnica para bens duráveis. O que mais irrita é descobrir que a fabricação foi descontinuada, não existem peças de reposição e que o conserto ficará praticamente o custo de um produto novo. (Sim)

odeio as assistências técnicas. São feitas para roubar o seu dinheiro. (Sim)

Já tive problemas com um produto que não tinha assistência técnica na minha cidade, sendo que o Rio de Janeiro é a segunda maior cidade do Brasil. Não compro mais essa marca. (Sim)

Raramente uso assistência técnica. As poucas vezes que tentei usar me trouxe maior prejuízo. Exemplo, um computador quebrou, tive que mandar arrumar e estava na garantia. $O$ prazo eram 
30 ou 40 dias úteis. Achei absurdo mas não tinha alternativa. Quando voltou estava com a tela quebrada. Tive que fazer todo o processo de novo. Era meu computador de trabalho e tive que comprar um menor mais simples temporário porque não tinha como ficar quatro meses quase sem ele. Tive algumas experiências desse tipo. Por isso não observo as garantias que o produto oferece. Se ele é caro como um computador tenho que tentar arrumar. Se fosse um liquidificador por exemplo possivelmente eu compraria outro. (Não)

Há situações que é tão desgastante ou complicado que é preferível trocar o produto. (Depende) Há tanta burocracia que desestimula. (Depende)

Nota-se nos depoimentos uma frustração com assistências técnicas de maneira geral, seja por oferecer serviços caros ou demorados, seja por não ser eficiente para produtos mais antigos, que eventualmente foram descontinuados ou ainda por ser difícil de ser encontrada.

Isso pode ser visto também no Gráfico 4, que mostra os problemas enfrentados pelos 226 participantes da pesquisa que afirmaram ter procurado uma assistência técnica, mas ainda assim tiveram que adquirir um produto novo. A pergunta do questionário (P41) era "caso tenha quebrado e tentou consertar, mas ainda assim teve que comprar um novo, o que não deu certo?”. Possuía cinco campos de múltipla escolha, um campo com a alternativa "não se aplica" (válida principalmente para produtos trocados que não tenham quebrado) e um campo aberto, caso o respondente não encontrasse nenhuma alternativa que se identificasse.

\section{Gráfico 4}

Motivos por não ter sido possível consertar

O conserto era muito caro

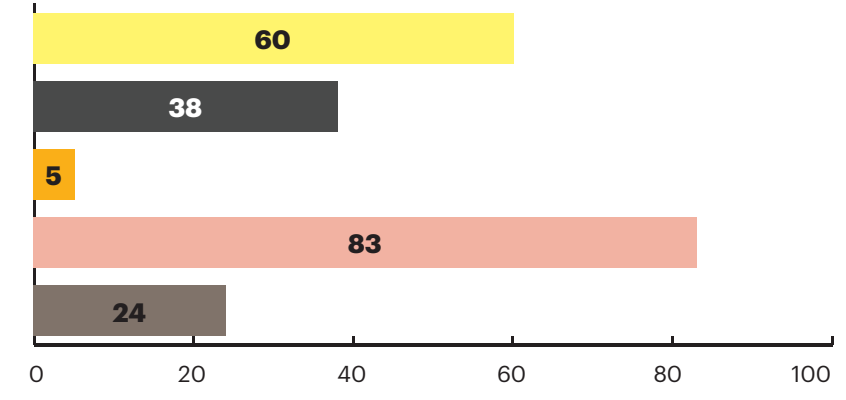

Falta de peças

Demoraria muito

Valia mais a pena comprar um novo

Não encontrei nenhuma

assistência técnica que consertasse 
É possível observar no gráfico que a maioria dos respondentes acabou optando por não consertar seus equipamentos pelo fato de o conserto ser oneroso demais ou por não valer a pena consertá-lo. Dificuldade ou impossibilidade de conserto são fortes indicativos da obsolescência artificial, conforme descrito por Packard no capítulo de revisão da literatura e como pode ser observado também no gráfico acima. Os dados relacionados à quebra dos equipamentos serão tratados de maneira mais detalhada no item 4.2.1, sobre obsolescência artificial.

Entre as entrevistas, somente a GM mostrou-se preocupada com a assistência técnica no desenvolvimento de produtos. Segundo o entrevistado, "tem a maior briga com concessionárias para ter um atendimento bom, para ter serviço barato, então é superpadronizado". Isso porque na sua opinião "o foco é o cliente ficar satisfeito e o serviço estar adequado à expectativa dele". Na Falmec, a assistência técnica é terceirizada, mas tem treinamento dentro da fábrica para fazer tudo da maneira correta. Na Samsung, ela entra mais como um item obrigatório por lei do que como algo importante para a empresa.

Resultado similar foi obtido na pesquisa realizada em 2013 pelo Idec e o Market Analysis que averiguou hábitos de consumo dos brasileiros no que diz respeito ao ciclo de vida dos produtos, dado diretamente ligado à obsolescência programada. Por sua presença na maioria nos lares brasileiros, foram pesquisados os seguintes equipamentos: celulares, computadores (incluindo portáteis), DVD players ou blu-ray players, câmeras fotográficas digitais, televisores, impressoras, micro-ondas, geladeiras/freezers, lavadoras de roupa e fogões. Uma das conclusões da pesquisa foi a de que "assistência técnica mostrou-se pouco utilizada devido a dificuldades de realização do conserto, tempo elevado para realizá-lo, valores altos cobrados e falta de garantia. Segundo a pesquisa, todos estes motivos não incentivam o conserto dos equipamentos e acabam por estimular a compra de um novo" (IDEC; MARKET ANALYSIS, 2013, p. 61).

Muitas das estratégias que viabilizaram a implementação da obsolescência programada na década de 1920, descritas por Packard em 1965, foram identificadas também por Slade já como práticas de consumo e mecanismo de produção de artefatos de maneira mais elaborada em 2007, conforme pôde ser visto na revisão da literatura.

Na coleta de dados foi possível identificar a maioria delas:

- Crédito. Alto índice de pessoas que realizam compras em poucas ou muitas parcelas.

- Durabilidade. Com relação aos produtos, mostrou-se inferior à expectativa dos participantes. Confrontada com tecnologia, muitos participantes, sobretudo os 
que se referiram a celulares, afirmaram que durabilidade deixa de ser algo importante na aquisição de novos produtos ou deixa de ser algo viável, uma vez que a tecnologia evolui muito rapidamente.

- Associação dos conceitos barato-frágil, apontando para uma naturalização da fragilidade dos produtos de acordo com os respondentes do questionário. Nas entrevistas, vale destacar, a questão dos materiais é apontada como determinante na redução dos custos, trazendo benefícios por um lado, mas uma durabilidade menor por outro.

- Dificuldade de conserto dos equipamentos, que muitas vezes gera uma descrença na assistência técnica que se mostra ineficiente ou onerosa demais, estimulando também a compra de novos produtos tornando-os, de certa maneira, descartáveis.

A valorização do conceito de "novo" fica menos clara na coleta de dados do que na descrição de Packard (1965). Isso porque "novo", atualmente, vem atrelado muitas vezes a tecnológico, o que para alguns traz características positivas, como redução de consumo energético ou variedade de funções, enquanto para outros indica uma dificuldade de consertos.

Porém, pode-se afirmar que para a população estudada, novo não é um conceito tão procurado. Isso porque a maioria dos respondentes declara não comprar produtos por ser um lançamento, assim como procurar sempre consertar seus produtos ao invés de trocá-los. No mesmo sentido, grande parte dos respondentes discorda da frase “o que é novo é bom, o que é velho é ruim”, e, como veremos a seguir, apenas quatro respondentes afirmaram adquirir produtos somente por se tratar de um lançamento (os quatro concordam com a frase “o que é novo é bom, o que é velho é ruim”).

Como visto anteriormente, além das práticas de consumo listadas na revisão da literatura, foram observadas também outras associações: novo associado a frágil; durabilidade associado a materiais e contraposta a tecnologia; preço/custo associado a materiais, tecnologia, marca, acessórios.

Apresentaremos a seguir os produtos mais citados na pesquisa e de que maneira se relacionam com os tipos específicos de obsolescência programada. 


\subsection{Principais produtos citados na coleta de dados e tipos de obsolescência programada identificados}

Os participantes da pesquisa foram perguntados especificamente sobre produtos de duas maneiras diferentes. A primeira relacionava-se com a última compra efetuada ou a considerada importante nos últimos meses, e, sobre esta compra especificamente, outras perguntas a respeito de durabilidade e motivo de aquisição foram feitas. A segunda relaciona-se aos produtos trocados com maior frequência em suas casas. Nos dois casos, o celular foi o produto mais citado. Entre as últimas aquisições realizadas, depois do celular, os mais citados foram notebook, geladeira e máquina de lavar roupas, e entre as trocas frequentes, apesar de 42 dos participantes afirmar não trocar produtos com frequência, depois do celular, os mais citados foram itens relacionados ao vestuário, seguidos de computadores (desktop e laptop) e acessórios relacionados a eles (tais como fios, fones ou carregadores de bateria).

Na sondagem em rede social, celular e notebook também lideraram a lista dos produtos mais citados, também seguido por computador desktop e secador de cabelos em terceiro e quarto lugar.

O Quadro 2 mostra detalhadamente os produtos mais citados na pesquisa e o número de vezes que foi citado. Considerando o fato de a grande maioria dos participantes conhecer o termo obsolescência programada - seja por parte da coleta ter sido feita em uma página que tratava do assunto e o questionário ter sido divulgado nesta mesma página -, é possível dizer que os produtos mais citados são os mais associados à obsolescência programada.

O fato de escova de dentes, isqueiro e lâmpadas terem sido citados no questionário, ainda que por apenas um participante, chama a atenção para uma confusão que normalmente se faz entre obsolescência programada e artefatos descartáveis. Porém, ainda que não seja intenção desta pesquisa se aprofundar nestes itens ou neste tema, vale destacar a associação que se faz entre os dois temas, pois, como visto no capítulo 2, a obsolescência programada não poderia ter se consolidado caso a ideia de descartabilidade não tivesse vindo antes dela. Na página do Facebook também houve um comentário nesse sentido: o participante pergunta se o guarda-chuva pode ser associado à obsolescência programada e descreve sua experiência com as diversas trocas de produto realizadas. Outro participante faz a mesma pergunta sobre as raquetes que eletrocutam pernilongos e são vendidas nos semáforos de São Paulo. Não é possível afirmar que os produtos citados figurem na lógica da obsolescência programada, principalmente por não terem características que o enquadrem em nenhuma das ob- 


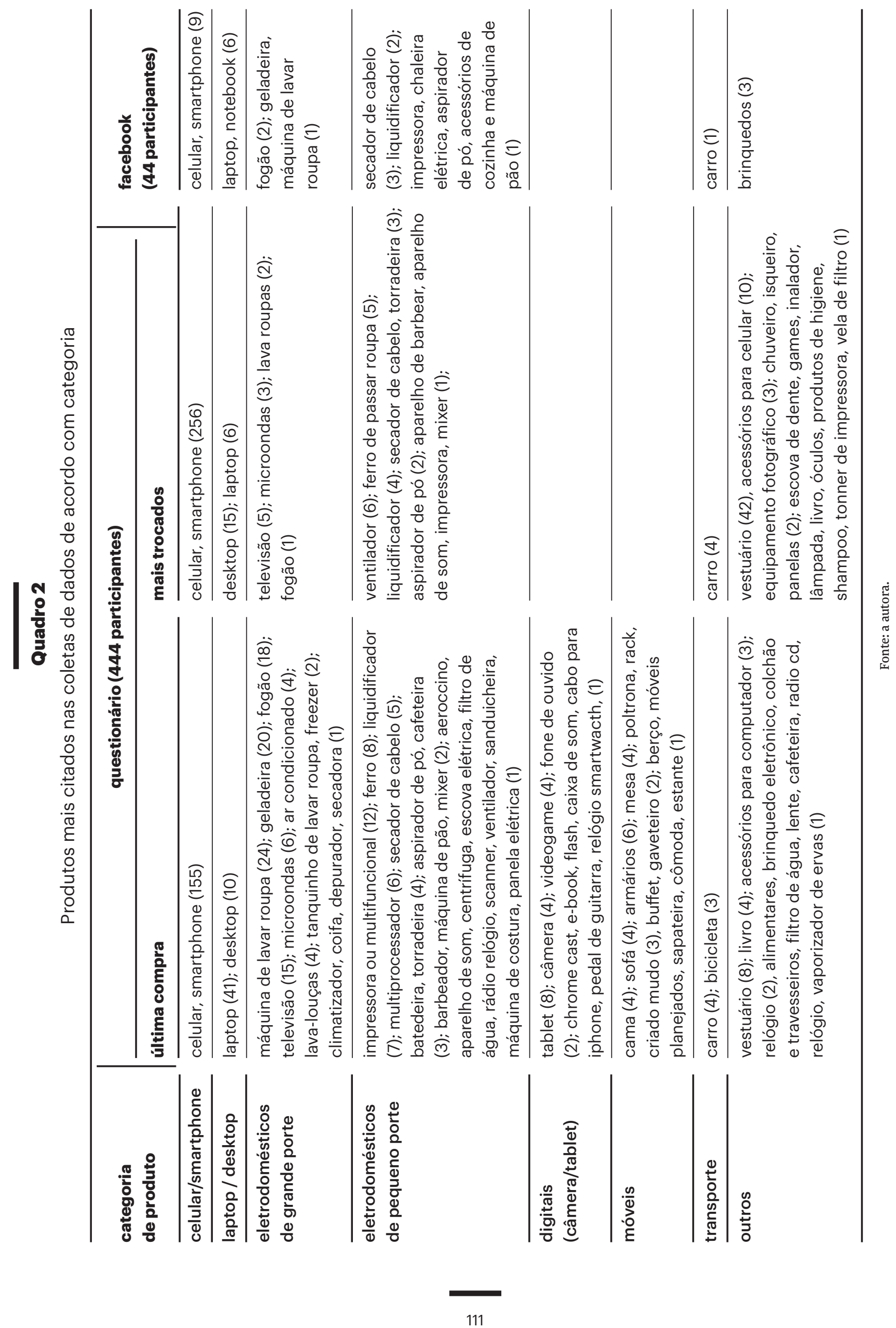


solescências tratadas neste trabalho: não há manutenção possível, não há um novo lançamento que faça o anterior tornar-se obsoleto, assim como não há uma evolução tecnológica que impossibilite seu uso. Há um uso de materiais mais frágeis com a intenção de torná-los baratos que entra na lógica do consumo repetido e do descartável, da mesma maneira que essas duas lógicas relacionam-se com a obsolescência programada. Porém, nem tudo que figura nesta lógica é obsolescência programada no entendimento desta pesquisa.

Como a pesquisa procura identificar relações entre produtos e tipos de obsolescência programada, consideraremos nos próximos gráficos e tabelas apenas os produtos adquiridos novos, uma vez que produtos adquiridos usados carregam uma certa consciência de reutilização por não estar necessariamente atrelado a um poder aquisitivo mais baixo, como visto no Gráfico 3 .

Os participantes da pesquisa também foram perguntados a respeito dos produtos mais antigos em uso. Entre os mais antigos em uso estão geladeira, televisão, móveis, computador e máquina de lavar roupa.

Apesar de 128 dos participantes terem afirmado não possuir itens deste tipo, pois não guardam produtos que não funcionam mais, os que foram citados como mais antigos sem uso foram: computador, celular, câmera fotográfica, notebook e aparelho de som (em sua maioria, vitrolas).

Segundo Lazzari (2017), produtos diferentes são adquiridos por motivos diferentes, ou seja, por obsolescências diferentes, conforme pode ser visto no Gráfico 5, que considerou somente compras de produtos novos. 


\section{Gráfico 5}

Associação do bem adquirido e o motivo da aquisição

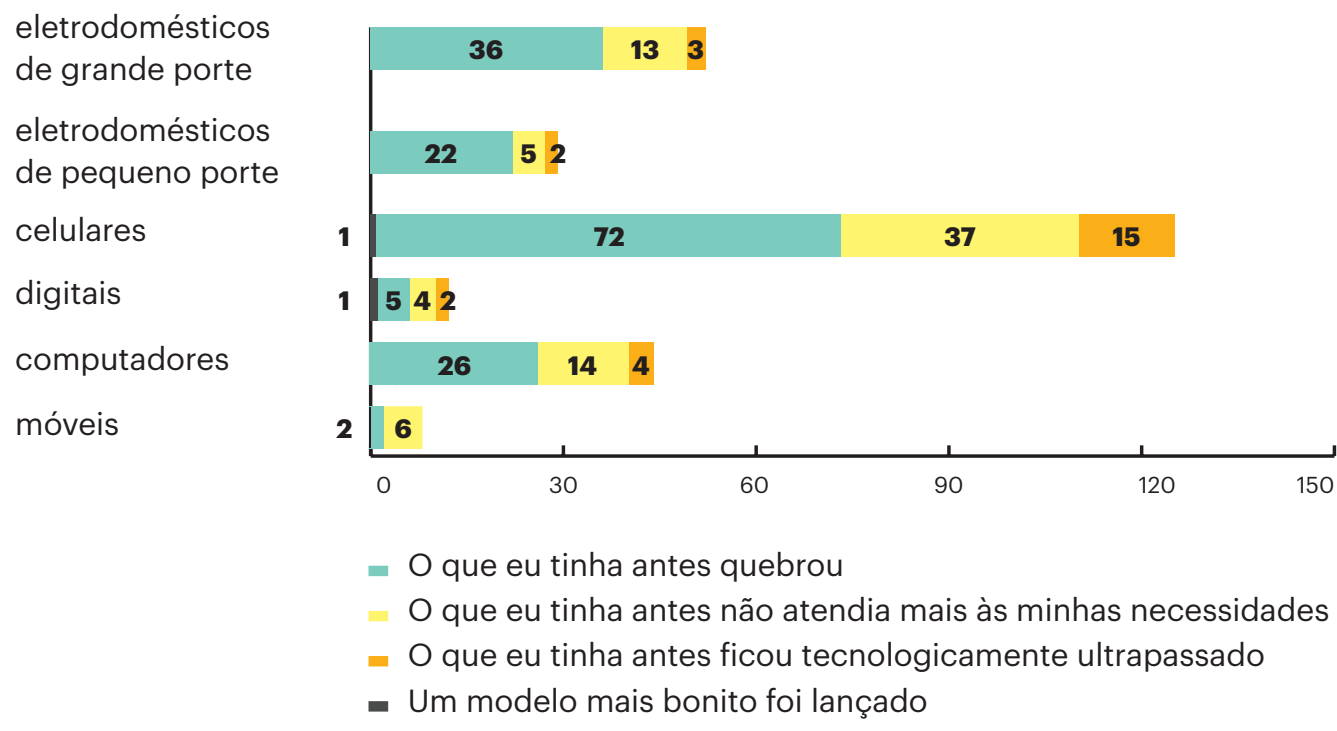

Fonte: elaborado por Eduardo Lazzari, a partir de dados do questionário, 2017.

É possível observar no Gráfico 5 que o produto mais citado foi o celular, e o fato do aparelho anterior ter quebrado é o motivo principal para a nova compra. Não atender mais às necessidades do participante é a segunda razão que motivou a troca. Computadores são adquiridos pelas mesmas razões que os celulares. Já para eletrodomésticos de grande porte, o principal motivo pelo respondente ter comprado um foi o anterior ter quebrado. Para eletrodomésticos de pequeno porte, assim como para eletrônicos, a compra ocorreu na maioria das vezes pelo fato de o respondente não possuir um e o mesmo motivo pôde ser observado para a compra de móveis.

Relacionada com o último produto adquirido ou a última compra que o respondente considerasse importante, a pergunta 34 do questionário (“por que motivo comprou?") tem papel importante na identificação dos tipos de obsolescência definidos na primeira etapa da pesquisa. As alternativas apresentadas como opção de resposta relacionam-se com as práticas de consumo atribuídas aos tipos estabelecidos de obsolescência programada, conforme o Quadro 1, apresentado no capítulo 2 desta dissertação.

A distribuição das respostas dos participantes do questionário pode ser observada no Gráfico 6, onde se lê que o principal motivo da compra se deve ao produto anterior ter quebrado. 


\section{Gráfico 6}

Motivo da compra de produtos novos (399 respondentes)

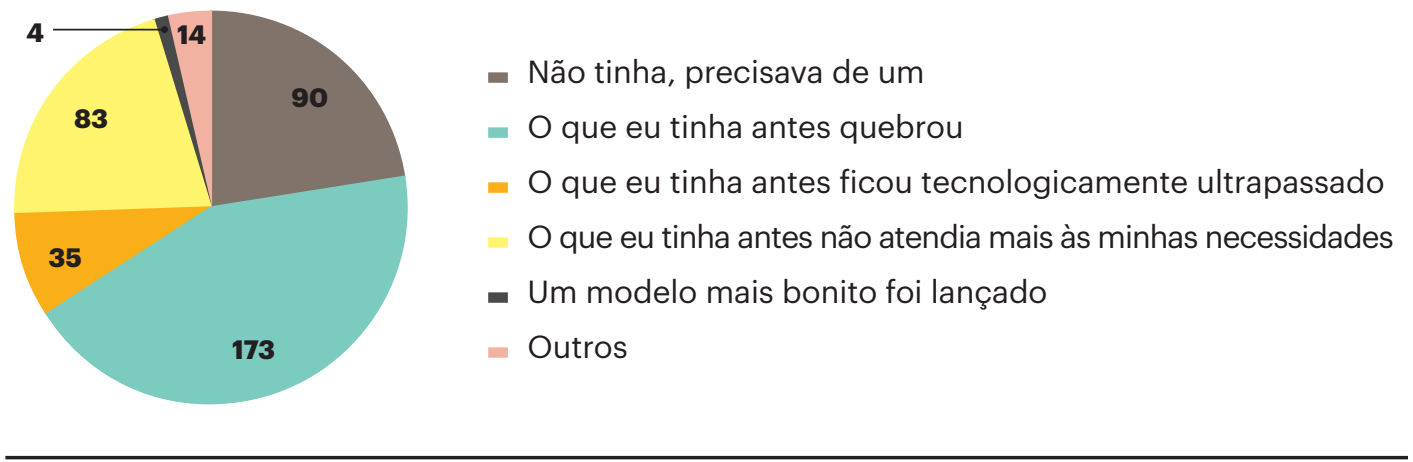

Fonte: elaborado por Eduardo Lazzari, a partir de dados do questionário, 2017.

Entre os 82 participantes da pesquisa que atrelaram a compra do novo equipamento ou a última considerada importante ao fato de o anterior não atender mais às suas necessidades, dezoito não têm relação com a obsolescência programada, seja por ter acontecido por alguma mudança na família ou na casa ou por um desgaste natural do produto. Porém, analisando-se as respostas detalhadamente é possível afirmar que:

- Treze referem-se à obsolescência artificial e são em sua maioria celulares e eletrodomésticos de grande porte. Muitas vezes nos depoimentos aparece uma tentativa de conserto sem sucesso ou problemas com partes dos equipamentos (baterias no caso dos celulares ou um botão do micro-ondas no caso dos eletrodomésticos, por exemplo).

- 51 referem-se à obsolescência tecnológica, seja pelo fato de o equipamento ter ficado lento ou incapaz de receber atualizações no caso dos eletrônicos, celulares e computadores, seja no caso de uma nova tecnologia ter surgido, como no caso da televisão de alta definição. Um exemplo é o respondente que justificou sua última troca de celular a "pouco espaço para o tanto de coisas que somos obrigados a ter num celular, para continuarmos atuantes/vivos no mundo moderno (banco, Zona Azul, troca de arquivos etc)". A obsolescência tecnológica exclui, pois impossibilita algumas ações.

Analisando-se as respostas mais detalhadamente, ainda que a última compra realizada ou a última considerada importante tenha sido motivada pelo respondente não possuir um anteriormente, em muitos casos surgiram descrições de outras compras relacionadas com obsolescência programada nos campos abertos que se sucederam. Um respondente, por exemplo, afirmou ter comprado geladeira, máquina de lavar e fogão novos por não ter e precisar de um, escrevendo no campo aberto a seguir: "Comprei um aspirador de pó e com pouco tempo de uso parou de funcionar, sem motivo aparente”. 
Outros dois exemplos são de respondentes que assinalaram ter comprado móveis por não possuir e precisar deles e escreverem a seguir no campo aberto: "Meu celular quebrou a tela, o valor para consertar era quase o preço de um novo" e "smartphone de última geração apresentou vários problemas no display". Ou seja, ainda que sua última compra não tenha tido relação direta com a obsolescência programada, o respondente acabou por lembrar-se de outra situação que tivesse. Os três exemplos citados são de situações relacionadas com a obsolescência artificial.

Entre os motivos para a última compra realizada ou a última considerada importante, averiguou-se que a alternativa "não tinha, precisava de um" não tem relação com a obsolescência programada. Da mesma maneira, como visito anteriormente, a alternativa "não atendia mais às minhas necessidades" mostrou-se mais relacionada com a obsolescência tecnológica. Assim, no Gráfico 7 aparecem somente as opções de resposta que estão relacionadas ao fenômeno estudado. Conforme dito anteriormente, foram considerados apenas os produtos adquiridos novos.

Assim, o Quadro 3 apresenta as alternativas de resposta à pergunta 34 do questionário e sua associação com os tipos de obsolescência programada definidos na primeira etapa da pesquisa.

\section{Quadro 3}

Motivo da compra relacionado com os tipos de obsolescência programada

Opção de resposta

Não tinha, precisava de um

O que eu tinha antes não atendia mais

às minhas necessidades

Um modelo mais bonito foi lançado

e decidi comprá-lo

O que eu tinha antes quebrou

O que eu tinha antes ficou

tecnologicamente ultrapassado
Tipo de obsolescência

a que se relaciona

não se encaixa

na obsolescência programada

obsolescência tecnológica

ou artificial

obsolescência psicológica

obsolescência artificial

obsolescência tecnológica

Fonte: a autora.

Vale destacar no Gráfico 6 que $22 \%$ assinalaram ter comprado um novo por não possuir o produto, dado que não se relaciona com a obsolescência programada. 


\section{Gráfico 7}

Motivo da compra de produtos novos relacionado com os tipos de obsolescência programada (295 respondentes).

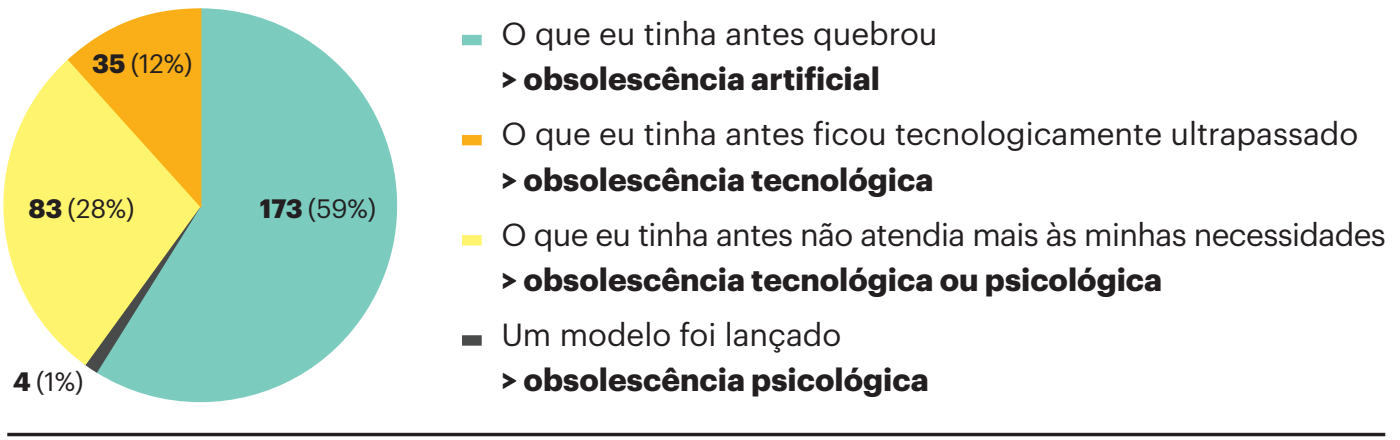

Fonte: elaborado por Eduardo Lazzari, a partir de dados do questionário, 2017.

Observa-se, tanto no Gráfico 6 como no Gráfico 7, que a maioria dos respondentes do questionário associou a nova compra à quebra de seu equipamento. Não é possível afirmar que os produtos tenham sido feitos propositalmente para quebrar, e as questões de escolha de materiais para baixar os custos também comprometem sua durabilidade ainda que não sejam escolhas com o propósito de encurtar a vida dos produtos. Muitas vezes, porém, a dificuldade ou a impossibilidade do conserto acaba por induzir a troca de produtos, e essa prática se atrela à obsolescência artificial. Analisando-se atentamente os depoimentos dos participantes, é possível identificar padrões relacionados com a obsolescência artificial (como dificuldade de conserto), ainda que uma minoria dos depoimentos trate de quebras ocorridas por um desgaste natural do equipamento, acidente ou roubo.

Assim, nesta pesquisa, pode-se constatar uma maior presença da obsolescência artificial, seguida pela obsolescência tecnológica e, por fim, a psicológica.

Os dados diferem dos levantados pela pesquisa do Idec e do Market Analysis, cuja conclusão é a de que as principais motivações que levam à substituição de equipamentos no mercado brasileiro são a obsolescência psicológica, em primeiro lugar, seguida pela obsolescência artificial (chamada de funcional na pesquisa), como pode ser visto no Gráfico 8. 


\section{Gráfico 8}

Motivações para a troca na pesquisa do IDEC

\begin{tabular}{|c|c|c|c|}
\hline digitais * & $53 \%$ & & $25 \%$ \\
\hline eletrônicos & $52 \%$ & $13 \%$ & $33 \%$ \\
\hline celular & $46 \%$ & $21 \%$ & $33 \%$ \\
\hline \multirow[t]{2}{*}{ eletrodomésticos } & $42 \%$ & $30 \%$ & $28 \%$ \\
\hline & \multicolumn{3}{|c|}{$\begin{array}{l}\text { o novo era mais atual, moderno, melhor ou com mais funções } \\
\text { o antigo até funcionava, mas apresentava alguns defeitos } \\
\text { o antigo não funcionava mais }\end{array}$} \\
\hline
\end{tabular}

Fonte: IDEC: MARKET ANALYSIS, 2013.

A diferença dos resultados pode ser atribuída ao meio eletrônico que o questionário foi veiculado e à população atingida, conforme já discutido anteriormente. Por outro lado, pode ser um indicativo de que a população estudada nesta pesquisa (majoritariamente feminina, paulista, com alto poder aquisitivo, alta escolaridade e grande consciência sobre a obsolescência programada) está mais suscetível à obsolescência artificial, enquanto a amostra da pesquisa do Idec e Market Analysis, que traz resultados mais gerais sobre a população brasileira, está mais suscetível à obsolescência psicológica.

A seguir, trataremos mais detalhadamente dos tipos de obsolescência encontrados na coleta de dados.

\subsubsection{Obsolescência artificial}

Foram 171 os participantes que assinalaram ter comprado um equipamento novo devido ao fato de $o$ anterior ter quebrado.

Entre eles, setenta referiam-se à compra de um novo celular, e os motivos para a nova compra podem se resumir a: tela que quebrou devido à queda, bateria que não carregava mais, sistema operacional lento sem conseguir realizar funções básicas ou rodar aplicativos, além de acidentes ou quebras inexplicáveis, algumas vezes num período nem tão curto de tempo que podem estar associadas a um desgaste natural do produto. Vale destaque um dos depoimentos que descreve a vontade de conservar o dispositivo:

* Na pesquisa foram cosiderados como eletrodomésticos: fogão, geladeira, lavadora de roupas, microondas; digitais: câmera fotográfica, impresora, computador; eletroeletrônicos: dvd ou blue ray, televisão. (IDEC; MARKET ANALYSIS, 2013) 
Levei ele na manutenção, pois a bateria não estava segurando a carga, após fazer manutenção e pagar pela bateria, com um custo total de aproximadamente 160 reais pela manutenção, ele apresentou o mesmo problema seis meses depois, então decidi adquirir outro aparelho.

Entre os computadores são recorrentes as queixas de inviabilidade ou alto valor do conserto, como se lê no depoimento de um participante que alega que "o conector do barramento do teclado descolou da placa. Não encontrei quem pudesse recuperá-lo, mesmo indo em inúmeras assistências técnicas".

Entre os eletrodomésticos de grande porte, chama atenção o tempo de duração elevado dos depoimentos. Entre os 38 produtos citados, a média de uso foi de nove anos, e a grande queixa para a inviabilidade de conserto se deveu à falta de peças.

O artigo 32 do Código de Defesa do Consumidor estabelece que fabricantes e importadores devem assegurar a oferta de componentes e peças de reposição enquanto houver fabricação ou importação do produto. Quando, por qualquer razão, não houver mais produção ou importação de produtos, fabricantes e importadores devem manter a oferta por "período razoável de tempo, na forma da lei" (BRASIL, 1990). Porém, como afirma Freitas (2017), não são muitos os consumidores que buscam reparação junto ao Poder Judiciário, parte por não saber seus direitos, parte por nem sequer procurar assistência técnica quando surge um defeito no aparelho adquirido. A pesquisa do Idec e do Market Analysis (2013) mostra que 81\% dos consumidores trocaram seu celular sem procurar assistência técnica para saber se seria possível repará-lo. No caso dos eletroeletrônicos, foram $44 \%$ os que agiram da mesma maneira, enquanto no caso de eletrodomésticos e digitais foram $23 \%$ e $27 \%$ respectivamente que trocaram seus equipamentos sem procurar a assistência técnica.

O monitoramento da página do Facebook também trouxe resultados interessantes. Uma das pessoas comentou por exemplo, da recente experiência de oscilação de energia em sua casa, que fez quebrar diversos eletrodomésticos, o que a fez experimentar a dificuldade e o custo elevado de conserto, conforme relato:

Eu levei ou chamei técnicos pra todos os itens. Assistência autorizada (levei em mais de uma alguns dos itens) diziam sempre a mesma coisa, que não tem conserto e ou que era mais caro consertar do que comprar algo (exemplo, o processador de alimentos custava $\mathrm{R} \$ 350,00$ pra trocar o botão de ligar e desligar e levava 60 dias ou mais pra chegar a peça).

Outro comentário que vale destaque, é o de uma pessoa que comentou do hábito de comprar lanches em determinada lanchonete, que tem pequenos brinquedos como brinde. Segundo seu relato todos têm som e em pouco tempo ficam sem bateria. 
Já tentei abrir uns dois e não sei porque o fabricante usa um parafuso triangular e não um Philips ou de fenda comum para que possamos substituir as baterias e manter o brinquedo funcionando, já procurei em várias lojas que são especializadas em ferramentas e não consigo encontrar essa tal chave triangular, encontrei em um joguinho de chaves que usei uma vez e a chave estragou e não consegui trocar a bateria do brinquedo sem dizer que em alguns brinquedos $o$ parafuso fica tão fundo que mesmo se comprasse outro joguinho a chave não alcançaria.

Sobre brinquedos, também outra pessoa comenta seu espanto: "quando ganham, em geral são caros, não resistem a uma semana sem perder uma roda”.

A prática da Apple de fazer produtos com parafusos também diferenciados, como no exemplo anterior, levou a criação de uma empresa chamada iFixit, ${ }^{62}$ que vende conjuntos de ferramentas que possibilitam que um consumidor comum possa abrir e reparar seus equipamentos. A empresa disponibiliza também tutoriais que ensinam reparos e trocas de partes internas dos equipamentos.

Assim como os exemplos acima, a maioria dos relatos na página também aborda a impossibilidade de conserto ou seu custo elevado, o que acabou por estimular a compra de um equipamento novo. Ambos os comentários se encaixam nas estratégias do desperdício expostas no capítulo de revisão da literatura desta dissertação e no que define Packard (1965, p. 45): “em alguns casos os consumidores não tem alternativa senão ser fabricantes de lixo devido à maneira como os produtos lhe são vendidos".

É curioso traçar aqui um paralelo entre os produtos mais citados nesta pesquisa e os produtos mais citados em uma pesquisa feita em 1957 pela publicação Home Furnishings Daily, na qual foi feito um ranking dos produtos com mais queixas de se quebrarem. A lista, reproduzida aqui em ordem decrescente, foi elaborada a partir do depoimento de 127 revendedores de aparelhos domésticos da época, que citaram os aparelhos mais devolvidos semanas ou meses após a compra (PACKARD, 1965, p. 51): máquinas de lavar roupa, refrigeradores, secadores de roupa, televisores, combinações de lavadeira e secador, fogões, aparelhos de ar condicionado, congeladores.

É possível observar que, apesar dos 56 anos que separam as pesquisas, entre os eletrodomésticos de grande porte mais citados no questionário estão: máquina de lavar roupa, geladeira, fogão e televisão. É também curioso observar as semelhanças entre os produtos ilustrados nas Figuras 2 a 6. Os objetos se assemelham bastante, tendo diferenças de estilos, mas características formais semelhantes. No caso da geladeira, até a maneira como ela é fotografada se assemelha. 

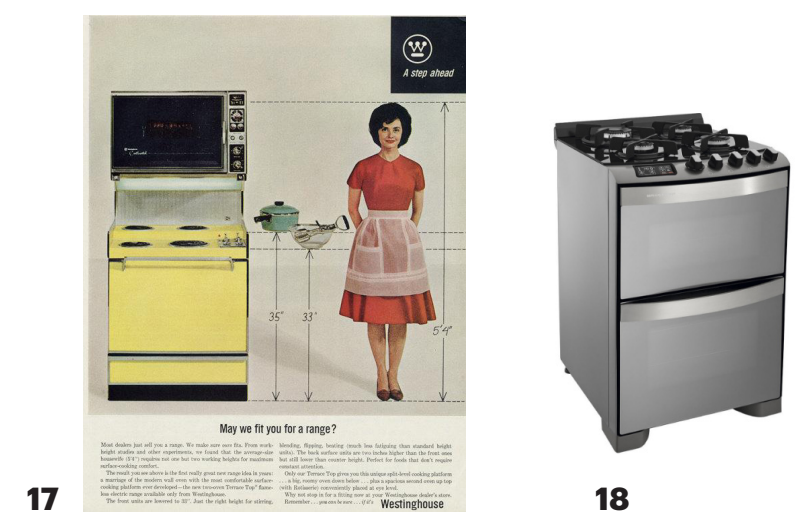

18
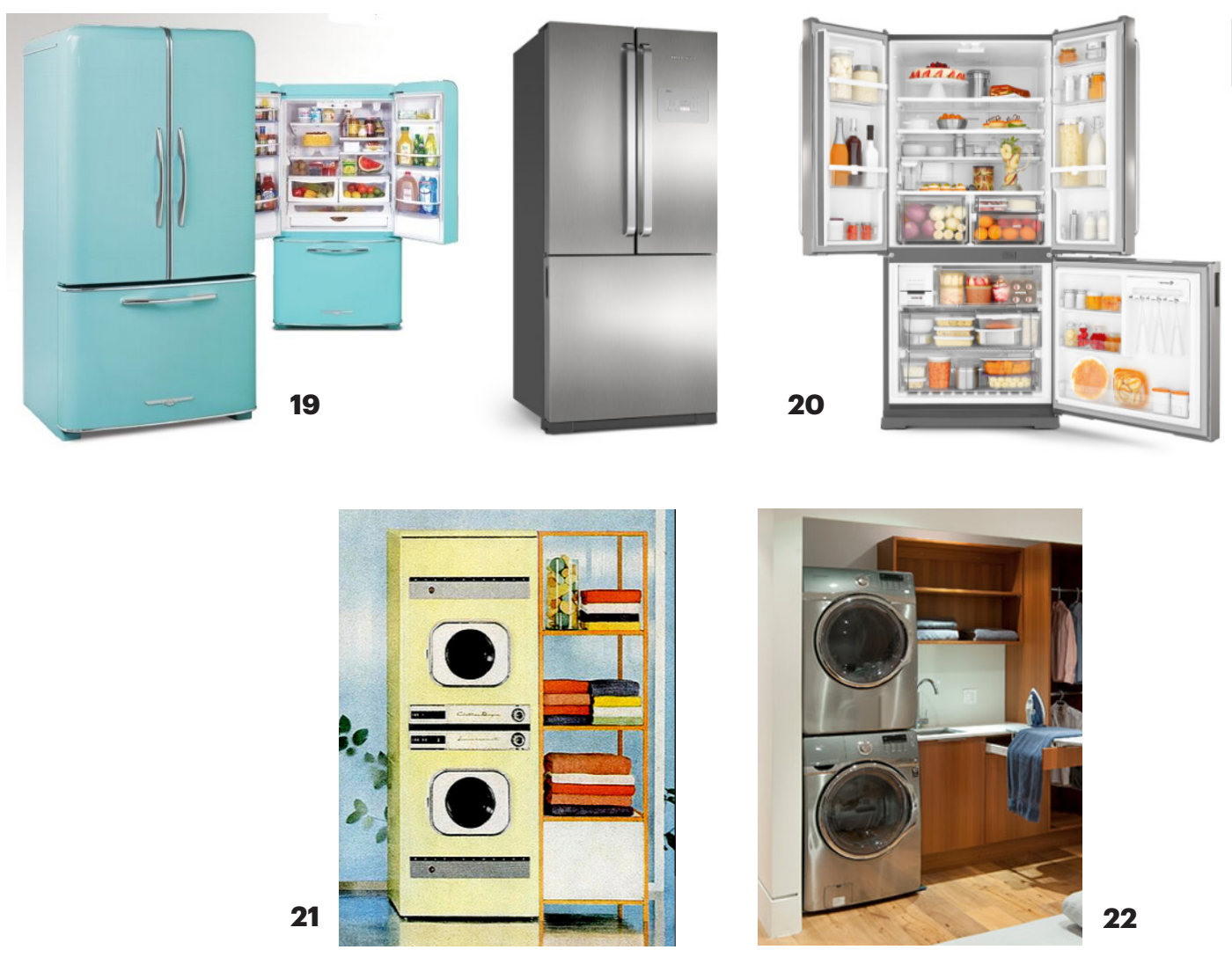

22

Figura 17. Fogão da marca Westinghouse (1960).

(Fonte: www.etsy.com/pt/listing/241341195/1960s-westinghouse-range-ad-retro?ref=market.)

Figura 18. Fogão Brastemp (2016).

(Fonte: http://www.econovia.com.br/produtos/forno-fogao/fogao-brastemp-ative-top-glass-maxi-duplo-forno-inox-bfd4var-4bocas/54483ab6d58fo231860000od.)

Figura 19. Geladeira Northstar (1950).

(Fonte: http://indulgy.com/post/IghIXNcv93/northstar-retro-appliances-ranges-refridgerator.)

Figura 20. Geladeira Brastemp (2016).

(Fonte: http://www.brastemp.com.br/produto/geladeira-brastemp-side-inverse-branca-5401/\#cor=cor-inox.)

Figura 21. Máquina de lavar e de secar da marca Westinghouse (1957).

(Fonte: www.flickr.com/photos/peppermint_kiss_kiss/4339679433/in/photostream.)

Figura 22. Máquina de lavar e de secar (2016).

(Fonte: http://www.tudoconstrucao.com/modelos-de-lavanderias-pequenas-dicas-sugestoes.) 
A repetição dos eletrodomésticos citados e a repetição dos motivos de quebra do celular listados acima sugerem que, apesar dos grandes avanços tecnológicos que podem ser vistos atualmente, o foco do desenvolvimento dos produtos não está na melhoria dos produtos no sentido de eliminar problemas recorrentes.

$\mathrm{Na}$ entrevista com o funcionário da Samsung, a recorrência de quebra das telas dos celulares foi citada também como uma grande queixa dos consumidores. Segundo o entrevistado, no sentido de responder às queixas, foi desenvolvida uma mistura de vidro com outros materiais que se chama "gorilla glass" e que oferece aproximadamente $10 \%$ de resistência a mais para telas. Muitos fabricantes de celular passaram a adotar esse vidro em seus celulares, e inicialmente isso foi também um atrativo para vendas, passando a ser tratado como item padrão depois de um tempo. "Se você olhar isso uns dois ou três anos atrás, você ia ver 'ó, tem gorilla glass', mas hoje já não é mais diferencial" (entrevistado 2). De um certo ponto de vista, este tipo de inovação trouxe um pequeno benefício ao consumidor, ainda que não tenha resolvido uma de suas queixas mais frequentes, e foi utilizado como grande atrativo para as vendas. Uma vez que virou item quase obrigatório em todos os celulares, ele deixou de ser um atrativo, e não houve mais preocupação em melhorar o material ou sua resistência.

O exemplo do vidro do celular relaciona-se ao mesmo tempo com a obsolescência artificial, por ser uma queixa constante dos consumidores sem grandes melhorias ou mudanças no desenho do produto ou nos materiais adotados, e relaciona-se também, por outro lado, com a obsolescência psicológica (tratada a seguir), uma vez que a pequena melhoria que não resolve o problema apresenta-se como uma grande inovação, deixando obsoletos, no exemplo, celulares que não dispõem de gorilla glass.

\subsubsection{Obsolescência psicológica}

Entre as práticas de consumo pesquisadas, itens adquiridos por serem lançamentos têm relação direta com a obsolescência psicológica. Isso porque uma compra realizada por conta de um lançamento está na maior parte das vezes relacionada com uma nova aparência, tecnologia, função ou acessório.

Na pesquisa, verificou-se alta rejeição na aquisição de produtos por serem lançamentos: $90 \%$ dos respondentes afirmam que não compram um produto apenas por essa razão. Porém, entre a minoria que afirmou ser atraída por lançamentos — apenas quatro participantes assinalaram esta alternativa: dois adquiriram um celular, dois adquiriram peças de vestuário - , o principal atrativo é um avanço tecnológico. 
Por outro lado, averiguou-se na pesquisa que a compra de produtos usados é feita pela minoria da população estudada. Apenas 120 respondentes afirmaram comprar produtos usados, sendo carros e eletrodomésticos os produtos mais amplamente adquiridos nesta condição e produtos eletrônicos os menos adquiridos. Entre os produtos listados como última compra realizada ou a que o respondente considerasse importante, apenas 45 afirmaram ter comprado um produto usado.

Segundo pesquisa do Idec e do Market Analysis (2013, p. 60), a obsolescência psicológica é a principal motivação para a substituição de um equipamento entre os brasileiros. Ela caracteriza-se pelo desejo de um equipamento mais atual, mesmo que o consumidor já possua um com a mesma função, e tende a ser mais recorrente, já que grande parte dos produtos acaba não sendo consertada, seja pelo alto valor de seu conserto ou sua impossibilidade, o que acaba por fazer com que sejam trocados.

Conforme visto na revisão da literatura, lançamentos podem ter ligação com a obsolescência psicológica, pois atraem compradores anunciando uma novidade que, na verdade, não traz mudanças efetivas no produto, mas relaciona-se muito mais com modismos ou acessórios desnecessários, conforme define Packard (1965, p. 12):

Entretanto, até que ponto devemos alegrar-nos quando a General Electric introduz no mercado uma torradeira com nove botões, capaz de produzir torradas em nove tonalidades diferentes.

No mesmo sentido, Newton Gama relata que, desde 2005, a Whirpool atrela o número de lançamentos ao bônus dos funcionários. Segundo o entrevistado, a empresa quer com isso sempre aumentar a produtividade, a produção e a qualidade. Ele se diz contrário à essa política da empresa, pois, fazendo assim, qualquer pequena mudança pode ser adotada para classificar como uma inovação ou como um lançamento: "O pessoal fica tentando colecionar essas inovações. Todas as áreas, a engenharia, o pessoal de qualidade, o pessoal do design. E não é isso, você tem que ter qualidade no trabalho".

Segundo Gama, não eram inovações, mas sim pequenas mudanças que aconteciam nos produtos e, como a política do bônus valia para todas as equipes - da qualidade, do design, da engenharia - , elas muitas vezes se sobrepunham, ou seja, se porventura alguma inovação real de design se sobrepusesse a uma inovação de qualidade, ela poderia ser barrada dependendo de como o processo se dava. Segundo Newton, "você gerava algumas inovações que atrapalhavam o cara da qualidade, e isso poderia atrapalhar o bônus dele, então ele não aprovava”. 
Conclusão, as empresas hoje são movidas pelos bônus dos funcionários. Eles estão fazendo as inovações, estão fazendo os melhores produtos, estão fazendo o melhor possível, mas sempre pensando nas pontuações que eles vão ter pra ter o bônus. E eles estão pensando nesse ano só, eles nunca estão pensando no ano seguinte. E não funciona assim. Quando você pensa assim, não vai pra frente. (Newton Gama)

Segundo o entrevistado 2, as alterações nos lançamentos da Samsung são estéticas e funcionais: "você tem alguma coisa mais disruptiva, mas isso é pontual”. Os lançamentos de maior visibilidade acontecem normalmente uma vez por ano, entre março e abril. Segundo o entrevistado, eles concorrem com os lançamentos da Apple, que acontecem entre outubro e novembro. Esse compromisso com as datas de lançamento às vezes apressa processos que precisariam de mais tempo, e, segundo o entrevistado, os acidentes que aconteceram com a linha Galaxy ${ }^{63}$ provavelmente se deram ao fato de o prazo do lançamento ter chegado e os testes todos que deveriam ter sido feitos com os celulares não puderam ser concluídos, causando acidentes.

Segundo ele, a Samsung é uma companhia que investe muito em inovação e se mantém por causa dela.

O modelo S8 tem um microchip com oito nanômetros de espessura, que é uma tecnologia de outro planeta, porque é um processador com uma capacidade gigantesca de processamento e de dados numa espessura que é milésimos de um fio de cabelo. É altíssima tecnologia e está embarcada num produto de massa.

Na Falmec, os lançamentos ocorrem de maneira orgânica, sem periodicidade definida. Elas decorrem normalmente de sugestões do marketing ou de arquitetos que trabalham com os produtos da empresa. Porém, de maneira geral, a cada dois anos é lançado um novo produto principalmente com mudanças estéticas.

Na GM, os carros têm um ciclo de vida que varia de região para região. Para o Brasil e América Latina, esse ciclo é de sete anos, enquanto nos EUA é de cinco. Isso quer dizer que um carro só sofrerá mudanças significativas ou será trocado por outro modelo depois desse ciclo completo, porém, na metade deste tempo, ocorre uma mudança estética grande, chamada de facelift, que apresenta mudanças no farol, na lanterna ou em algumas partes do interior do carro. O nome facelift traz uma associação imediata com a estética, e isso não é por acaso. A ideia principal do facelift é dar uma cara nova para o carro. Segundo o entrevistado "facelift grande é farol novo, lanterna

${ }^{63}$ Problemas com a bateria do modelo S7 faziam com que muitos telefones esquentassem tanto enquanto eram carregados que chegavam a pegar fogo. $O$ telefone não chegou a ser vendido no Brasil. 
nova, grade nova, que dá uma mudada na cara do carro: e isso acontece somente na metade da vida do carro". No meio tempo, podem até ocorrer pequenas mudanças que são integradas ao carro:

\footnotetext{
Geralmente é assim, conseguiu a mesma performance da suspensão, mas com uma suspensão mais barata, então muda isso. Dependendo do que for, acontece até durante a produção, mas, por exemplo, uma vez por ano às vezes muda o padrão de cor do banco, então mudam a cor do interior, acrescenta um cromadinho na porta pra dar uma refrescada. Mas grande mesmo é o facelift. (Entrevistado 3)
}

A obsolescência psicológica baseia-se em fazer com que consumidores se cansem de seus produtos e troque-os antes que se quebrem. Se na época da implementação da obsolescência programada essa prática foi construída, por meio das práticas de consumo listadas anteriormente, atualmente ela faz parte do funcionamento das empresas. Ainda que para algumas empresas entrevistadas não haja uma periodicidade fixa de lançamentos, é como se houvesse uma certa expectativa por meio dos consumidores, a qual a empresa deve corresponder, de sempre renovar seus produtos. Segue válida, nesse sentido, até hoje, a valorização do novo, da novidade conforme apontava Packard em 1965. Também os acessórios como lançamentos foram mencionados nas entrevistas.

Não há uma declaração de que as mudanças sejam em prol da obsolescência programada, contudo ela se encaixa em sua descrição. Na descrição do facelift da GM, nas inovações da Whirlpool ou na rígida periodicidade de lançamentos da Samsung há uma confirmação da diferenciação feita por Whiteley de produtos elaborados de acordo com sua funcionalidade (product-lead) e de acordo com sua venda (market-lead). Entre as empresas estudadas, os produtos voltam-se para o mercado, e não para sua funcionalidade, conforme Packard (1965) e Papanek (1971), havendo assim um certo imediatismo, um pensamento voltado para o próximo ano, conforme Gama também comenta.

\subsubsection{Obsolescência tecnológica}

Itens adquiridos por estarem ultrapassados tecnologicamente relacionam-se com a obsolescência tecnológica, pois uma compra realizada por esta razão é motivada, na maior parte das vezes, pela incapacidade de atualização ou instalar programas nos equipamentos, que muitas vezes ficam ultrapassados na comparação de velocidade ou qualidade de algum acessório.

Foram 34 participantes que assinalaram ter comprado um novo equipamento novo devido ao fato de o anterior ter ficado tecnologicamente ultrapassado, dos quais de- 
zoito adquiram um novo celular; cinco, computadores; sete, eletrodomésticos de grande ou pequeno porte; dois, eletrônicos e dois, categorias variadas.

Nos depoimentos relacionados a celulares, a câmera foi muito citada. Sua definição muda a cada versão, tornando suas antecessoras obsoletas. Dois depoimentos falavam da compra de um videogame, e os depoimentos são a tradução da obsolescência tecnológica: "não era possível mais executar os jogos mais modernos" ou "videogame que tinha ficou ultrapassado. Comprei da última geração". Houve ainda um participante que relatou o que aconteceu com sua impressora: "a impressora anterior era muito frágil, quebrou a bandeja com muita facilidade".

Também entre os 46 respondentes que afirmaram que teriam trocado o aparelho ainda que o anterior não tivesse quebrado, analisando-se detalhadamente os depoimentos, é possível notar que a troca foi feita pelo aparelho anterior estar tecnologicamente ultrapassado ou ter passado por muitos consertos, fazendo com que o respondente desejasse algo novo que não levaria a assistências técnicas.

Entre os comentários compartilhados na rede social, figura um que relata a impossibilidade de continuar usando seu computador por não ser possível atualizar o sistema nem rodar programas novos. Ele também não conseguiu mais trocar peças, pois o computador com mais de cinco anos é classificado como vintage pela Apple.

Fios que se rompem, curto-circuito, botões que deixam de funcionar. Parece um tipo de produto muito frágil, mal projetado ou criado na má-fé mesmo - e, caramba, como é caro. Não tem muito mais "aquele tiozinho bacana do bairro que conserta tudo". Antes, dava certo. Depois, começou a não valer a pena (o conserto era quase $70 \%$ do valor de um novo). E aí o tiozinho começou a fazer corpo mole e dizer que nem tem peça "pra esses produtos montados na China".

Como afirma Slade (2007), pode-se observar que os tipos de obsolescência muitas vezes se misturam na troca de um produto, sendo muitas vezes difícil associar apenas um tipo de obsolescência aos relatos coletados com o questionário. São muitos comentários que juntam razões para uma nova compra: a tela quebrada do celular e o alto custo em arrumá-lo, a câmera que já não era tão boa, o aplicativo que estava lento, uma promoção em muitas parcelas. Ou, então, uma geladeira antiga que não tinha espaço, somada a uma assistência técnica demorada ou ineficiente, a uma promoção e a um modelo mais bonito que se encaixa melhor na casa.

Os motivos somados que levam à troca de produtos mostram uma naturalização das práticas de consumo encontradas na pesquisa e uma consequente naturalização da 
obsolescência programada de maneira geral. Isso vai de encontro com a afirmação de que os brasileiros naturalizam a obsolescência quando aceitam a pouca durabilidade de seus produtos (ECHEGARAY, 2016), exposta na revisão da literatura. Um bom exemplo dessa dificuldade de identificação dos tipos de obsolescência pode ser visto no produto mais citado da pesquisa, conforme veremos a seguir.

\subsubsection{Celular: o produto mais citado}

O celular é um caso emblemático. Ele é o produto mais citado como última compra realizada ou a última considerada importante, assinalado por 153 dos respondentes; é o produto trocado com maior frequência, citado por 256 dos respondentes que preencheram os campos relacionados a trocas frequentes; entre os produtos mais antigos em uso, dez dos participantes afirmam ser o celular; até entre os produtos mais antigos, mas sem uso, o celular foi citado: 25 dos respondentes afirmou ser um celular o produto mais antigo sem uso, em sua maioria guardados pelo fato de o respondente não saber o que fazer com ele ou não saber a maneira correta de descartá-lo.

Houve uma postagem para tratar especificamente sobre aparelhos celulares na sondagem em rede social. A pergunta que se colocou foi: "E o celular? É bem de consumo durável? Quantos você já teve? Com que frequência você troca?”.

Entre os doze participantes que comentaram o post, um atribuiu ao celular a qualidade de bem semidurável. $O$ participante com o menor número de celulares teve cinco aparelhos, e o com o maior número teve onze. Os que comentaram sobre a periodicidade de trocas falaram que ela ocorre em média a cada dois anos, como o participante que diz ter tido oito celulares - segundo ele, "ultimamente tem durado 1,5 ano, mas não troco por estragar, e sim por trocar, e passo o anterior pra frente". Entre os depoimentos se repete o que foi visto anteriormente: consertos onerosos, queda com quebra de tela, dificuldades de atualização de sistema ou lentidão.

7 celulares. $O$ primeiro quebrou, o segundo troquei por um modelo com mais funções, o terceiro foi roubado, o quarto não me adaptei e passei pra frente. O quinto ficou lento e queria uma câmera melhor. O sexto foi trocado pelo atual pois queria uma tela maior, mais espaço, e uma câmera melhor.

Observa-se também uma certa aceitação da impossibilidade de manter o celular por muito tempo:

tenho sempre os mais baratos e descobri a pouco tempo que não adianta querer ficar com o seu celular de estimação, uma hora ele fica velho, o sistema operacional não roda, não adianta vc ter cuidado bem dele durante 2 anos, se apegar... uma hora ele vai ficar velho e vc tem que comprar um novo. 
Nos demais posts da página o celular surgiu de maneira espontânea, e repetiram-se depoimentos sobre a quebra das telas, a velocidade com que a bateria passou a perder carga e ainda os fios danificados e quebradiços dos carregadores de celulares.

a bateria do meu iPhone 5, de 2 anos e meio, já não dura meio período. Ele tem que viver na tomada ou plugado a uma bateria extra. Levei na autorizada para trocar a bateria. Custava $\mathrm{R} \$$ 450,00. Caro, mas melhor que ter que comprar um iPhone novo. Na hora que o senhor abriu o iPhone para trocar a bateria, notou que ela estava "estufada". Ele falou que nesses casos eles não podem retirar a bateria porque há risco de explosão. Se o iPhone tivesse 1 ano, eu teria direito a um novo, sem custos. Mas, passados dois anos, não tenho alternativa a não ser comprar outro!

Segundo o último dado obtido pelo entrevistado da Samsung, a empresa detem aproximadamente metade do mercado brasileiro de celulares que, somando todas as marcas, vende em torno de 55 milhões de celulares novos por ano. A média atual de tempo para a troca dos celulares está entre 15 e 18 meses de acordo com o entrevistado. $\mathrm{Na}$ página do Facebook e no questionário, a média de tempo de uso dos celulares de 24 meses (somando-se o tempo que cada um afirmou ter durado seu celular e dividindo pelo número de pessoas que forneceu esta informação). De acordo com os dados da Anatel, o Brasil terminou o ano de 2016 com 244 milhões de celulares em operação, e até o final de junho de 2017 esse número era de 242,1 milhões.

De acordo com uma pesquisa da Gartner, divulgada no site Tecmundo (PAYÃO, 2016), a empresa que mais vendeu celulares no primeiro semestre de 2016 no mundo todo foi a Samsung: foram 76,7 milhões de smartphones, o que representa uma fatia de mercado de $22,3 \%$. A Apple fica em segundo lugar no ranking das maiores vendedoras de celulares, com $12,9 \%$ do mercado.

A dissertação "Design e flexibilidade: estratégias para o gerenciamento da obsolescência de telefones celulares" (ZACAR, 2010) conclui que o fim da vida de um aparelho é determinado, na maior parte das vezes, por um estrago físico, e sua troca acontece em decorrência da dificuldade ou impossibilidade de utilização de suas funções de uso básicas. Ainda que a pesquisa tenha sete anos e muita coisa tenha mudado desde então, pode-se dizer que esse ainda figura entre os grandes motivos de troca de celulares, como pôde também ser visto na presente pesquisa. Zacar também encontrou um grande número de pessoas que relatou a troca de aparelhos ainda que o equipamento em uso estivesse funcionando de maneira satisfatória. Segundo a pesquisa, apesar de uma aparente contradição, isso decorre do fato de o celular estar também relacionado com a construção de identidades e de relações sociais. "Aspectos subjetivos como afeição, moda, frustração, status, aparência e imagem pessoal revelaram-se extremamente importantes para o processo de obsolescência de telefones celulares" (ZACAR, 2010, p. 158). 
Neste sentido, a pesquisa de Zacar sugere que as mudanças na produção dos telefones celulares não têm como objetivo somente sua durabilidade e longevidade físicas, mas podem adequar-se também ao "contexto sociocultural e às necessidades individuais".

A flexibilização das funções de uso, técnicas e simbólicas dos artefatos seria um caminho altamente recomendável para viabilizar essa adequação, levando em conta as idiossincrasias e a diversidade cultural. Desta forma, seria possível a diversificação dos artefatos sem, porém, incluir elementos supérfluos de diferenciação marginal, voltados apenas para incentivar o consumo repetitivo. (ZACAR, 2010, p. 157)

É interessante também destacar alguns números referentes às estatísticas de uso de celular no Brasil em que mostram o quanto a mobilidade está presente no dia a dia dos brasileiros e como o celular passa, então, a ser um produto com múltiplas funções na vida das pessoas (ESTATÍSTICAS DE USO, 2016).

- No final de 2014 o Brasil já era o sexto mercado mundial de smartphones, superado apenas por China, EUA, Índia, Japão e Rússia.

- No segundo trimestre de 2015, o número de brasileiros que usam o smartphone para acessar a internet ultrapassou a marca de 72 milhões, representando um aumento de $23,5 \%$ em relação ao semestre anterior.

- O número de internautas brasileiros que realizam pagamentos através de seu smartphone dobrou em um ano, passando de $21 \%$ no final de 2014 para $46 \%$ em 2015 (dados de dezembro de 2015).

- $88 \%$ dos brasileiros que possuem smartphone usam o aparelho para trocar mensagens (dado de dezembro de 2015). Embora a percentagem de jovens seja naturalmente mais alta, $70 \%$ dos usuários com mais de 55 anos realizam operações do tipo.

- $26 \%$ dos donos de smartphones pedem comida através de aplicativos, e $20 \%$ os utilizam para chamar táxis ou para comprar ingressos para eventos;

O atual acúmulo de funções do celular, conforme Zacar já apontava em 2010, cria um desafio quanto à sua evolução enquanto produto, pois se por um lado ele soma funções, como Zona Azul, redes sociais - atualmente, existe um aplicativo para quase tudo - , por outro ele é o campeão na geração de lixo eletrônico.

Novamente coloca-se a pergunta feita por Sevcenko (2010), da maneira como lidaremos com as evoluções tecnológicas que acontecerão necessariamente. 
De acordo com matéria do G1 (ARAUJO, 2017), para o celular ficar mais fino e leve, há o acúmulo de funções no vidro, o que acaba por encarecer seu conserto em caso de quebra, já que uma única peça é responsável por inúmeras funções no celular. Porém, como pôde ser observado na pesquisa, este é um dos principais motivos que levaram a troca do equipamento.

Há nesse exemplo uma preocupação do desenvolvimento de produto voltada para o consumidor, mas pouco voltada para uma produção mais racional. Seria possível conseguir o mesmo resultado, porém contemplando a possibilidade de conserto? No mesmo sentido, seria possível desenvolver telefones que pudessem ter seus sistemas atualizados ou que pudessem ter apenas um chip trocado com a chegada de uma evolução tecnológica, fazendo com que as trocas do produto completo fossem reduzidas?

O caso do celular também traz questões levantadas nos itens anteriores da pesquisa: materiais mais baratos para redução de custos e consequente fragilidade dos equipamentos; avanços tecnológicos atraem uma nova compra, ou como foi relatado algumas vezes na pesquisa, chegar a induzir uma nova compra.

Essas características, por um lado, tornam o celular um produto acessível para grande parte da população e trazem grandes facilidades na vida prática, mas, por outro, tornam-no, de certa maneira, um produto descartável.

Tem-se a impressão de que a pesquisa tecnológica é muito avançada no que diz respeito aos celulares, inclusive de acordo com o depoimento reproduzido anteriormente do funcionário da Samsung, mas o foco está no mercado, e não no produto: o pensamento é imediatista e não leva em conta suas consequências, como a geração de lixo.

\subsection{O design dentro das empresas estudadas}

Por meio das entrevistas, procurou-se compreender o papel do design, assim como premissas de desenvolvimento de produto - um dos subproblemas descritos no primeiro capítulo da dissertação - dentro das empresas acessadas: foram três empresas e dois designers independentes. Dado o número reduzido de empresas acessadas, reforça-se que serão reproduzidas a seguir apenas a opinião dos participantes, que não representa o que acontece em outros lugares. Trata-se, portanto, de uma sondagem sem a pretensão de fazer uma afirmação sobre o papel do design hoje dentro das indústrias, mas que pode eventualmente sugerir tendências nesse sentido.

De acordo com os entrevistados, os departamentos de design das empresas acessadas, assim como seu funcionamento, varia muito em cada uma delas, como veremos a seguir. 
A Samsung possui departamento de desenvolvimento de produtos apenas na sua central sul-coreana, e mesmo as eventuais adaptações para o mercado local são feitas na matriz. No Brasil, existe um departamento de design gráfico relacionado ao marketing.

A Falmec possui um designer de produtos na criação (que é também um dos diretores da empresa) que está em contato constante com uma pessoa mais técnica que fica na fábrica. $\mathrm{O}$ desenho dos produtos (principalmente coifas, mas também cooktops e fornos elétricos) é feito em parceria entre os dois. Para o entrevistado da Falmec, "a questão do design é prioritária", pois segundo ele "a funcionalidade é uma questão fundamental, então, claro, investimos na funcionalidade do produto, mas o que vai diferenciá-lo no mercado é a questão da valorização do design".

A GM possuía uma grande equipe de design, e muitos carros foram desenhados aqui entre 1994 e 2016, como o Ônix, Cobalt e Spin. O departamento foi reduzido a partir de 2016, e atualmente existe apenas uma pequena equipe de designers responsável por fazer as adaptações necessárias para o mercado brasileiro, que se relacionam principalmente com questões de legislação e também custos: o carro para ser vendido no Brasil tem que ser mais barato do que em outros mercados.

Na GM não há uma hierarquia de departamentos: design e engenharia trabalham lado a lado e não são submetidas à área do marketing. Segundo o entrevistado, eles usam um conceito intitulado "conflito construtivo", que estimula um embate que gera uma discussão a qual permite chegar na melhor solução. As premissas de design nascem de pesquisas de mercado e dos competidores, e há uma classificação interna entre "o que esse carro tem que ter, o que é desejável que tenha e o que vai fazer ele ser um vencedor no segmento dele". Há também análises do modelo anterior, e tanto design quanto engenharia, assim como marketing e vendas, participam de todas essas definições iniciais do carro, que o entrevistado chama de "critérios".

Sobre um eventual ciclo completo dos carros, como o exemplo da BMW visto anteriormente, segundo o entrevistado, isso acontece na Europa porque lá o carro tem que ter uma porcentagem de reciclagem mas alta do que aqui, e "as empresas fazem isso há mais de 30, 40 anos”. Na sua opinião, a lei no Brasil estimula muito pouco uma produção mais sustentável: “tem as ações e os materiais recicláveis pra você usar, coisas que são ecologicamente amigas, mas esse ciclo de voltar para a fábrica pra você ter uma porcentagem muito alta ou totalmente reciclável é muito pouco falado".

Vale destacar que a GM foi protagonista no grande aumento do mercado de carros, como foi visto no capítulo 2 desta dissertação. Atualmente, a empresa tem investido 
em pesquisas de veículos inteligentes e no desenvolvimento de sistemas de compartilhamento de carros, ou car sharing, que consiste numa frota de veículos que pode ser alugada por hora. No projeto piloto que começou a ser implementado em março de 2016 em São Caetano do Sul, havia sete unidades disponíveis que poderiam ser retiradas e devolvidas no mesmo local. O programa prevê para uma segunda etapa de implementação que a retirada e entrega dos veículos aconteça em mais pontos da cidade, nos mesmos moldes da locação de bicicletas adotada nas grandes cidades brasileiras, como as bicicletas patrocinadas pelo banco Itaú, e finalmente adotar um sistema que, juntamente com um aplicativo de celular, disponibilize carros em qualquer parte da cidade, ou seja, você pega o carro mais próximo de você, estaciona onde precisar. $\mathrm{O}$ controle do horário de retirada e devolução do carro é feito por meio de um aplicativo de celular, que também é capaz de trancar e destrancar o carro, que permanece sempre com a chave (SILVA, 2016; GM LANÇA, 2016). Nas palavras do presidente da GM, Dan Ammann, “achamos que o compartilhamento de transportes é interessante, e pensamos que os veículos autônomos são interessantes, e acreditamos que podemos unir os dois" (CARROS AUTÔNOMOS, 2016).

Newton Gama relatou e comparou sua trajetória nos dois momentos: dentro da Whirpool, entre 1979 e 2005, e como consultor da Esmaltec, na década de 2010. No primeiro momento, fundou um departamento de design que contribuiu para a Consul tornar-se uma das líderes de mercado na década de 1980. Cabe observar que sua trajetória se assemelha muito ao desenvolvimento da profissão de designer descrito na revisão da literatura. Assim que entrou na Consul, o departamento de design estava a serviço do styling e das vendas, submetido ao departamento de engenharia. A partir da década de 1990, o design foi valorizado dentro da Consul e ganhou autonomia, podendo sugerir modificações nos produtos com um foco maior nos consumidores. Essas mudanças não eram tão voltadas à estética, mas também a melhorias funcionais dos produtos. Nesse momento, design e engenharia passaram a trabalhar sem diferenças hierárquicas, juntamente com a equipe de marketing. Nos últimos anos dentro da Whirlpool, o design perde espaço novamente, ficando submisso desta vez ao marketing. Porém, se num primeiro momento ele estava submisso ao departamento de engenharia, atualmente ele está a serviço das vendas.

Você perguntou do papel do design dentro das empresas, deixa eu responder, acho que isso é importante falar. As empresas, não só no Brasil, mas também na Itália, eu tenho contato com o pessoal que trabalha lá e nos EUA. O valor do design funciona conforme a importância do líder do design. Se ele não consegue vender o peixe lá na diretoria, a área de design vira uma areazinha de decoração final do produto. (Newton Gama) 
Na opinião de Gama, a influência do departamento de design dentro das empresas tem muito a ver com a pessoa que ocupa um cargo de liderança no departamento. Porém, na sua opinião, se no lugar de uma parceria entre departamentos há uma hierarquia, ela só faz prejudicar o desenvolvimento de produtos.

Após sua saída Whirlpool, Gama trabalhou como consultor de design em algumas empresas, montando departamentos inteiros em algumas delas, como foi o caso da Esmaltec. Segundo o entrevistado, dentro da Whirlpool, o foco era o consumidor, enquanto na Esmaltec o foco era o revendedor. Assim, premissas de design e de lançamentos são decididas entre revendedor e comercial da empresa. "Quando eu trabalhava na grande empresa a gente fazia produto para o consumidor, agora, nessas outras empresas menores/médias, as empresas trabalham pro revendedor, então vale o que, por exemplo, as Casas Bahia quer." No caso da Esmaltec, participam das decisões o presidente da empresa e o diretor comercial, “e o designer não é convidado pra essa reunião, depois só chega pra ele a ordem das coisas que tem que ser modificadas ainda que ele ache ruim e ache que não vai vender". Os pedidos, que passam a ser as premissas para novos desenhos, partem do revendedor, que observa suas vendas.

\footnotetext{
O revendedor ele não pensa que a marca tem que carregar qualidade, ele tem um compromisso, ele quer é rodar mesmo. Se você for atrás do revendedor, aí você faz aquele produto que vai quebrar daqui a dez meses, o revendedor não quer nem saber, agora a gente que tem a marca pra defender o valor da marca não faz o puxador que quebra daqui dois anos porque isso aí vai dar uma epidemia depois. Você vende e aí depois são centenas de reclamações todo mês, e isso dá muito prejuízo. Eu vivi esses dois mundos, na Whirlpool a gente via o que o consumidor quer, não o revendedor. (Newton Gama)
}

Tanto na GM como na Multibrás, segundo os entrevistados, questões de sustentabilidade são muito fortes na política da empresa. Na GM, há uma cobrança muito grande da diretoria da empresa nesse sentido, como por exemplo: “o objetivo de ter a fábrica zero resíduo ou então o resíduo que é produzido ser reduzido ao máximo. Esse pensamento é bem forte". Dentro da Multibrás havia uma pessoa apenas para cuidar disso na etapa de desenvolvimento de produto. Porém, sobre a Política Nacional de Resíduos Sólidos, os entrevistados afirmam que ela influencia a geração e o tratamento dos resíduos na fabricação dos produtos, mas não modifica um sistema de recebimento dos produtos descartados como propõe a logística reversa, por exemplo. Na opinião dos entrevistados da GM e da Samsung, uma mudança maior no projeto só deve acontecer se houver uma mudança na legislação.

Para o designer Marcos Batista, os percursos das empresas que têm escala de produção e trabalham com bens de consumo são muito diferentes, assim como a atuação 
do design dentro delas. Segundo seu relato, existem departamentos de design que trabalham apenas na função ou na estética dos produtos, mas existem também departamentos que atuam também com pesquisas. As empresas podem possuir departamentos internos ou externos. Caso sejam externos, elas podem optar por contratá-los apenas para o desenvolvimento de um produto específico ou "para participar da inteligência ou da inovação da empresa".

Então, se você pega, por exemplo, a Electrolux e a Brastemp, eles têm uma área de design interna que atua de uma maneira estratégica, no sentido de trabalhar realmente nas diretrizes da empresa. Então as diretrizes não são apenas focadas na engenharia, marketing e vendas. Está focado também em design agora; e design de uma maneira bem mais ampla do que na década passada. (Marcos Batista)

Para Batista, o design começa como um departamento de estilo, submisso ao departamento de engenharia e mais ligado à questões estéticas; vai ganhando força e participando mais dos processos até que as vendas passam a ser mais importantes e o design volta a ficar sujeito ao marketing; até que o marketing "para no tempo", que segundo ele é o estágio em que estamos, no qual o marketing está se reinventado. Na sua opinião, quando o design foi para o marketing, "ele não tinha linguagem nem vida própria, trabalhava como um bracinho da engenharia. Só a partir de 2006 que o design começou a ganhar um papel de destaque, pois passou a mudar a maneira de enxergar valores e entender problemas em profundidade". Ele cita como exemplo de empresas que mostraram a importância do design a Apple e a Procter \& Gamble.

Na sua trajetória profissional, Marcos Batista começou a trabalhar na Continental em 1991,

[...] época em que o designer só trabalhava forma-função, ou seja, o grande interesse da indústria era o funcionamento de um produto, o designer era o cara que realmente trabalhava num apelo estético diante dos recursos que tinham na época, e a gente desenvolvia o melhor da estética diante daquele recurso, mas o interessante para a empresa nesse momento era a qualidade e o funcionamento.

O design evolui e passa a fazer parte da estratégia de marketing quando começa a acontecer uma abertura de mercado, quando a internet se estabelece e quando são instituídos novos modelos de consumo. Isso acontece para que o design se aproxime mais do consumidor e possa entender mais sobre os valores da marca - essa época coincide com o surgimento também do branding - e sobre as ferramentas de consumo, como os pontos de vendas.

Segundo seu relato, essa evolução veio do mundo digital: 
As pessoas começaram a consumir diferente, o seu posicionamento sobre os produtos mudou, e esse universo de branding e design estratégico nasceu efetivamente porque as empresas precisavam construir seus produtos e serviços em cima de um propósito, em cima de uma causa, ou seja, não era mais você desenvolver produto e colocar à venda e buscar uma demanda, era o contrário, descobrir uma demanda por problemas não resolvidos pra depois gerar produtos e serviços, então mudou a ordem.

Em suas palestras, Batista fala muito do mundo em transformação em que vivemos e dos novos modelos de negócio que começam a surgir. Na sua opinião, o design tem um papel fundamental como ferramenta de inovação na identificação e na solução de problemas e não pode, portanto, ficar restrito a um modelo de negócio que o trate somente como um departamento a serviço do marketing, das vendas ou da engenharia. Caso contrário, a empresa corre grande risco de começar a perder clientes e vendas.

Por outro lado, segundo Marcos Batista, existe a preocupação da indústria de se reinventar quanto a seus processos no que diz respeito ao desenvolvimento de produtos de larga escala.

Por exemplo, existe a economia circular e o que as empresas estão buscando dentro da indústria 4.o. Dentro da economia circular tem um papel fundamental de conexão com o design. Esse é um ponto que não parte apenas da inovação de produto, mas de uma inovação de processo e de modelo de negócio, então hoje eu não vejo mais uma coisa separada da outra como existia no passado o sistema produto, processo e modelo de negócio.

Ainda existe muita resistência dentro das empresas em adotar o design como uma estratégia, e não apenas um departamento submisso a outro: "Eu falo de design no Brasil promovendo-o como inteligência, como estratégia e eu sei o quanto é difícil e o quanto existe uma resistência. E o quanto as pessoas não sabem o que é design direito ainda". Por outro lado, de acordo com sua experiência em grandes empresas, ele também identifica a vontade das indústrias de se reinventar. Nesse sentido, legislações ou pressões de consumidores mais conscientes ajudariam num processo de mudança na maneira como os produtos industriais são produzidos atualmente.

O departamento de design dentro das empresas em que atuam os entrevistados funciona de uma maneira diferente em cada uma delas, impossibilitando qualquer afirmação quanto ao papel do design dentro das empresas de uma maneira geral no Brasil ou tampouco sua relação com a obsolescência programada.

Pode-se notar, contudo, que, com exceção da GM, as empresas estudadas têm seus departamentos de design mais voltados para questões estéticas, como no caso da Falmec, e mais para questões tecnológicas e mercadológicas, no caso da Samsung (isso 


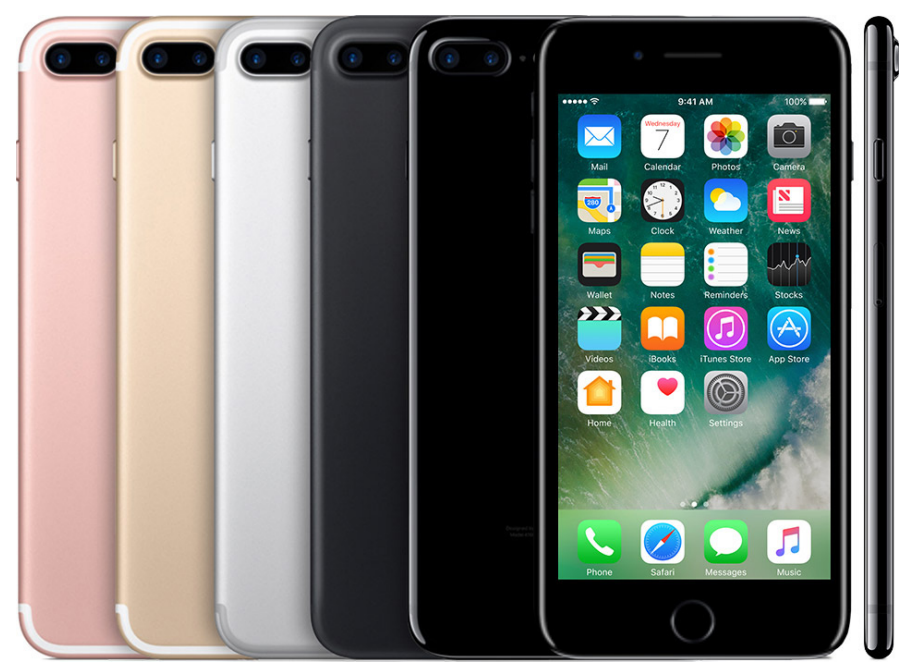

23

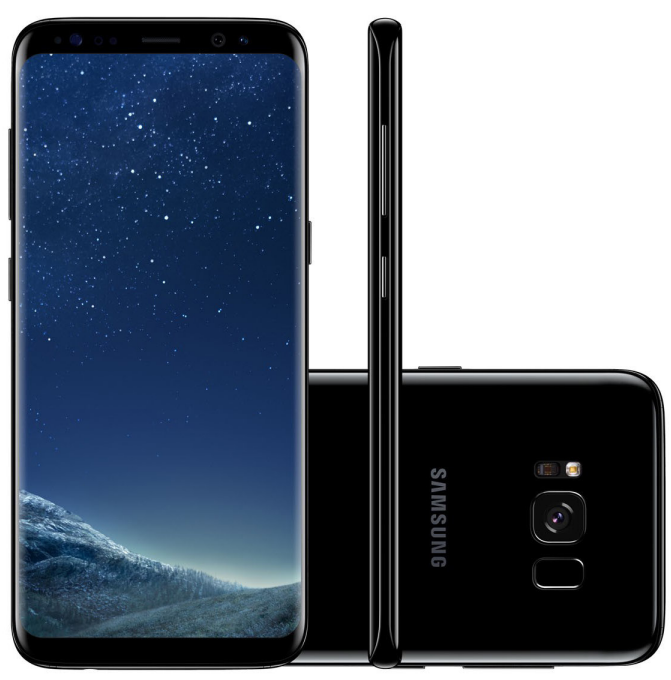

24

Figura 23. Celular Apple (iphone $7 \mathrm{~S}$ Plus). (Fonte: http://www.infomoney.com.br/minhas-financas/gadgets/noticia/6000081/anos-desde-primeiro-iphone-confira-evolucao-smartphone)

Figura 24. Celular Samsung Galaxy S8. (Fonte: https://www.magazineluiza.com.br/smartphone-samsung-galaxy-s864gb-preto-dual-chip-4g-cam.-12mp-selfie-8mp-tela-5.8-quad-hd/p/2175625/te/gas8/.)

pode ser visto nas Figuras 23 e 24, que compara o celular da Apple e da Samsung - as diferenças são mínimas). Nestas empresas, não foi possível identificar a atuação do design de maneira mais sistêmica como pôde ser visto na GM ou no relato de Newton Gama no tempo em que trabalhava na Consul.

Dessa maneira, as práticas das empresas entrevistadas não evidenciam nenhum envolvimento com a obsolescência programada, mas, da mesma maneira que as práticas de consumo apontam para sua naturalização na sociedade, as premissas de projeto, assim como um design menos influente dentro das empresas indica a adoção de um modelo voltado para o mercado. Os produtos são muitas vezes feitos para serem baratos, não com o intuito de quebrar, mas com o de vender. Neste sentido, há também uma percepção do "crescimentismo", apontado por Packard (1965) e por De Masi (RODA VIVA, 2013).

Pode-se observar que os produtos são muitas vezes modificados de acordo com sugestões - ou até mesmo exigências — de seus revendedores, o que faz com que se perca um pensamento mais amplo do produto e se foque em algo imediatista, como relatado por Gama, no caso da Esmaltec. Assim, pode-se dizer também que o design fica muitas vezes privado de exercer todas as funções de que é capaz, limitando sua ação às etapas finais de fabricação mais voltadas à estética, muito semelhante ao que propunha Lippincott na década de 1940. 
Ao serem perguntados sobre a lei de resíduos sólidos, os entrevistados referem-se à sua influência sempre na parte inicial da produção, não tocando em estratégias como logística reversa. De acordo com o entrevistado da GM e o da Samsung, isso deveria ser conversado dentro das empresas, mas não acontece.

Também nas entrevistas, a associação de materiais com custos e uma oposição entre materiais e tecnologia pode ser identificado. No caso da GM, materiais menos resistentes em muitos casos colaboram para uma segurança maior dos passageiros, enquanto na Samsung materiais mais frágeis tornam os produtos mais baratos e menos duráveis.

\subsection{Conhecimento sobre o fenômeno da obsolescência programada}

No questionário, verificou-se amplo conhecimento do termo "obsolescência programada”, assim como grande incômodo do fenômeno pela população estudada. Entre os respondentes, ela é associada ao setor financeiro, que visaria o lucro, como mostra o Gráfico 9. O conhecimento do termo “obsolescência programada” está associado a:

- Gênero. Homens aparentam ter um domínio maior sobre o termo obsolescência programada do que mulheres.

- Forma de pagamento. Entre os respondentes que assinalaram fazer suas compras com pagamentos à vista, o conhecimento do termo é proporcionalmente maior.

- Faixa etária. O termo obsolescência programada é mais conhecido entre as faixas mais jovens de participantes, sobretudo dos 26 a 45 anos.

- Designers. Dos respondentes da pesquisa, 38 se declaram designers, ${ }^{64}$ e o conhecimento prévio do termo obsolescência programada mostrou-se associado a isso, ou seja, proporcionalmente, designers têm maiores chances de conhecê-lo.

Como pode ser visto no Gráfico 9, a maioria das pessoas associa a prática da obsolescência programada ao setor financeiro das empresas.

${ }^{64}$ Foram considerados designers todos aqueles que afirmaram ser designers gráficos, professores de design ou apenas designers. 


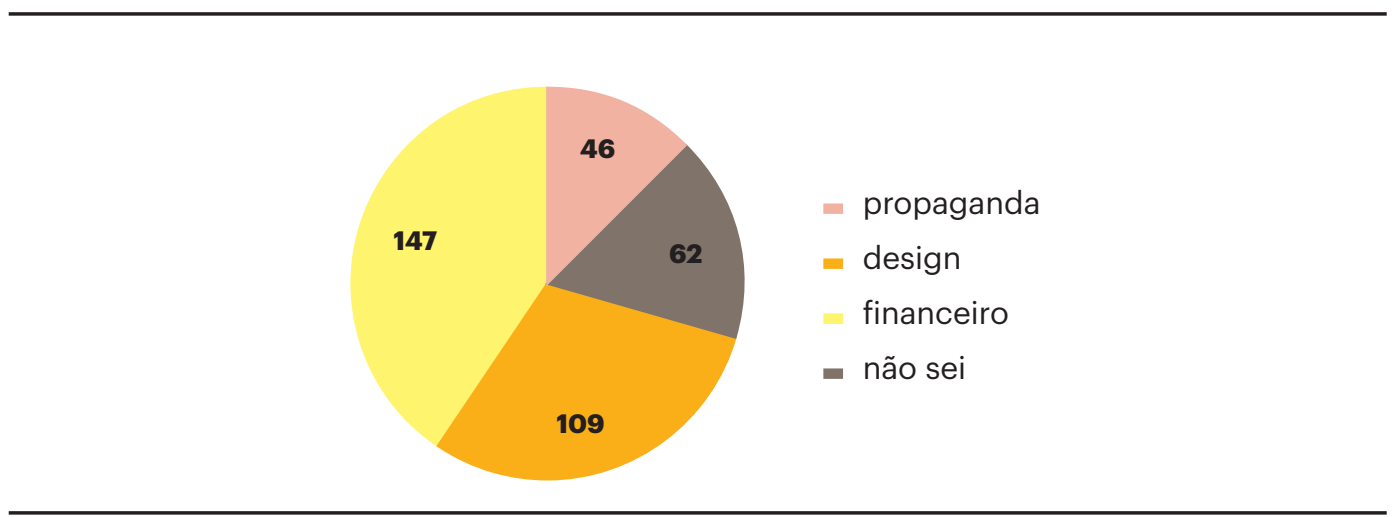

Fonte: elaborado por Eduardo Lazzari, a partir de dados do questionário, 2017.

Entre os 147 participantes que atribuem o fenômeno ao departamento financeiro, 54 usaram a palavra "lucro" em seus depoimentos, e suas justificativas versam sobre o fato de o objetivo principal da empresa ser o de gerar lucros. Na opinião dos respondentes, o departamento financeiro é o que detém conhecimentos de pesquisa de mercado e dos números que farão com que a empresa continue aumentando suas vendas, como pode ser lido em um dos comentários:

Porque é ele que acaba determinando o ciclo necessário para que a venda e lucro da empresa funcione com cada nova produção destes produtos, influenciando no design dos produtos e utilizando o departamento de propaganda como instrumento de persuasão na compra de novos.

Embora nenhuma dos entrevistados concorde ou afirme trabalhar com o conceito de obsolescência programada, é possível traçar um paralelo entre as opiniões dos participantes que atribuem ao departamento de vendas o fenômeno estudado e as entrevistas realizadas. Como foi visto no item anterior, Whirlpool, Esmaltec e Falmec desenvolvem seus produtos de acordo também com as demandas de seus revendedores atualmente.

Na opinião do entrevistado da Falmec, também “o design não tem muita relação com a obsolescência programada, pois ela é "um fenômeno mais comercial".

O segundo departamento mais assinalado pelos participantes da pesquisa foi o departamento de design, assinalado por 109 dos participantes. De maneira geral, pode-se perceber que essa identificação se dá por atribuir-se ao design a função de projetar e planejar um produto, incluído neste processo seu tempo de vida útil, ainda que alguns participantes façam ressalvas quanto à sua autonomia, complementando que os projetos vêm com premissas estabelecidas de áreas superiores ou da direção da empresa, 
como pôde ser lido em um depoimento: "Acredito que seja uma estratégia financeira que seja imposta no design... Então os produtos são feitos intencionalmente para durar menos do que poderiam de fato"; ou em outro que alega perceber uma "necessidade em inovar os produtos, especialmente no design, para fazer com que o modelo anterior pareça ultrapassado. Muitas vezes estas inovações no design não são feitas para facilitar o uso, mas apenas para parecer mais moderno".

Nesse sentido, estabelece-se relação com a ideia proposta por Forty (2007), de que todos os objetos são desenhados. Seja por questões de materiais impostos ou por questões estéticas, a atribuição do fenômeno com o design estabelece essa relação.

O departamento de propaganda foi associado à obsolescência programada por 46 participantes da pesquisa. Em sua maioria, as justificativas falam sobre ela ser a vitrine do produto e ao mesmo tempo a responsável por aumentar as vendas. Também aqui se fazem ressalvas à propaganda não trabalhar sozinha, mas junto com outros departamentos ou sob uma política geral da empresa, como se pode ler no depoimento a seguir: "porque ele cria ideias de necessidade de mudança dos produtos, mas é relacionado a outros departamentos".

Entre os respondentes, 62 afirmaram não saber a que departamento das empresas a obsolescência relaciona-se, enquanto oitenta preencheram o campo aberto disponível nesta pergunta. Para estes participantes, o fenômeno relaciona-se não somente com um departamento da empresa, mas como um pensamento que rege a empresa como um todo e que envolve todos os setores, e entre eles a palavra "lucro" foi mencionada por dez dos participantes, como pôde ser lido em alguns comentários: "porque esse aspecto não se encontra isolado no design, ou na promoção, ou no lucro, é anterior aos departamentos e direciona o trabalho de todos" ou "acredito que seja uma estratégia de negócio e não uma ação individualizada de um só departamento". No mesmo sentido, o entrevistado da Falmec afirma não trabalhar com o conceito de obsolescência programada, mas identifica isso em outras empresas. Ele acredita que, se uma empresa trabalha com esse conceito, deve envolver todos os setores.

Para o entrevistado da GM, "essa parte de você projetar pra ser obsoleto na minha opinião é um pouco mito. Porque hoje você usa materiais mais frágeis, mais fáceis de ser manufaturados. A premissa básica do carro é te levar de A para B, nem que seja pra você se exibir. Mas se o carro quebra na rua, você não vai ficar feliz”. Para ele, estão sempre sendo pesquisadas novas maneiras de fazer com que vendas e performance do carro melhorem ao mesmo tempo. "Acho que é mais pelo lado de atrair com coisas boas de qualidade do que uma coisa que o cara tenha que trocar porque ele vai exau- 
rir.” Assim, os lançamentos têm sempre mais de um atrativo. "Então, além de ter o farol novo, a lanterna nova, o para-choque novo, ele tem um motor novo que é muito mais econômico."

\section{Para Newton Gama:}

Tinha uma época que as pessoas diziam que a gente fazia obsolescência programada porque os produtos não duravam, eram todos fraquinhos. "A geladeira que a minha mãe tinha dos anos 50, eu podia dar um chute na porta que não entortava, agora eu encosto e ela já entorta.” E eu dizia não, mas isso não é por causa da obsolescência, isso é por causa do preço. Aquela geladeira dos anos 1950 ela custava o preço de um carro, o preço que um carro mil hoje custa. Quando uma família ia comprar uma geladeira nos anos 1950 era como se uma família hoje fosse comprar um carro mil, é essa proporção. Então naquele tempo aquele produto era um muito robusto, até porque naquela época as tecnologias aplicadas necessitavam que ele fosse robusto. $O$ produto foi sendo racionalizado e sendo modernizado nos materiais. Ele foi ficando mais leve e mais barato. Agora, ele dura um tempão também. Ele não dura talvez vinte anos, ele dura doze, quinze, que já é muito bom. [...] Eu trabalho há muitos anos em design, nunca esteve na mesa essa premissa de "vamos colocar esse tecido aqui que vai durar menos e na última prestação vai rasgar e aí ele vai ter que comprar outro". o que existe é "precisamos ter um produto mais barato".

A distribuição das respostas do questionário relaciona-se, de certa maneira, com as respostas sobre o departamento de design dentro das empresas, pois ele revela também qual departamento define as premissas de projeto dentro das empresas. De acordo com os relatos de Newton Gama e de Marcos Batista o departamento de design pode, muitas vezes, estar submisso ao de marketing, por exemplo. As premissas de design, neste caso, seriam definidas por este departamento influenciando de certa maneira sua aparência final.

A obsolescência programada é algo que incomoda 414 dos participantes da pesquisa. Durabilidade e qualidade foram palavras muito citadas (80 e 27 vezes, respectivamente) nos 358 depoimentos do campo aberto reservado ao que poderia ser diferente ou que poderia mudar em relação ao fenômeno estudado. Muitos participantes manifestaram o desejo de que seus produtos durem mais ou que seja possível consertá-los de maneira menos onerosa e mais simples, como se lê a seguir: "A durabilidade representaria menos lixo e menos gastos". Ou, então, "ao invés da lógica da quantidade, a qualidade deveria se manter".

É totalmente absurdo que isso seja aceito, amplamente praticado e ninguém sequer fale no assunto. Se um produto pode durar mais, não tem sentido que tenha sua duração reduzida por interesses de mercado. 
Alguns depoimentos tratam das consequências ambientais da obsolescência programada, dos quais destacam-se:

Porque para além das questões financeiras — perdemos dinheiro com isso - , enquanto as empresas lucram mais, temos as questões ambientais. $O$ mundo consumista não pode ser mantido por muito tempo com os recursos naturais de que dispomos nesse planeta.

Porque em primeiro lugar faz as pessoas gastarem mais seus dinheiros e em segundo, temos que pensar no planeta... esse lixo todo aonde vai parar? O planeta é aqui, não existe "vou jogar fora"... o "fora" é aqui mesmo!

Porque acabamos consumindo demais, gerando muito lixo. Não sei qual a solução para este problema... A grande indústria precisaria se remodelar.

Entre as sugestões do que poderia ser diferente, destacam-se algumas que propõem um investimento maior nos serviços, e não nos produtos, como se lê a seguir:

Transformar produtos em serviços.

Porque é oposto da sustentabilidade. Tem de mudar na direção de as empresas ganharem dinheiro oferecendo serviços, não produtos.

São apontadas também como possibilidades para lidar com o avanço rápido da tecnologia, a atualização de software sem que seja necessário trocar todo o equipamento ou o aumento do ciclo dos produtos, como nos exemplos a seguir:

Possibilidade de fazer upgrade sem a necessidade de trocar o produto completo.

Me incomoda porque me sinto enganada. Não acredito que no contexto atual as empresas abririam mão de seus lucros. Acho que uma saída possível vai no sentido de encontrar um ciclo mais inteligente. Receber de volta partes dos produtos e reutilizá-los, algo assim, não sei.

Um sistema de troca por um novo produto, mesmo que da mesma marca, mas com baixo preço para troca, poderia ser uma solução viável. Aconteceria a reutilização de peças, a fidelidade do consumidor, e a obsolescência, mesmo que programada, haveria um descarte mais consciente.

Alguns participantes apontaram a necessidade de conscientização dos consumidores e uma regulamentação maior dos produtos, seja no sentido de eles conterem informações a respeito de sua durabilidade ou fornecimento de peças, seja em um estímulo fiscal para consertos, tudo no sentido de não estimular um consumo repetitivo.

Aumento de tempo de garantia mínima legal para cada produto. Padronização de componentes de produtos para auxiliar na manutenção e substituição sem depender tanto da marca ou modelo.

O Estado deveria acompanhar de perto para inibir essa prática. 
E, no mesmo sentido da conscientização dos consumidores, alguns comentaram a necessidade de se rever o modelo consumista vigente:

Consumismo demais. Devemos usar o que temos e não comprar tanto.

Me incomoda não só pela maneira como aumenta o consumismo e consequentemente doenças psicológicas ligadas a ele, mas também pelo grande impacto ambiental que esse consumo gera. Acredito que poderiam ser adotadas práticas de incentivo para reutilização e conserto de objetos, ao invés de seu descarte.

É um modelo que negligencia tanto os profissionais quanto os consumidores/usuários. Novos modelos são necessários, novas posturas e ações.

É interessante destacar também que, nos pré-testes realizados, ${ }^{65}$ três dos quatro entrevistados não conhecia o termo obsolescência programada, porém, imediatamente após a leitura de sua definição, identificaram a prática em sua vida cotidiana e mostraram-se bastante interessados sobre o assunto lembrando-se e relatando episódios similares aos produtos perguntados anteriormente, acabando por associar experiências com outros produtos e o fenômeno estudado. Isso indica, portanto, que a prática da obsolescência programada está presente e naturalizada no cotidiano das pessoas, ainda que não saibam seu nome.

Os comentários reproduzidos do questionário mostram um interesse dos respondentes em uma mudança na maneira de consumir e utilizar produtos, questionando a sociedade de consumidores descritas - e criticadas — por Bauman (2008, p. 111), que afirma que a "a 'síndrome consumista' envolve velocidade, excesso e desperdício". No mesmo sentido, a pesquisa do Instituto Akatu, realizada em 2012, sobre a percepção do consumidor brasileiro, em sua oitava edição apresenta duas conclusões:

Parece estar começando a ganhar força uma contranarrativa do consumismo que, de dentro do discurso e da lógica consumista em vigor, tenta se conectar à emergência de aspirações que apontam como objetivos principais a saúde e o desfrute de uma vida com qualidade. [...] Vale ressaltar que a nova classe média emergente representa um adicional de mercado que serve como oportunidade para a mudança do modelo de consumo, com menor risco para as empresas. (INSTITUTO AKATU, 2013, p. 12)

Para Marcos Batista, não vivemos apenas em uma era de mudanças, mas estamos vivendo uma mudança de era. E, nesta mudança, há uma valorização do acesso no lu-

\footnotetext{
${ }^{65}$ Foram realizados quatro pré-testes, nos quais a pesquisadora aplicou o questionário presencialmente a dois homens e duas mulheres com variadas idades e rendas declaradas; e quatro pré-testes virtuais, com quatro mulheres de variadas idades e rendas declaradas (as pessoas responderam às perguntas por e-mail e, a seguir, fizeram comentários e sugestões).
} 
gar da posse de produtos. Ele cita em suas palestras o exemplo de uma furadeira, desenvolvida para durar mil horas, mas que no uso doméstico é utilizada em média doze minutos. Ele pergunta: “o que você precisa? Da furadeira ou de um furo?”. O fato de precisarmos do furo, e não da furadeira, mostra como a mudança que estamos vivendo interfere na maneira como os artefatos são produzidos. O exemplo do investimento que a GM está fazendo em uma empresa de compartilhamento de veículos é um sinal de que deve haver uma mudança na produção dos artefatos que vai no sentido do compartilhamento de bens, e não mais de posse, um caminho que vai ao encontro das soluções para a obsolescência programada citadas por Papanek (1971) e por Packard (1965).

Por meio do questionário, é possível inferir a existência da obsolescência programada pela percepção dos participantes da pesquisa e também pelas premissas de projeto averiguadas nas entrevistas. Pode-se afirmar que ela é uma prática bastante naturalizada, porém com diferentes tipos de aceitação. Pode-se dizer também que os tipos de obsolescência se misturam, o que de certa maneira ajuda a difundi-la, pois torna-a menos evidente. Isso faz com que os produtos não precisem, necessariamente, ser feitos para quebrar, pois sua lógica já está naturalizada no comportamento da indústria e dos consumidores. 



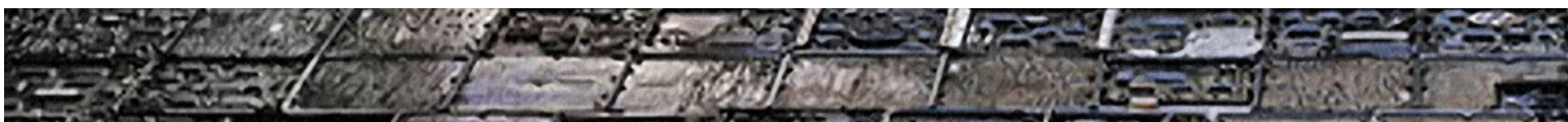

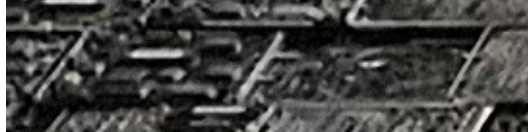

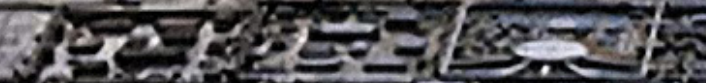

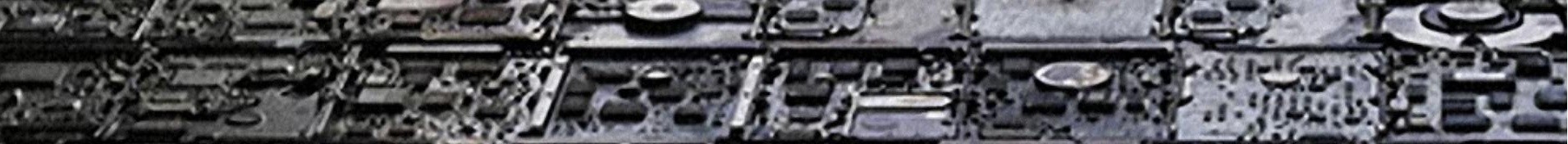

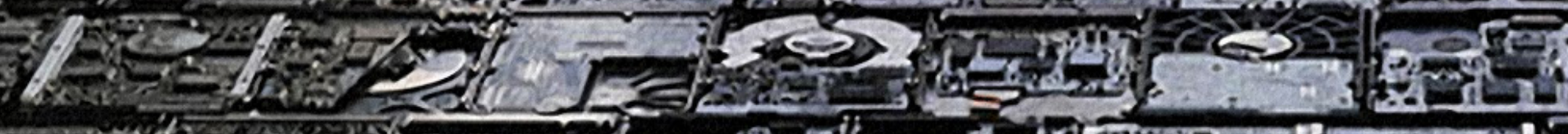

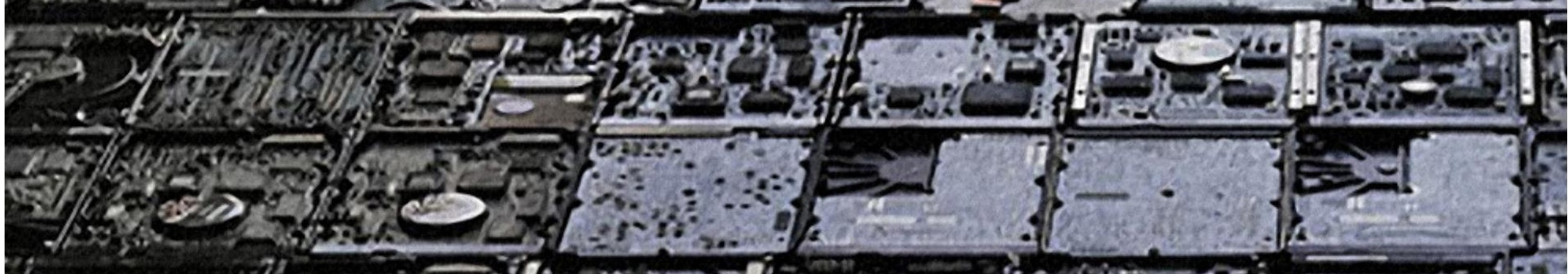
-

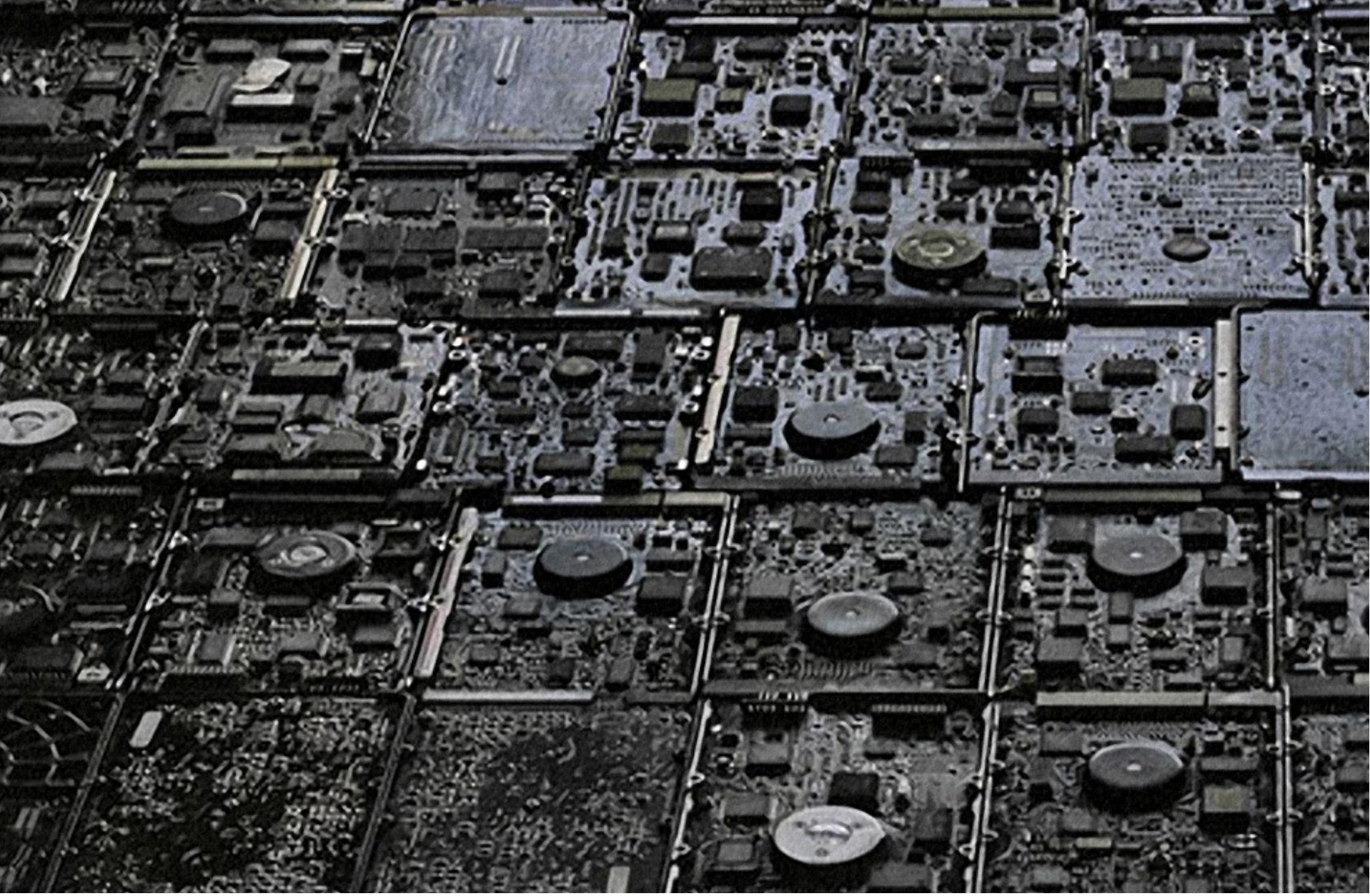




\section{$<$ na página anterior}

Figura 25. Circuit boards, Atlanta 2004

(Fonte: Ensaio fotográfico de Chris Jordan Intolerable Beauty: Portraits of American Mass Consumption 2003 - 2005 Disponível em http://www.chrisjordan.com/gallery/intolerable/\#circuit\%2oboards\%2044x64) 


\section{5 \\ Considerações finais}

O objetivo geral desta pesquisa foi identificar os tipos de obsolescência programada existentes hoje, assim como os principais produtos relacionados a ela, de modo a verificar se seria possível estabelecer uma relação entre este fenômeno e o design a partir da percepção dos consumidores e de designers de produto. Procurou-se fazer isso por meio da percepção de consumidores a respeito de práticas de consumo relacionadas ao fenômeno estudado, tendo como base teórica os conceitos de Packard (1965), Papanek (1971) e Slade (2007).

Os resultados mostraram que muitas das práticas de consumo descritas pelos autores acima citados, seguem válidas ainda hoje, porém de maneira mais naturalizada. Entende-se por naturalizada, uma prática tão comum, que torna-se automática ou imperceptível. Crédito e dificuldade de assistência técnica podem ser entendidas desta maneira pois foi identificado na pesquisa que a maioria das compras atualmente é feita em parcelas e muitas pessoas com dificuldades de assistência técnica acabam por trocar seus equipamentos.

No que diz respeito à durabilidade dos produtos, percebe-se uma divergência com tecnologia pois aparelhos eletroeletrônicos estão suscetíveis a diversos avanços, fazendo com que a questão da durabilidade torne-se menos relevante. O celular é um 
bom exemplo dessa divergência pois avanços tecnológicos acabam por inviabilizar seu uso prolongado, fazendo com que uma durabilidade física, deixe de ter importância frente a saltos tecnológicos. Por outro lado, no que diz respeito a produtos que não são passíveis de tantas mudanças tecnológicas, como móveis ou mesmo eletrodomésticos, há uma relação direta feita pelos participantes da pesquisa entre durabilidade e materiais, porém nem sempre seguindo a associação barato-frágil, caro-durável sugerida pelos autores. A variedade de relações entre esses conceitos observada na pesquisa remete também aos diferentes níveis de identificação e aceitação do fenômeno estudado, podendo-se encontrar diversos depoimentos de participantes que acreditam que tudo se quebrará, independente do custo, fazendo com que o conceito de durabilidade não só seja pouco valorizado, mas de certa maneira, algo impossível de ser encontrado. Neste sentido, a ideia de descartável torna-se ainda mais presente, pois na impossibilidade de manutenção de equipamentos ou em sua recorrente fragilidade, a troca dos equipamentos e eventual descarte dos mesmos, torna-se recorrente.

"Novo" não foi um conceito valorizado na coleta de dados por meio do questionário. Por outro lado, a preocupação com lançamentos esteve presente nas entrevistas realizadas.

Os resultados desta pesquisa indicam que as práticas de consumo relacionadas com a obsolescência programada deixaram de ser um aspecto isolado do consumismo, passando a ser uma prática enraizada, ainda que possam começar a ser observados também movimentos pontuais que vão na direção oposta a isso, como por exemplo os dados levantados pela pesquisa Akatu (2013), que mostra o crescimento de um consumo mais consciente.

Do ponto de vista pragmático e de práticas cotidianas os resultados sugeriram que há pouca informação entre os consumidores. Muitos identificam práticas relacionadas à obsolescência programada sem, contudo, conhecer suas consequências ou muitas vezes sem saber que se trata de uma estratégia imposta no passado. Diferentemente da década de 1960, época em o tema era era muito discutido, não se fala muito sobre obsolescência programada nos dias de hoje, seja nos círculos acadêmicos, seja na midia como um todo. Isso pode estar relacionado à naturalização das práticas e do fenômeno em si.

Os resultados mostraram que os três tipos de obsolescência descritos na literatura — psicológica, tecnológica e artificial —, assim como apontou Slade (2007), acabam por misturarem-se atualmente, tornando difícil a identificação de um tipo isolado. Ao mesmo tempo, o fenômeno em si tornou-se mais difundido. Neste sentido, é curioso ressaltar a confusão feita em todo o período da pesquisa entre o que é descartável e o 
que é obsolescência programada. Exemplos de produtos menores citados na pesquisa, como guarda-chuva ou mesmo as peças de vestuário citadas, indicam também a consolidação da associação do descartável com o fenômeno estudado. Pode-se considerar, portanto, que este é outro fator para a naturalização da obsolescência programada atualmente, pois a dificuldade de identificação de seus tipos, torna suas estratégias mais difusas. Da mesma maneira que torna-se difícil identificar tipos específicos de obsolescência, torna-se difícil separar os motivos para uma troca de equipamentos.

Os resultados mostraram que as práticas de consumo pesquisadas estão enraizadas no cotidiano fazendo com que a lógica das trocas funcione sem que seja necessário programar uma quebra ou uma obsolescência psicológica. Desta maneira, a obsolescência programada como conceito torna-se ultrapassada, pois produtos não precisam mais necessariamente serem feitos para quebrar para serem trocados, nem há mais a necessidade de lançamentos para que troquemos objetos.

Já no que se refere aos produtos mais associados ao fenômeno estudado, celular e computadores foram os mais citados. Pode-se considerar que o celular representa hoje, o que o carro simbolizou na década de 1920. No passado a indústria automobilística se valeu de características da moda para instituir os conceitos de obsolescência programada na comercialização de seus produtos, modificando a maneira como as coisas era fabricadas. Atualmente é o celular, que ao acumular diversas funções em um único objeto, modifica seu uso e comercialização tornando-se um item praticamente obrigatório.

De acordo com Forty (2007), o capitalismo foi benéfico para o design ao mesmo tempo que o design foi determinante para a instauração obsolescência programada. Para Lippincott (1947) e Forty, o design passa a ser valorizado como profissão no momento em que contribui para o aumento das vendas. Porém, se no passado as vendas aumentaram, induzidas também pelo atrativo estético atribuído ao design, atualmente, as práticas de consumo mostraram-se naturalizadas nesta pesquisa, mantendo o design por vezes na mesma lógica da década de 1920 como citado nas entrevistas com Gama e Batista. É importante destacar que, paralelamente à evolução e naturalização da obsolescência programada, a profissão de designer também evoluiu, estando cada vez mais voltada para uma visão sistêmica da produção dos artefatos, de acordo com a defição do WDO vista anteriormente.

Não é possível, contudo, fazer afirmações a respeito do papel do design dentro das empresas de maneira geral, devido ao número reduzido de entrevistas realizadas. Também não é possível relacioná-lo com a obsolescência programada de manei- 
ra mais específica. A importância desta discussão para o campo do design portanto, consiste em refletir sobre a diferença de premissas de projeto propostas por Whiteley (1993), definidas por ele como market-lead e product-lead design. Enquanto a primeira opera dentro da lógica da obsolescência programada - e o design acaba muitas vezes, por limitar sua atuação às poucas etapas do processo de desenvolvimento de produtos mais voltadas às características estéticas - a segunda permite que designers exerçam sua função social de acordo com características definidas pelo WOD para a profissão, que prevê um desenho de produtos mais conectado com contexto em que estão inseridos, propondo constantes melhoras na sociedade.

A partir dos resultados obtidos no questionário e nas entrevistas, a locação ou o compartilhamento dos produtos se apresentam-se como possíveis alternativas à obsolescência. Como sugerido por Papanek (1965), e observado também no caso da BMW — que prevê a logística reversa de seus carros desde o momento de sua fabricação-, o design para desmontagem modifica a maneira como são feitos os artefatos. Da mesma maneira, artefatos produzidos para locação são fabricados com premissas de projeto diferentes do que para venda, pois devem contemplar questões de durabilidade por exemplo.

Não pretendeu-se com esta pesquisa esgotar um tema desta amplitude e pertinência, mas espera-se que ele possa contribuir para uma reflexão sobre a obsolescência programada e suas consequências, podendo colaborar de alguma maneira para a melhoria deste cenário.

\subsection{Sugestões para futuras pesquisas}

No que diz respeito à pesquisa realizada, a população alcançada acabou por trazer respostas sobre o comportamento de uma parcela pequena da população brasileira (com grande poder aquisitivo e alta escolaridade). Seria interessante contrapor os dados levantados com uma população com diferentes características para identificar diferenças e semelhanças, sendo possível inferir se gênero e renda seriam determinantes em relação ao tema pesquisado. Ou seja, o desenho de uma pesquisa quantitativa com amostragem estratificada e relevância estatística seria interessante.

Faixa etária apresenta-se também como um caminho possível para futuras pesquisas devido ao fato de estar significativamente associada à importância da assistência técnica e da durabilidade, apontando para uma possível associação geracional com o conceito da obsolescência programada. 



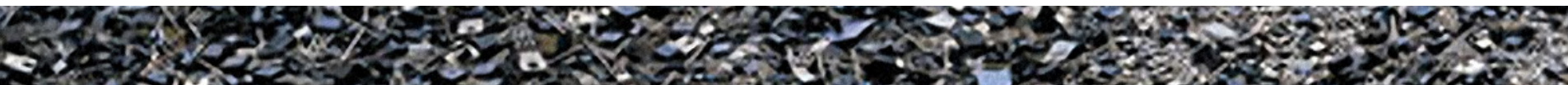
F,

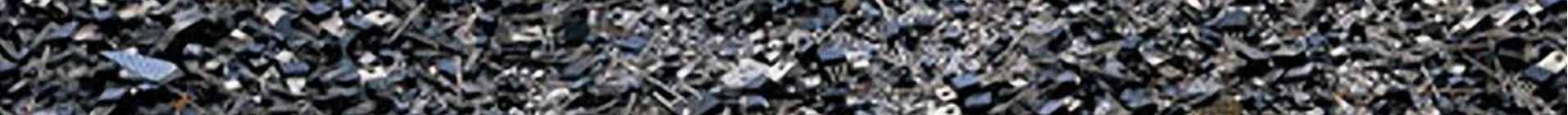

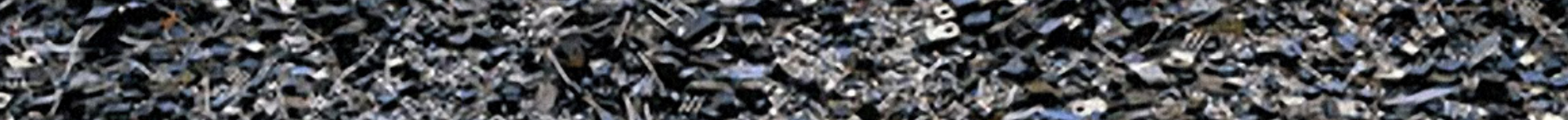

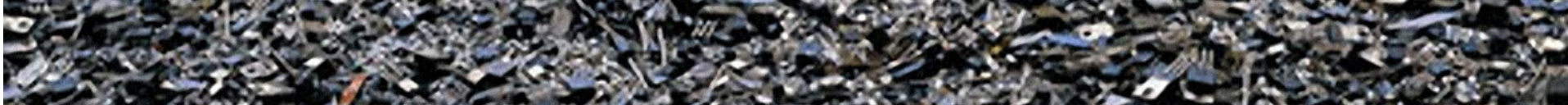
3.

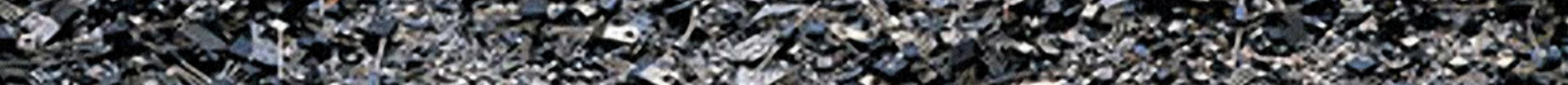

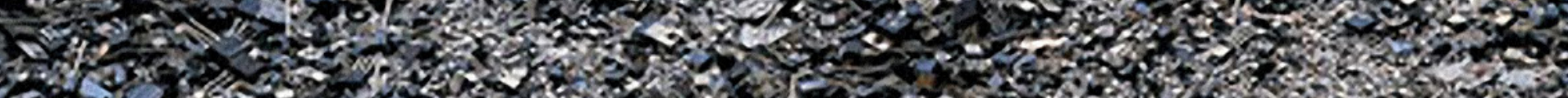

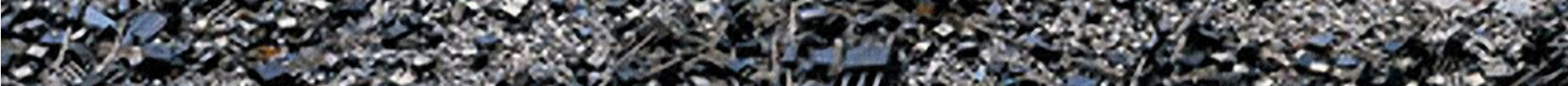
1.0.4. 3.

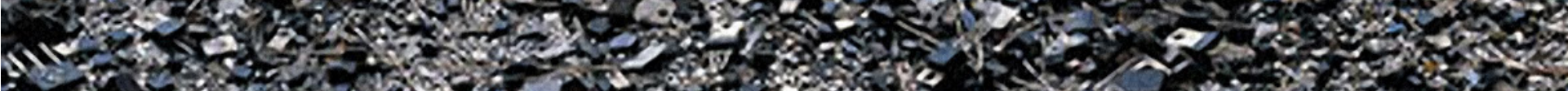
- .

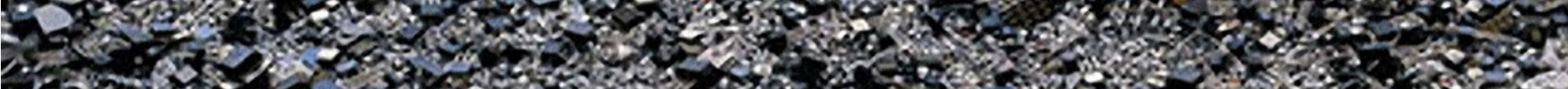

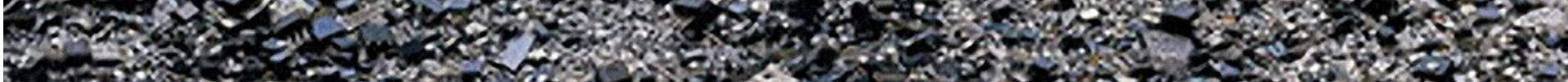

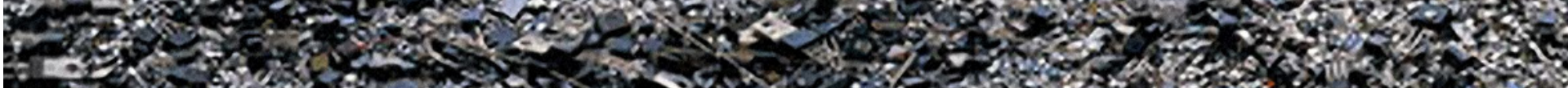

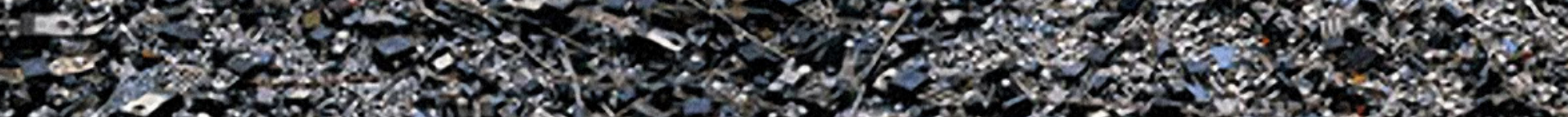
mb. 40 .

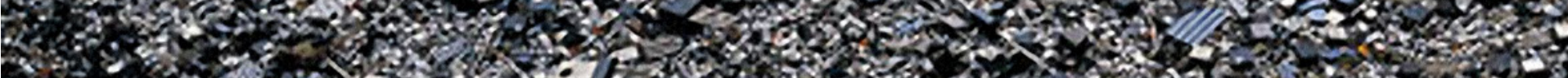

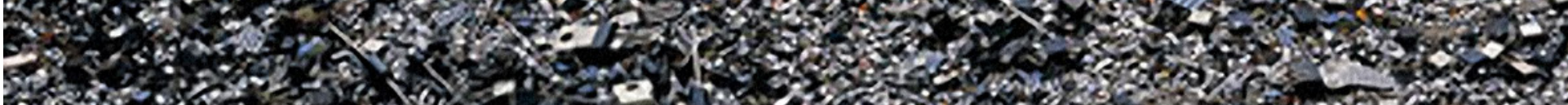
the

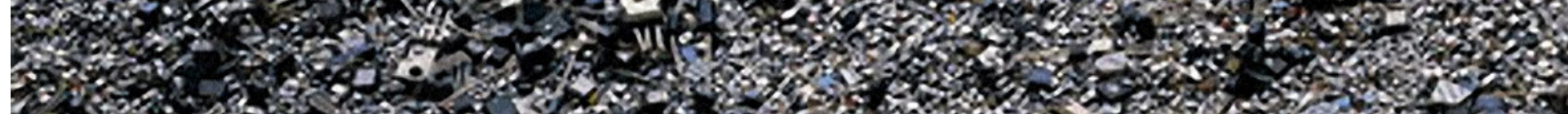
4.

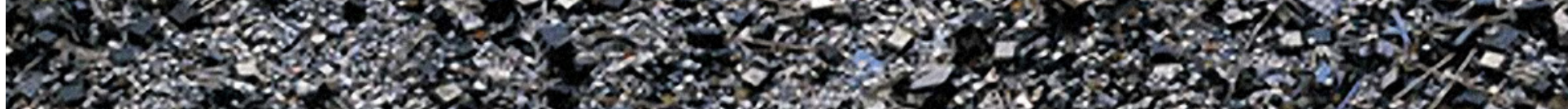

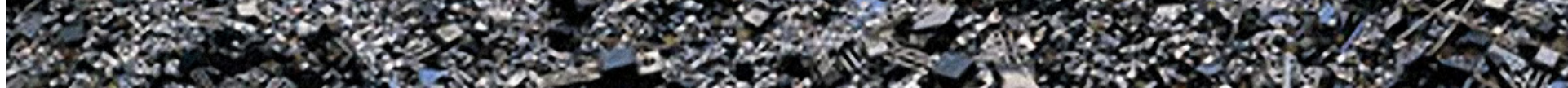
25.

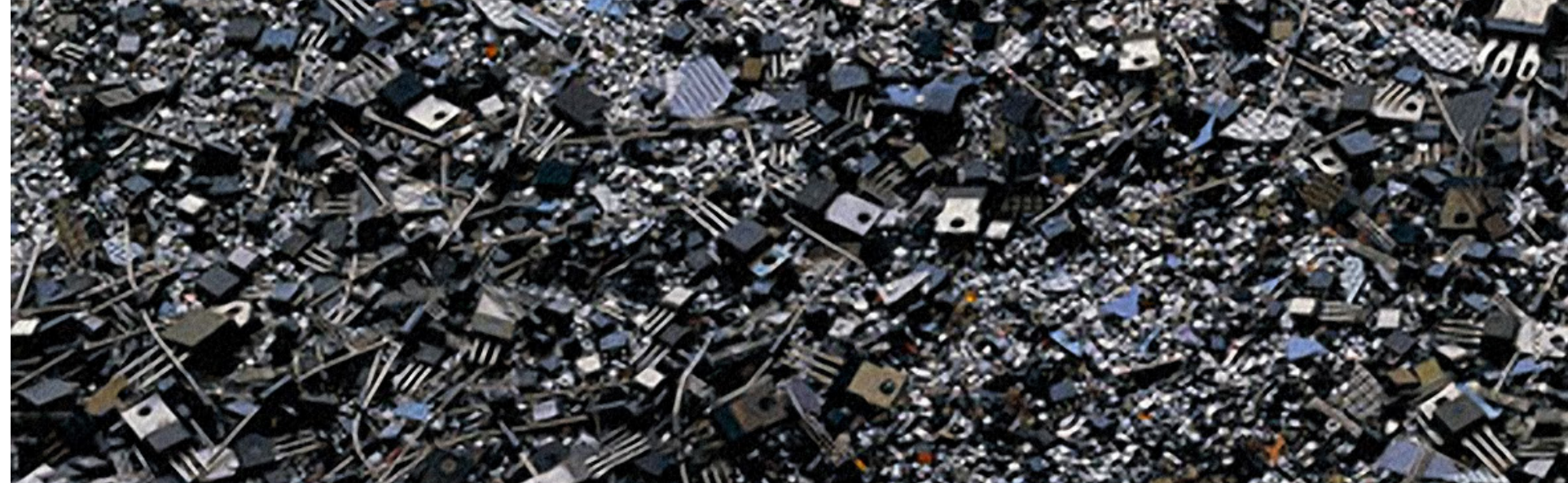
10. 
72 .

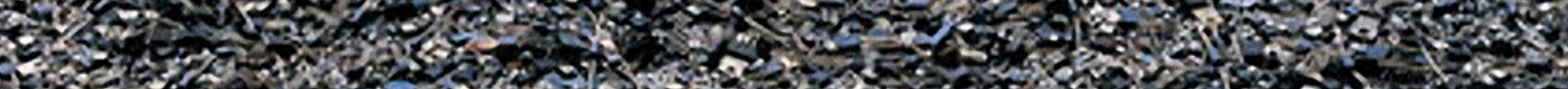

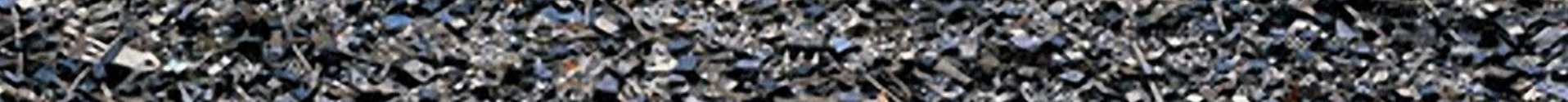

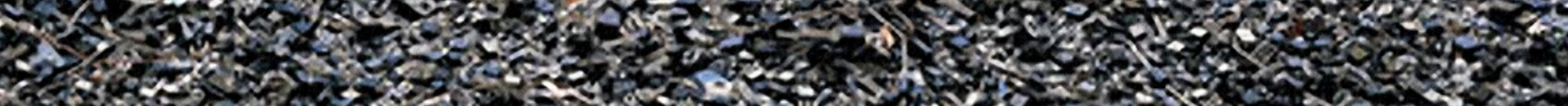

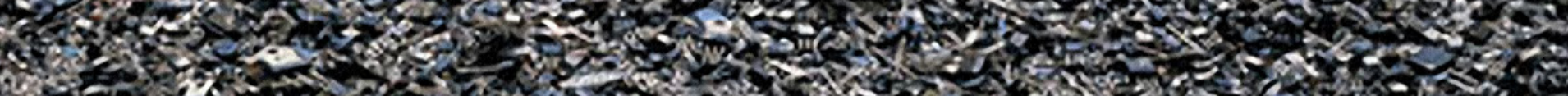

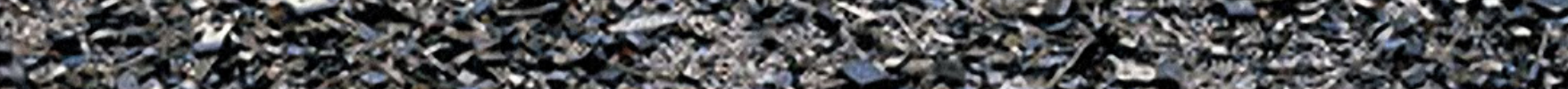

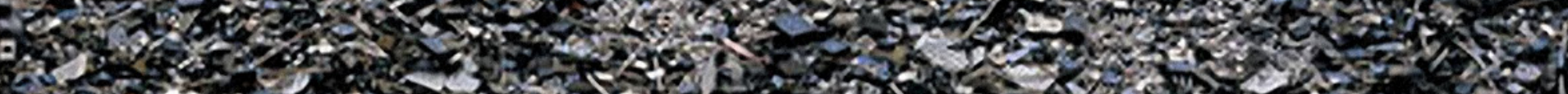
3.

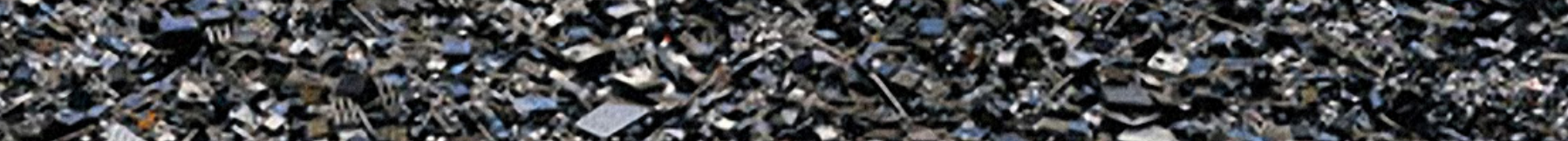

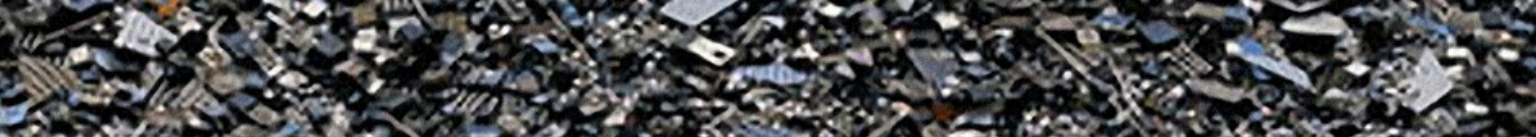
2. 7. 2.

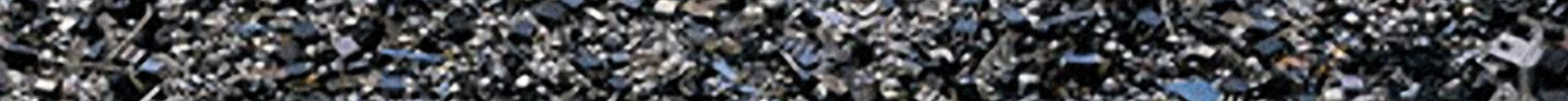

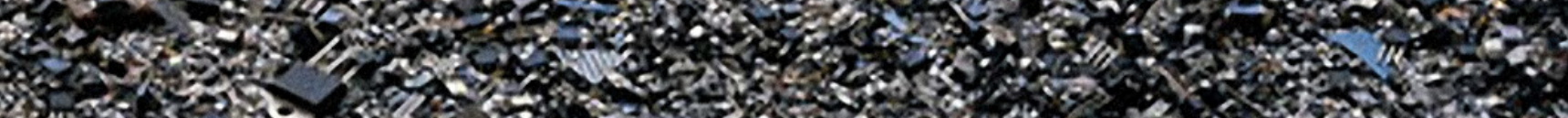

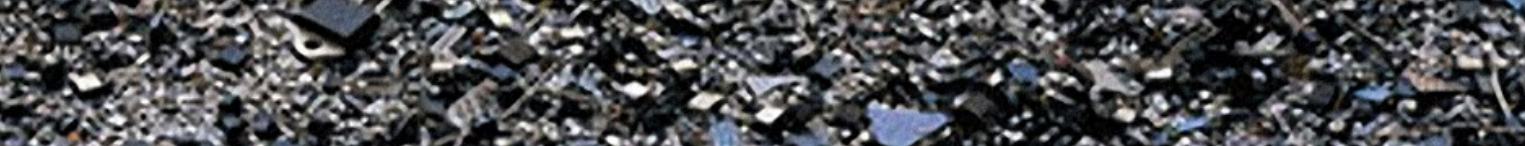

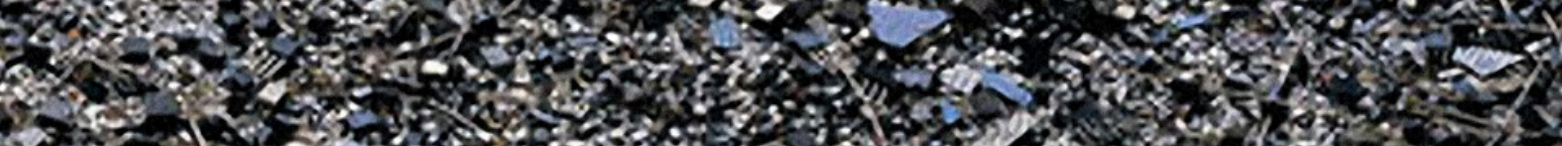

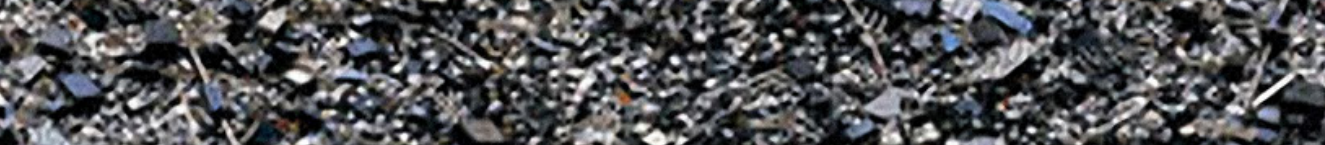
1.7, 1

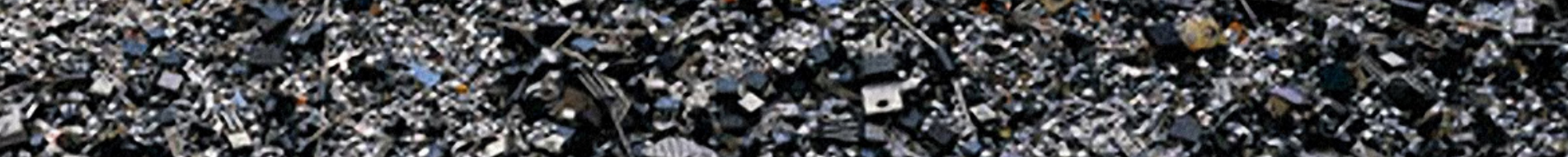
4.

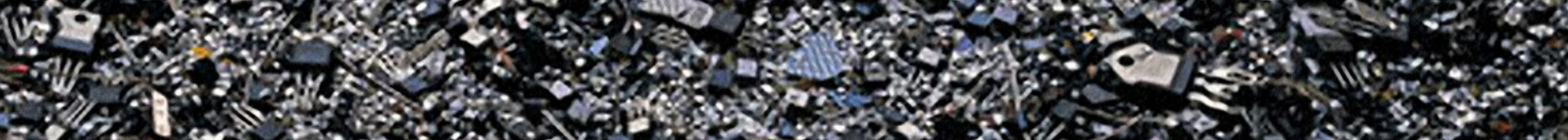

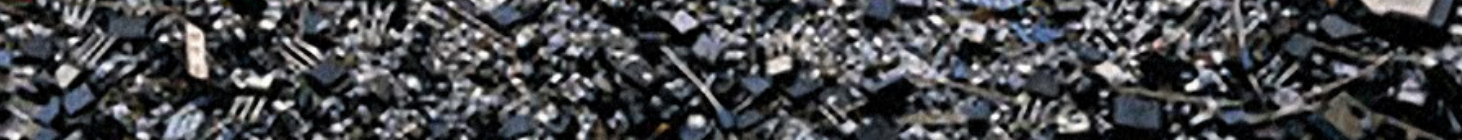

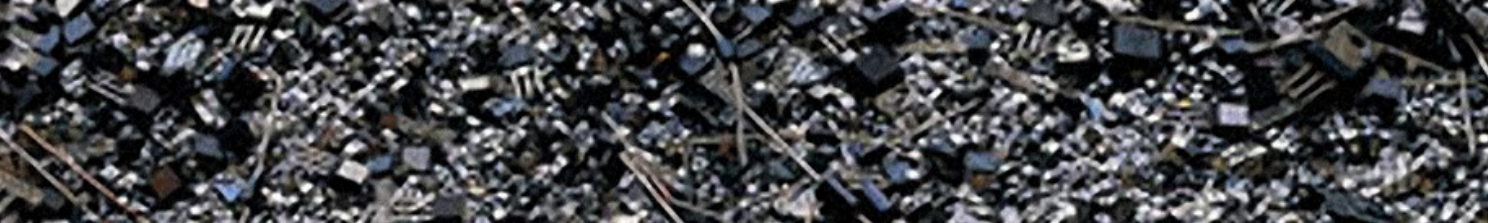

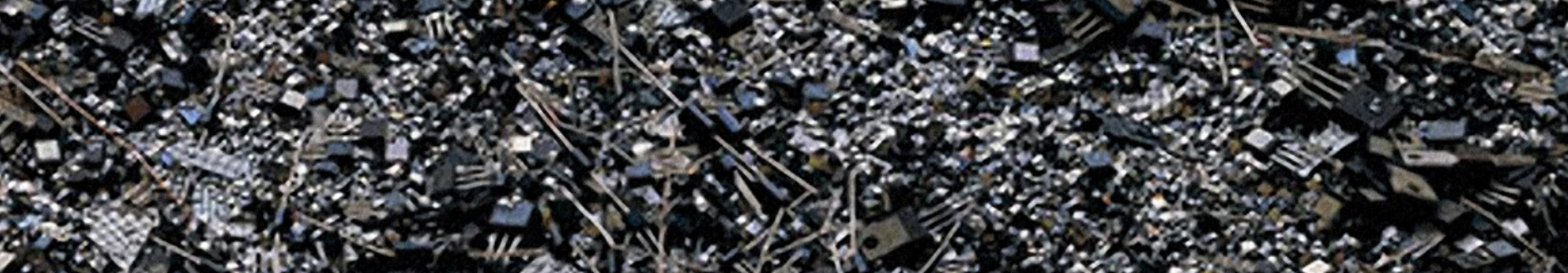

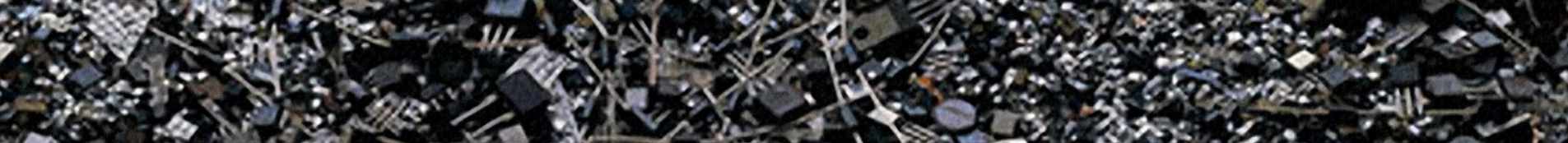

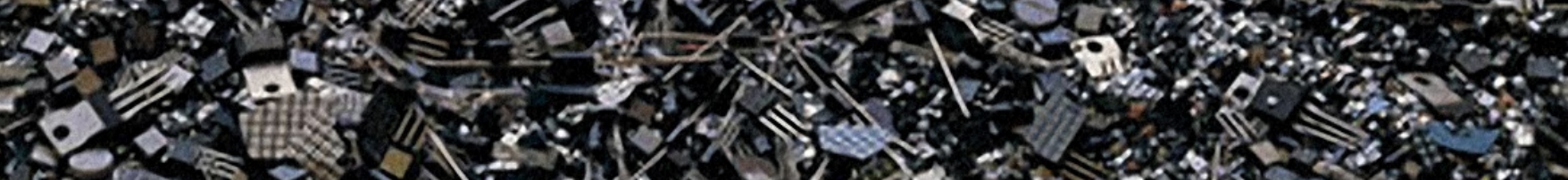




\section{$<$ na página anterior}

Figura 26. E-waste, New Orleans 2005.

(Fonte: Ensaio fotográfico de Chris Jordan Intolerable Beauty: Portraits of American Mass Consumption 2003 - 2005 Disponível em http://www.chrisjordan.com/gallery/intolerable/\# ewaste\%2044x57) 


\section{Referências bibliográficas *}

ARAUJO, Bruno. Por que as telas dos celulares quebram tanto e por que é tão caro consertar? G1, 25 jul. 2017. Disponível em: http://g1.globo.com/tecnologia/noticia/por-que-as-telas-dos-celulares-quebramtanto-e-por-que-e-tao-caro-consertar.ghtml. Acesso em: 21 ago. 2017.

AZEVEDO, Ana Lucia. Annie Leonard: a revolução do consumo e da felicidade. O Globo, 10 jan. 2012. Disponível em: https://oglobo.globo.com/sociedade/ciencia/annie-leonard-revolucao-do-consumo-dafelicidade-3629246. Acesso em: 15 ago. 2017.

BARBOSA, Vanessa. Suécia quer reduzir imposto para estimular cultura do reparo. Exame, 21 set. 2016. Disponível em: http://exame.abril.com.br/economia/suecia-quer-reduzir-imposto-para-estimular-cultura-do-reparo. Acesso em: 15 ago. 2017.

BAUMAN, Zygmunt. Vida para consumo: a transformação das pessoas em mercadorias. Rio de Janeiro: Zahar, 2008.

BONSIEPE, Gui. Design, cultura e sociedade. São Paulo: Blucher, 2011.

BRAGA, Marcos da Costa (Org.). Papel social do design gráfico: história, conceitos \& atuação profissional. Senac SP, 2011.

BRASIL. Lei n ${ }^{0}$ 8.078, de 11 de setembro de 1990. Dispõe sobre a proteção do consumidor e dá outras providências. Disponível em: http://www.planalto.gov.br/ccivil_03/leis/L8078.htm. Acesso em: 21 ago. 2017.

. Lei $\mathrm{n}^{0}$ 12.305, de 2 de agosto de 2010. Institui a Política Nacional de Resíduos Sólidos; altera a Lei no 9.605, de 12 de fevereiro de 1998; e dá outras providências. Disponível em: http://www.planalto.gov.br/ccivil_03/_ato2007-2010/2010/lei/112305.htm. Acesso em: 21 ago. 2017.

. Agência Nacional de Telecomunicações (Anatel). Brasil encerra junho com 242,1 milhões de linhas móveis em operação. Agência Nacional de Telecomunicações, 27 jul. 2017. Disponível em: http:// www.anatel.gov.br/dados/component/content/article?id=283. Acesso em: 15 ago. 2017.

CARROS AUTÔNOMOS chegarão antes do esperado, diz presidente da GM. G1, 12 jul. 2016. Disponível em: http://g1.globo.com/carros/noticia/2016/o7/carros-autonomos-chegarao-antes-do-esperado-diz -presidente-da-gm.html. Acesso em: 21 ago. 2017.

COMPRAR, TIRAR, COMPRAR. Direção: Cosima Dannoritzer. Produção: Joan Úbeda. Barcelona: Media 3.14, 2010. Disponível em: http://www.youtube.com/watch?v=3pb7HOfp8PU.

CRESWELL, John W. Projeto de pesquisa: métodos qualitativo, quantitativo e misto. 3. ed. Porto Alegre: Artmed, 2010.

DODD, Frank Anthony Barral. Análise quantitativa da ocorrência de imagens de produtos na bibliografia de design para verificação de fidedignidade do conjunto destas imagens como representação do campo de atividade do design de produto. Tese (doutorado) - Faculdade de Arquitetura e Urbanismo, Universidade de São Paulo, São Paulo, 2011.

ECHEGARAY, Fabián. Consumer's reactions to product obsolescence in emerging markets: the case of Brazil. Journal of Cleaner Production, v. 134A, p. 191-203, 2016. Disponível em: http://dx.doi.or$\mathrm{g} / 10.1016 / \mathrm{j}$.jclepro.2015.08.119. Acesso em: 10 maio 2017.

* De acordo com a Associação Brasileira de Normas Técnicas (ABNT NBR 6023). 
ESTATÍSTICAS DE USO de celular no Brasil. Opus Software, 18 abr. 2016. Disponível em: https://www. opus-software.com.br/estatisticas-uso-celular-brasil. Acesso em: 21 ago. 2017.

E-WASTE DEFINITION. Ewasteguide.info, [s. d.]. :. Acesso em: 21 ago. 2017.

FLICK, Uwe. Uma introdução à pesquisa qualitativa. Porto Alegre: Bookman, 2004.

FORTY, Adrian. Objetos de desejo: design e sociedade desde 1750. São Paulo: Cosac Naify, 2007.

FREITAS, Vladimir Passos de. Obsolescência programada precisa ser reprimida nos tribunais do país. Consultor Jurídico, 4 jun. 2017. Disponível em: http://www.conjur.com.br/2017-jun-04/segunda-leitura -obsolescencia-programada-reprimida-tribunais. Acesso em: 21 ago. 2017.

GM LANÇA marca Maven para competir com Uber e Zipcar. Valor Econômico, 21 jan. 2016. Disponível em: http://www.valor.com.br/empresas/4404878/gm-lanca-marca-maven-para-competir-com-uber-ezipcar. Acesso em: 21 ago. 2017.

IDEC; MARKET ANALYSIS. Ciclo de vida de eletrônicos. [s.l.]: Idec; Market Analysis, 2013.

INSTITUTO AKATU. Pesquisa Akatu 2012: rumo à sociedade do bem-estar.LEON, Ethel. Design brasileiro: quem fez, quem faz. Rio de Janeiro: Ed. Senac RJ, 2005.

LIPPINCOTT, Gordon. Design for business. Chicago: Paul Theobald, 1947.

MANZINI, Ezio. Design para a inovação social e sustentabilidade: comunidades criativas, organizações colaborativas e novas redes projetuais. Rio de Janeiro: E-papers, 2008.

OS CELULARES ANTIGOS recebem a primeira medalha de Tóquio 2020. PlayGround BR, 17 fev. 2017. Disponível em: https://www.facebook.com/PlayGroundBR/videos/334230843638567/?hc_ref=ARTw2lrXx umeAiUqXmtej4YjUCkVBOJPN5XSY5zp4Cqpiw66H9O23r4aeXKQqR8lkHQ. Acesso em: 15 ago. 2017.

PACKARD, Vance. Estratégia do desperdício. São Paulo: Ibrasa, 1965.PADILHA, Valquíria. Desejar, comprar e descartar: da persuasão publicitária à obsolescência programada. Ciência e Cultura, v. 68, n. 4, pp. 46-49, 2016. Disponível em: http://cienciaecultura.bvs.br/pdf/cic/v68n4/v68n4a15.pdf. Acesso em: 17 maio 2017 .

PAPANEK, Victor. Design for the real world: human ecology and social change. 2. ed. Chicago: Academy Chicago, 1971.

. Arquitectura e design: ecologia e ética. Lisboa: Edições 70, 2014.

PAYÃO, Felipe. As 5 marcas de smartphone mais vendidas de 2016. Tecmundo, 23 ago. 2016. Disponível em: https://www.tecmundo.com.br/celular/108747-5-marcas-smartphone-vendidas-2016.htm. Acesso em: 21 ago. 2017.

PLATCHECK, Elizabeth R. Design industrial: metodologia de ecodesign para o desenvolvimento de produtos sustentáveis. São Paulo: Atlas, 2012

REDIG, Joaquim. Design: responsabilidade social no horário do expediente. In: BRAGA, Marcos da Costa (Org.). O papel social do design gráfico: história, conceitos \& atuação profissional.. Senac SP, 2011.

RECICLAGEM NA BMW. BMW, [s.d.]. Disponível em: http://www.bmw.pt/pt/topics/offers-and-services/ personal-services/recycling.html. Acesso em: 7 jun. 2016.

RODA VIVA, 21 jan. 2013. Entrevista com Domenico De Masi.Disponível em: https://www.youtube. com/watch?v=MSEUPqHnv14. Acesso em: 25 ago. 2016.RODRIGUES, Aroldo. Psicologia social para iniciantes. Petrópolis: Vozes, 2005. 
RUCEVSKA, Ieva et al. Waste crime - waste risks: gaps in meeting the global waste challenge. Arendal: Unep; Grid-Arendal, 2015.

SEVCENKO, Nicolau. A corrida para o século XXI: no loop da montanha russa. São Paulo: Companhia das Letras, 2001.

SILVA, Cleide. GM entra na briga e lança serviço similar ao Uber no Brasil. Exame, 10 jun. 2016. Disponível em: http://exame.abril.com.br/negocios/gm-lanca-no-pais-projeto-de-carro-compartilhado. Acesso em: 21 jul. 2017.

SLADE, Giles. Made to break: technology and obsolescence in America. Cambridge: Harvard University Press, 2007.

SUÉCIA INAUGURA shopping que só vende produtos de segunda mão. Ciclo Vivo, 12 abr. 2017. Disponível em: http://ciclovivo.com.br/noticia/suecia-inaugura-shopping-que-so-vende-produtos-de-segunda-mao. Acesso em: 15 ago. 2017.

SWISS E-WASTE PROGRAMME. Ewasteguide.info, [s. d.]. Disponível em: http://ewasteguide.info/swiss -e-waste-programme. Acesso em: 15 jul. 2017.

THE MAN who made us spend. Episódio 1. Produtor: Mike Radford. Produção executiva: Dermot Caulfield. Apresentador: Jacques Peretti. BBC, 2014. Disponível em: https:/videosift.com/video/BBC-TheMen-Who-Made-Us-Spend. Acesso em: 12 ago. 2017.WDO. Definition of industrial design.

WDO, [s.d.]. Disponível em: http://wdo.org/about/definition. Acesso em: 17 ago. 2017.

WHITELEY, Nigel. Design for society. Londres: Reaktion, 1993.

ZACAR, Cláudia Regina Hasegawa. Design e flexibilidade : estratégias para o gerenciamento da obsolescência de telefones celulares. Dissertação (mestrado) - Universidade Federal do Paraná, Curitiba, 2010. 



\title{
Apêndice 1
}

\section{Questionário: Pesquisa sobre práticas de consumo de bens de consumo duráveis}

\begin{abstract}
Este questionário faz parte de uma pesquisa de mestrado em andamento na área de design da FAU-USP. As respostas são muito importantes, pois procuramos saber um pouco das práticas e dos hábitos de consumo do maior número de pessoas.Estimamos que você demorará em torno de 15 minutos para preencher esse questionário. Vale lembrar que nenhuma das informações fornecidas será divulgada, ou seja, seus dados serão tratados de forma confidencial.Os asteriscos vermelhos assinalam campos de resposta obrigatória, indicados com o termo em inglês "answer required"; "short answer" é uma resposta curta; "long answer" é uma resposta longa; "other" é um campo complementar que pode ser utilizado quando você não encontrar uma resposta que considera adequada. Se puder compartilhar o questionário com pessoas que talvez se interessem pelo tema e que tenham disponibilidade de respondê-lo, agradecemos muito!
\end{abstract}

Obrigado!

1_Nome
2_Gênero*
[ ] Feminino
[ ] Masculino
[ ] Outro

3_Idade *

\section{4_Escolaridade * \\ [ ] Fundamental incompleto \\ [ ] Fundamental completo \\ [ ] Ensino médio incompleto \\ [ ] Ensino médio completo \\ [ ] Superior completo \\ [ ] Prefiro não declarar}

\section{5_Profissão *}

* os asteriscos marcam os campos obrigatórios
6_Cidade onde mora

\section{7_Cidade onde Estado}

\section{8_Bairro onde mora}

\section{9_Renda familiar}

[ ] até $\mathrm{R} \$ 1.076,20$ (1 salário mínimo)

[ ] de $\mathrm{R} \$ 1.076,20$ a R \$2.152,40 (1 a 2 salários mínimos)

[ ] de $\mathrm{R} \$ 2.152,40$ a $\mathrm{R} \$ 3.228,60$ (2 a 3 salários mínimos)

[ ] de $\mathrm{R} \$ 3.228,60$ a $\mathrm{R} \$ 4.304,80$ (3 a 4 salários mínimos)

[ ] de $\mathrm{R} \$ 4.304,80$ a $\mathrm{R} \$ \mathbf{5 . 3 8 1 , 0 0}$ (4 a 5 salários mínimos)

[ ] de $\mathrm{R} \$ 5.381,00$ a $\mathrm{R} \$ 6.457,20$ (5 a 6 salários mínimos)

[ ] de $\mathrm{R} \$ 6.457,20$ a $\mathrm{R} \$$ 7.533,40 (6 a 7 salários mínimos)

[ ] mais de $\mathrm{R} \$ \mathrm{R} \$ 7.533,40$ (7 salários mínimos)

[ ] Prefiro não declarar

10_Número de moradores na sua residência 


\section{[1. sobre práticas de consumo]}

As perguntas a seguir referem-se aos hábitos e práticas de consumo de produtos que, ainda que não sejam rigorosamente considerados bens de consumo duráveis pelo mercado, exigem certo planejamento antes da sua compra e, por esta razão, nos fazem esperar que durem.

São bons exemplos desses produtos: automóvel ou moto, celular, computador, móveis, dvd, câmera fotográfica, televisor, micro-ondas, impressora, geladeira, freezer, lavadora ou secadora de roupas, fogão, aparelho de ar condicionado, aparelho de som, cafeteira, torradeira, entre outros de que você pode se lembrar.

11_De maneira geral, quando seus bens de consumo duráveis apresentam defeitos, você costuma:

[ ] Sempre tentar consertá-los

[ ] Descartá-los e comprar um novo

[ ] Outro

12_Sobre práticas de consumo, você costuma:

[ ] Usar os produtos pelo maior tempo possível

[ ] Trocá-los sempre que uma nova versão é colocada no mercado

[ ] Outro

13_Você leva em consideração a durabilidade do produto no momento da compra?

[ ] Sim [ ] Não [ ] Depende do produto

14_Explique.

15_Na sua opinião, a assistência técnica dos produtos é algo importante na decisão de compra?

[ ] Sim [ ] Não [ ] Depende do produto

16_Explique.

17_Costuma comprar produtos usados?

[ ] Sim [ ] Não [ ] Depende do produto

18_Assinale os produtos que já comprou usados, marque quantas opções julgar necessário. (mais de uma escolha)

[ ] Eletrodomésticos

[ ] Celular

[ ] Carro
[ ] Digitais (computador, câmera, tablet...)

[ ] Móveis

[ ]

[ ] Não costumo comprar produtos usados

19_Explique.

20_Você costuma comprar produtos apenas por ser um lançamento?

[ ] Sim [ ] Não [ ] Depende do produto

21_Assinale os produtos que compra apenas por ser um lançamento, marque quantas opções julgar necessário. (mais de uma escolha)

[ ] Eletrodomésticos

[ ] Celular

[ ] Carro

[ ] Digitais (computador, câmera, tablet...)

[ ] Móveis

[]

[ ] Não costumo comprar produtos por serem lançamentos

22_0 que mais atrai você nos lançamentos? (mais de uma escolha)

[ ] Uma nova aparência.

[ ] Uma nova função ou avanço tecnológico.

[ ]

[ ] Não costumo comprar produtos por serem lançamentos

23_Como você costuma pagar pelos produtos?

[ ] à vista

[ ] a crédito (cartão de crédito ou parcelado no cartão ou carnê), em poucas parcelas

[ ] a crédito(cartão de crédito ou parcelado no cartão ou carnê), no maior número de parcelas possível

24_Em relação à frase "O que é novo é bom e o que é antigo é ruim" você:

[ ] Concorda totalmente com esta frase

[ ] Concorda parcialmente com esta frase

[ ] Não concordo nem discordo

[ ] Discorda parcialmente com esta frase

[ ] Discorda totalmente com esta frase

25_Comente a resposta acima, se quiser. 
26_Em relação à frase "Se um produto é barato pode durar pouco, se é caro deve durar muito" você:

[ ] Concorda totalmente com esta frase

[ ] Concorda parcialmente com esta frase

[ ] Não concordo nem discordo

[ ] Discorda parcialmente com esta frase

[ ] Discorda totalmente com esta frase

27_Comente a resposta acima, se quiser.

28_Considerando suas últimas compras de bens de consumo duráveis, você ficou satisfeito(a) com o valor que foi pago por ele? [ ] Sim [ ] Não [ ] Não sei

29_Considerando suas últimas compras de bens de consumo duráveis, você ficou satisfeito(a) com o tempo que ele durou pelo valor que foi pago?

[ ] Sim [ ] Não [ ] Não sei

30_Por que? (por favor, comente a resposta acima)

\section{[2. sobre prodtos]}

As perguntas a seguir referem-se aos produtos que, ainda que não sejam rigorosamente considerados bens de consumo duráveis pelo mercado, exigem certo planejamento antes da sua compra e, por esta razão, nos fazem esperar que durem.

São bons exemplos desses produtos: automóvel ou moto, celular, computador, móveis, dvd, câmera fotográfica, televisor, micro-ondas, impressora, geladeira, freezer, lavadora ou secadora de roupas, fogão, aparelho de ar condicionado, aparelho de som, cafeteira, torradeira, entre outros de que você pode se lembrar.

31_Qual foi o último produto que você comprou? (Ou a última compra que considere importante)

[ ] Eletrodomésticos de grande porte (geladeira, fogão, máquina de lavar roupa, ar condicionado, televisão, micro-ondas...)

[ ] Eletrodomésticos de pequeno ou médio porte (torradeira, ferro de passar roupa, secador de cabelo, impressora...)

[ ] Celular ou smartphone

[ ] Automóveis (carro, moto, bicicleta)
[ ] Digitais (câmera, tablet...)

[ ] computador ou leptop (câmera, tablet...)

[ ] Móveis

[ ]

32_Especifique o bem adquirido.

[ ]

32_Comprou um modelo

[ ] novo [ ] usado

33_Por que motivo comprou?

[ ] Não tinha, precisava de um

[ ] Um modelo mais bonito foi lançado e decidi comprá-lo

[ ] O que eu tinha antes quebrou

[ ] O que eu tinha antes não atendia mais às minhas necessidades

[ ] O que eu tinha antes ficou tecnologicamente ultrapassado [ ]

34_Se assinalou a alternativa "quebrou" ou a alternativa "não atendia mais às minhas necessidades" na resposta anterior, descreva o que aconteceu. 0 que quebrou? Como quebrou? Por que não atendia mais às suas necessidades?

35_Gostaria que ele tivesse durado mais?

[ ] Sim [ ] Não

36_Quanto tempo o aparelho antigo durou?

37_Quanto tempo acha que que ele deveria ter durado?

38_Teria comprado um novo modelo, mesmo que o anterior não tivesse quebrado?

[ ] Sim [ ] Não

39_Caso tenha quebrado, procurou uma assistência técnica para tentar consertar?

[ ] Sim [ ] Não

40_Caso tenha quebrado e tentou consertar, mas ainda assim teve que comprar um novo, o que não deu certo? (organizar pra só aparecer essa pergunta quando a pessoa responder que quebrou) 
[ ] O conserto era muito caro

[ ] Não foi possível consertar por falta de peças

[ ] Não foi possível consertar porque conserto demoraria muito

[ ] Pelo preço, valia mais a pena comprar um novo

[ ] Não encontrei nenhuma assistência técnica que consertasse [ ]

41_0 que você fez com o modelo anterior?

[ ] Dei para um amigo/familiar

[ ] Joguei no lixo

[ ] Doei para uma instituição de caridade

[ ] Vendi

[ ] Mantive e uso os dois

[ ] Está lá no canto, não sei o que fazer com ele [ ]

42_Qual é o bem de consumo durável que você troca com mais frequência?

43_Por que troca com frequência?

44_Qual o bem de consumo durável mais antigo que você possui?

45_Há quanto tempo está em uso?

46_E o mais antigo mas que não está em uso?

47_Por que está guardado se não está mais em uso?

\section{[3. sobre o tema da obsolescência]}

48_Você conhece o termo obsolescência programada?

\section{[ ] Sim [ ] Não}

A obsolescência programada é o nome que se dá a estratégia de mercado que reduz o tempo de vida de um produto motivando o consumidor (ou nos obrigando mesmo) a comprar um novo ou a comprar um produto muitas vezes. De maneira geral, essa redução do tempo de vida do produto pode acontecer de três maneiras: a) pelo lançamento de um produto em uso com uma nova aparência, ou seja, um novo modelo é lançado despertando o desejo de compra, seja pela beleza ou por você passar a achar o produto que tem velho e utrapassado; b) pela impossibilidade de conserto do produto, ou seja, você procura uma assistência técnica, mas não consegue arrumar seu aparelho/produto por falta de peças ou por não valer a pena financeiramente e o conserto acabar saindo mais caro do que a compra de um produto novo; c) pela tecnologia não funcionar mais, tornando lentos alguns dispositivos ou impossibilitando o uso do equipamento em alguns casos (celulares e computadores são um exemplo bom desse tipo problema: pode acontecer de não ser possível baixar um aplicativo no celular ou de instalar um determinado programa no computador por conta de sua versão mais antiga, fazendo com que seja necessário comprar um novo equipamento). (só aparecer a definição quando a pessoa responder a pergunta anterior)

49_Você identifica esta estratégia/prática no seu cotidiano?

[ ] Sim [ ] Não [ ] Não sei

50_De que maneira?

51_A que parte das empresas você associaria esta estratégia/prática?

[ ] Departamento de propaganda

[ ] Departamento de design dos produtos

[ ] Departamento financeiro

[ ] Não sei

[ ]

\section{2_Por que?}

53_Essa prática (obsolescência programada) incomoda você de alguma maneira?

[ ] Sim [ ] Não [ ] Não sei

54_Por que? O que você acha que poderia mudar?

Obrigado por participar da pesquisa!

Se quiser acrescentar algo às suas respostas, por favor, envie e-mail para liaassumpcao@usp.br com suas considerações.

Após a análise dos dados, alguns participantes poderão ser convidados a participar de uma entrevista em profundidade sobre o mesmo assunto.Você concordaria em participar?

[ ] Sim [ ] Não

Por favor, deixe seu e-mail para contato. 


\section{Apêndice 2}

\section{Roteiro para entrevista com designers}

Informações pessoais do entrevistado: nome, cargo, tempo de empresa

Perfil da empresa: que produtos vende, número de modelos fabricados e vendidos atualmente, vendas por ano, periodicidade de lançamentos, como são feitas as atualizações.

\section{Sobre o departamento de design}

Existe departamento de design no Brasil? | Há projetos desenvolvidos aqui? | Qual a relação entre o departamento de design central e o local? | De quais etapas de desenvolvimento do produto, o design participa efetivamente? Na decisão do produto a ser comercializado ou a partir desta decisão? | O design tem autonomia dentro da empresa? Responde a quem? (marketing, financeiro)

\section{Sobre o desenvolvimento de produto}

Quais são as premissas de projeto? (economia, sustentabilidade, design) | Com qual frequência são apresentados novos modelos de produtos? | Existe uma demanda interna desta frequência?|Em que são pautadas principalmente as mudanças nos produtos? (aparência, funcionalidade, tecnologia) | São feitas pesquisas para desenvolvimentos de novos produtos?|Se sim, que tipo? De mercado? De satisfação do cliente?

\section{Sobre legislação}

São feitas alterações e ou adequações de modelos desenvolvidos fora mas fabricados e/ou comercializados aqui? | Quais as maiores diferenças de legislação entre os países? | Isso interfere no desenho dos produtos? | Qual é a preocupação com a Lei de Resíduos Sólidos? Há intenção da empresa de aderir a uma estratégia de logística reversa?

\section{Sobre práticas sustentáveis}

Existe um pensamento de utilizar peças similares para diversos produtos barateando sua produção? | Existe uma preocupação com a assistência técnica dos produtos vendidos? (tanto no que diz respeito a oferecer unidades e equipes de assistência técnica como pensar o produto de maneira a ser consertado) Existe uma pesquisa de materiais? Uma preocupação com materiais mais sustentáveis talvez?

\section{Sobre obsolescência programada}

Qual a visão da empresa sobre a prática de obsolescência programada? | Ela é levada em consideração no desenvolvimento de produtos? | Você acha que os produtos desenvolvidos por vocês colaboram contra ou a favor desta tendência de alguma maneira? | Você acredita que o design tenha alguma relação com essa prática ou ela deriva de outros setores? 

Anexo 1

Relatório CEA-USP

165 


\section{CENTRO DE ESTATÍSTICA APLICADA - CEA - USP RELATÓRIO DE CONSULTA}

TíTULO: "Pesquisa sobre práticas de consumo de bens de consumo duráveis"

PESQUISADOR: Lia Assumpção

ORIENTADOR: Denise Dantas

INSTITUIÇÃO: Faculdade de Arquitetura e Urbanismo - USP

FINALIDADE: Mestrado

DATA: $07 / 03 / 17$

FINALIDADE DA CONSULTA: Sugestões sobre seleção de amostra e ajustes em questionário.

PARTICIPANTES DA ENTREVISTA: Lúcia Pereira Barroso

Viviana Giampaoli

Laryssa Del Corso Costa

Diego Ribeiro Marcondes

RELATÓRIO ELABORADO POR: Laryssa Del Corso Costa Diego Ribeiro Marcondes 


\section{Introdução}

Com o advento das sociedades capitalistas modernas, e com elas os novos mercados consumidores, os hábitos de consumo da população em geral sofreram uma grande mudança, especialmente a partir dos anos de 1990, no sentido de um consumismo não sustentável e baseado em valores externos aos produtos, e.g., status. Com a rápida evolução tecnológica, bens duráveis passaram a ficar obsoletos mais rapidamente, incentivando um maior consumo, em detrimento do meio ambiente, que sofre com o lixo gerado.

A obsolescência é, de fato, parte inerente do mercantilismo do século XXI, já que os avanços tecnológicos acontecem em uma velocidade nunca antes vista na história da humanidade. Embora algumas empresas fabriquem bens duráveis de qualidade, estes irão inevitavelmente ficar defasados, já que serão rapidamente substituídos por produtos mais modernos. Entretanto, muitas dessas empresas fazem desse comportamento sua forma de negócio, i.e., fabricam produtos planejados para ficarem obsoletos depois de um determinado período de tempo. Esse processo é chamado de obsolescência programada, e de acordo com o Oxford Dictionary ${ }^{1}$, é

"A policy of producing consumer goods that rapidly become obsolete and so require replacing, achieved by frequent changes in design, termination of the supply of spare parts, and the use of non-durable materials."

Nota-se que, portanto, a obsolescência programada pode ser separada em pelo menos três tipos, que são de interesse para o estudo. O primeiro é a obsolescência por estilo. Nesse caso, o consumidor vê a necessidade de adquirir um novo produto com um

\footnotetext{
${ }^{1}$ Disponível em https://en.oxforddictionaries.com/definition/planned_obsolescence. Acesso em 7 de Março de 2017.

${ }^{2}$ Uma política de produzir bens de consumo que ficam obsoletos rapidamente e necessitam ser substituídos, que é implementada a partir de mudanças frequentes no design do produto, do encerramento da produção de peças de manutenção e o uso de materiais não-duráveis (tradução livre).
} 
design mais moderno. Um exemplo é a mudança pelo Inmetro do modelo de tomada padrão no país, que passou a ser de três pinos. Com essa inovação, os consumidores foram obrigados a se adaptar, ou trocando as tomadas de sua casa, ou usando adaptadores.

Um outro tipo interessante é a obsolescência tecnológica. Esta caracteriza-se pelo hábito de o consumidor substituir seu bem durável por outro recentemente lançado no mercado, com tecnologias mais avançadas, embora o seu produto ainda tenha vida útil. Muitos fabricantes planejam com antecedência os próximos produtos que irão lançar, de modo que cada um deles fique defasado em um tempo previamente planejado. Essa é uma prática que se encontra com frequência na indústria de celulares e eletrônicos, em que novas tecnologias são lançadas em curtos períodos de tempo, apenas para tornar o produto atual obsoleto, mas sem tecnologia o bastante para não ficar ultrapassado nos próximos meses.

Por fim, temos a obsolescência por funcionalidade, que ocorre quando o bem deixa de ser funcional. Na maioria das vezes, isso acontece no momento em que o produto quebra e não há conserto para ele, i.e., deixa de ser útil para o consumidor. Essa prática pode ser planejada por uma empresa de várias maneiras. Ela pode, por exemplo, fazer um bem com materiais de baixa qualidade que possuam uma vida útil curta e, ainda, não disponibilizar peças para possíveis manutenções. Uma outra tática é fabricar produtos com prazo de validade.

Embora presente em todo o mundo, e objeto de artigos científicos, notícias e documentários, a obsolescência programada não foi totalmente estudada e entendida, já que, mesmo que sua existência seja conhecida, as empresas não admitem empregála e, portanto, suas características devem ser estudadas a partir dos hábitos dos 
consumidores e suas percepções acerca das muitas dimensões que compõem o conceito de obsolescência programada.

\subsection{Objetivo}

A falta de bibliografia sobre a obsolescência programada, principalmente em Português, leva à necessidade de novas pesquisas para ser melhor entendida, principalmente na sociedade brasileira, onde poucos estudos foram feitos sobre esse assunto.

Para esse fim, o objetivo da pesquisa é identificar as práticas de consumo dos consumidores, observando a relação que eles fazem entre a obsolescência programada e o design.

\section{Descrição do estudo}

O estudo se divide em duas partes, uma qualitativa e outra quantitativa. A parte qualitativa é baseada em entrevistas com profissionais, e pessoas selecionadas, sobre a obsolescência programada e suas relações com o design, além do monitoramento da página do Facebook "Feitos para Quebrar", criada pela pesquisadora para que pessoas comuns compartilhem experiências e ideias sobre os hábitos de consumo e a obsolescência programada.

Essa análise qualitativa é importante pois fornece várias informações sobre hábitos de consumo que podem ser objetos de estudos futuros, mais direcionados e específicos, que abordem características da obsolescência programada inerentes ao consumidor brasileiro, que não são encontradas em consumidores de outras sociedades.

Por outro lado, a análise quantitativa, para a qual a pesquisadora solicitou contribuições do CEA, será feita a partir da aplicação de um questionário com o objetivo de se realizar uma sondagem da população de interesse, com o intuito não de fazer ${ }^{3}$ Disponível em https://www.facebook.com/feitosparaquebrar. Acessado em 7 de Março de 2017. 
inferências sobre tal população e obter conclusões válidas para ela como um todo, mas de observar tendências e casos particulares que possam servir como base para estudos futuros sobre características mais específicas da obsolescência programada e suas particularidades na sociedade brasileira.

\section{Situação do Estudo}

Um questionário preliminar, elaborado pelo responsável do projeto, já está disponível. (Veja Anexo 1)

Inicialmente, espera-se que habitantes da Cidade de São Paulo sejam entrevistados.

Este relatório deve sugerir ajustes necessários no questionário e no plano amostral.

\section{Sugestões do CEA}

\subsection{Questionário:}

Para atender da melhor maneira possível os objetivos da pesquisa, o questionário deve conter questões de múltipla escolha e dissertativas. Há a necessidade de se obter várias informações socioeconômicas do entrevistado, já que, acredita-se, que os hábitos de consumo diferem de uma classe social para outra, além de ser importante poder discriminar os dados obtidos pela aplicação do questionário de acordo com variáveis de interesse.

Nem todas as pessoas querem se identificar. Sugere-se portanto, deixar o campo do nome como não obrigatório. O mesmo vale para qualquer outra variável que o identifique, e.g., RG, CPF, NUSP, pois pode ocorrer de o entrevistado ter receio de que suas respostas sejam tornadas públicas ou não se sinta confortável em se identificar em 
detalhes. Entretanto, é importante identificar cada questionário com um número para posterior checagem da planilha de dados.

Por outro lado, o sexo e a faixa etária, são variáveis imprescindíveis no questionário, já que é conhecido que os hábitos de consumo variam entre os diferentes sexos e faixas etárias. Entretanto, é necessário ou estabelecer a priori as faixas etárias de modo que se obtenha uma boa interpretação dos dados a partir delas, e.g., 13 a 17 anos são os adolescentes e acima de 60 anos são os idosos, ou perguntar as idades das pessoas e separá-las em faixas etárias a posteriori. A determinação das faixas etárias a posteriori é a mais indicada pois possibilita uma futura mudança nas faixas etárias, além de uma análise da idade como variável quantitativa, sem separá-la em categorias.

A profissão e escolaridade do entrevistado podem ser informações importantes, já que desempregados e pessoas de baixa escolaridade, por exemplo, podem possuir hábitos de consumo diferentes. Outras variáveis de interesse são a cidade do entrevistado, embora deva-se deixar claro se a cidade e o estado referem-se ao lugar onde ele nasceu ou onde mora. Tal variável é importante principalmente se o questionário for aplicado pela internet, pois permite localizar geograficamente os hábitos de consumo dos brasileiros.

A renda do entrevistado é uma informação essencial, pois permite diferenciar as classes sociais no que diz respeito aos seus hábitos de consumo. Entretanto, é necessário deixar bem claro sobre qual tipo de renda há interesse. De fato, a renda de um entrevistado pode ser a renda per capita dos habitantes de sua casa ou a renda obtida apenas pelo entrevistado. Assim, o conceito de renda deve ser definido a priori, junto com as suas categorias, e deve estar claro no questionário, para que todos os entrevistados respondam sobre a mesma característica. 
As questões de múltipla escolha devem estar escritas com clareza e de acordo com o público-alvo a que se destinam, i.e., não se deve usar termos técnicos e palavras não conhecidas pelo público-alvo. Suas alternativas não podem ser ambíguas e o entrevistado deve ter a opção de expressar sua opinião de forma mais ampla possível. Em caso de questões de múltipla escolha com mais possibilidades de respostas, deixar uma opção aberta, como "outros", para o entrevistado expressar sua opinião.

Por fim, as questões dissertativas devem ser precisas e completas, de modo que possam ser entendidas, e consequentemente respondidas adequadamente pelo entrevistado. Recomenda-se que o questionário não seja muito extenso, principalmente com muitas questões dissertativas que necessitam de maior atenção e trabalho por parte do entrevistado, pois ele pode ser desestimulado a responder as questões, com o risco de deixá-las incompletas. No Apêndice 1 cada item do questionário é analisado de acordo com as recomendações acima e possíveis melhorias são sugeridas.

\subsection{Amostragem}

Devido à falta de recursos, pessoal e tempo hábil, além do fato de o interesse ser apenas realizar um estudo preliminar que possa, por ventura, oferecer tópicos e levantar temas interessantes para estudos futuros, a amostragem a ser feita será nãoprobabilística, por meio de uma sondagem. Assim, as conclusões a serem tomadas a partir dos dados observados servem apenas como evidências sobre os hábitos de consumo da população-alvo e inferências para toda a população não devem ser tomadas a partir desses dados. De fato, as conclusões poderão servir de diretrizes para estudos futuros mais detalhados.

A primeira parte da sondagem é definir a população-alvo que se pretende estudar. Ela pode ser, por exemplo, os consumidores estudantes da USP, os consumidores da Cidade de São Paulo ou os consumidores brasileiros com acesso ao Facebook. É 
importante que essa população seja definida a priori e que sejam sondados apenas indivíduos dessa população.

Em seguida é necessário determinar a maneira como o questionário será aplicado aos consumidores. Note que, caso a população-alvo seja composta pelos consumidores da Cidade de São Paulo, o questionário não pode ser aplicado pela internet. Da mesma maneira, se o que se deseja é obter alguns dados pela internet e outros pessoalmente, é necessário dividir os entrevistados em dois grupos: os consumidores brasileiros com acesso ao Facebook e os consumidores da Cidade de São Paulo. Tal abordagem seria interessante, pois permitiria obter informações sobre as similaridades entre as duas populações, comparando os hábitos de consumo por localização geográfica.

Determinada a maneira de aplicação do questionário, é preciso estabelecer um tamanho da amostra a ser obtida. Para os fins de uma sondagem, é interessante obter o maior número possível de entrevistados. Pode-se tanto estabelecer a priori a quantidade de entrevistados, ou então estabelecer um período de tempo, e.g., dois meses, nos quais serão aplicados os questionários ao maior número possível de indivíduos da populaçãoalvo. Caso decida-se aplicar questionários pela internet, recomenda-se não estipular a priori o tamanho da amostra e entrevistar o maior número possível de pessoas. Além disso, ao se aplicar o questionário pela internet, deve-se excluir a posteriori as respostas de pessoas fora da população-alvo que por ventura tenham respondido o questionário, e.g., consumidores de outros países.

Por outro lado, caso se decida aplicar o questionário pessoalmente aos consumidores da Cidade de São Paulo, pode-se determinar o tamanho da amostra a priori e então fazer uma sondagem, tomando-se uma amostra proporcional ao número de habitantes de cada região de São Paulo. A Tabela 1 apresenta as subprefeituras da 
Cidade de São Paulo e a população da área sob jurisdição de cada uma, de acordo com o Censo de $2010^{4}$. A Figura 1 mostra o mapa das subprefeituras da Cidade de São Paulo ${ }^{5}$.

Tabela 1 - Número de habitantes da cidade de São Paulo por Subprefeituras.

\begin{tabular}{|l|r|r|}
\hline Subprefeitura & População & Proporção \\
\hline Aricanduva & 267702 & 0,02375 \\
\hline Butantã & 428217 & 0,03799 \\
\hline Campo Limpo & 607105 & 0,05386 \\
\hline Capela do Socorro & 594930 & 0,05278 \\
\hline Casa Verde & 309376 & 0,02745 \\
\hline Cidade Ademar & 410998 & 0,03646 \\
\hline Cidade Tiradentes & 211501 & 0,01876 \\
\hline Ermelino Matarazzo & 207509 & 0,01841 \\
\hline Freguesia do Ó & 407245 & 0,03613 \\
\hline Guaianases & 268508 & 0,02382 \\
\hline Ipiranga & 463804 & 0,04115 \\
\hline Itaim Paulista & 373127 & 0,03310 \\
\hline Itaquera & 523848 & 0,04648 \\
\hline Jabaquara & 223780 & 0,01985 \\
\hline Jaçanã & 291867 & 0,02589 \\
\hline Lapa & 305526 & 0,02711 \\
\hline M'Boi Morim & 563305 & 0,04998 \\
\hline Mooca & 343980 & 0,03052 \\
\hline Parelheiros & 139441 & 0,01237 \\
\hline Penha & 474659 & 0,04211 \\
\hline Perus & 164046 & 0,01455 \\
\hline Pinheiros & 289743 & 0,02571 \\
\hline Pirituba & 437592 & 0,03882 \\
\hline Santana & 324815 & 0,02882 \\
\hline Santo Amaro & 238025 & 0,02112 \\
\hline São Mateus & 426794 & 0,03786 \\
\hline São Miguel & 369496 & 0,03278 \\
\hline Sapopemba & 284524 & 0,02524 \\
\hline Sé & 431106 & 0,03825 \\
\hline Vila Maria/Vila Guilherme & 297713 & 0,02641 \\
\hline Vila Mariana & 344632 & 0,03058 \\
\hline Vila Pudente & 246589 & 0,02188 \\
\hline & & \\
\hline
\end{tabular}

\footnotetext{
${ }^{4}$ Disponível em:

http://www.prefeitura.sp.gov.br/cidade/secretarias/regionais/subprefeituras/dados_demograficos. Acesso em 7 de Março de 2017.

${ }^{5}$ Fonte:

http://www.prefeitura.sp.gov.br/cidade/secretarias/upload/subprefeituras/secretaria/mapasub\%20c or(1).jpg. Acessado em 7 de Março de 2017.
} 


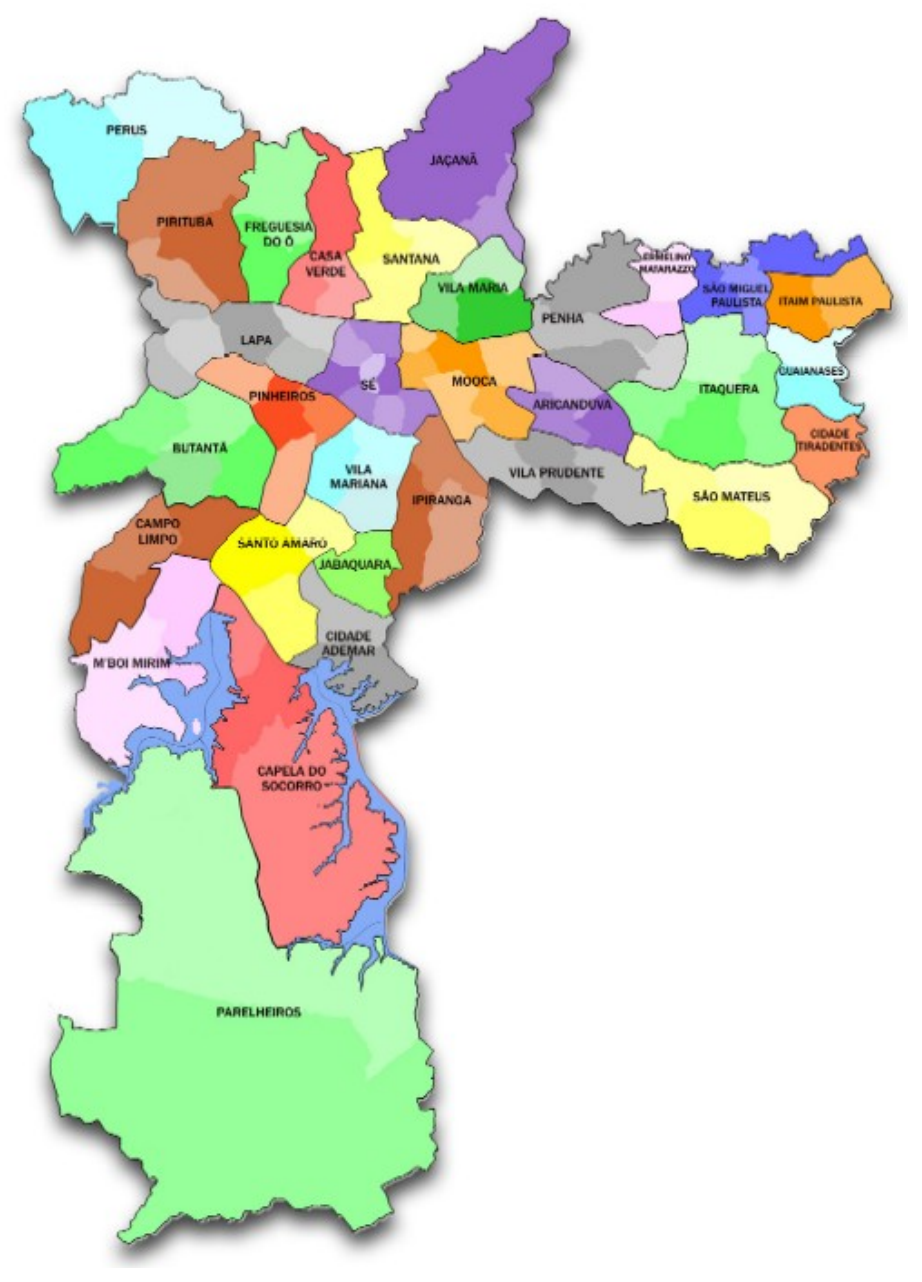

Figura 1 - Mapa da Cidade de São Paulo dividido por subprefeituras.

Fixado um tamanho de amostra $\mathbf{n}$ para cada uma das subprefeituras, sugere-se escolher um lugar bastante movimentado dentro da sua jurisdição, (e.g., estação de metrô, praça, ruas comerciais) e entrevistam-se $\boldsymbol{n} \times \boldsymbol{p}$ pessoas, em que $\boldsymbol{p}$ é a proporção dos habitantes da Cidade de São Paulo que estão sob a jurisdição da subprefeitura escolhida. Por exemplo, para a subprefeitura da Sé, pode-se ir até a Praça da Sé e se entrevistar $\boldsymbol{n} \boldsymbol{x}$ 0,03825 pessoas. Se $\boldsymbol{n}=\mathbf{2 0 0}$, por exemplo, entrevistam-se $200 \times 0,03825=8$ pessoas na Praça da Sé.

Como há muitas subprefeituras, tal processo de sondagem pode ser inviável. Assim, pode-se juntar duas subprefeituras que sejam próximas geograficamente uma da outra e entrevistar pessoas apenas em uma delas, supondo-se que a população que reside nas duas é homogênea. Por exemplo, pode-se juntar as subprefeituras de Pinheiros e Butantã e entrevistar pessoas apenas na estação Pinheiros do Metrô. Assim, se a amostra tem tamanho $n$, recomenda-se entrevistar $n \times(p 1+p 2)=n \times(0,02571$ $+0,03799$ ) pessoas, em que $p 1+p 2=0,02571+0,03799=0,0637$ é a proporção dos 
habitantes da Cidade de São Paulo que residem na região sob a jurisdição da subprefeitura de Pinheiros ou do Butantã. É importante garantir que as pessoas entrevistadas em uma subprefeitura de fato residam em uma área sob sua jurisdição. Portanto, deve-se adicionar um item no questionário que colete informações sobre o bairro do entrevistado.

Pode-se usar outra divisão da Cidade de São Paulo, como por exemplo em zonas Sul, Norte, Leste e Oeste. Entretanto, é necessário notar que a população dentro de cada zona pode não ser homogênea, o que faria com que certa parcela da população não apresentasse representantes na amostra. Mais uma vez, é importante frisar, que tal processo de amostra é não-probabilístico, o que faz com que os resultados obtidos não possam ser estendidos para toda a população-alvo e devam ser usados apenas como diretrizes para estudos mais aprofundados.

\section{Considerações Finais}

A obsolescência programada é um processo inerente ao novo mercado consumidor e deve ser estudado e entendido, a fim de minimizar os seus danos, principalmente os ambientais, conscientizando os consumidores sobre a sua existência.

O estudo descrito acima será uma importante biografia no assunto pois, embora não encerre o tema, investiga-o profundamente, levantando questões de interesse para estudos futuros, e assim, podendo abrir portas para novas pesquisas nessa área. As sugestões do CEA visam melhorar o estudo, a fim de garantir que seus objetivos sejam alcançados através da metodologia definida.

\section{Apêndice 1}

Nesse anexo encontram-se análises e sugestões para questões específicas do questionário do Anexo 1. As questões são reapresentadas, seguidas de sugestões e análises. Não temos sugestões para as questões não apresentadas nesse anexo.

[Sugestão Inicial] Incluir um campo para que cada entrevistado possa ser numerado. Isso irá possibilitar organização para as análises dos dados coletados.

[INSTRUÇÃO] * Required

[Análise] Nem todos os leitores entrevistados entendem a língua inglesa. [Sugestão] Substituir "Required” por "Obrigatório". 


\section{[Questão] Nome *}

[Análise] Nem todas as pessoas querem se identificar.

[Sugestão] Deixar o campo como não obrigatório.

\section{[Questão] Sexo *}

\section{[ ] Feminino}

[ ] Masculino

[ ] Outro

[Análise] Ao escolher perguntar o sexo, as possíveis respostas são feminino ou masculino. No entanto, se a decisão for perguntar pelo gênero, existem diversas respostas possíveis, o que sugere um campo a mais como "outro", deixando ao lado, um campo de preenchimento.

[Sugestão] Gênero:

[ ] Feminino

[ ] Masculino

[ ] Outro:

\section{[Questão] Faixa etária *}

[ ] entre 18 a 29 anos

[ ] entre 30 e 49 anos

[ ] entre 50 e 70 anos

[ ] mais de 70 anos

[Sugestão] É mais recomendável perguntar as idades das pessoas e separá-las em faixas etárias a posteriori. Isso possibilita uma futura mudança nas faixas etárias, além de uma análise da idade como variável quantitativa, sem separá-la em categorias.

[Questão] Profissão (se possível, faça uma breve descrição do seu trabalho no dia a dia)*

[Sugestão] Excluir o que está entre parênteses. A descrição do trabalho do entrevistado parece não contribuir com o tema da pesquisa.

[Questão] Cidade

\section{Estado}


[Análise] Deve-se deixar claro se a cidade e o estado do entrevistado referem-se ao lugar onde ele nasceu ou onde mora. Além disso, como a amostragem será feita por subprefeituras, é importante perguntar o bairro onde o entrevistado mora, para que as respostas possam ser organizadas a posteriori.

[Sugestão] Cidade e Estado onde mora

Bairro onde mora

\section{[Questão] Renda familiar mensal}

[ ] até $R \$ 1.760,00,00$ (2 salários mínimos)

[ ] de $R \$ 1.760,00$ a $R \$ 2.640,00$ (2 a 3 salários mínimos)

[ ] de $R \$ 2.640,00$ a $R \$ 3.520,00$ (3 a 4 salários mínimos)

[ ] de $R \$ 3.520,00$ a $R \$ 4.400,00$ (4 a 5 salários mínimos)

[ ] de $\mathrm{R} \$ 4.400,00$ a $\mathrm{R} \$ 5.280,00$ (5 a 6 salários mínimos)

[ ] de $R \$ 5.280,00$ a $R \$ 6.160,00$ (6 a 7 salários mínimos)

[ ] mais de $R \$ 7.040,00$ (8 salários mínimos)

[ ] Prefiro não declarar

[Análise] Uma renda familiar de 8 salários mínimos em uma família de 10 pessoas é bem diferente de uma renda familiar de 8 salários mínimos em uma família com 2 pessoas, por exemplo: na primeira temos uma renda per capita de um salário mínimo e na segunda temos uma renda per capita de 4 salários mínimos.

[Sugestão] Incluir nova questão perguntando o número de moradores na residência do entrevistado. Assim será possível calcular a renda per capita.

[Questão] De maneira geral, quando seus bens de consumo duráveis apresentam defeitos, você costuma:

[ ] Sempre tentar consertá-los

[ ] Descartá-los e comprar um novo

[Sugestão] Acrescentar a possibilidade de resposta "outro" deixando ao lado, um campo de preenchimento, pois como a pesquisa tem um caráter de sondagem, é importante não restringir as respostas.

[Questão] Sobre práticas de consumo, você costuma:

[ ] Usar os produtos pelo maior tempo possível

[ ] Trocá-los sempre que uma nova versão é colocada no mercado 
[Sugestão] Acrescentar a possibilidade de resposta "outro" deixando ao lado, um campo de preenchimento, pois como a pesquisa tem um caráter de sondagem, é importante não restringir as respostas.

[Questão] A assistência técnica dos produtos é algo importante na decisão de compra?

[ ] Sim

[ ] Não

[Sugestão] Mudar o enunciado para "Na sua opinião, a assistência técnica dos produtos é algo importante na decisão de compra?". Acrescentar a opção "Depende do produto" e "Explique".

[ ] nunca

[ ] às vezes

[ ] frequentemente

[Questão] Costuma comprar produtos usados?

[Sugestão] Alternativas iguais da questão anterior.

[Questão] Como você costuma pagar pelos produtos?

[ ] à vista

[ ] a crédito

[ ] no maior número de parcelas possível

[Sugestão] Substituir as alternativas de resposta por:

[ ] à vista

[ ] a crédito, em poucas parcelas

[ ] a credito, no maior número de parcelas possível

[Questão] Em relação à frase "O que é novo é bom e o que é antigo é ruim" você:

[ ] Concorda totalmente com esta frase

[ ] Concorda parcialmente com esta frase

[ ] Discorda parcialmente com esta frase

[ ] Discorda totalmente com esta frase

[Sugestão] Incluir a alternativa "Não concordo nem discordo" da seguinte forma:

[ ] Concorda totalmente com esta frase

[ ] Concorda parcialmente com esta frase

[ ] Não concordo nem discordo 
[ ] Discorda parcialmente com esta frase

[ ] Discorda totalmente com esta frase

[Questão] Em relação à frase "Se um produto é barato pode durar pouco, se é caro deve durar muito" você:

[ ] Concorda totalmente com esta frase

[ ] Concorda parcialmente com esta frase

[ ] Discorda parcialmente com esta frase

[ ] Discorda totalmente com esta frase

[Sugestão] Mesma sugestão da questão anterior.

[Questão] Considerando suas últimas compras de bens de consumo duráveis, você ficou satisfeito(a) com o valor que foi pago e o tempo que ele durou?

[ ] Sim

[ ] Não

[Sugestão] Incluir a alternativa "Não sei".

[Questão] Você identifica esta estratégia/prática no seu cotidiano?

[ ] Sim

[ ] Não

[Sugestão] Incluir a alternativa "Não sei".

[Questão] A que parte das empresas você associaria esta estratégia/prática?

[ ] Departamento de propaganda

[ ] Departamento de design dos produtos

[ ] Departamento financeiro

[ ]

[Sugestão] Incluir a alternativa "Não sei".

[Questão] Essa prática (obsolescência programada) incomoda você de alguma maneira?

[ ] Sim

[ ] Não

[Sugestão] Incluir a alternativa "Não sei". 


\section{Anexo 2}

Relatório com os dados levantados no questionário 
Título: Apresentação dos dados coletados com o questionário "Pesquisa sobre práticas de consumo de bens de consumo duráveis"

Relatório elaborado por: Eduardo Lazzari

Data: $14 / 08 / 2017$

\section{Sumário}

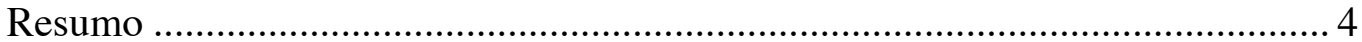

Impressões Gerais Análise Inicial - Obsolescência Programada ........................ 4

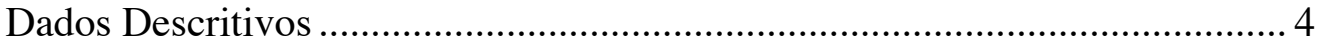

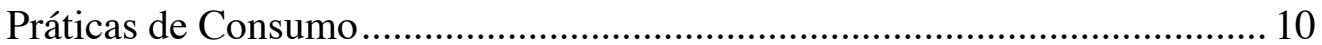

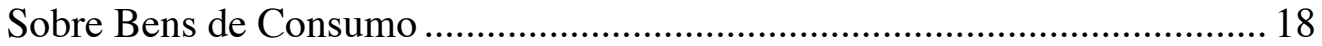

Sobre o Tema de Obsolescência Programada ............................................... 25

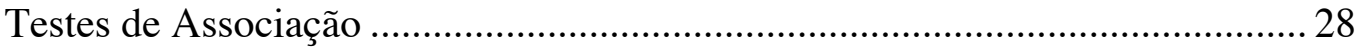

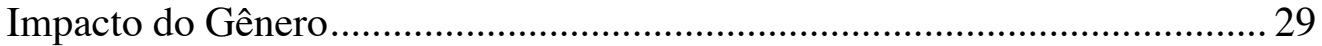

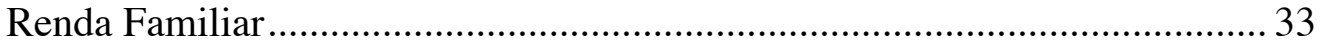

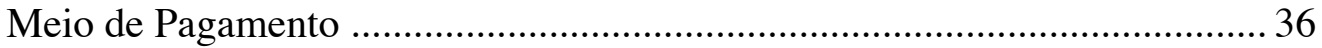

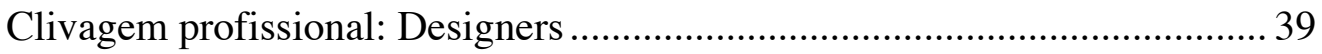

Clivagem do Motivo por Ter Comprado o Último Produto .......................... 40

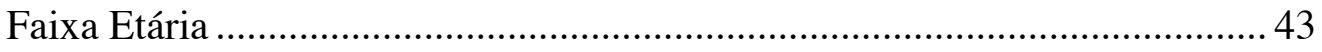

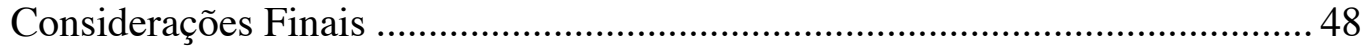

\section{Sumário de Gráficos}

Gráfico 1 - Distribuição de Respondentes por Gênero ....................................... 5

Gráfico 2 - Distribuição Etária.......................................................................... 5

Gráfico 3 - Distribuição de Escolaridade............................................................... 6

Gráfico 4 - Distribuição Estadual ...................................................................... 7

Gráfico 5 - Distribuição dos Residentes do Estado de São Paulo ......................... 8

Gráfico 6 - Distribuição de Bairros dos Residentes da Cidade de São Paulo....... 8

Gráfico 7 - Nuvem de Palavras das Profissões ...................................................... 9

Gráfico 8 - Reações a Defeitos nos Produtos ...................................................... 10

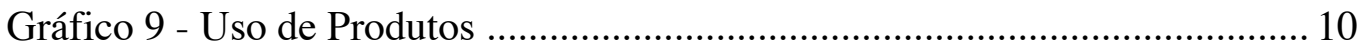

Gráfico 10 - Importância da Durabilidade do Produto na Compra...................... 11 
Gráfico 11 - Importância da Assistência Técnica .............................................. 11

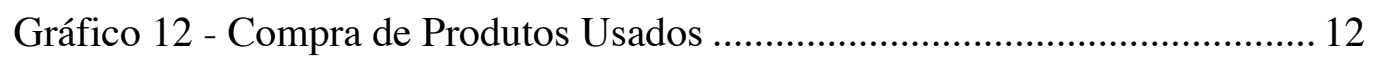

Gráfico 13 - Produtos Usados Adquiridos ....................................................... 12

Gráfico 14 - Aquisição Por Ser Lançamento ..................................................... 13

Gráfico 15 - Tipos de Produtos Adquiridos por Serem Lançamentos ................ 14

Gráfico 16 - Atrativos para comprar um Lançamento .......................................... 14

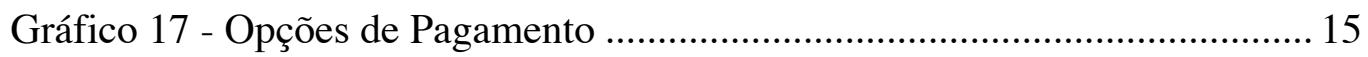

Gráfico 18 - Concordância com "O que é novo é bom" ..................................... 16

Gráfico 19 - Concordância com "Se um produto é caro, deve durar muito" ....... 16

Gráfico 20 - Satisfação com o Valor Pago ......................................................... 17

Gráfico 21 - Satisfação com o Tempo que o Produto Durou............................... 17

Gráfico 22 - Último Bem de Consumo Adquirido .............................................. 18

Gráfico 23 - Nuvem de Palavras Especificando o Último Produto Adquirido... 18

Gráfico 24 - Que Tipo de Produto foi Adquirido .............................................. 19

Gráfico 25 - Motivo da Compra ...................................................................... 19

Gráfico 26 - Satisfação com a Durabilidade do Produto .................................... 20

Gráfico 27 - Meses de Duração do Produto....................................................... 21

Gráfico 28 - Quantos Meses o Produto Deveria Ter Durado ............................. 21

Gráfico 29 - O que teriam feito se o produto não tivesse quebrado ................... 22

Gráfico 30 - Tentativas de Conserto ................................................................. 22

Gráfico 31 - Motivos pelo Fracasso no Conserto ............................................... 22

Gráfico 32 - Destino do Produto Quebrado ....................................................... 23

Gráfico 33 - Nuvem de Palavras do Produto Trocado com Maior Frequência.. 23

Gráfico 34 - Nuvem de Palavras com o Motivo de Troca do Produto ............... 24

Gráfico 35 - Nuvem de Palavras dos Produtos Mais Antigos em Uso ............... 24

Gráfico 36 - Distribuição do Tempo de Uso dos Produtos Mais Antigos .......... 25

Gráfico 37 - Conhecimento sobre o tema Obsolescência Programada............... 26

Gráfico 38 - Reconhecimento de Obsolescência Programada ........................... 26

Gráfico 39 - Nuvem de Palavras Produtos que a Obsolescência Programa seria Percebida 27

Gráfico 40 - Setores Empresariais Associados à Prática …................................ 27

Gráfico 41 - Incômodo com a Prática ................................................................ 28

Gráfico 42 - Associação Gênero e Relevância Assistência Técnica .................. 29

Gráfico 43 - Associação Gênero e Aquisição de Produtos Usados .................... 30

Gráfico 44 - Associação Gênero e Forma de Pagamento .................................... 31

Gráfico 45 - Associação Gênero e Concordância com "Se é caro, deve durar muito" 31

Gráfico 46 - Associação Gênero e Satisfação Durabilidade do Produto ............. 31

Gráfico 47 - Associação Gênero e Conhecimento Obsolescência Programada . 32 
Gráfico 48 - Associação Gênero e Compra de Produto Após Quebra 32

Gráfico 49 - Associação Renda Familiar e Relevância Assistência Técnica ..... 33

Gráfico 50 - Associação Renda Familiar e Aquisição Produtos Usados ............ 34

Gráfico 51 - Associação Renda Familiar e Forma de Pagamento ....................... 34

Gráfico 52 - Associação Renda Familiar e Concordância "Se é caro, deve durar muito" 35

Gráfico 53 - Associação Renda Familiar e Satisfação Durabilidade Produto .... 35

Gráfico 54 - Associação Renda Familiar e Conhecimento Obsolescência Programada 36

Gráfico 55 - Associação Forma de Pagamento e Relevância Assistência Técnica 36

Gráfico 56 - Associação Meio de Pagamento e Compra de Produtos Usados ... 37

Gráfico 57 - Associação Forma de Pagamento e Concordância com "Se é caro, deve durar muito"

Gráfico 58 - Associação Forma de Pagamento e Satisfação com a Durabilidade do Produto 38

Gráfico 59 - Associação Meio de Pagamento e Conhecimento "Obsolescência Programada" 38

Gráfico 60 - Importância Assistência Técnica por Faixa Etária ........................ 43

Gráfico 61 - Concordância com "Se é caro, deve durar muito" por Faixa Etária44

Gráfico 62 - Desejo de maior durabilidade do produto por Faixa Etária ............ 44

Gráfico 63 - Consideração da Durabilidade no Ato da Compra por Faixa Etária 45

Gráfico 64 - Meio de Pagamento por Faixa Etária ........................................... 46

Gráfico 65 - Aquisição de um novo produto por Faixa Etária............................ 46

Gráfico 66 - Associação Satisfação com a Durabilidade em Função do Valor por Faixa Etária 46

Gráfico 67 - Conhecimento do Termo Obsolescência Programada por Faixa Etária. 47

Gráfico 68 - Compra de Produtos Usados por Faixa Etária 47

\section{Sumário de Tabelas}

Tabela 1 - Distribuição de Renda ................................................................... 7

Tabela 2 - Distribuição de Profissões ................................................................. 39

Tabela 3 - Teste de Associação entre Profissão e Conhecimento de Obsolescência Programada 39

Tabela 4 - Associação Bem Adquirido e Motivo para Aquisição ...................... 41

Tabela 5 - Associação Forma de Pagamento e Motivo pela Aquisição.............. 43 


\section{Resumo}

O presente trabalho deseja apresentar os dados coletados de questionário aplicado e respondido por 444 pessoas, referente ao tema de obsolescência programada. Seu intuito é eminentemente descritivo e exploratório.

Em geral, pode-se afirmar que a população é majoritariamente feminina, altamente escolarizada e com alto poder aquisitivo. De modo que recortes dessas variáveis para a explicação de percepções de interesse será dificultada, ou seja, será problemática uma inferência de que mulheres seriam mais propensas a $X$ do que homens, por exemplo. Essas características devem refletir o meio eletrônico no qual foi difundido esse questionário. Além disso, a grande quantidade de respondentes designers e professores provavelmente aumentou o conhecimento prévio em relação ao tema.

No mais, as práticas de consumo apontadas indicam uma população que tenta usar seus produtos pelo maior tempo possível, os adquirem por meio de um pequeno número de parcelas e raramente o fazem por ser um lançamento. Sobre os bens de consumo, os bens mais visados são os smartphones, de modo que os respondentes gostariam que seus últimos produtos tivessem durado mais, com altíssimas expectativas de durabilidade. Por fim, há um amplo conhecimento do termo "obsolescência programada", tal prática os incomoda e a associam ao setor financeiro, que visaria o lucro.

Ao final deste trabalho, apresentamos uma série de testes de associação preliminares. Com eles, encontramos que gênero está associado ao meio de pagamento dos respondentes e ao conhecimento do termo "obsolescência programada". Renda familiar está associada à importância da assistência técnica. O meio de pagamento parcelado ou à vista - está associado à importância da assistência técnica e ao conhecimento do termo "obsolescência programada". Por fim, a faixa etária do respondente está associada à importância da assistência técnica no momento da compra, assim como da durabilidade, à concordância com a frase "se é caro, deve durar muito" e meio de pagamento.

\section{Impressões Gerais Análise Inicial - Obsolescência Programada}

\section{Dados Descritivos}

O presente trabalho se debruça sobre os hábitos de consumo de população de 444 pessoas que responderam ao questionário pertinente ao tema na plataforma do Google Forms, durante o período de 29 de abril até 06 de maio de 2017. Os dados foram tabulados, tratados e analisados na plataforma $\mathrm{R}$ (versão 3.3.3) e aqui apresentam-se seus resultados. $\mathrm{O}$ enfoque aqui é eminentemente descritivo e exploratório. Comecemos 
com o recorte de gênero. A população é majoritariamente feminina, $70 \%$ mais precisamente.

\section{Gráfico 1 - Distribuição de Respondentes por Gênero}

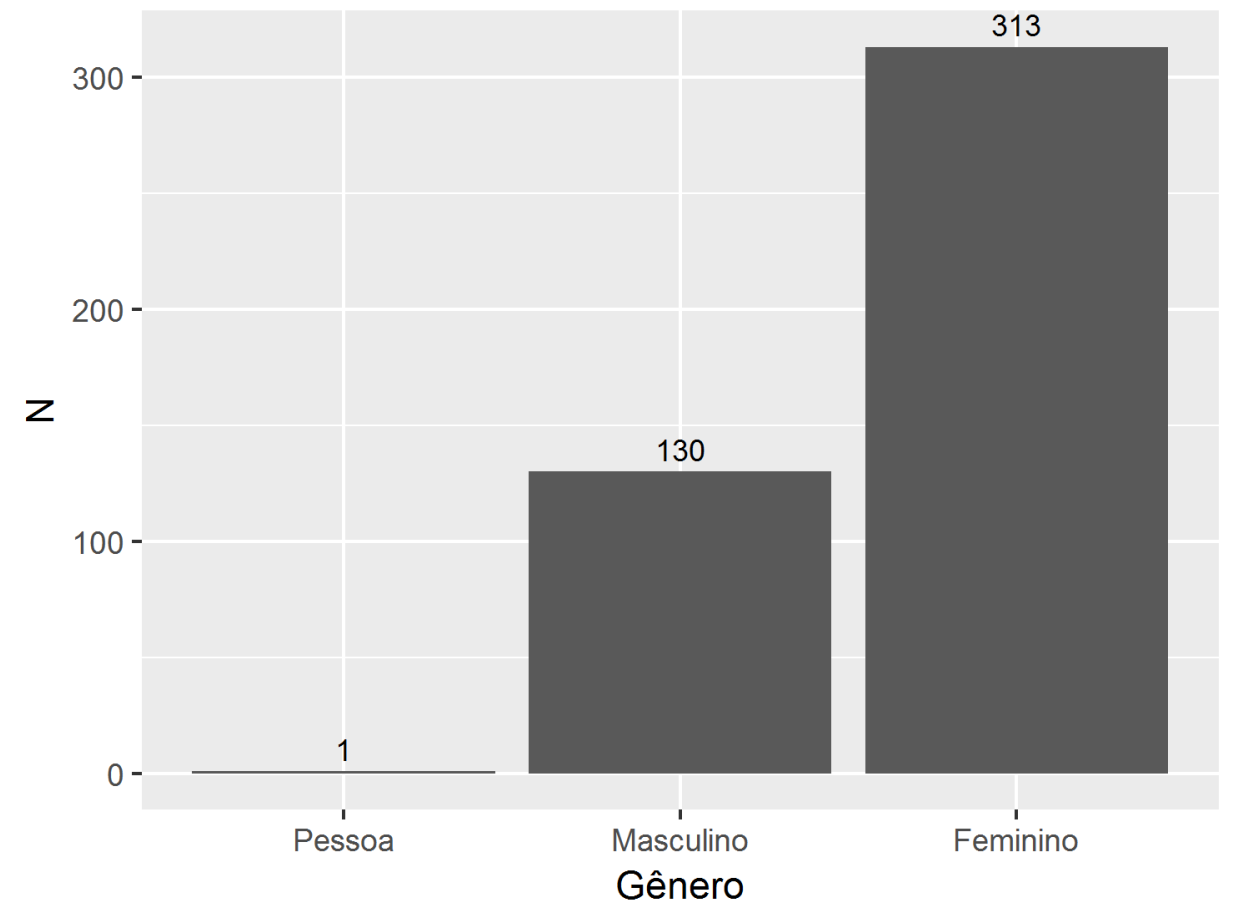

Em seguida apresentamos a distribuição etária dos participantes da pesquisa. $\mathrm{O}$ gráfico abaixo é a curva de densidade das respostas coletadas, de modo que no eixo horizontal indicamos a idade indicada pelo respondente, enquanto que no eixo vertical apresenta-se a proporção de pessoas que se enquadraram no referido ponto do eixo horizontal, ou seja, a porcentagem de pessoas que tinham 40 anos na amostra, por exemplo. A idade média da população aqui analisada é de 40,55 anos.

\section{Gráfico 2 - Distribuição Etária}




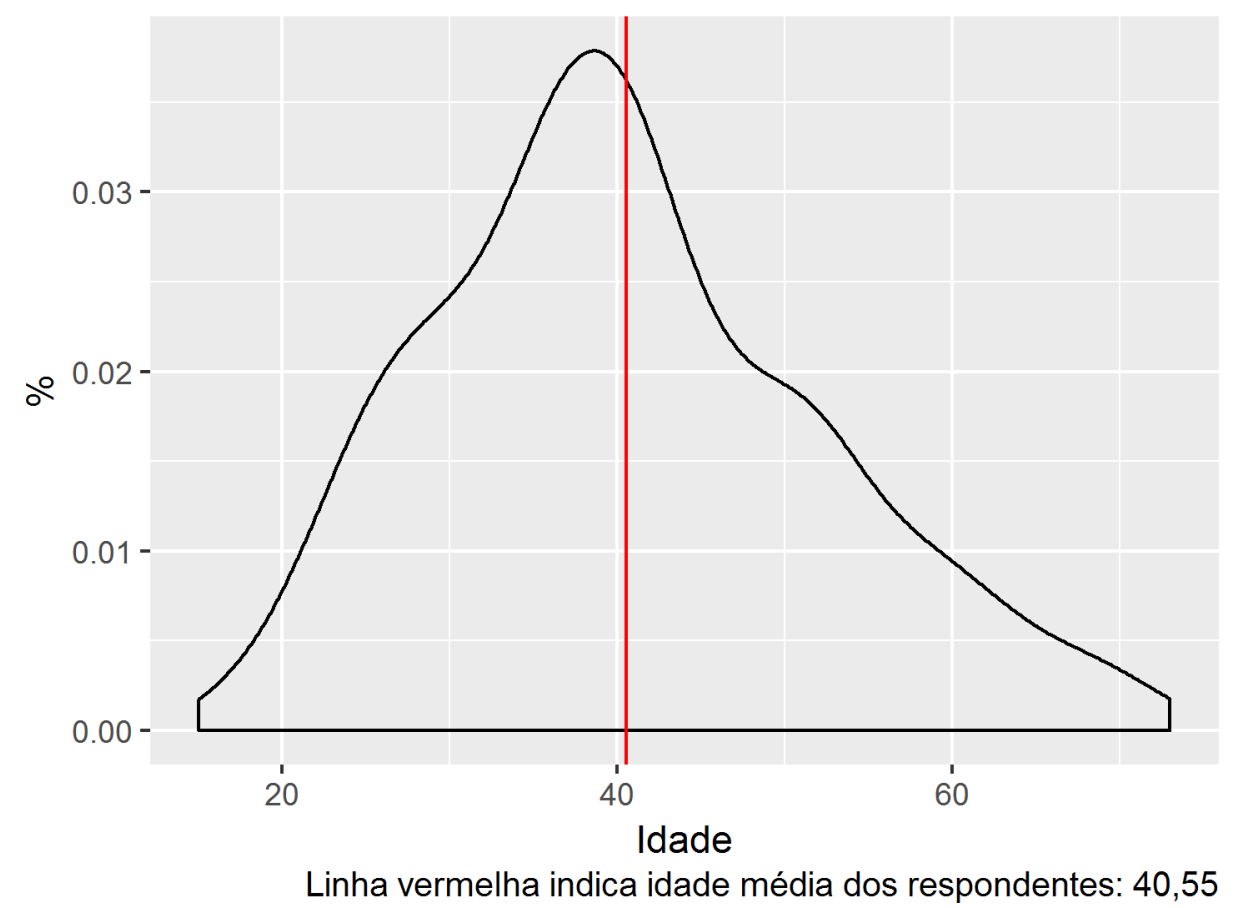

Os dois gráficos abaixo indicam duas características marcantes da população que, como se poderá ver, se diferencia consideravelmente da população brasileira. Afinal, os participantes da pesquisa são altamente escolarizados e com alto poder aquisitivo.

\section{Gráfico 3 - Distribuição de Escolaridade}

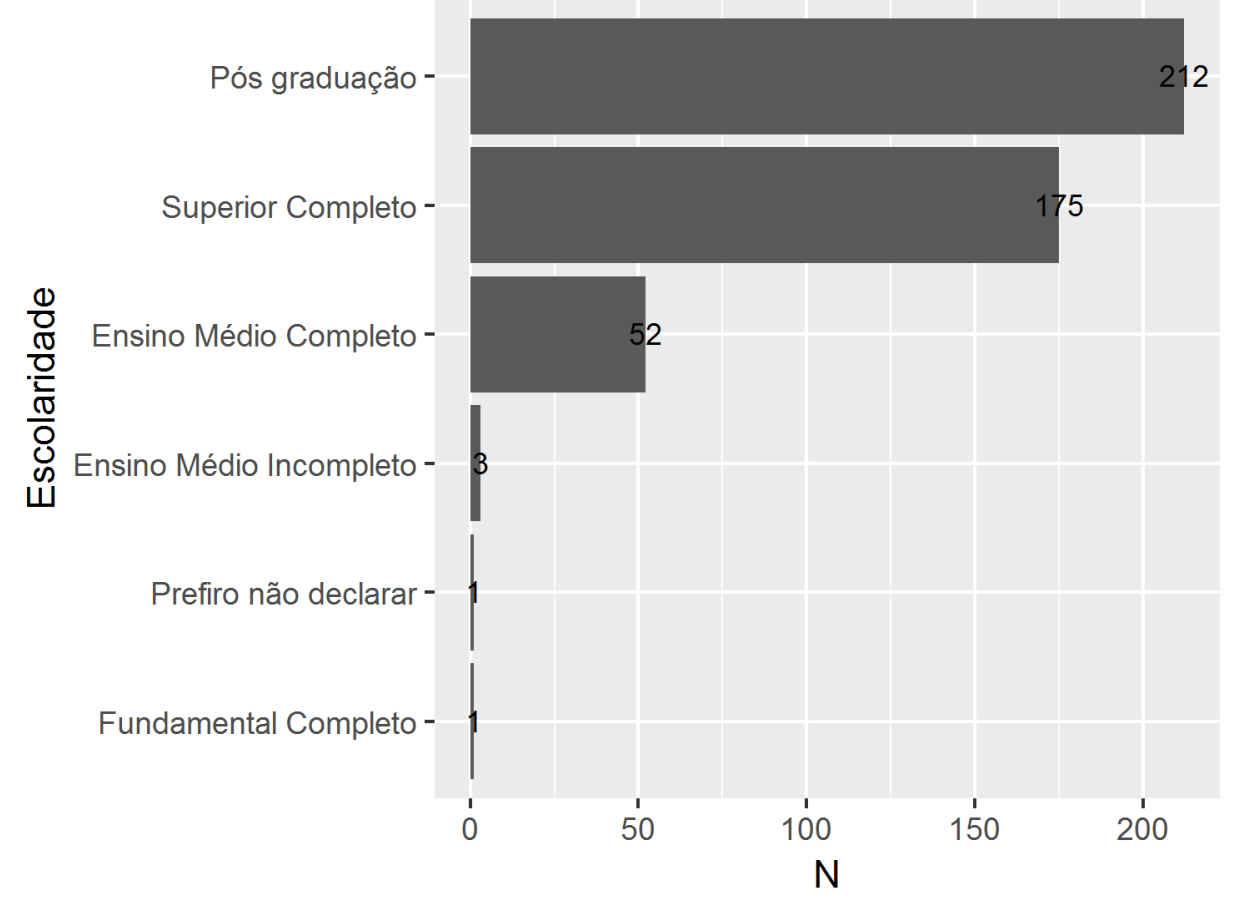

Especificamente, $87 \%$ tem pós-graduação ou ensino superior completo e a categoria de renda com a maior quantidade de respondentes é a de que ganha mais de 
7 salários mínimos, mensalmente. Considerando as duas faixas de renda mais altas, isto é, entre todos aqueles que recebem ao menos seis salários mínimos, 52\%, aproximadamente, se concentram nessas duas faixas. Provavelmente, o fato desses dados terem sido coletados em meio eletrônico contribuiu para um perfil altamente escolarizado e rico.

Tabela 1 - Distribuição de Renda

\begin{tabular}{|c|c|}
\hline Renda Familiar & $\mathrm{N}$ \\
\hline Até R\$ 1.076,20 (1 salário mínimo) & 9 \\
\hline De R\$ 1.076,20 a R\$ 2.152,40 (1 a 2 salários mínimos) & 16 \\
\hline De R\$ 2.152,40 a R\$ 3.228,60 (2 a 3 salários mínimos) & 38 \\
\hline De $\mathrm{R} \$ 3.228,60$ a $\mathrm{R} \$ 4.304,80$ (3 a 4 salários mínimos) & 42 \\
\hline De $\mathrm{R} \$ 4.304,80$ a $\mathrm{R} \$ 5.381,00$ (4 a 5 salários mínimos) & 40 \\
\hline De R\$ 5.381,00 a R\$ 6.457,20 (5 a 6 salários mínimos) & 32 \\
\hline De $\mathrm{R} \$ 6.457,20$ a $\mathrm{R} \$ 7.533,40$ (6 a 7 salários mínimos) & 41 \\
\hline Mais de $\mathrm{R} \$ \mathrm{R} \$ 7.533,40$ (7 salários mínimos) & 191 \\
\hline Prefiro não declarar & 35 \\
\hline Total & 444 \\
\hline
\end{tabular}

Além disso, os respondentes se concentram, especialmente, no estado de São Paulo, com $78 \%$ deles situados naquele estado. Desses, $76 \%$ estão na cidade de São Paulo, desses, os respondentes estão concentrados nos bairros de Pinheiros, Lapa, Sé, Butantã e Vila Mariana, já indicando o perfil da população, isto é, indicando que os respondentes têm alto poder aquisitivo, como se disse acima.

\section{Gráfico 4 - Distribuição Estadual}




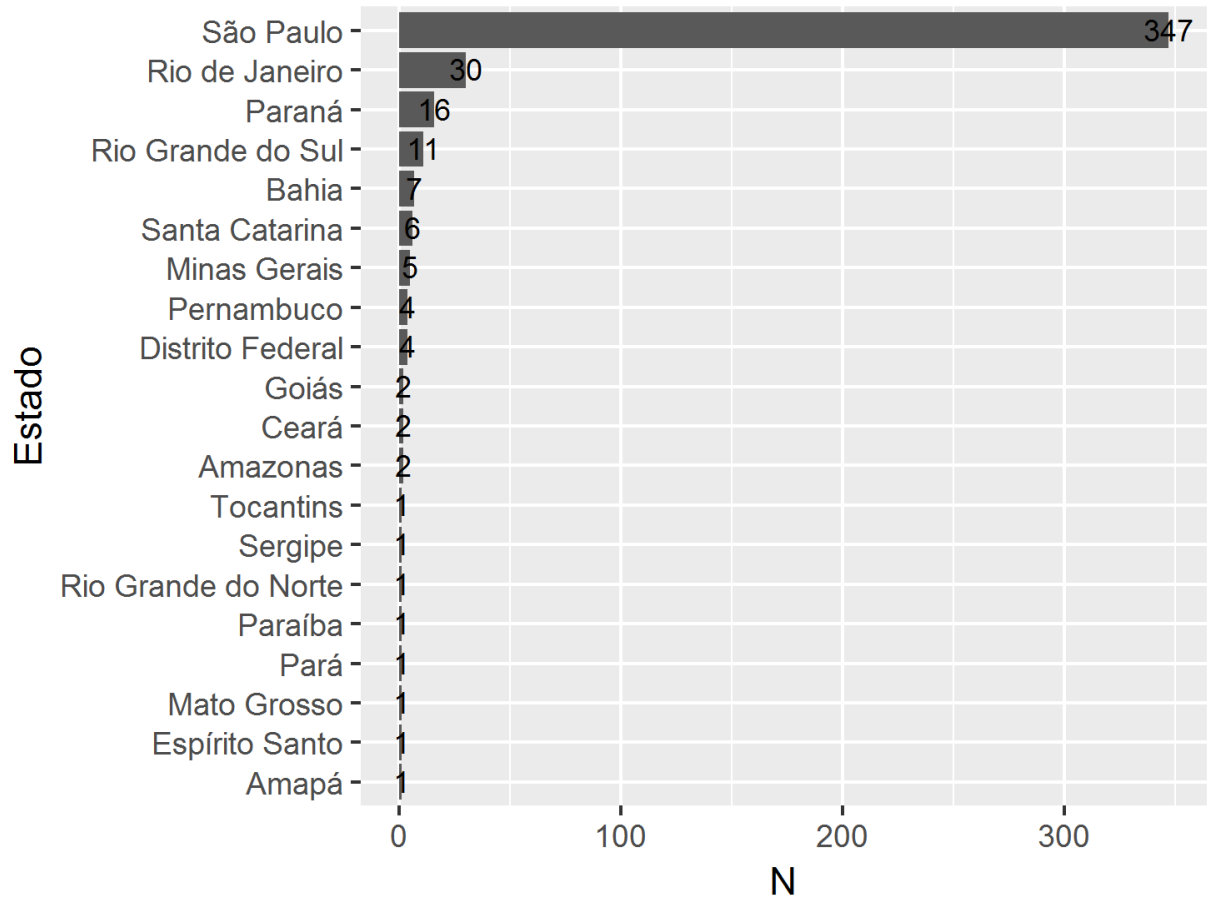

Gráfico 5 - Distribuição dos Residentes do Estado de São Paulo

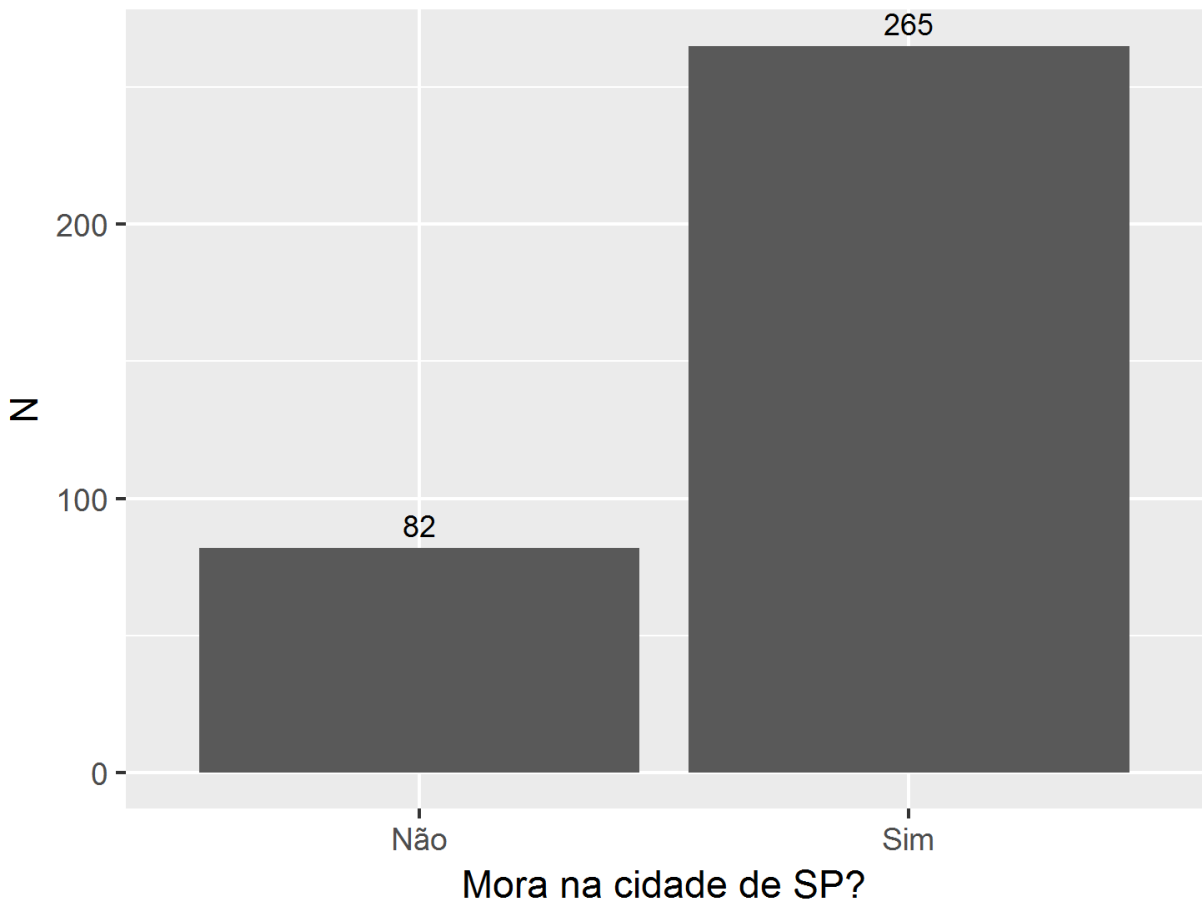

Gráfico 6 - Distribuição de Bairros dos Residentes da Cidade de São Paulo 


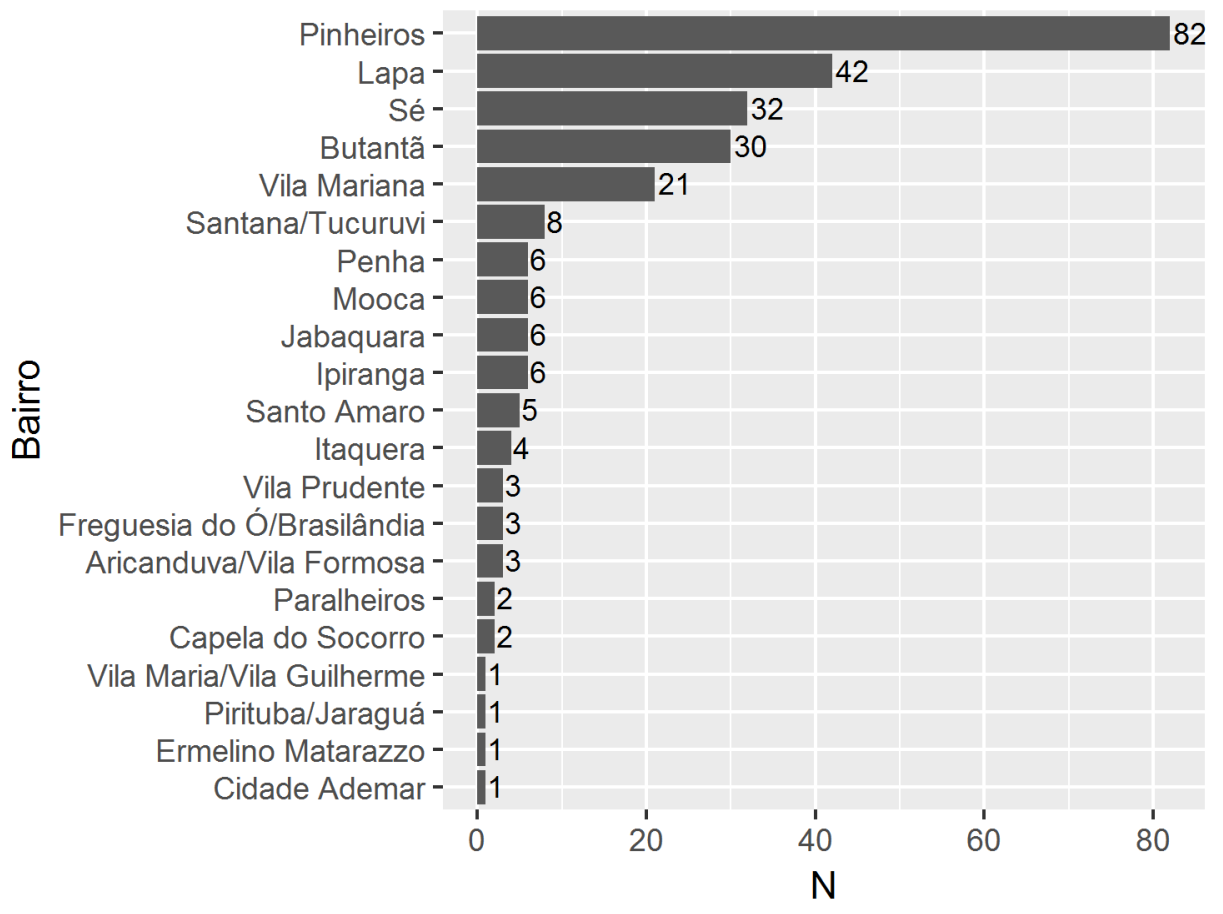

Por fim, é possível observar que as principais profissões são: professor, designer e jornalista. Em resumo, a população que participou da pesquisa é altamente escolarizada, com alto poder aquisitivo e feminina, de modo que as conclusões derivadas dessa pesquisa não podem ser derivadas para o conjunto da sociedade brasileira ou paulista, em que pese a grande importância dos respondentes daquele estado no estudo e a expectativa de que este estudo possui uma intenção estritamente exploratório, constituindo apenas uma sondagem.

\section{Gráfico 7 - Nuvem de Palavras das Profissões ${ }^{1}$}

\footnotetext{
${ }^{1}$ Ainda que visualmente interessante, nuvens de palavras não são tipicamente incluídas em
} trabalhos acadêmicos. Aqui, maior o tamanho da palavra, maior a quantidade de vezes que ela é citada. 


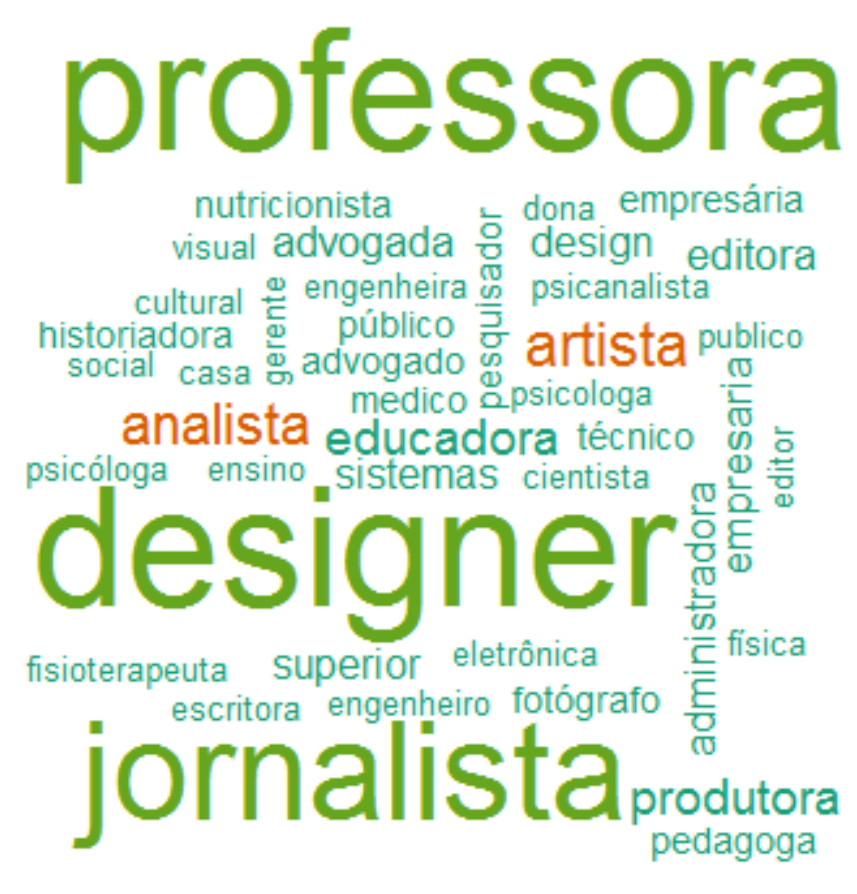

\section{Práticas de Consumo}

Quando os produtos dos respondentes apresentam defeitos, $83 \%$ afirmam que tentam consertá-los.

\section{Gráfico 8 - Reações a Defeitos nos Produtos}

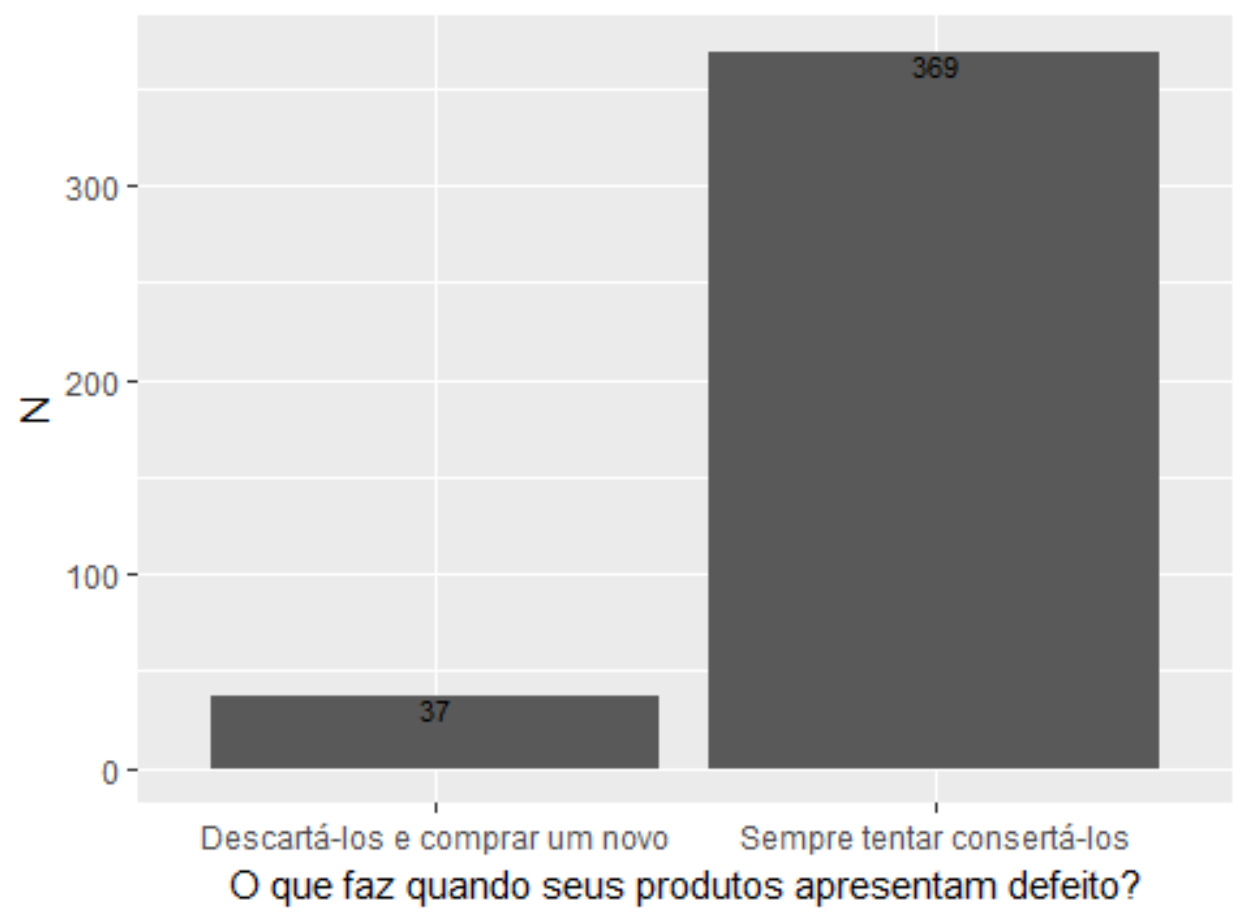

Ao todo, 432 respondentes afirmam usar o produto pelo maior tempo possível.

\section{Gráfico 9 - Uso de Produtos}




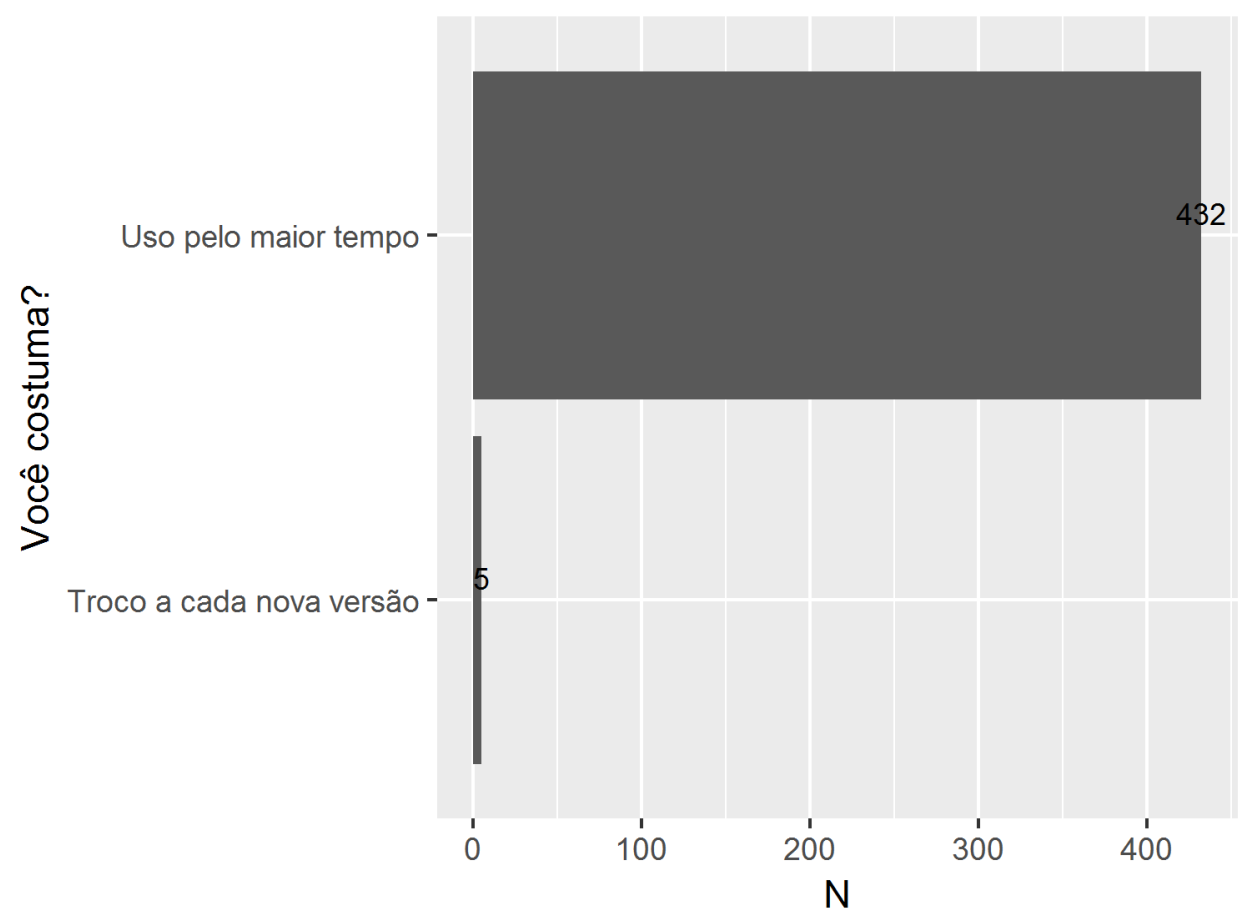

Segundo dados coletados, $76 \%$ consideram a durabilidade do produto no momento da compra.

\section{Gráfico 10 - Importância da Durabilidade do Produto na Compra}

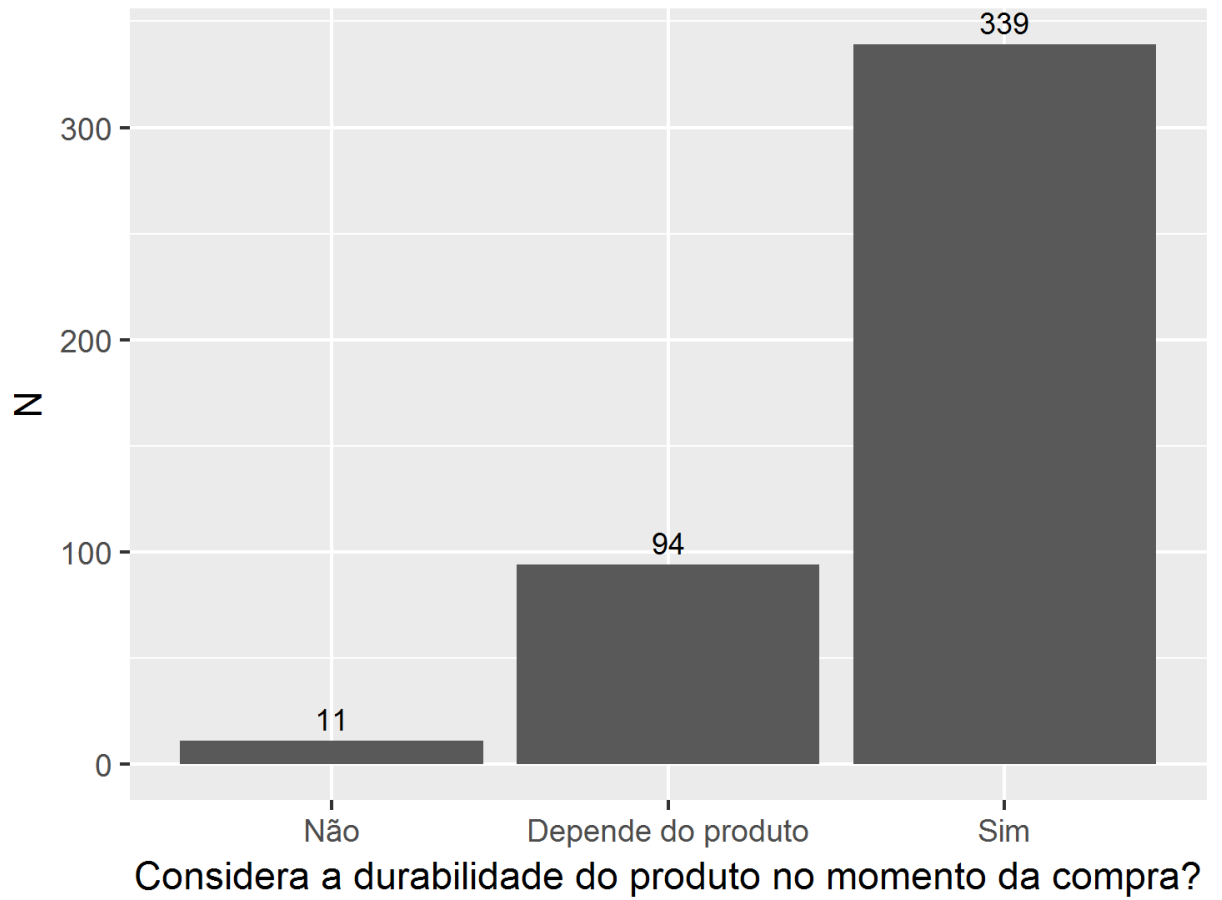

Interessante notar que 56\% acham a assistência técnica importante na hora da compra, de modo que a assistência técnica é menos importante que a durabilidade do produto a depender do produto adquirido.

\section{Gráfico 11 - Importância da Assistência Técnica}




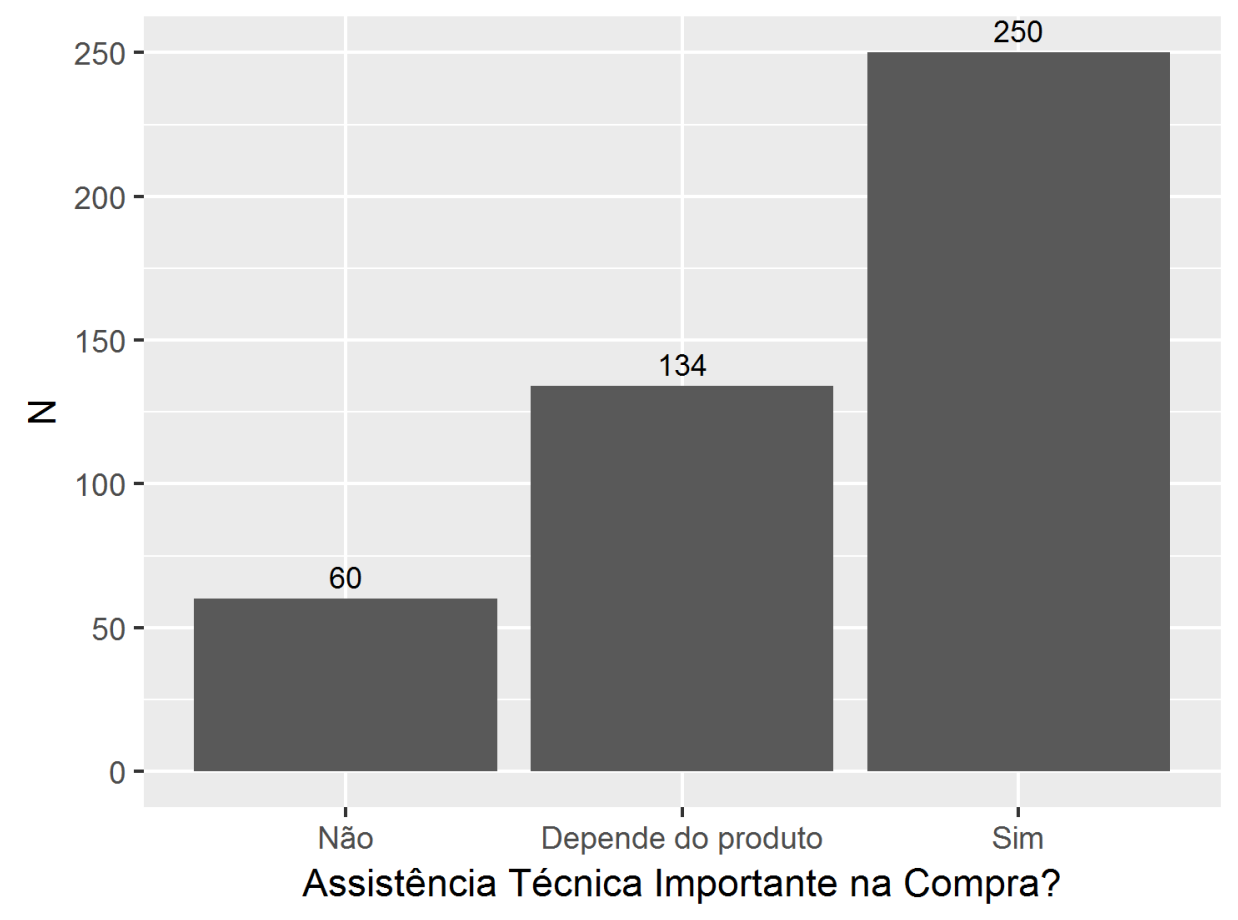

Gráfico 12 - Compra de Produtos Usados

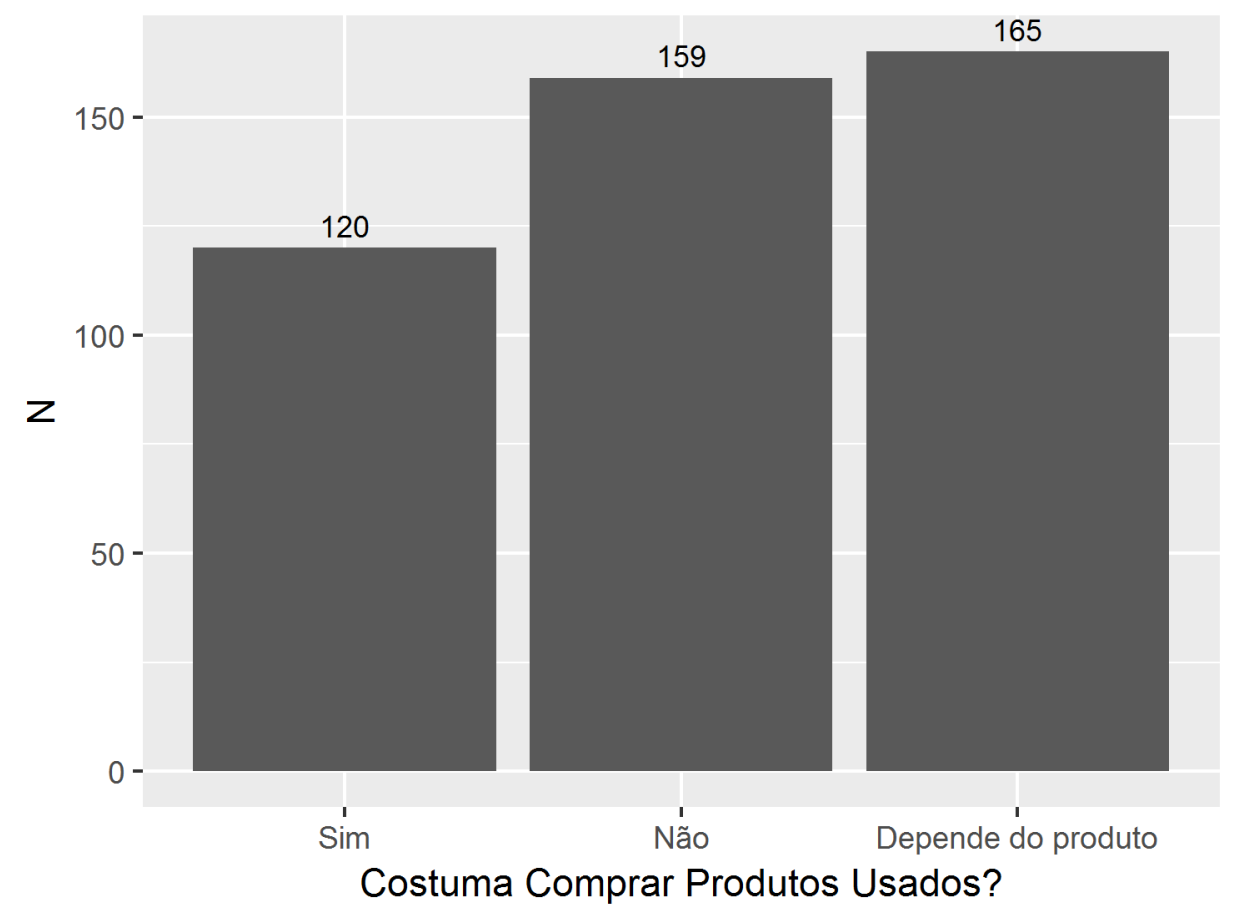

Enquanto que a compra de produtos usados é feita por uma minoria da população, apenas 120 (27\%) afirmam que compram produtos usados, esse tipo de produto só é adquirido, a depender do produto, para $37 \%$ dos respondentes.

Carros e eletrodomésticos são os produtos mais amplamente adquiridos de segunda mão, enquanto que eletrônicos dificilmente são adquiridos dessa maneira.

\section{Gráfico 13 - Produtos Usados Adquiridos}




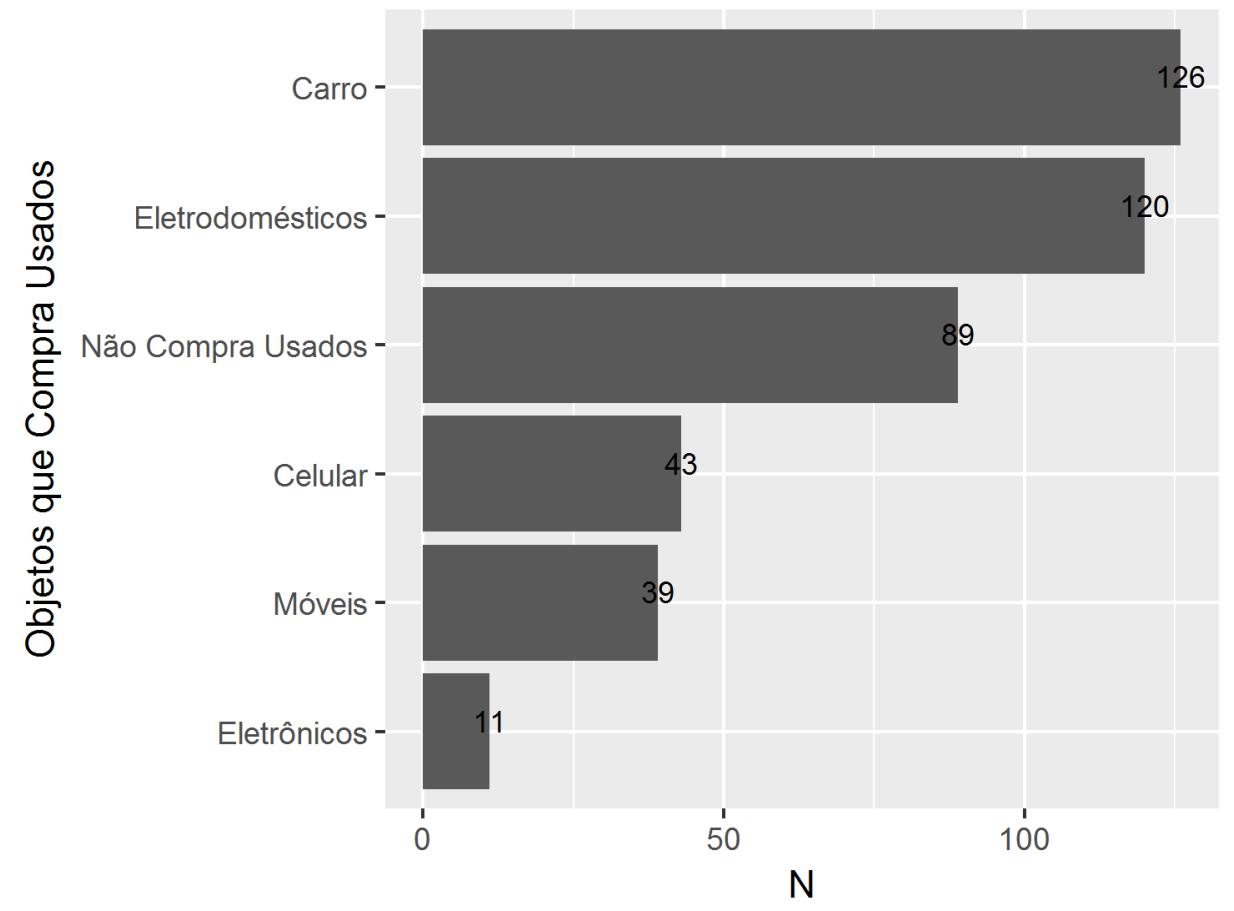

Há uma alta rejeição na aquisição de produtos apenas por serem lançamentos, $402(90 \%)$ respondentes afirmam que não compram um produto apenas por terem sido lançados no mercado há pouco tempo. No reduzido grupo daqueles que podem comprar um produto apenas por ser lançamento, o produto mais amplamente adquirido é o celular, denotando uma característica elementar do produto e eventual status associado a ele. No caso de compra por essa característica, avanço tecnológico é o principal atrativo.

\section{Gráfico 14 - Aquisição Por Ser Lançamento}




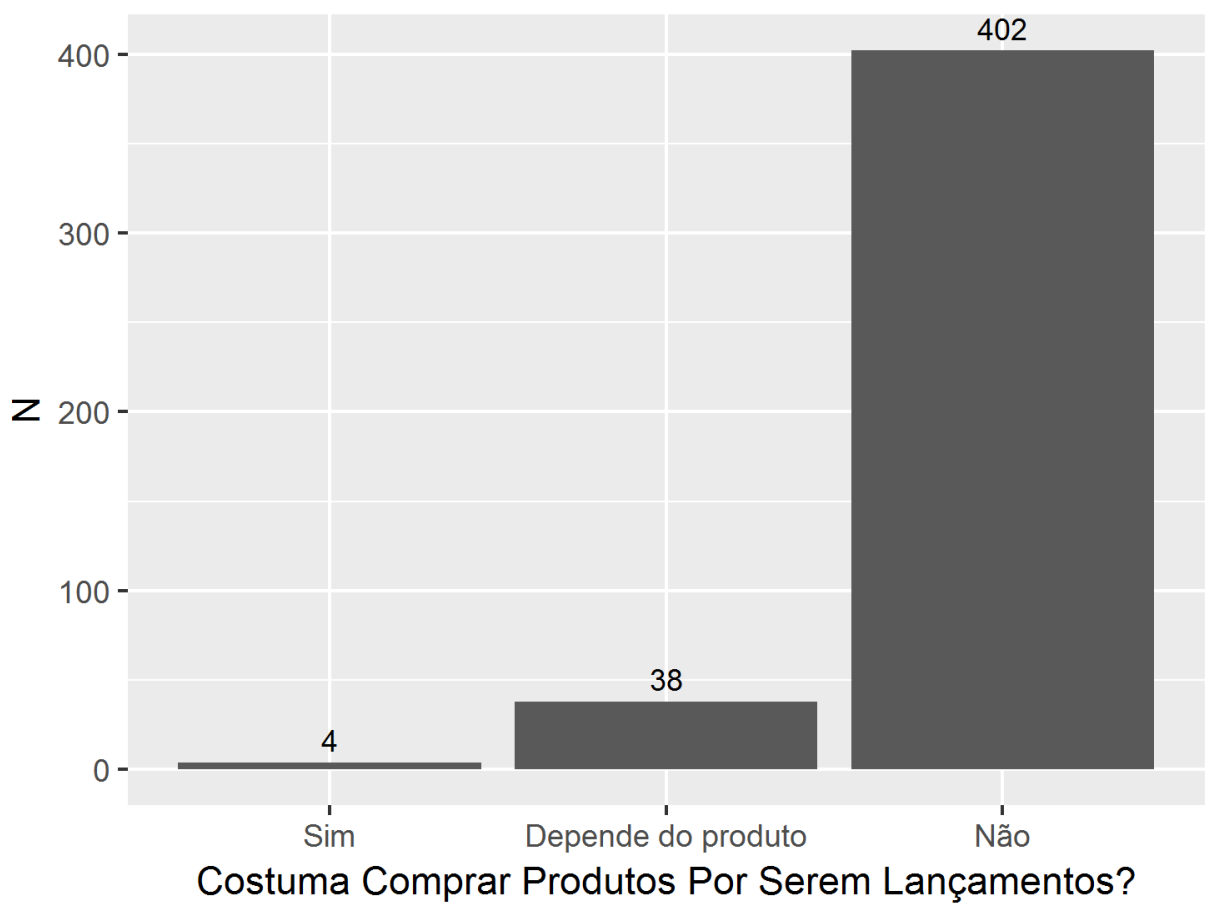

Gráfico 15 - Tipos de Produtos Adquiridos por Serem Lançamentos

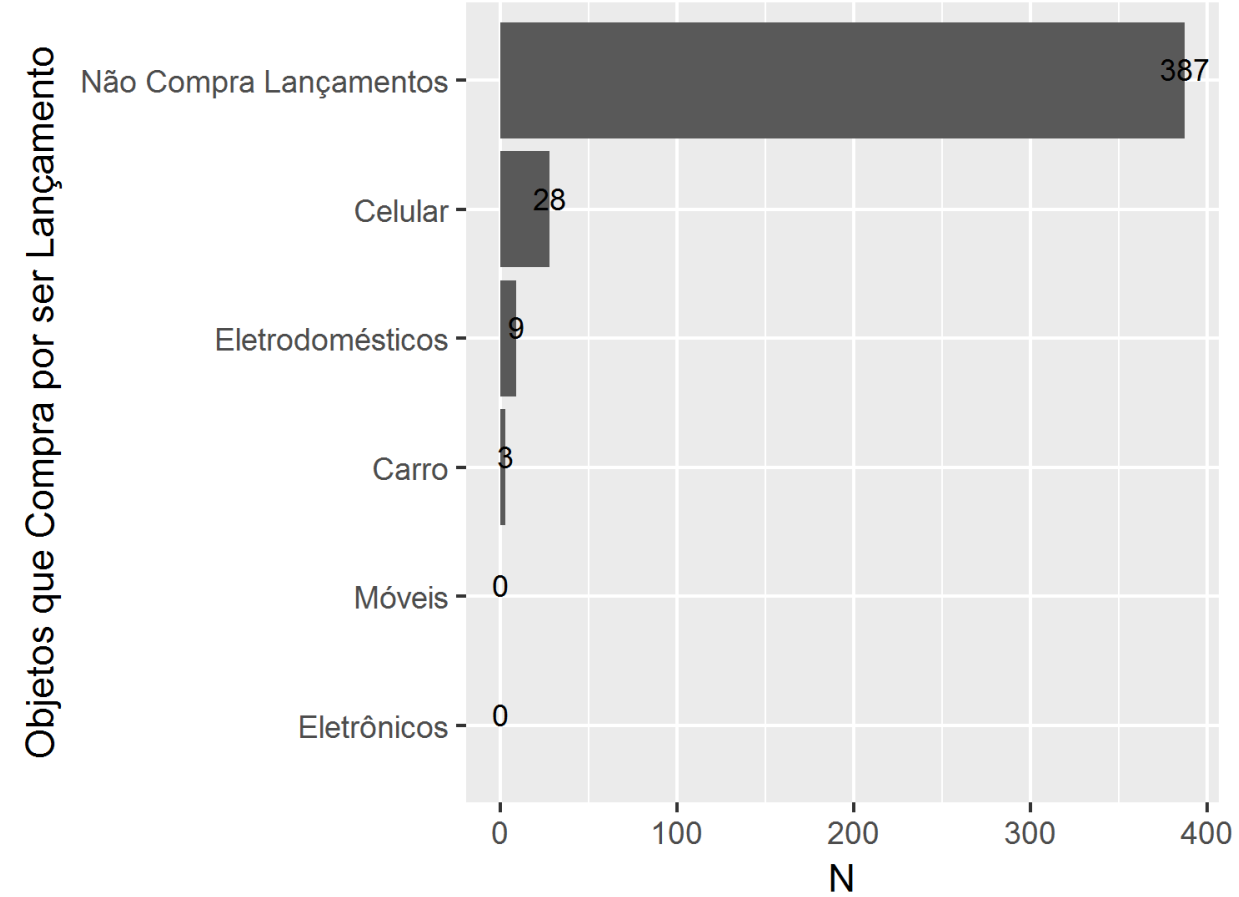

Gráfico 16 - Atrativos para comprar um Lançamento 


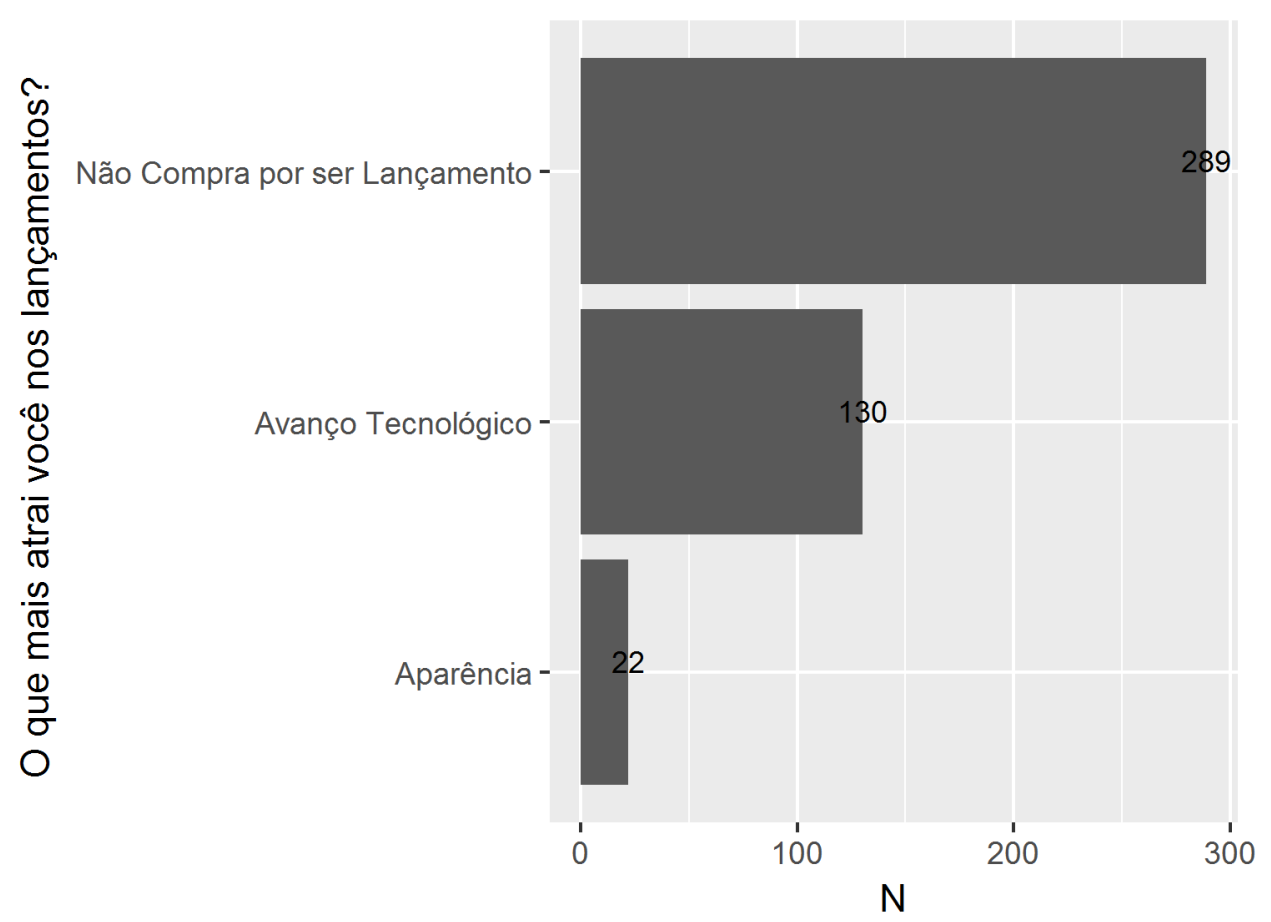

O parcelamento em poucas parcelas é a opção favorita para o pagamento de compras realizadas entre $208(46,8 \%)$ respondentes.

\section{Gráfico 17 - Opções de Pagamento}

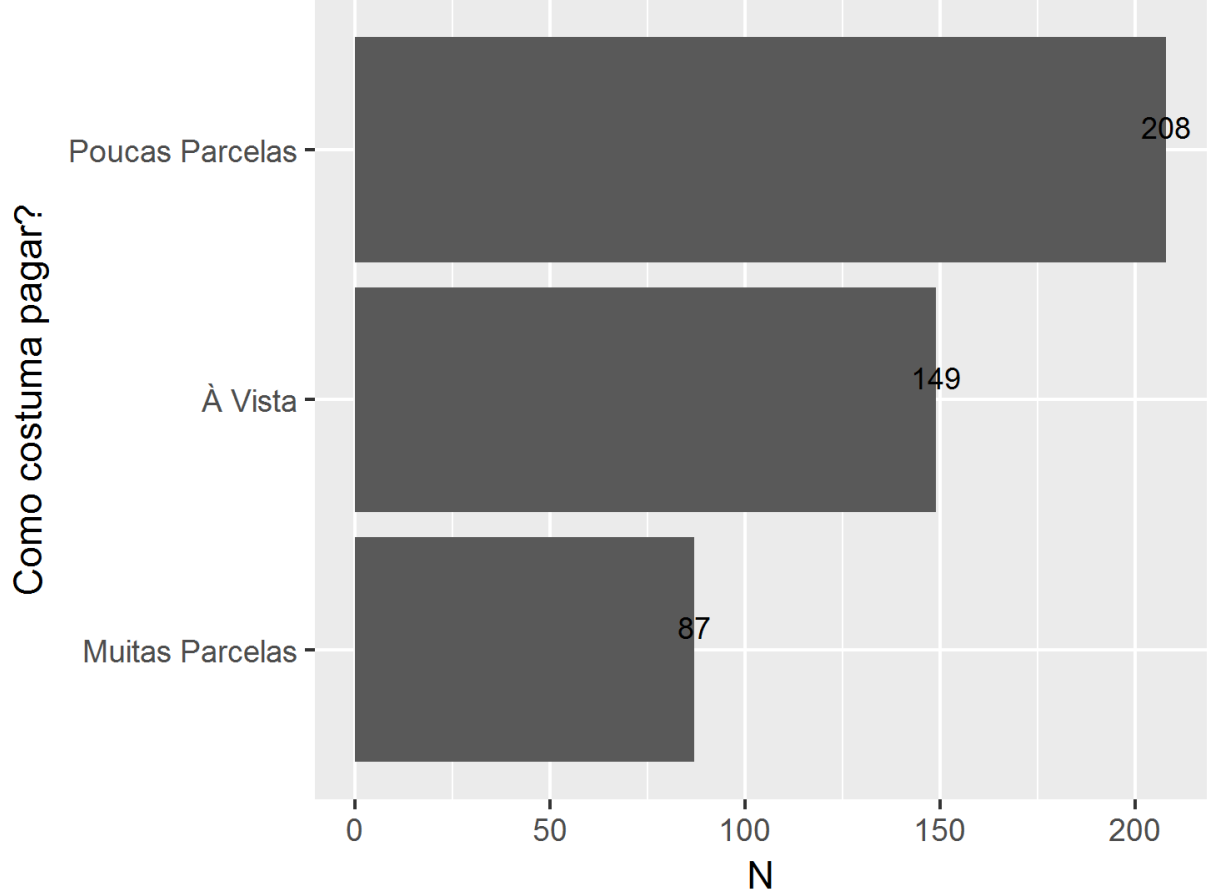

Há uma forte discordância em relação à frase "O que é novo é bom, o que é antigo é ruim", condizente com a pequena quantidade de respondentes que afirmaram adquirir produtos apenas por ser lançamento, 78,6\% daqueles que participaram da pesquisa afirmaram discordar parcial ou totalmente com a referida afirmação. 


\section{Gráfico 18 - Concordância com "O que é novo é bom"}

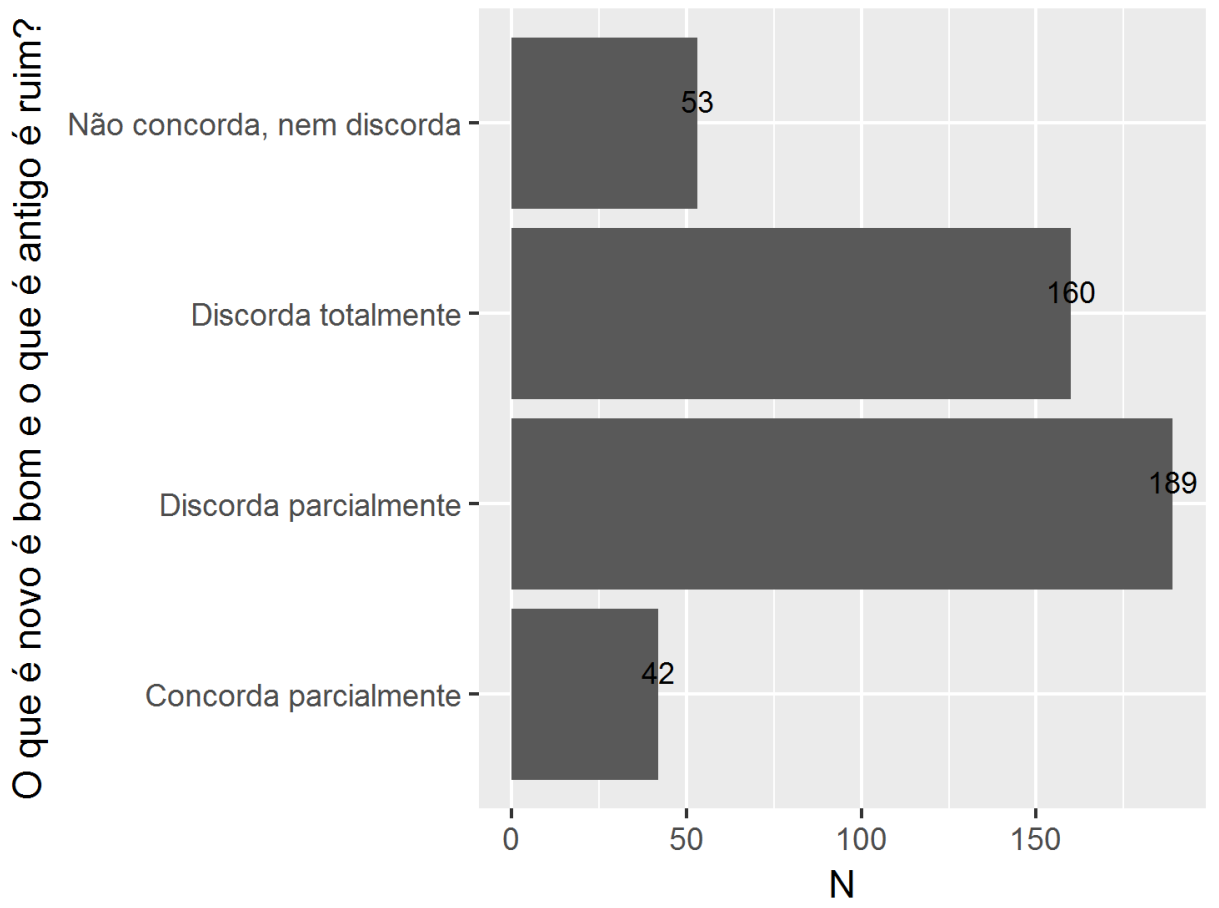

Em relação à frase "Se um produto é caro, deve durar muito" há uma clara divisão entre os respondentes.

\section{Gráfico 19 - Concordância com "Se um produto é caro, deve durar muito"}

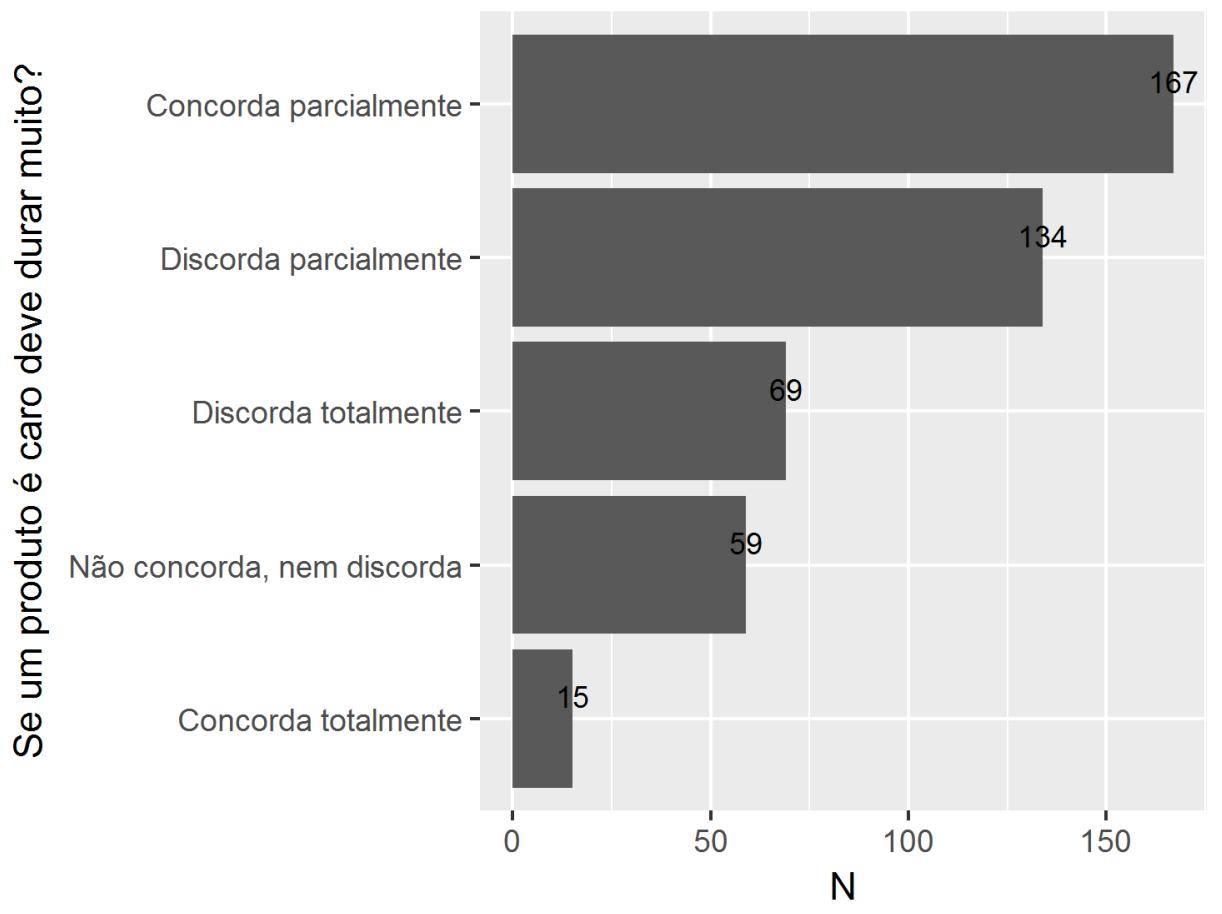

Há uma tendência a concordar tacitamente com a afirmação $(37,6 \%)$, no entanto, há ressentimento para com essa frase, já que logo em seguida emerge o respondente que discorda parcialmente dessa afirmação. De modo que essa pergunta pode se revelar de interesse como variável dependente ou independente. 
Há relativa satisfação com o valor pago pelas últimas compras do respondente $(58,5 \%)$. Contudo, há uma divisão importante na satisfação em relação ao tempo que ele durou, à luz do valor empreendido na compra. Ainda que a maioria dos respondentes afirme estar satisfeito com o tempo que o produto durou (47,5\%), ao passo que $40 \%$ afirma não estar satisfeito. É possível que esse grupo seja mais propenso a reconhecer a prática da obsolescência programa em seu dia a dia.

\section{Gráfico 20 - Satisfação com o Valor Pago}

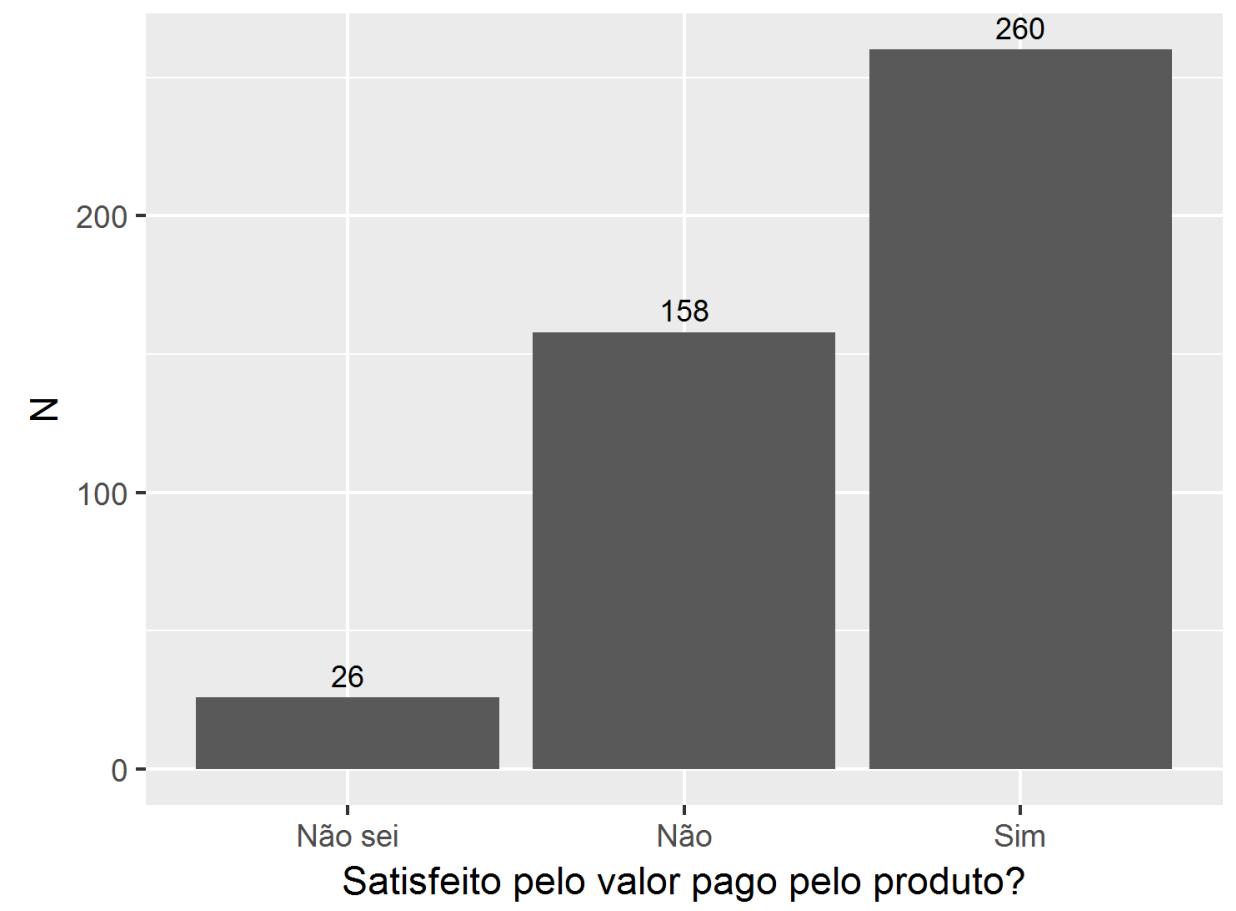

\section{Gráfico 21 - Satisfação com o Tempo que o Produto Durou}




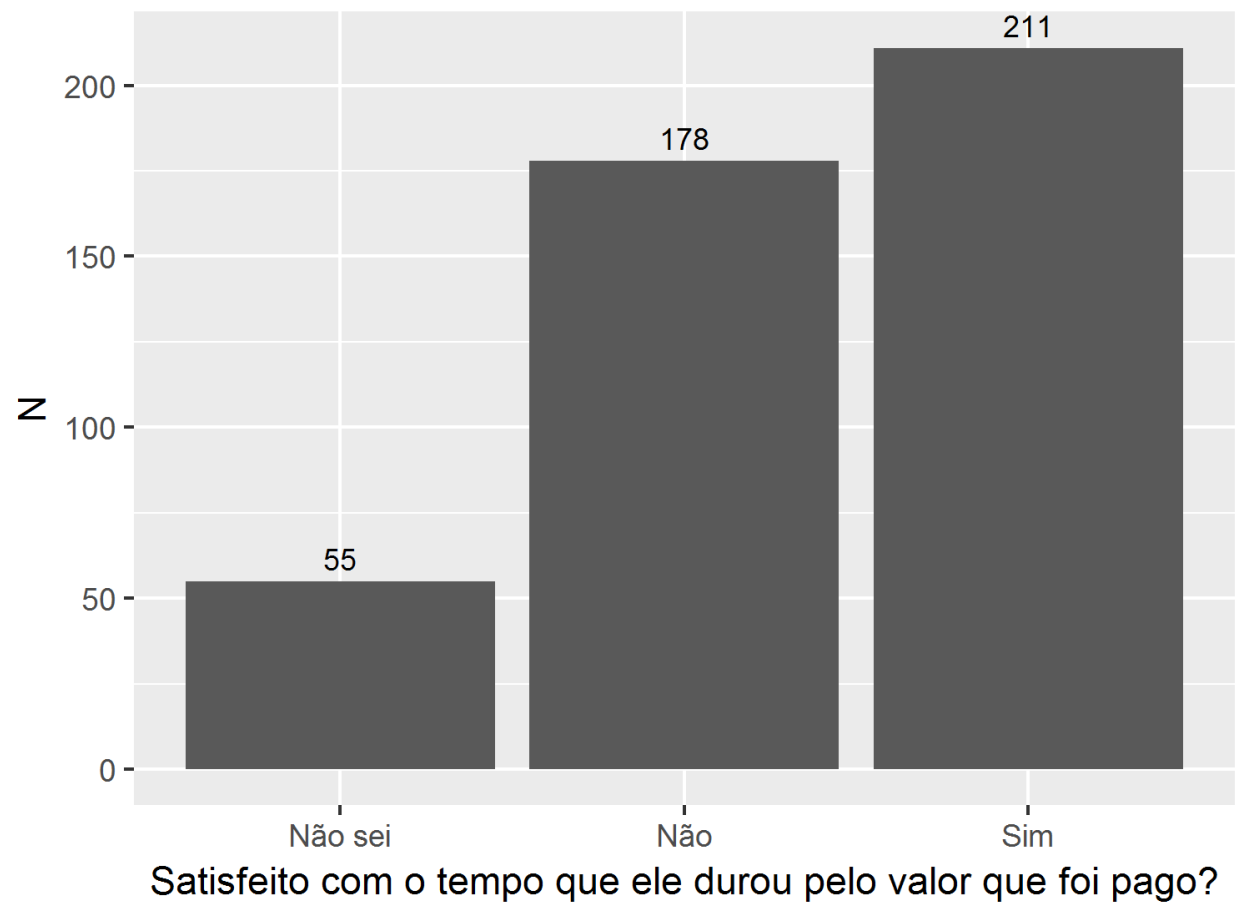

\section{Sobre Bens de Consumo}

O último bem de consumo durável comprado por 153 respondentes $(34,4 \%)$ foi um celular, seguido por eletrodomésticos grandes $(18,4 \%)$.

\section{Gráfico 22 - Último Bem de Consumo Adquirido}

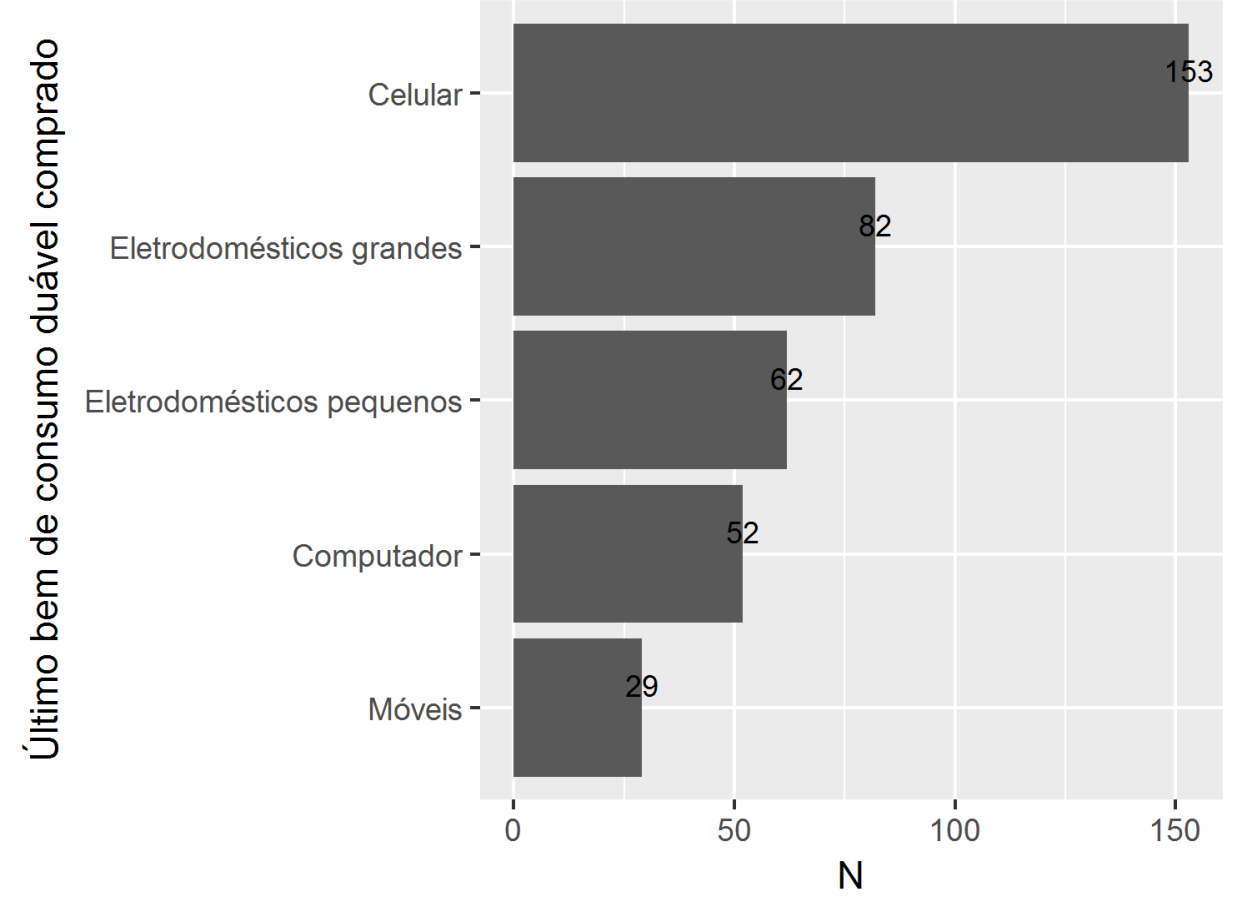

Destaque a compra de iPhones, smartphones em geral, geladeiras e notebook.

Gráfico 23 - Nuvem de Palavras Especificando o Último Produto Adquirido 


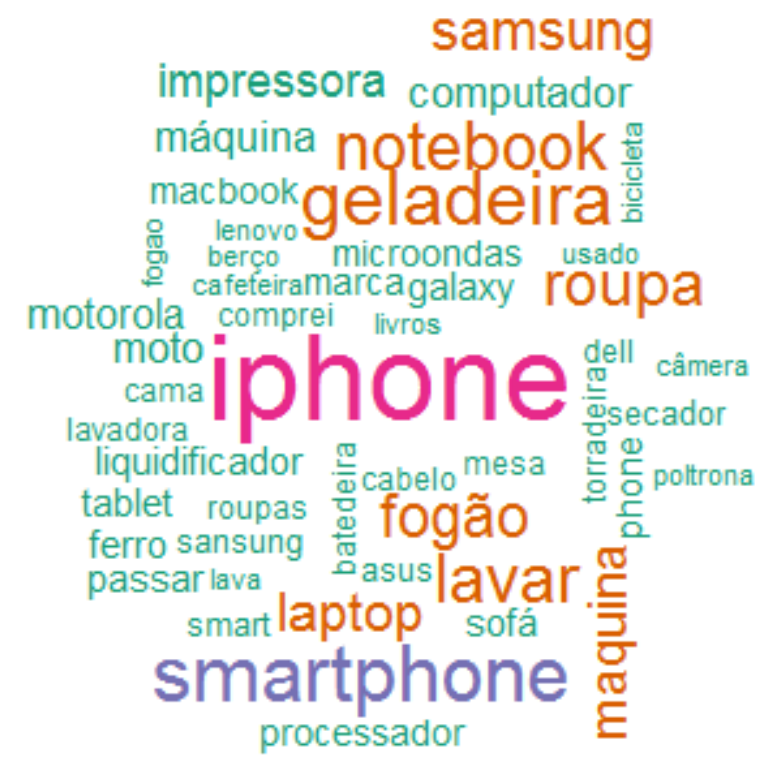

89,8\% dessas compras foi para a aquisição de produtos novos.

\section{Gráfico 24 - Que Tipo de Produto foi Adquirido}

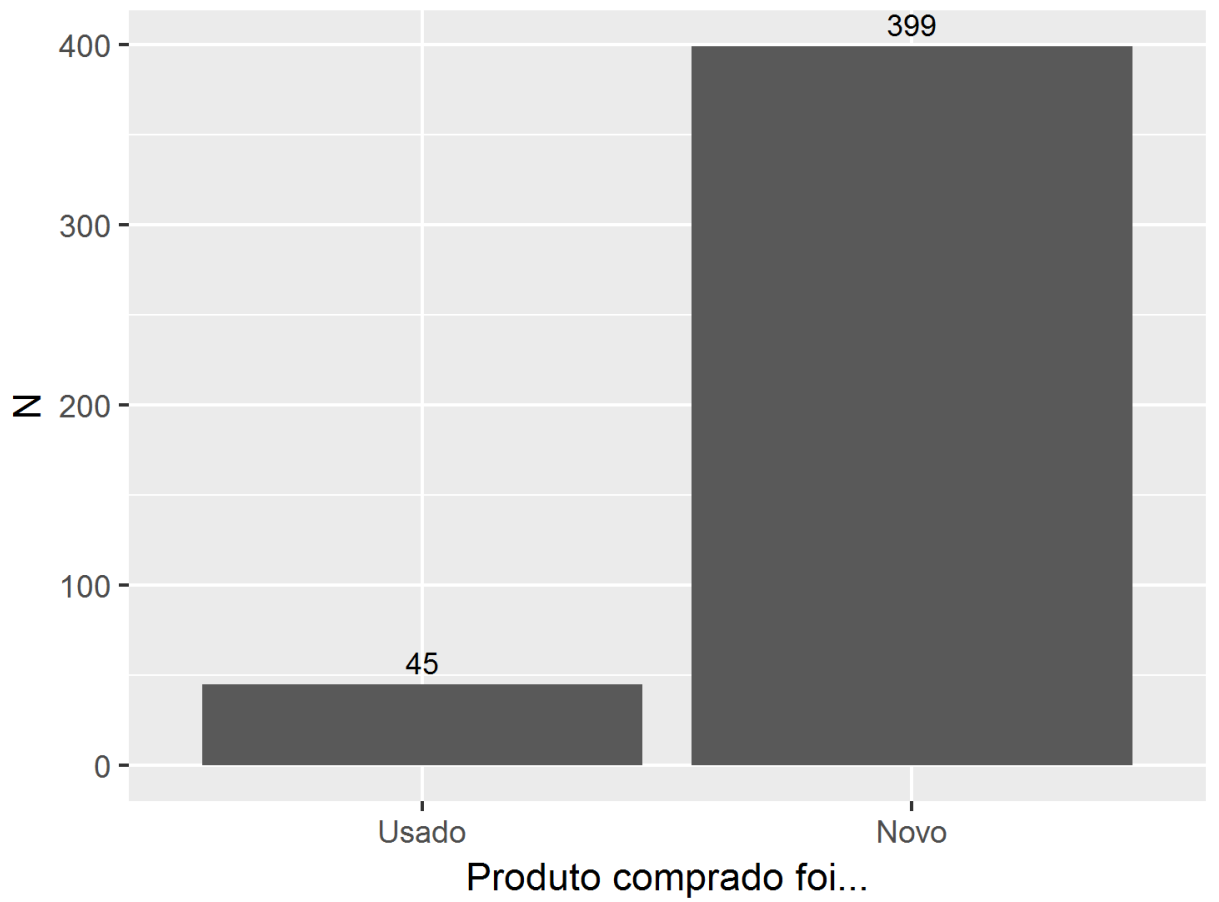

A maioria das compras $(38,5 \%)$ foi porque o produto anterior quebrou.

\section{Gráfico 25 - Motivo da Compra}




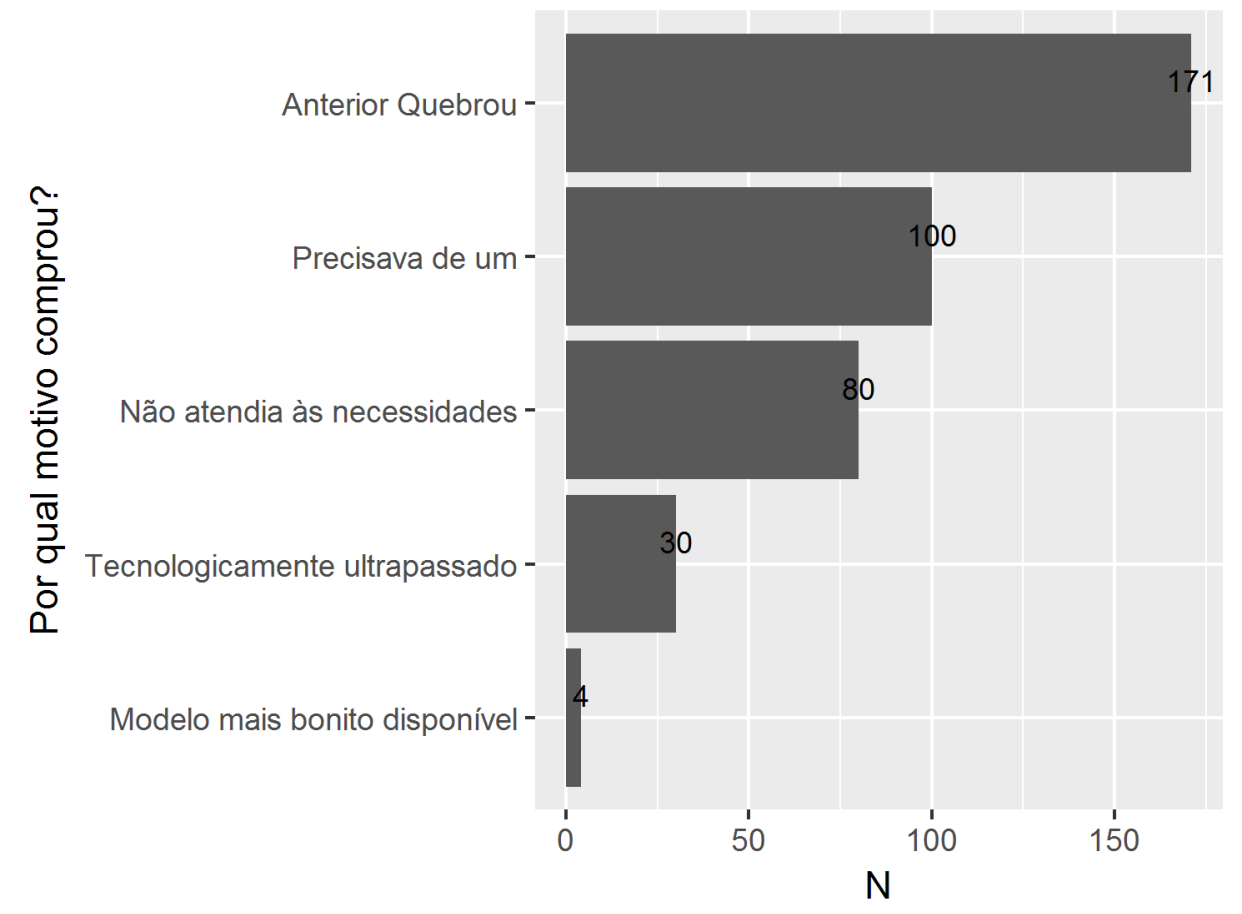

No total, 270 pessoas gostariam que o produto anterior tivesse durado mais.

\section{Gráfico 26 - Satisfação com a Durabilidade do Produto}

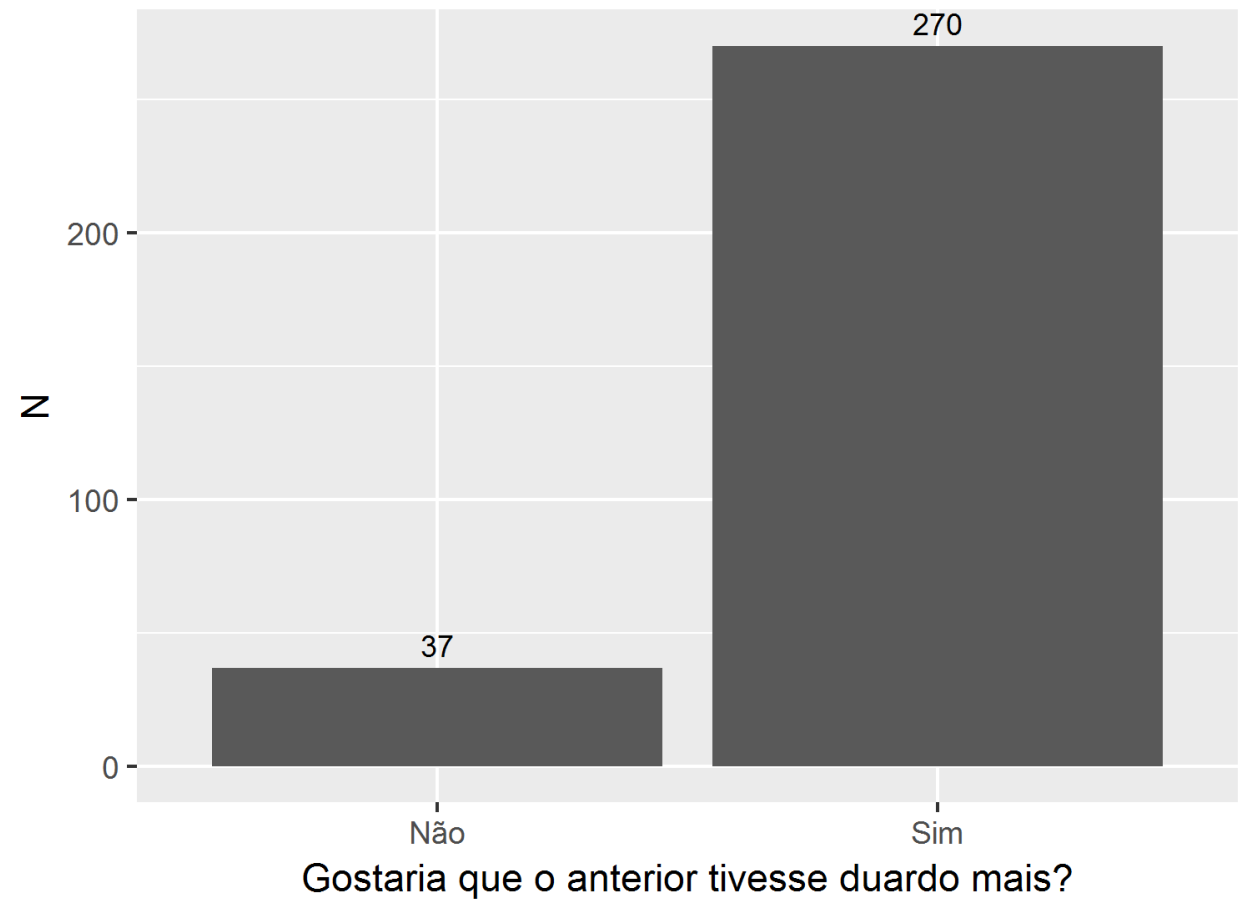

Similar ao gráfico de idade, aqui apresenta-se a distribuição da durabilidade desses produtos. A linha vermelha indica a mediana dessa distribuição, isto é, o ponto no qual a população é dividida igualmente; ordena-se a população crescentemente e aponta-se o valor que está na metade após esse ordenamento. Adota-se essa medida, já que existem valores destoantes colocados pelos respondentes, outliers, influenciando a 
média, mas não a mediana. Digressão feita, metade dos produtos anteriores durou no mínimo 31 meses (2,58 anos).

\section{Gráfico 27 - Meses de Duração do Produto}

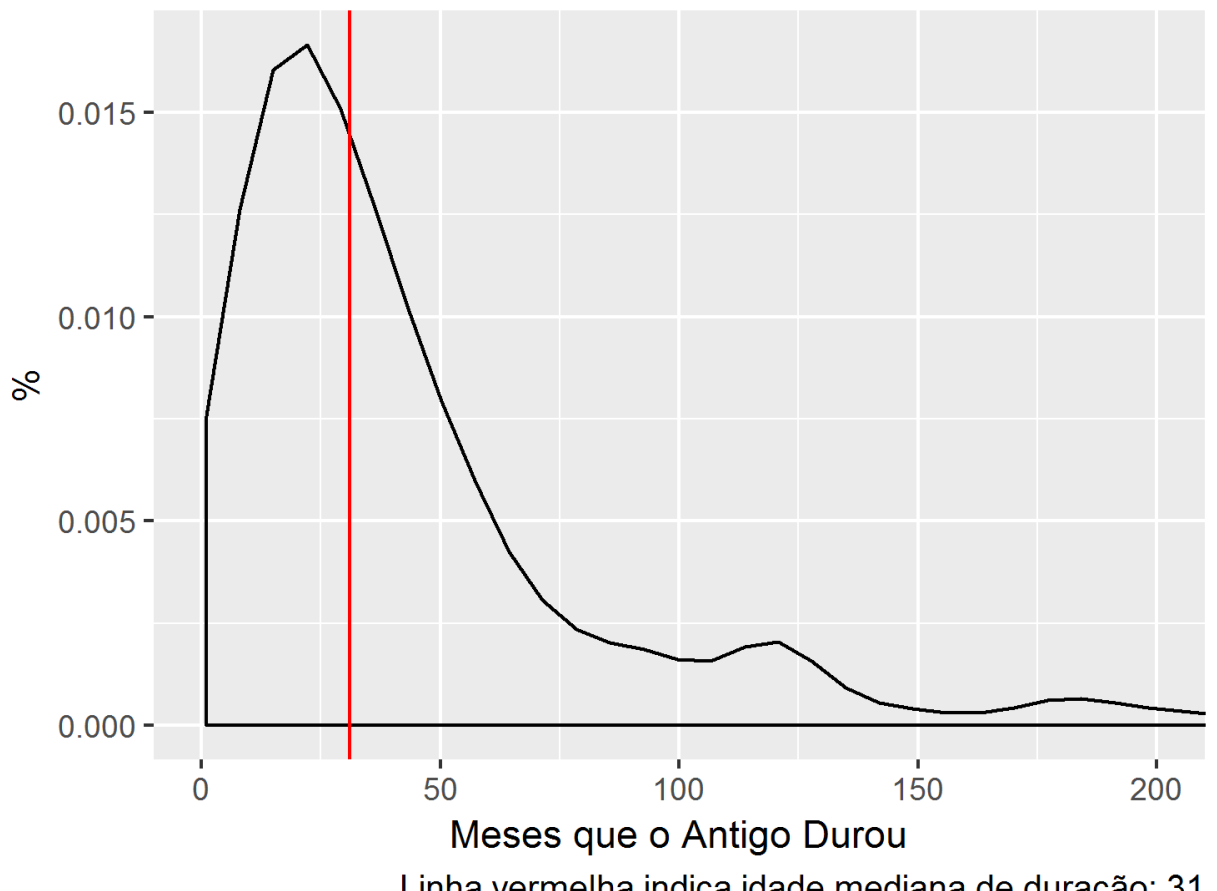

\section{Gráfico 28 - Quantos Meses o Produto Deveria Ter Durado}

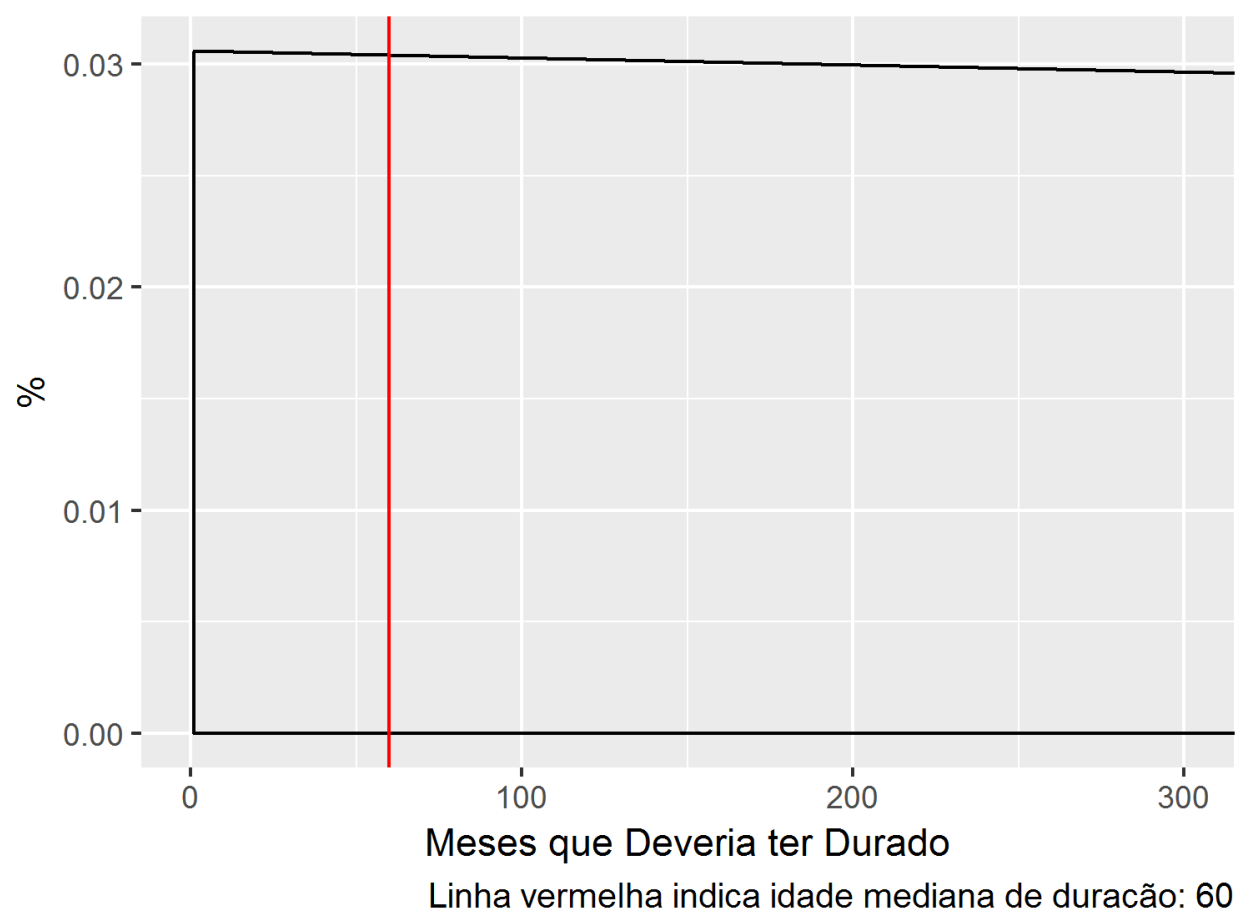

Ao mesmo tempo, metade dos respondentes afirmou que o produto deveria ter durado, no mínimo, 60 meses ( 5 anos), indicando altíssima expectativa em relação à durabilidade dos produtos adquiridos, afetando consideravelmente a distribuição da população. 
Caso o anterior ainda funcionasse, $68,2 \%$ afirmaram que não comprariam outro.

\section{Gráfico 29 - O que teriam feito se o produto não tivesse quebrado}

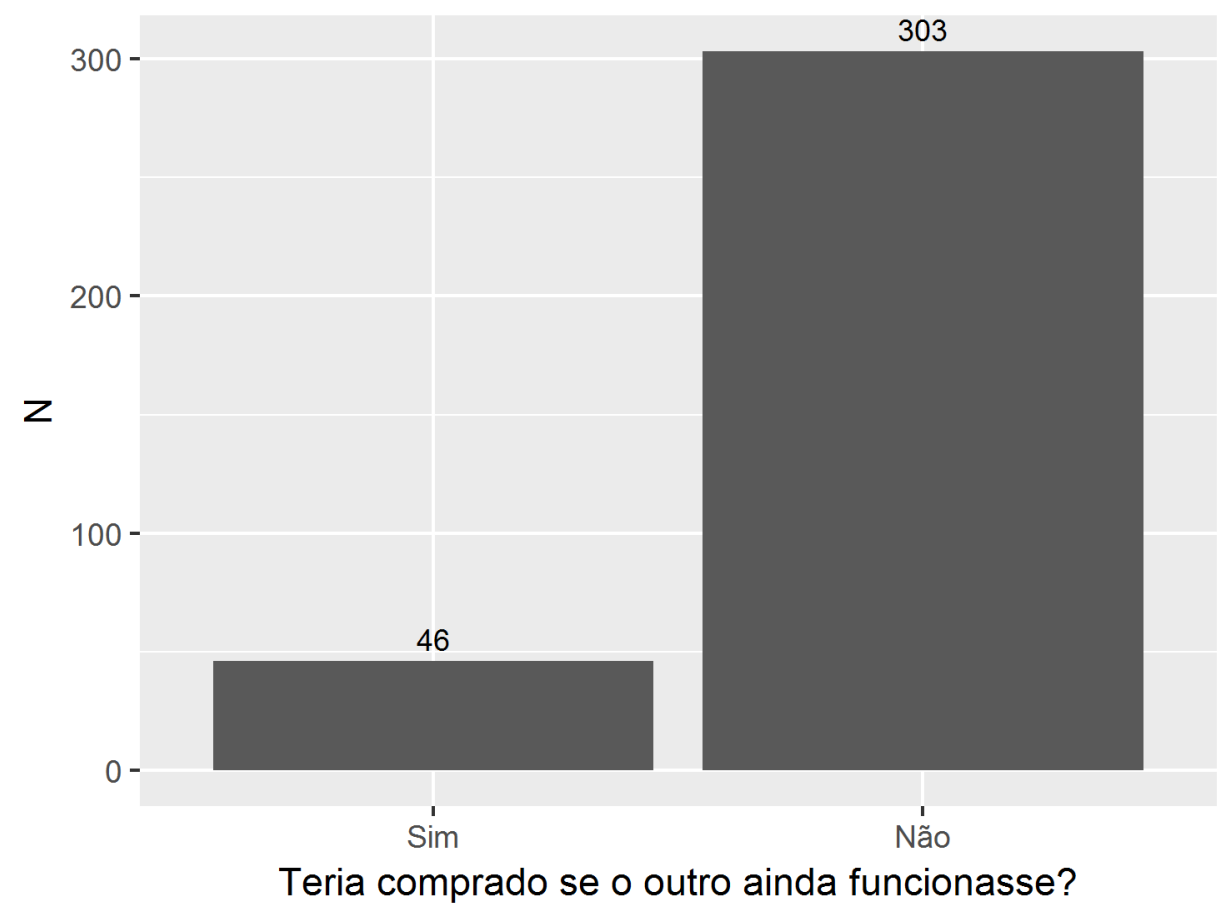

Ao todo, 226 pessoas afirmaram que procuraram a assistência técnica.

\section{Gráfico 30 - Tentativas de Conserto}

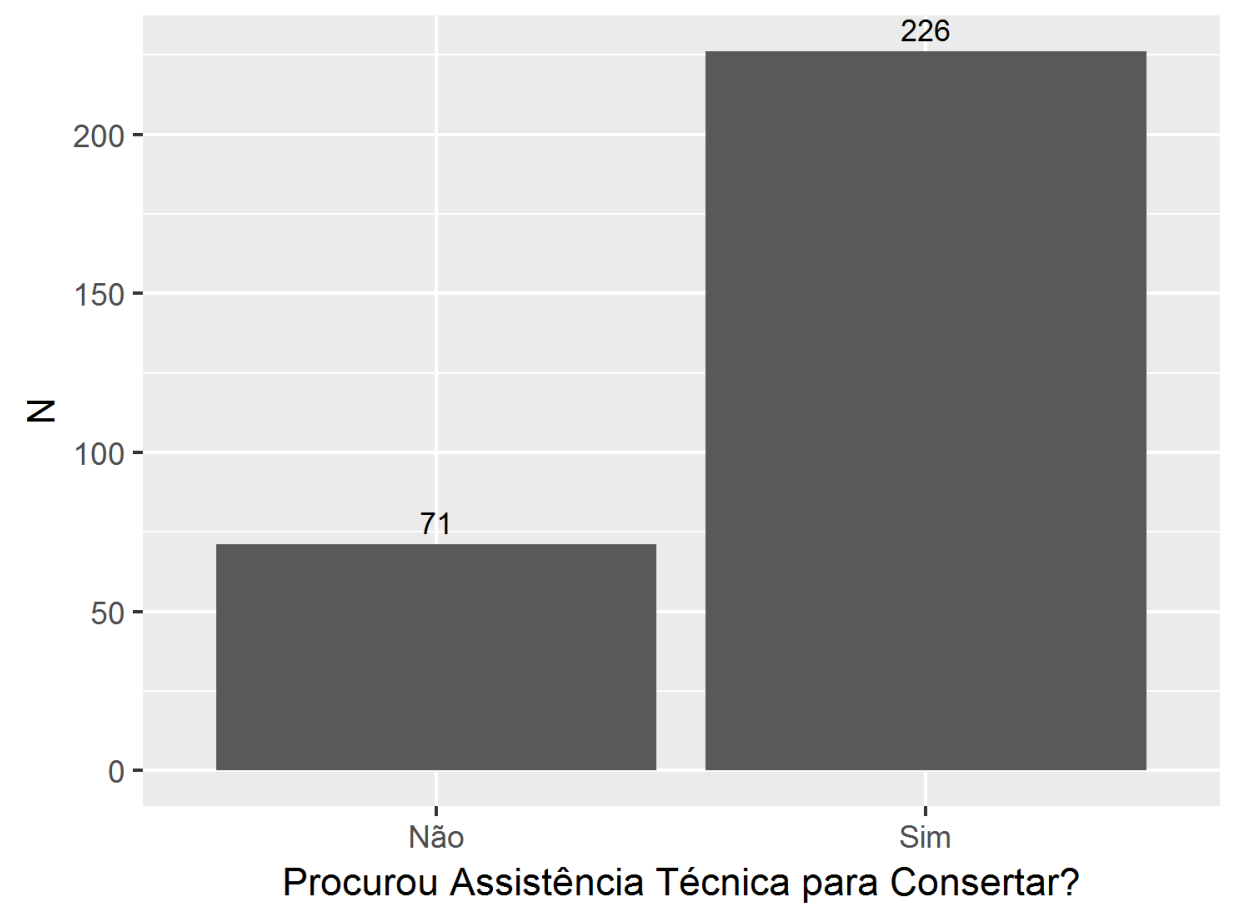

Ainda que o conserto não tenha dado certo para 210 respondentes $(47,2 \%)$, sobretudo porque não compensava ou o preço do conserto era muito alto.

\section{Gráfico 31 - Motivos pelo Fracasso no Conserto}




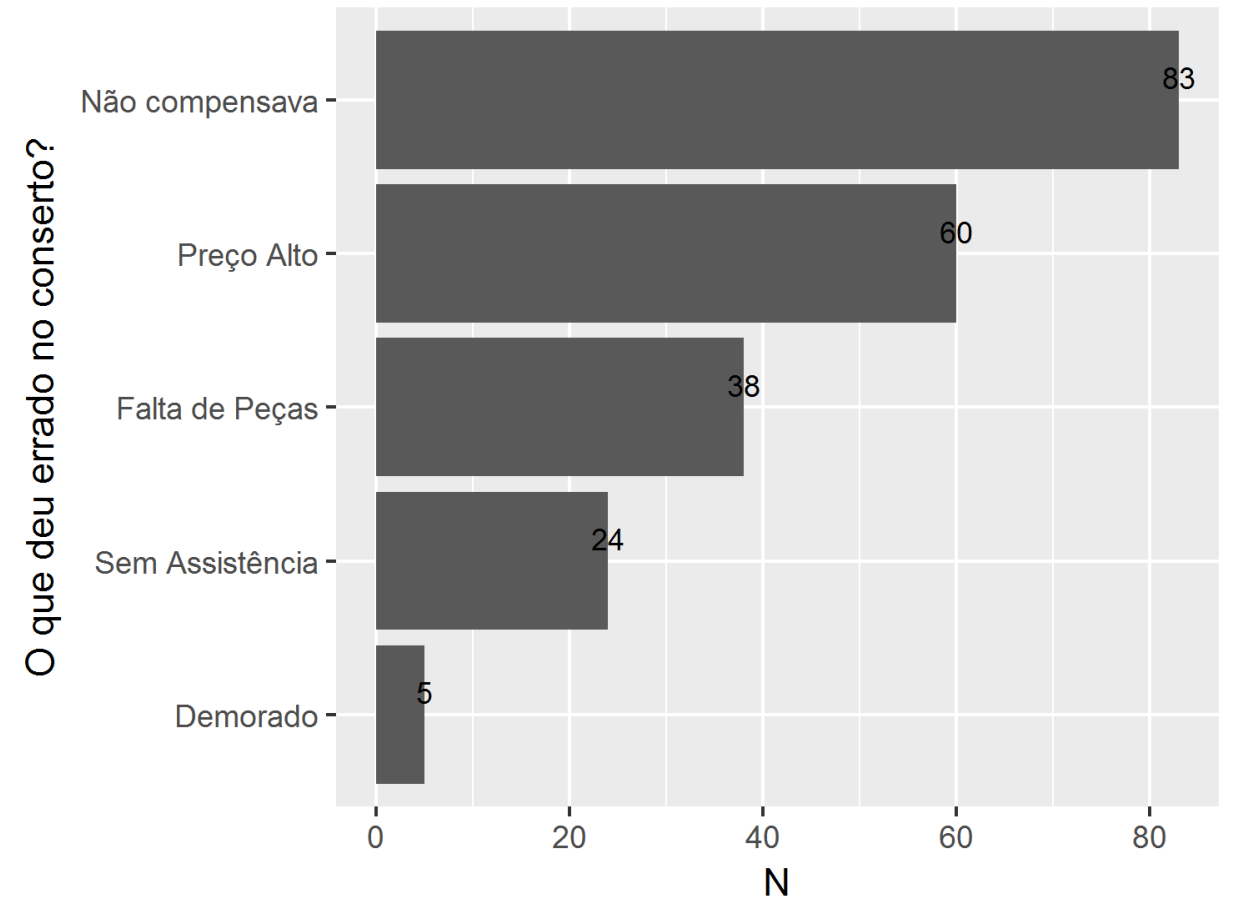

Assim, a maior parte dos respondentes afirmou que atualmente o produto anterior se encontra jogado, encostado num canto $(25,6 \%)$.

\section{Gráfico 32 - Destino do Produto Quebrado}

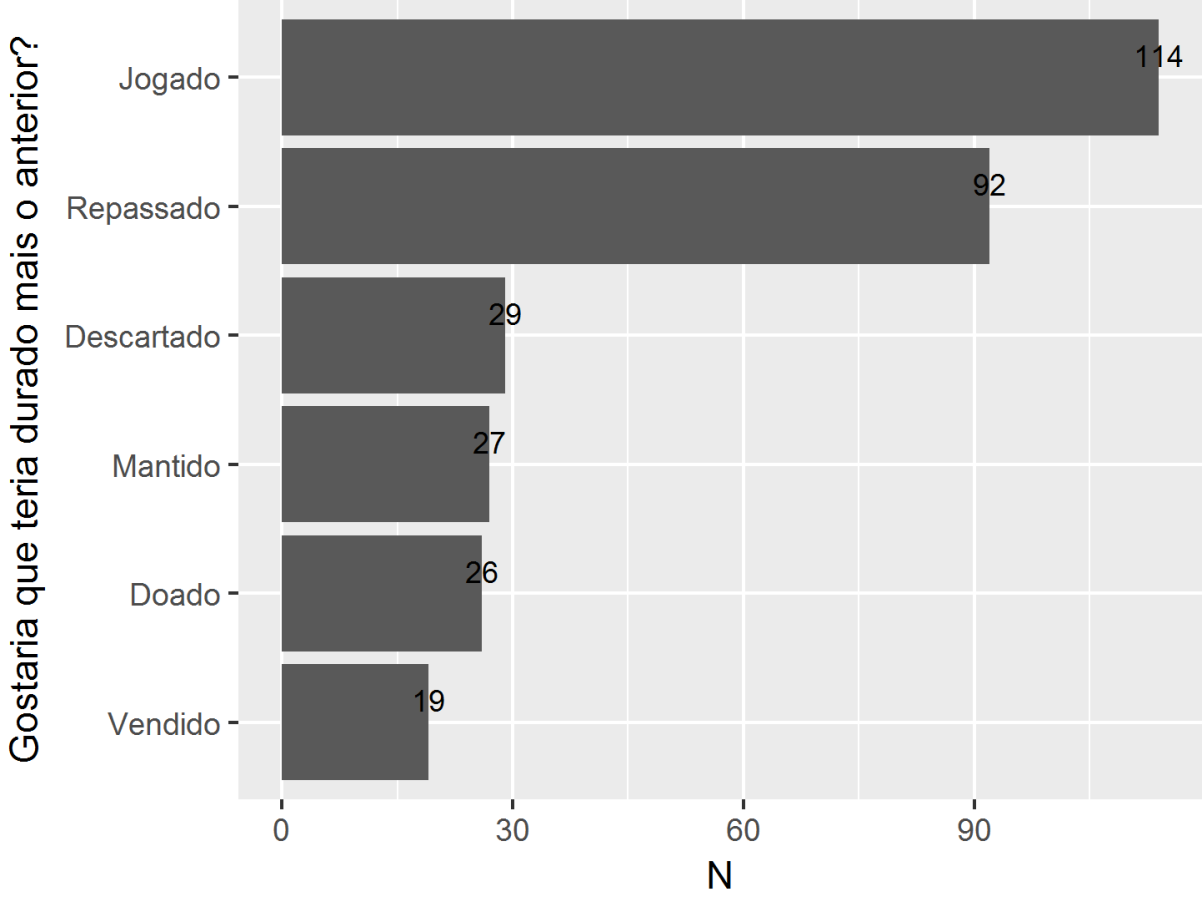

O produto que é trocado com maior frequência é o celular, sobretudo por motivos de quebra, conforme aduz a nuvem de palavras indicada na sequência.

\section{Gráfico 33 - Nuvem de Palavras do Produto Trocado com Maior Frequência}




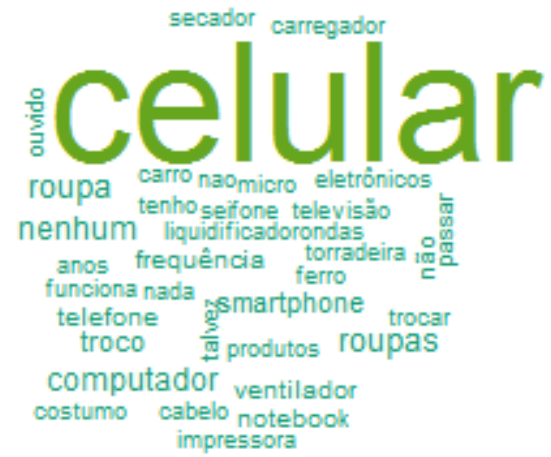

Gráfico 34 - Nuvem de Palavras com o Motivo de Troca do Produto

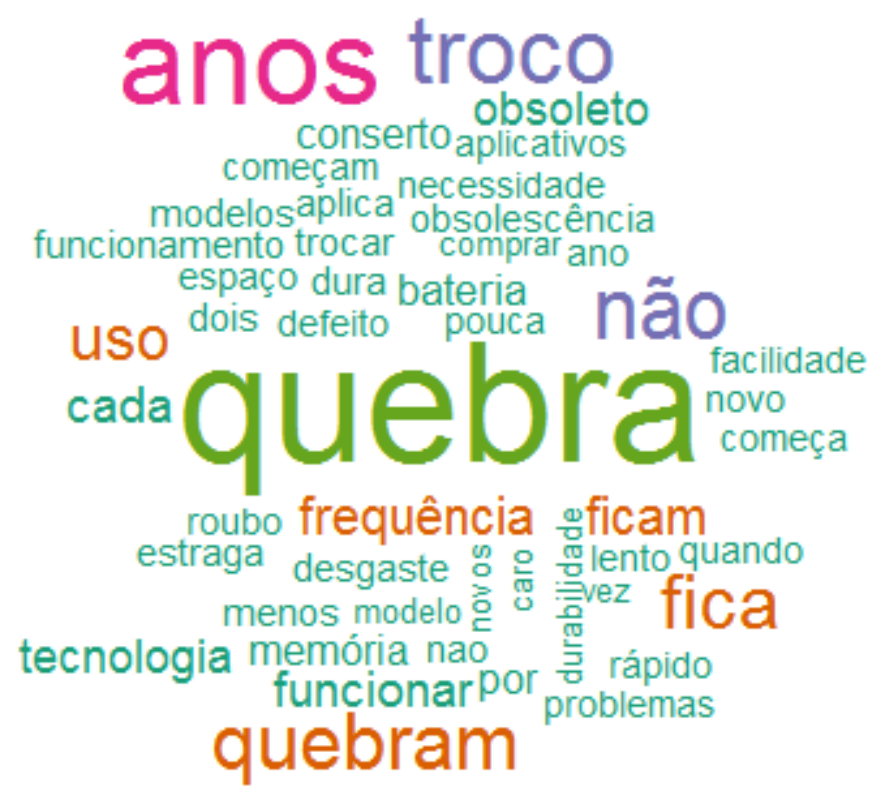

Os produtos mais antigos dos respondentes são, em geral, micro-ondas, carros, fogões, computadores e máquinas de lavar.

Gráfico 35 - Nuvem de Palavras dos Produtos Mais Antigos em Uso 


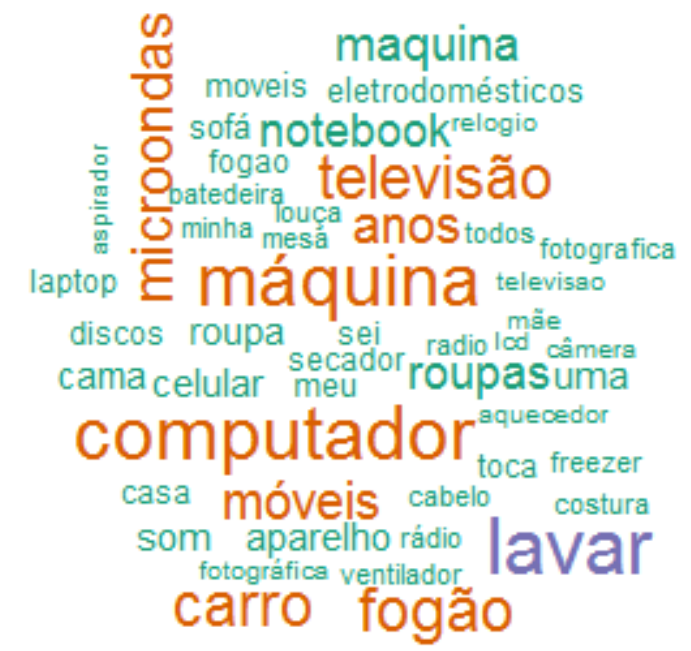

Até metade desses produtos está em uso há até 12 anos, isto é, a mediana de há quanto tempo esses produtos está em uso é de 12 anos.

\section{Gráfico 36 - Distribuição do Tempo de Uso dos Produtos Mais Antigos}

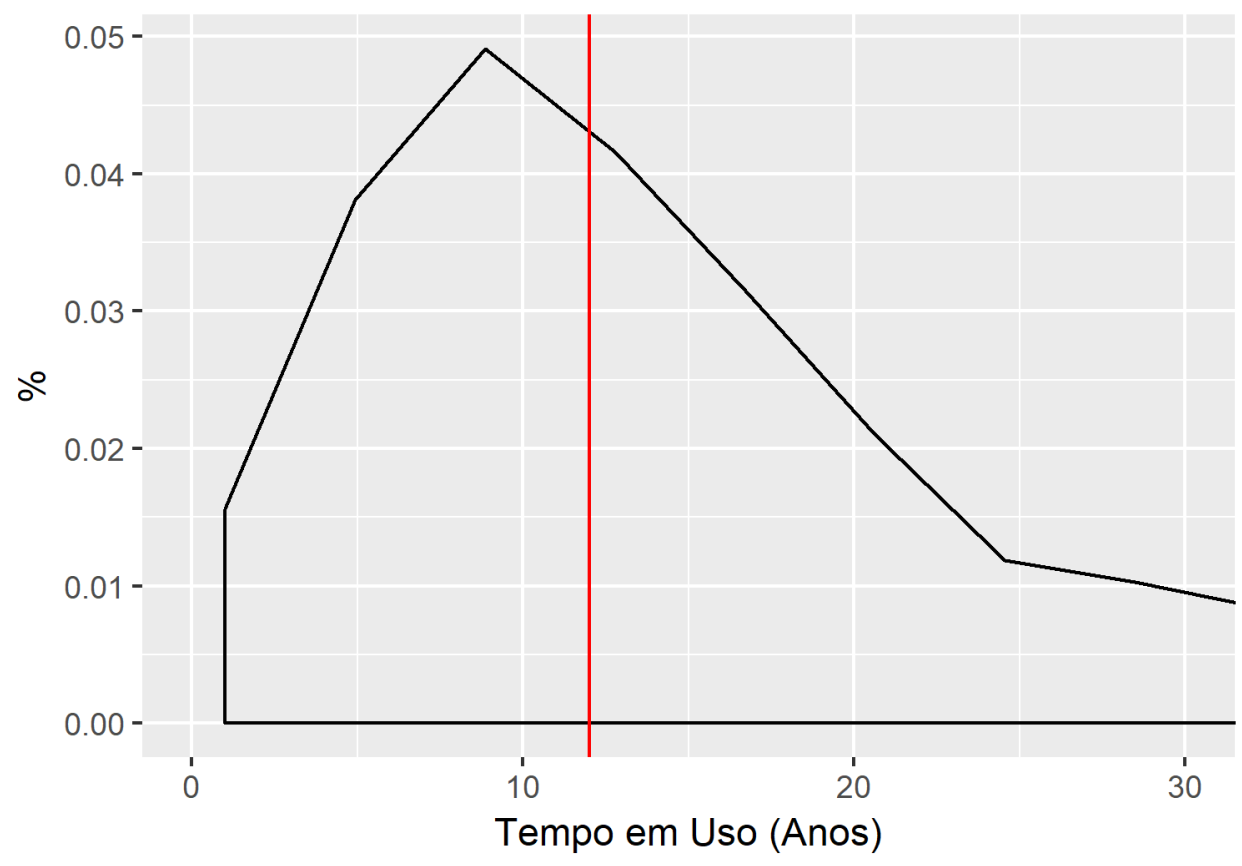

Linha vermelha indica idade mediana de produto mais antigo: 12

\section{Sobre o Tema de Obsolescência Programada}

Finalmente, sobre o tema central desse trabalho, 324 (72,9\%) dos respondentes diz que conhece o termo obsolescência programada antes de serem apresentados à definição do tema, possivelmente esse índice é afetado pelo alto poder aquisitivo da 
população, bem como sua área de atuação, já que boa parte dos respondentes é designer, lembrando que essa pergunta foi feita antes da pesquisa apresentar a definição do termo ao participante.

\section{Gráfico 37 - Conhecimento sobre o tema Obsolescência Programada}

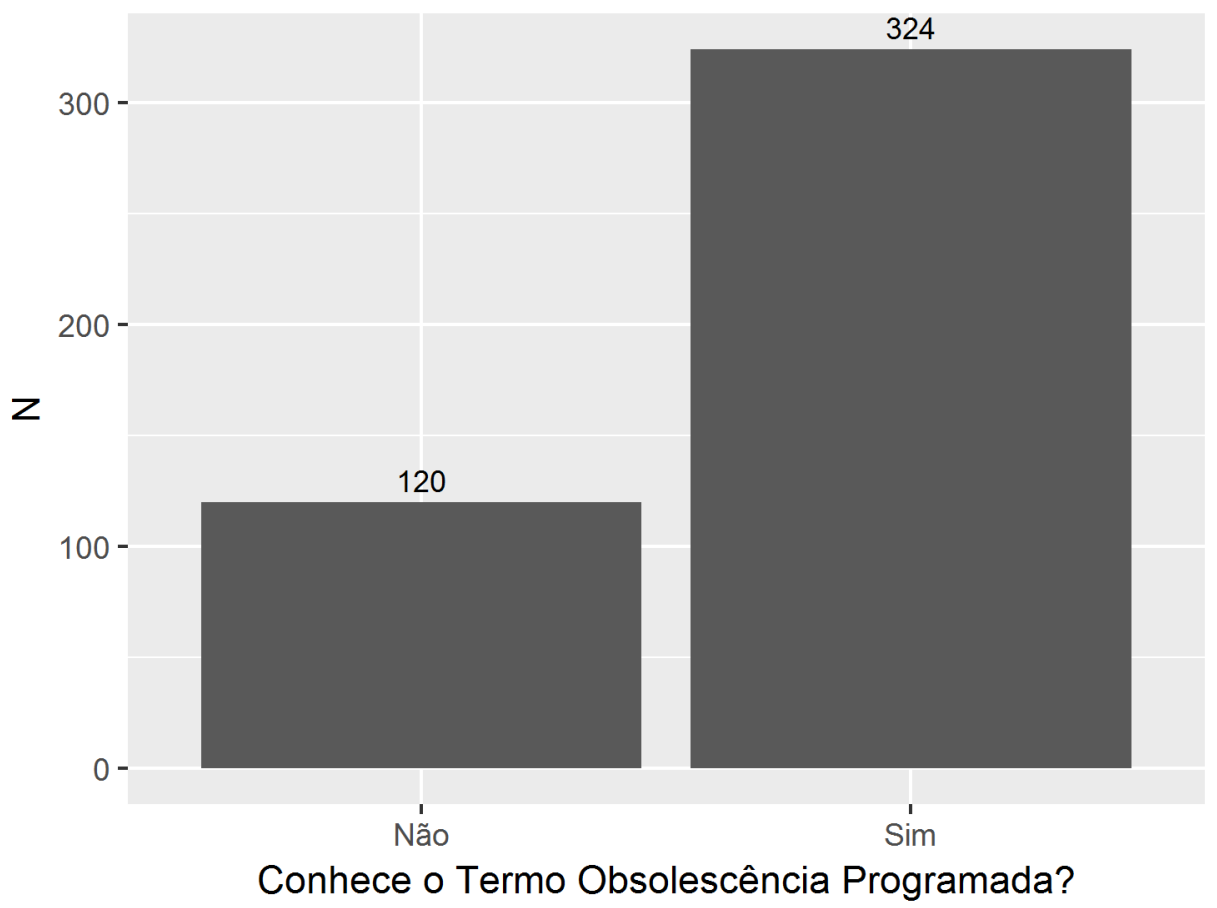

\section{Gráfico 38 - Reconhecimento de Obsolescência Programada}

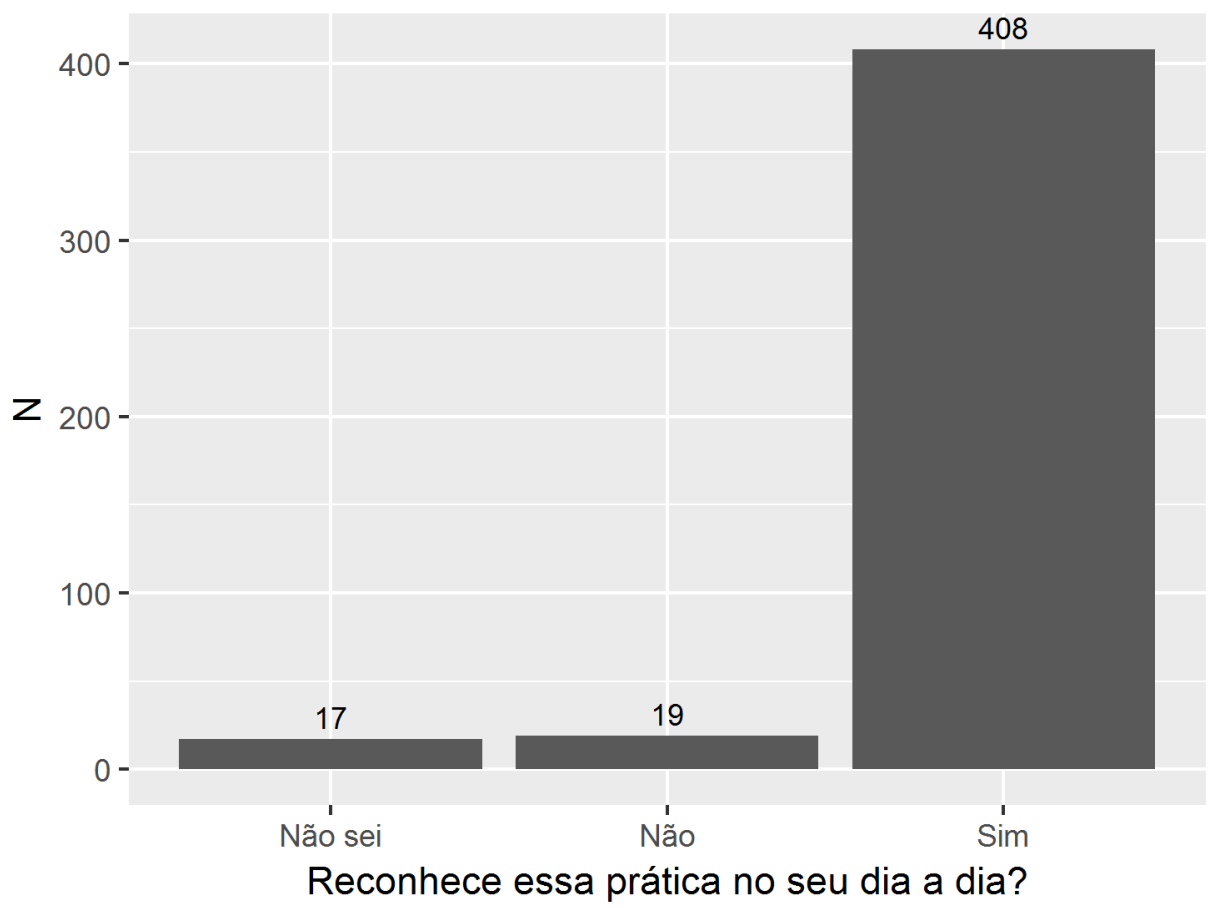

Após a apresentação do termo, 91,8\% dos respondentes disseram reconhecer a prática. Além disso, há uma ligeira associação da prática a aparelhos eletrônicos em geral, computadores, peças e celulares, sobretudo. 

Percebida

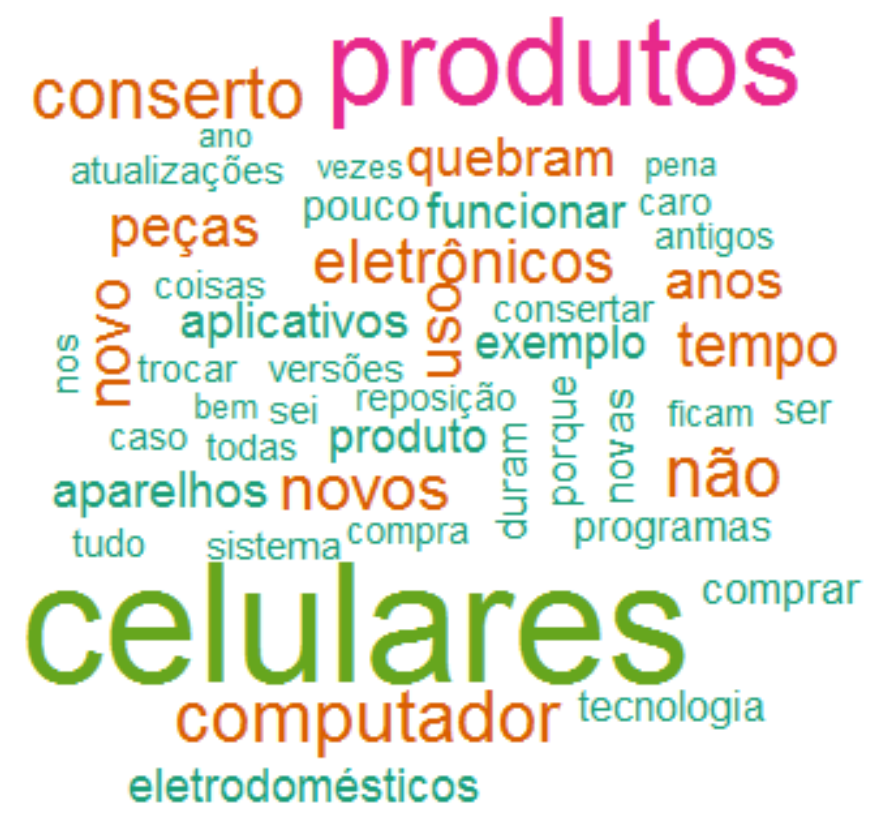

\section{Gráfico 40 - Setores Empresariais Associados à Prática}

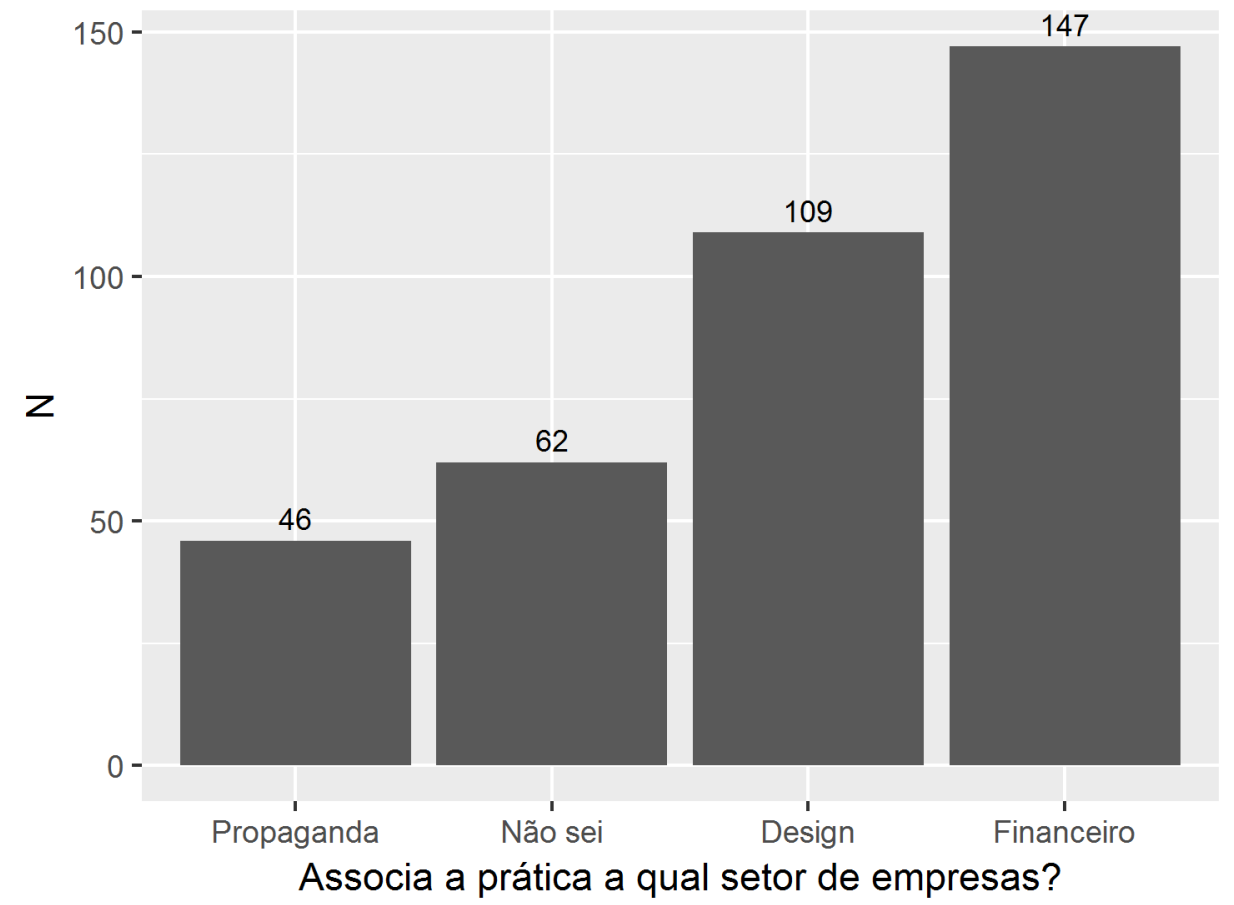

De modo que o principal setor de empresas associado à prática foi o financeiro para $33,1 \%$ dos respondentes, possivelmente por querer lucrar sobre a quebra dos produtos, conforme ilustra a nuvem de palavras em seguida. Por fim, como poderia se esperar, a prática incomoda quase a totalidade dos respondentes, 414 dos 444 participantes do estudo. 


\section{Gráfico 41 - Incômodo com a Prática}

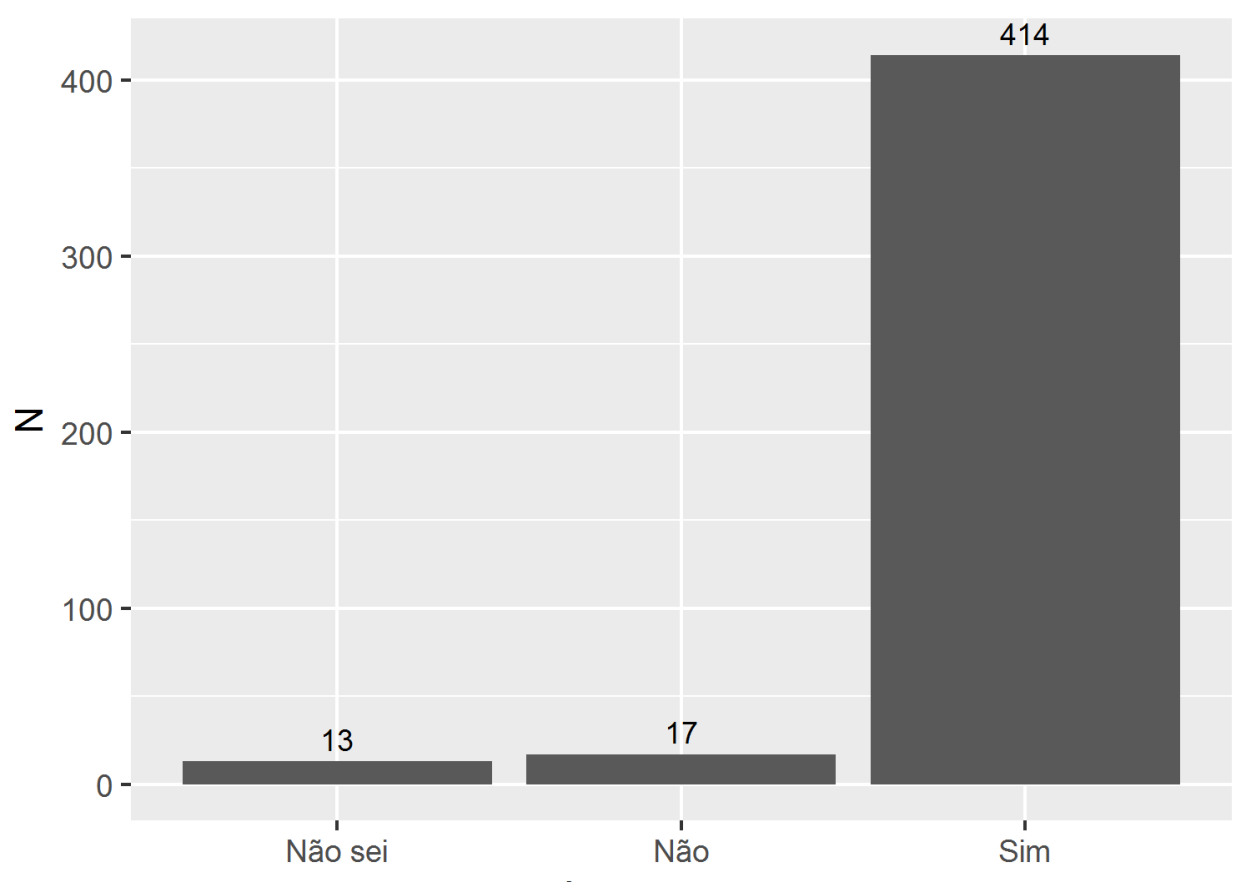

A Prática te Incomoda?

\section{Testes de Associação}

Para investigar a associação entre variáveis de interesse nessa pesquisa recorremos ao teste de qui-quadrado. Em resumo, este teste investiga se a frequência observada de mulheres e homens que conhecem o termo obsolescência programa, por exemplo, é estatisticamente diferente da frequência matematicamente esperada, ou seja, nesse caso hipotético, o teste de qui-quadrado analisa tão-somente se o conhecimento do termo obsolescência programada é independente ou não do gênero do respondente.

Resumidamente, testa-se se duas variáveis nominais são independentes ou não entre si. De forma que a hipótese nula deste teste é de que as variáveis dependente e independente não estão associadas. A estatística é auferida a partir da somatória da diferença entre a frequência observada $(\mathrm{O})$ e esperada $(\mathrm{E})$ em cada célula $(j)$ da tabela

- 2 . De modo que os graus de liberdade, necessários para o teste da hipótese nula são obtidos por meio da multiplicação do número de linhas menos um e o número de colunas menos um. Ver mais em Agresti e Finlay (2012, capítulo 8)².

Optamos por apresentar esses resultados por meio de ilustrações gráficas, na maioria dos cruzamentos realizados. Busca-se com essa estratégia facilitar eventuais associações entre as variáveis visualmente. É importante ressaltar que nesse teste, no caso de gênero e conhecimento do termo obsolescência programada não serem independentes, a proporção de conhecimento do termo entre homens é muito diferente

${ }^{2}$ AGRESTI, A.; FINLAY, Barbara. Métodos Estatísticos para as Ciências Sociais. São Paulo: Penso Artmed, 2012. 
da mesma proporção entre mulheres. Além disso, no rodapé de cada gráfico incluímos a estatística qui-quadrado auferida em cada associação, junto com o p-valor estimado. Aqui, quanto mais próximo de 0 o p-value - que varia entre 1 e 0 , grosso modo - maior a significância estatística e, portanto, mais evidente a associação entre as variáveis, indicando que a variável independente afeta a variável dependente em questão. Estabelecemos arbitrariamente como valor de rejeição à hipótese nula um p-value inferior a 0,05 .

\section{Impacto do Gênero}

Iniciamos os testes acessando o impacto do gênero sobre a importância que a assistência técnica tem no momento da compra. Como se pode ver, o gênero do respondente não afeta essa avaliação. Visualmente isso é observado pelo tamanho semelhante das cores referentes a indivíduos do sexo masculino e feminino em cada uma das respostas possíveis nessa questão. Estatisticamente, isso é observado por meio de um elevado p-value, 0,6418. Caso houvesse algum tipo de associação entre as variáveis, o p-value seria, hipoteticamente, de 0,002, levando a um considerável contraste entre a importância de cada gênero em cada resposta possível, quando da avaliação da relevância da assistência técnica no momento de aquisição do produto.

\section{Gráfico 42 - Associação Gênero e Relevância Assistência Técnica}




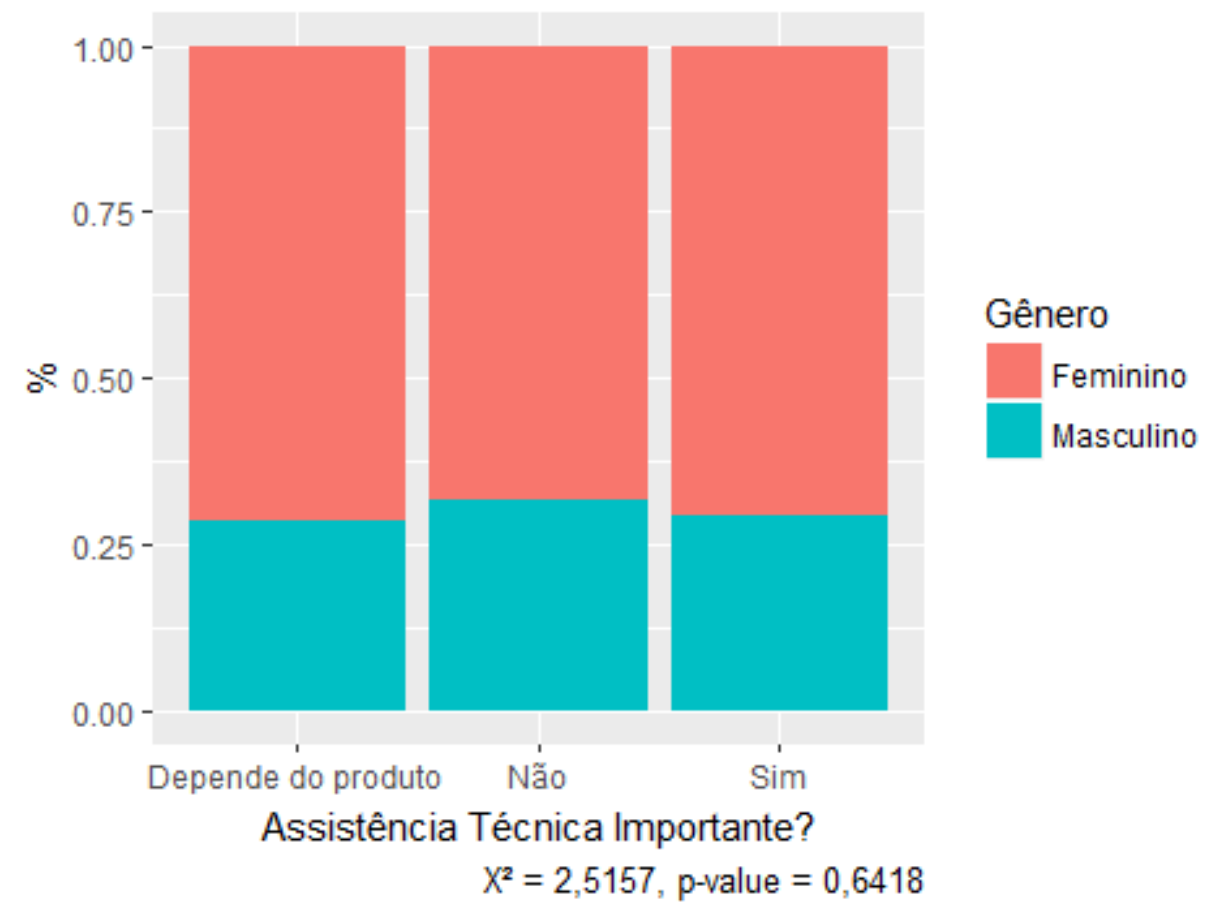

O mesmo ocorre na compra de produtos usados, o gênero do respondente é independente da possibilidade de aquisição de produtos usados.

\section{Gráfico 43 - Associação Gênero e Aquisição de Produtos Usados}

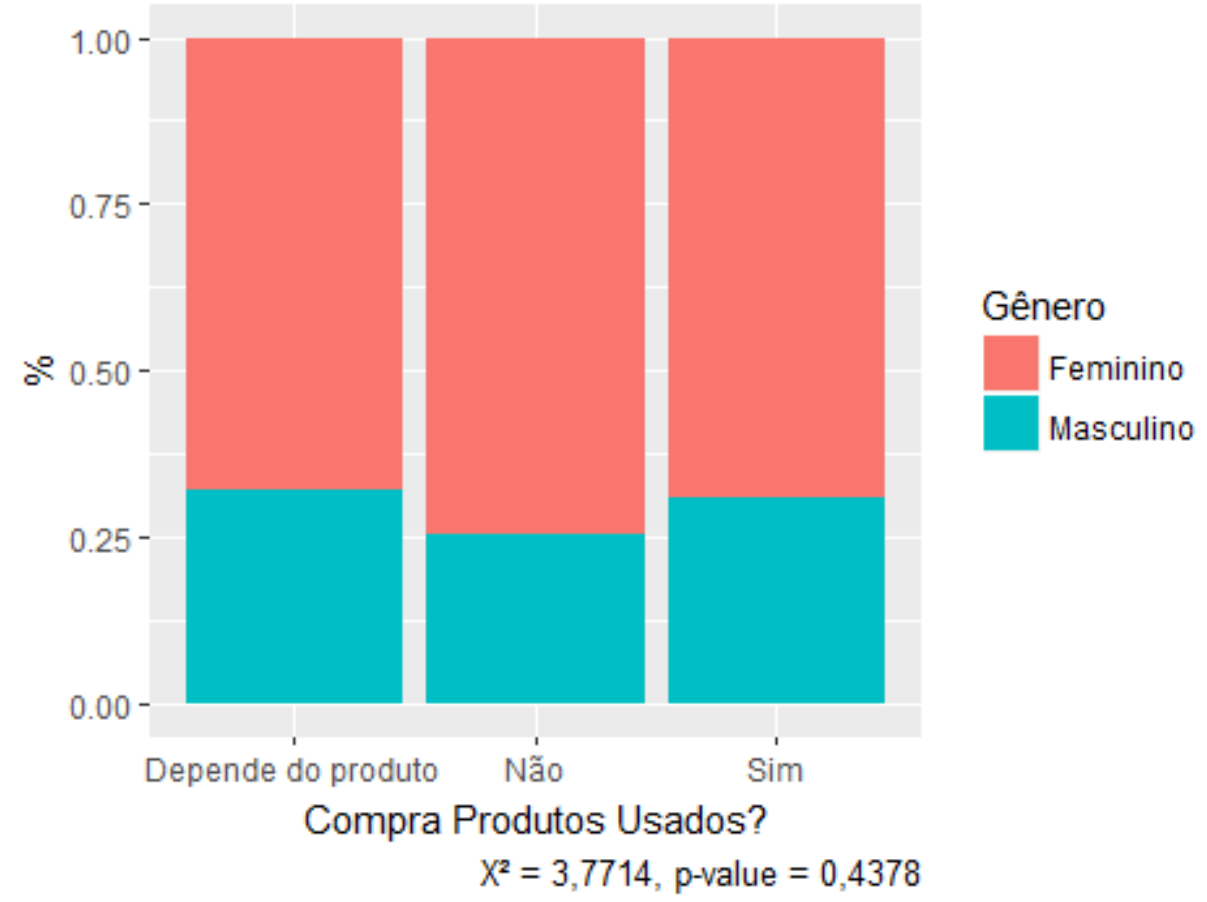

Por outro lado, como se vê abaixo, há uma associação entre a forma de pagamento e gênero. Homens tendem a pagar seus produtos à vista proporcionalmente mais do que mulheres, lembrando que mesclamos os respondentes que afirmaram pagar seus produtos por meio de muitas ou poucas parcelas. 


\section{Gráfico 44 - Associação Gênero e Forma de Pagamento}

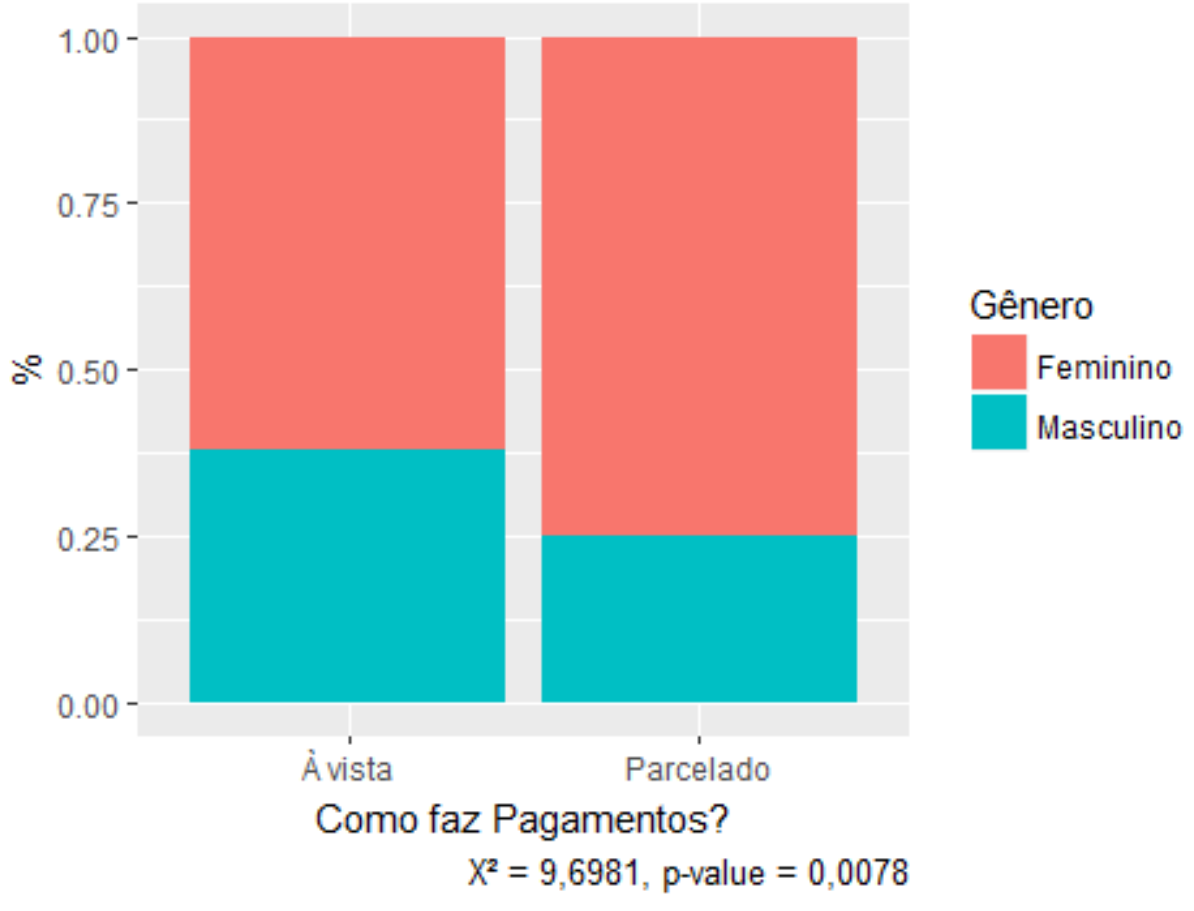

Não há associação entre gênero e a concordância com a frase "Se é caro, deve durar muito".

\section{Gráfico 45 - Associação Gênero e Concordância com "Se é caro, deve durar muito"}

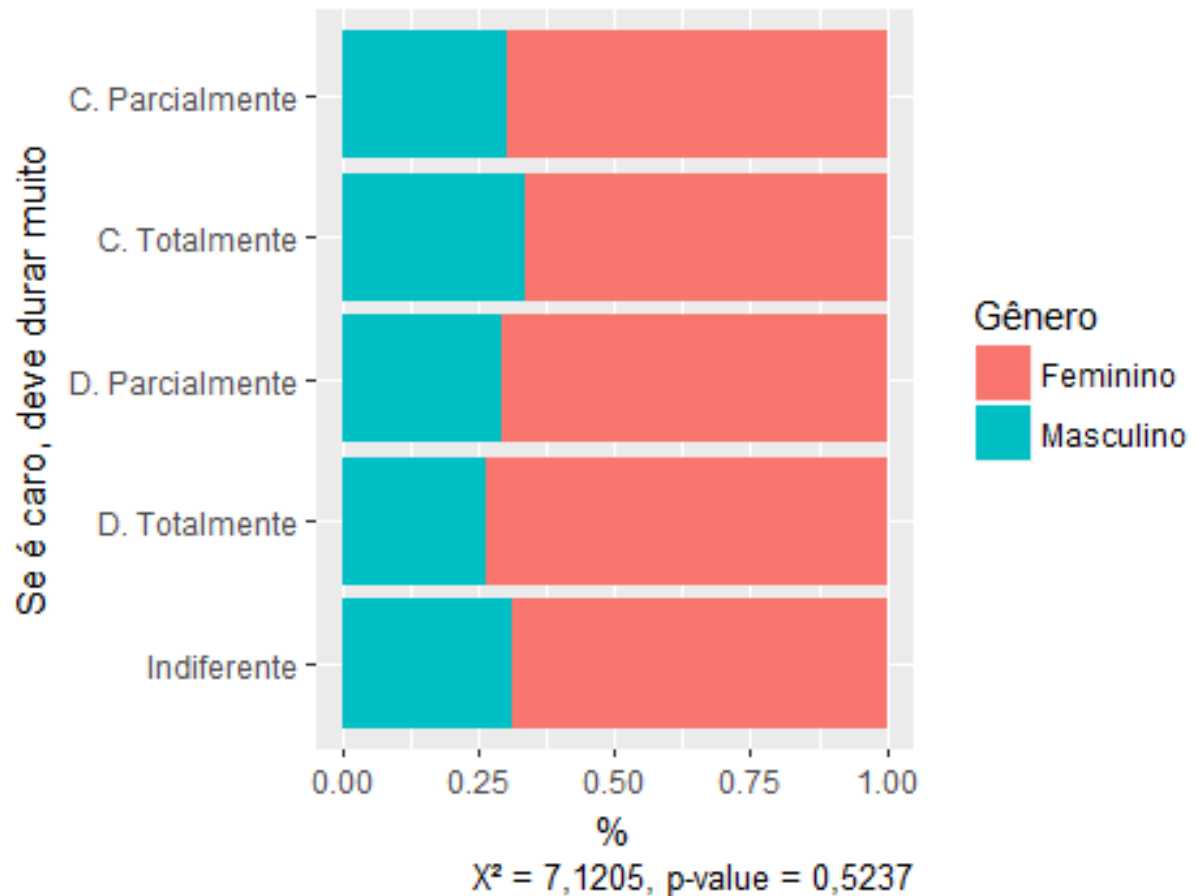

O mesmo ocorre na relação entre gênero e satisfação com a durabilidade do produto adquirido, em função de seu preço. Isto é, gênero não afeta essa avaliação.

\section{Gráfico 46 - Associação Gênero e Satisfação Durabilidade do Produto}




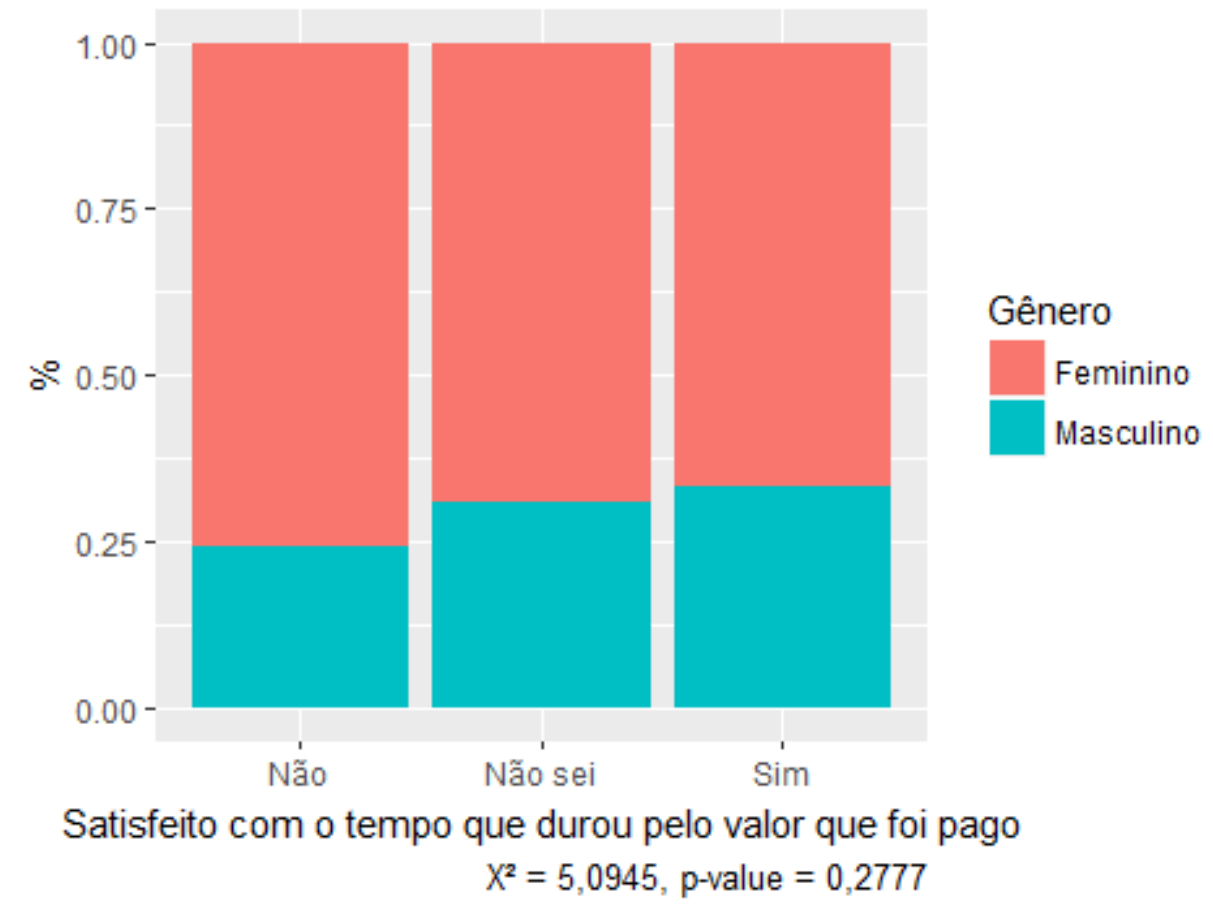

Homens aparentam ter um domínio maior sobre o termo obsolescência programada do que mulheres, à luz do gráfico a seguir.

\section{Gráfico 47 - Associação Gênero e Conhecimento Obsolescência Programada}

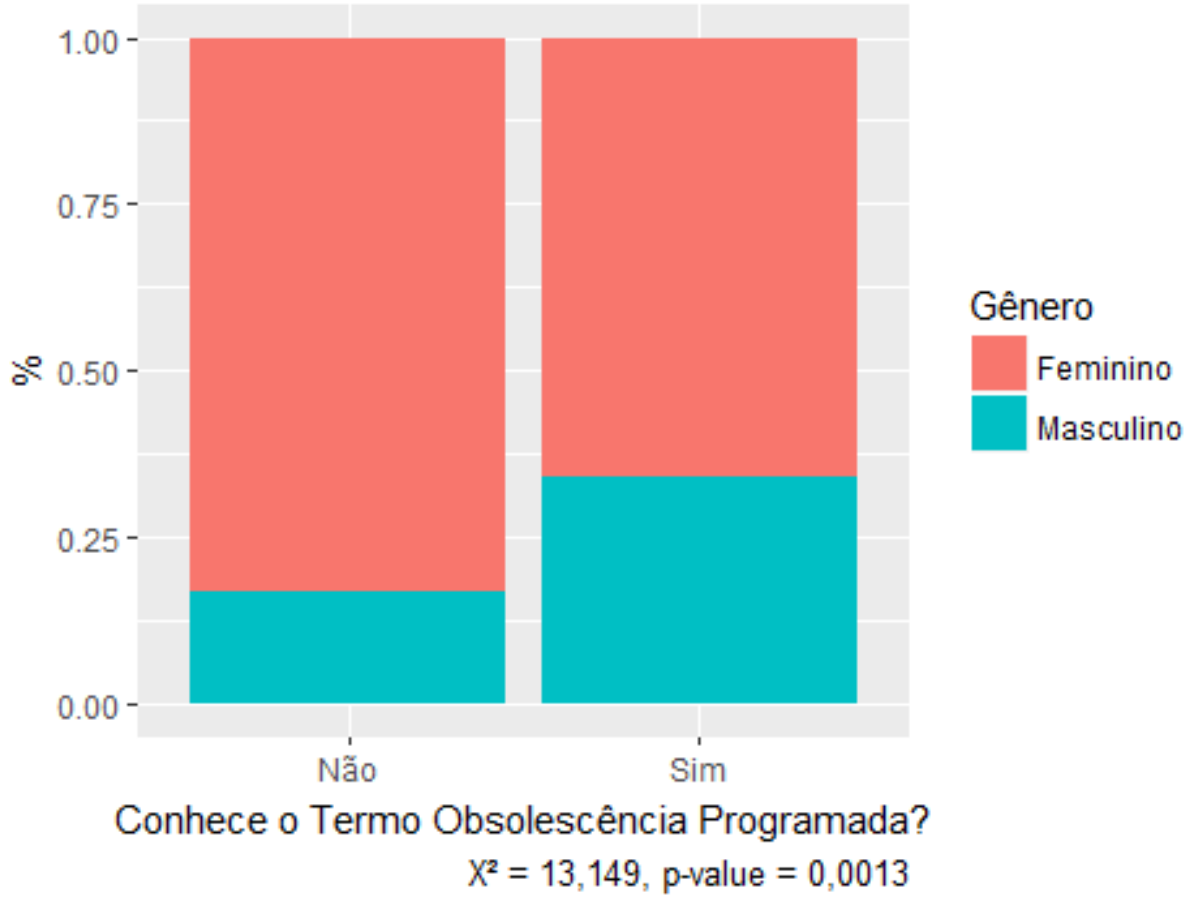

Por fim, ainda que proporcionalmente mais homens tivessem comprado um bem de consumo durável mesmo se o anterior não tivesse quebrado, gênero e esse tipo de compra não estão estatisticamente associados.

Gráfico 48 - Associação Gênero e Compra de Produto Após Quebra 


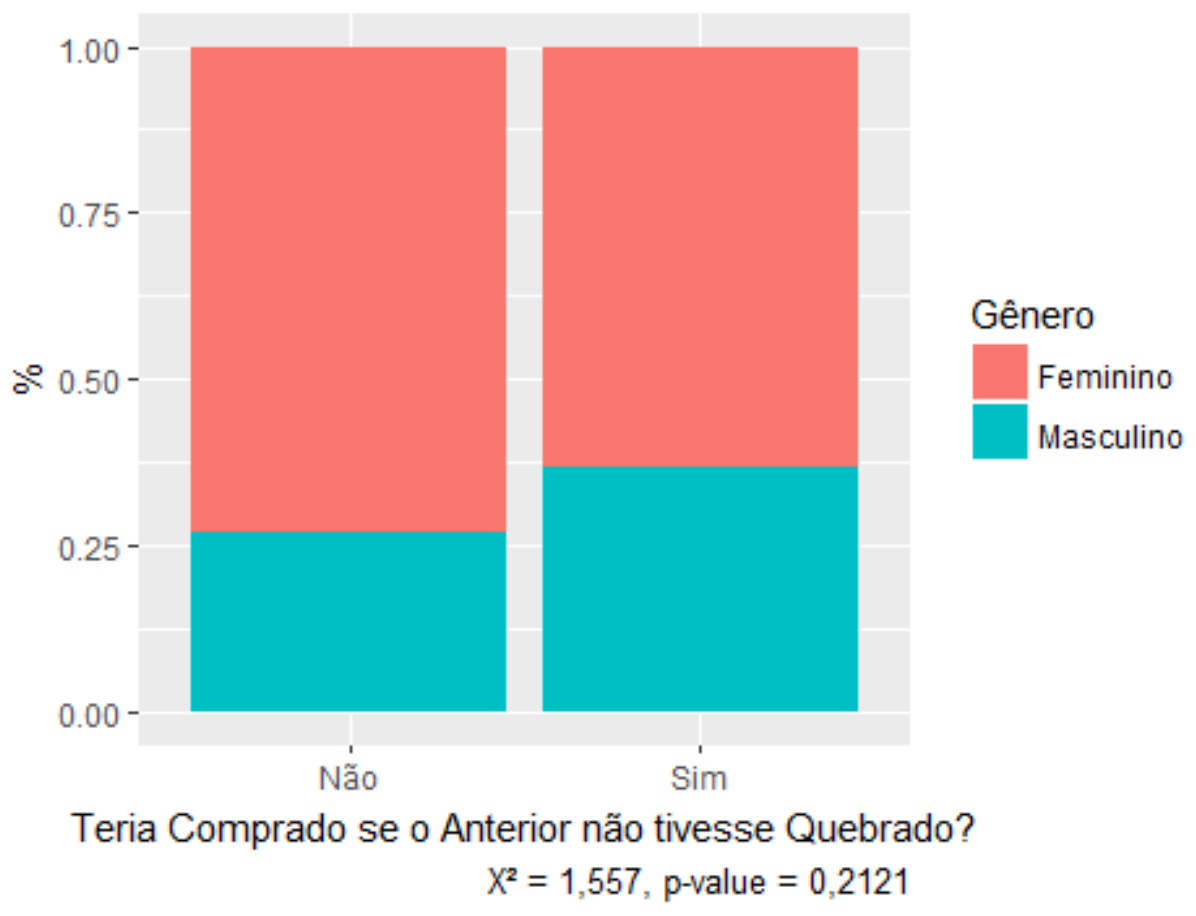

\section{Renda Familiar}

Sobre renda familiar, é necessário frisar que pela distribuição dos respondentes ser assimétrica, concentrada nos estratos com maior poder aquisitivo, reorganizamos os respondentes em 4 categorias diferentes. A primeira é composta por indivíduos que estão em famílias que auferem até 3 salários mínimos, a seguinte composta por domicílios que têm entre 3 e 5 salários mínimos, a próxima entre 5 e 7 , enquanto que a última congrega todos aqueles que recebem mais de 7 salários mínimos.

Assim sendo, podemos encontrar uma associação entre a renda familiar e a importância da assistência técnica. Indivíduos que estão na categoria de até 3 salários mínimos, os mais pobres, atribuem maior importância à assistência técnica, na verdade, quanto maior a renda, menor a importância da assistência técnica, já que o segmento de cada renda é progressivamente maior na coluna daqueles que afirmaram que a assistência não é importante, algo também apontado pelo p-value de 0,005.

\section{Gráfico 49 - Associação Renda Familiar e Relevância Assistência Técnica}




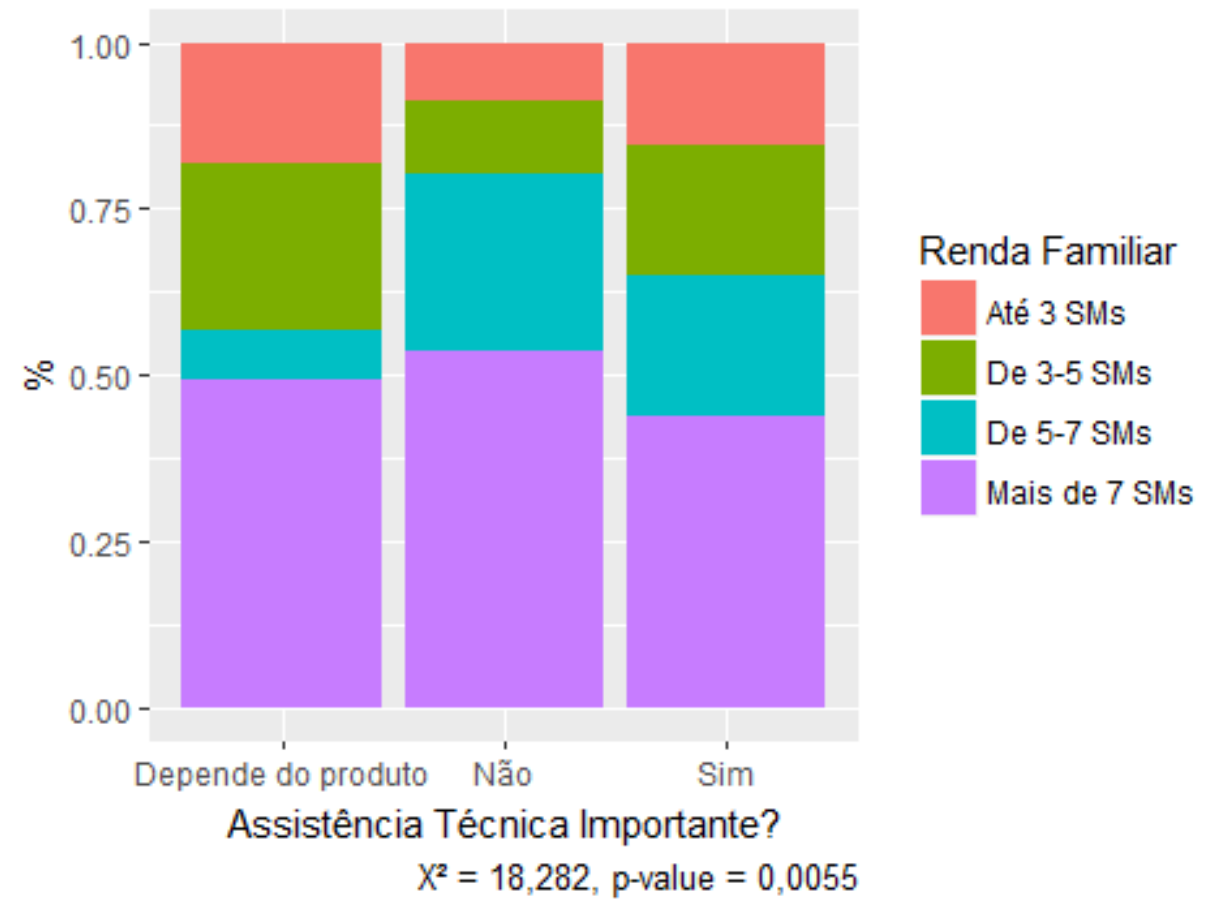

O mesmo não se pode ver em relação à compra de produtos usados. Essas duas variáveis não estão associadas.

\section{Gráfico 50 - Associação Renda Familiar e Aquisição Produtos Usados}

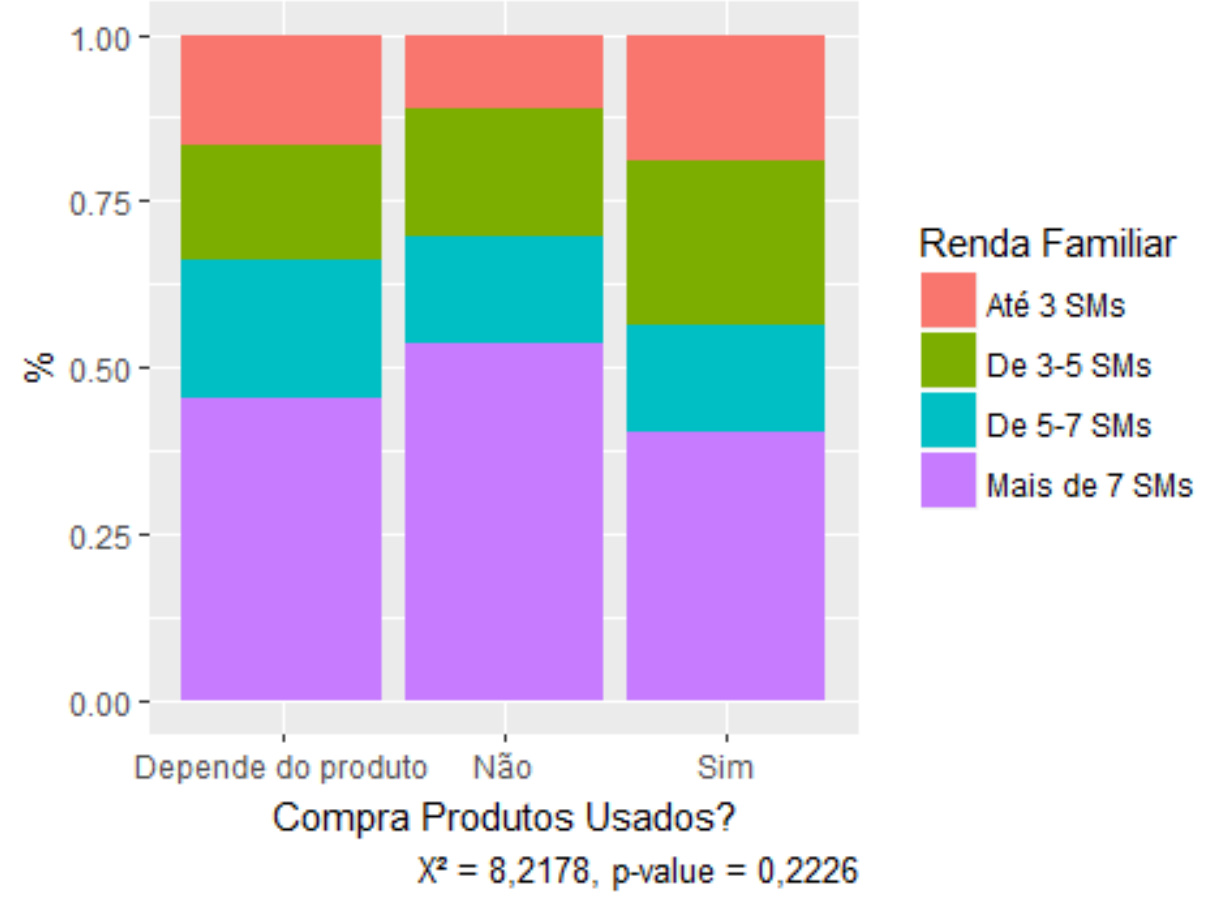

Ainda que a proporção de indivíduos na categoria com no mínimo 7 salários mínimos seja maior entre os pagamentos parcelados, essa diferença não é estatisticamente significante, como se vê abaixo.

Gráfico 51 - Associação Renda Familiar e Forma de Pagamento 


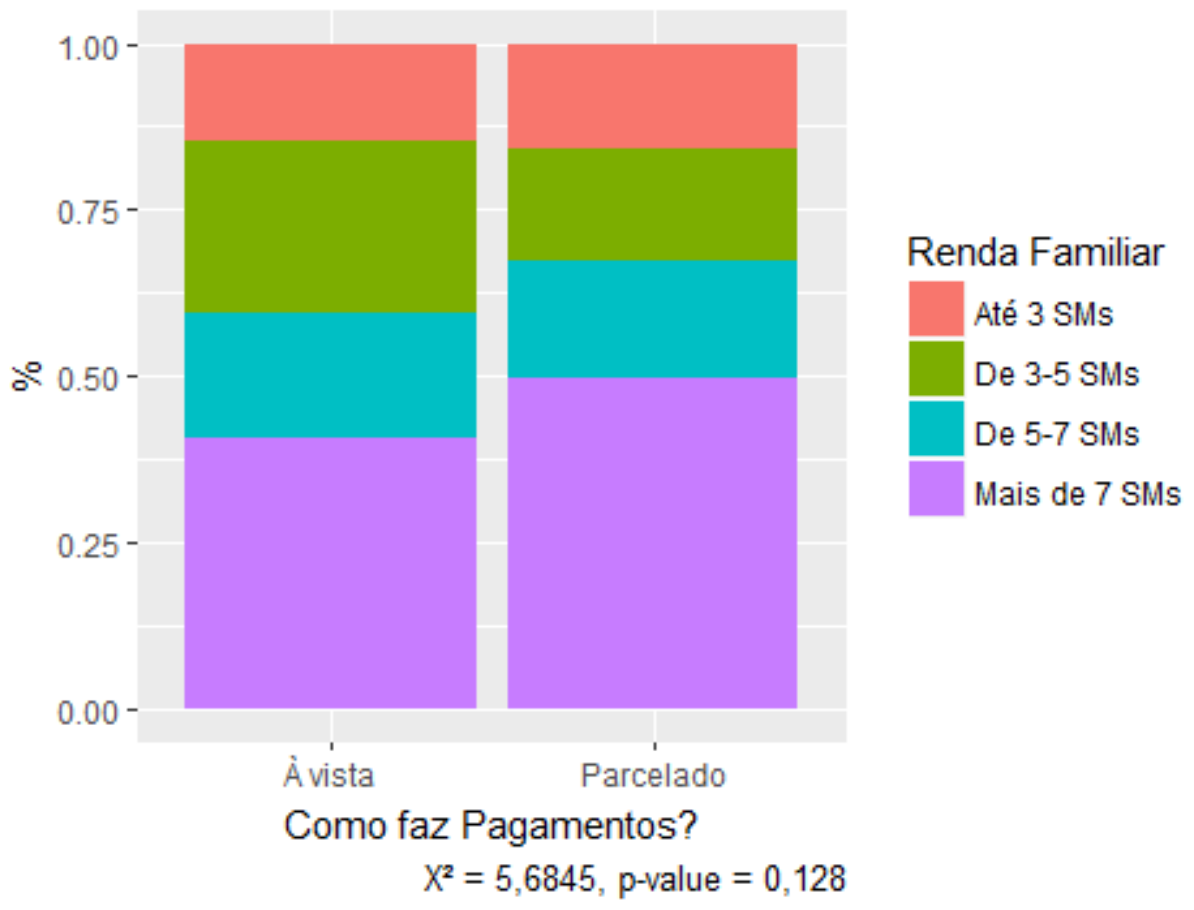

Em relação às demais variáveis consideradas aqui, a renda familiar também não está associada à concordância com a frase "Se é caro, deve durar muito", à satisfação com o tempo de duração do produto e o conhecimento do termo "obsolescência programada", como ilustram os três gráficos abaixo, respectivamente.

Gráfico 52 - Associação Renda Familiar e Concordância "Se é caro, deve durar muito"

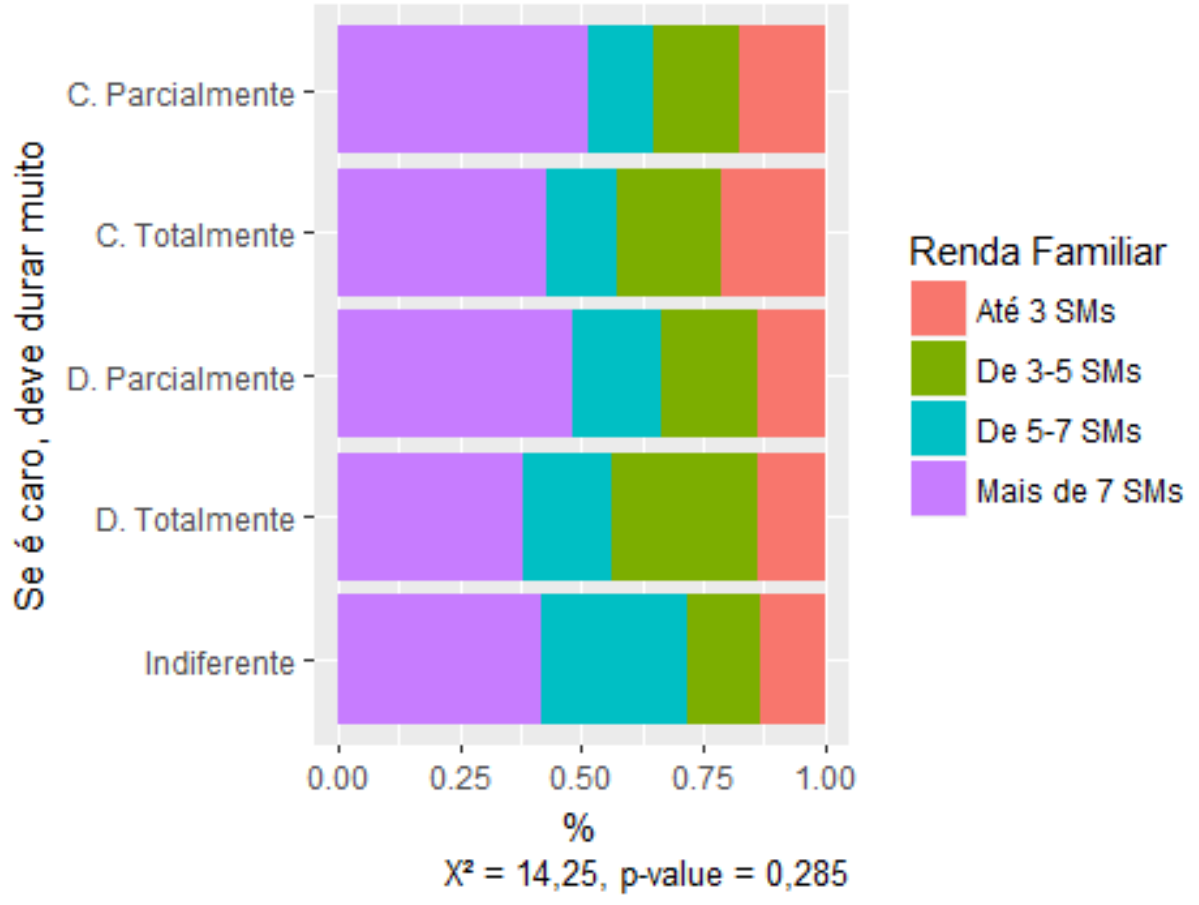

Gráfico 53 - Associação Renda Familiar e Satisfação Durabilidade Produto 


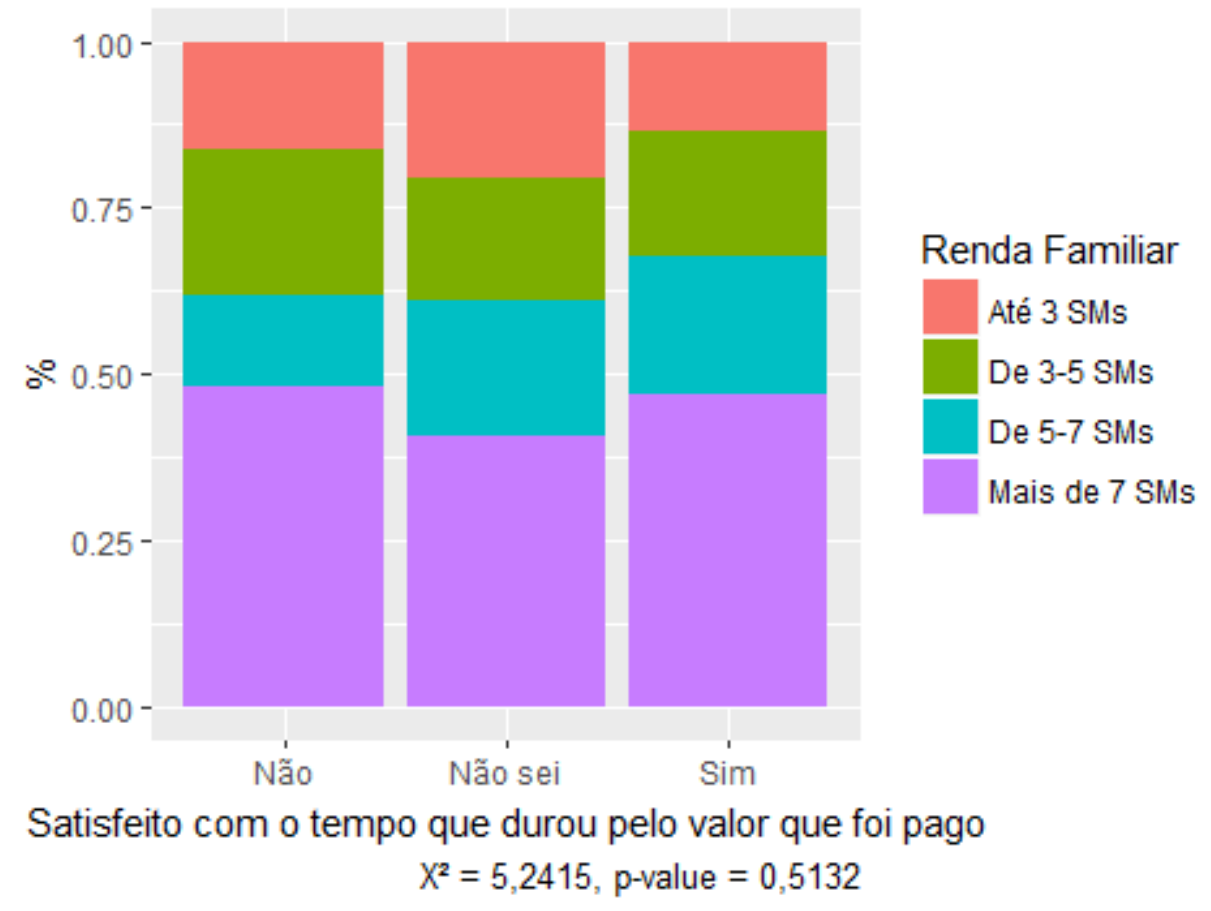
Gráfico 54 - Associação Renda Familiar e Conhecimento Obsolescência
Programada

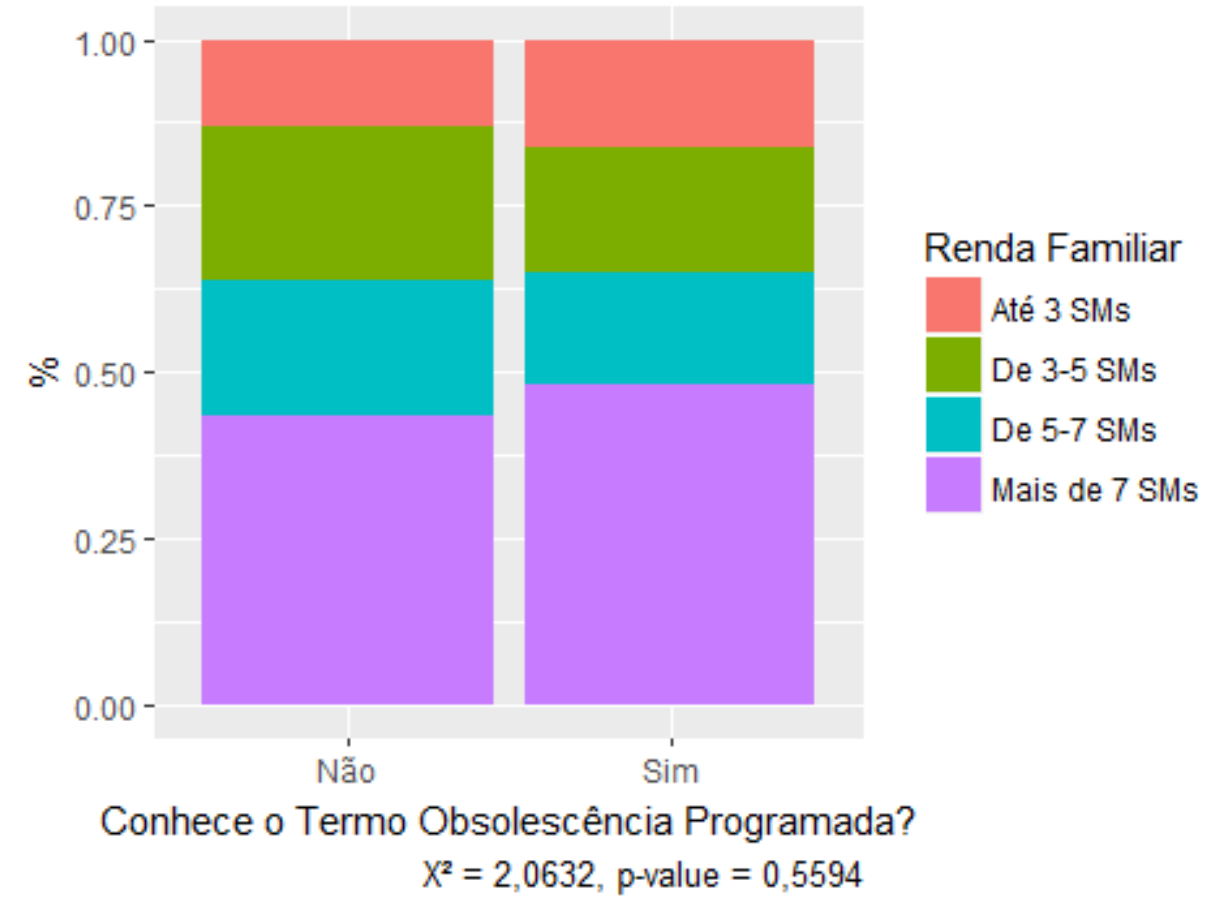

\section{Meio de Pagamento}

Pode-se observar que há uma associação entre o meio de pagamento e a relevância da assistência técnica. Proporcionalmente, entre aqueles que pagam seus produtos à vista, a assistência técnica é menos importante (p-value: 0,026).

Gráfico 55 - Associação Forma de Pagamento e Relevância Assistência Técnica 


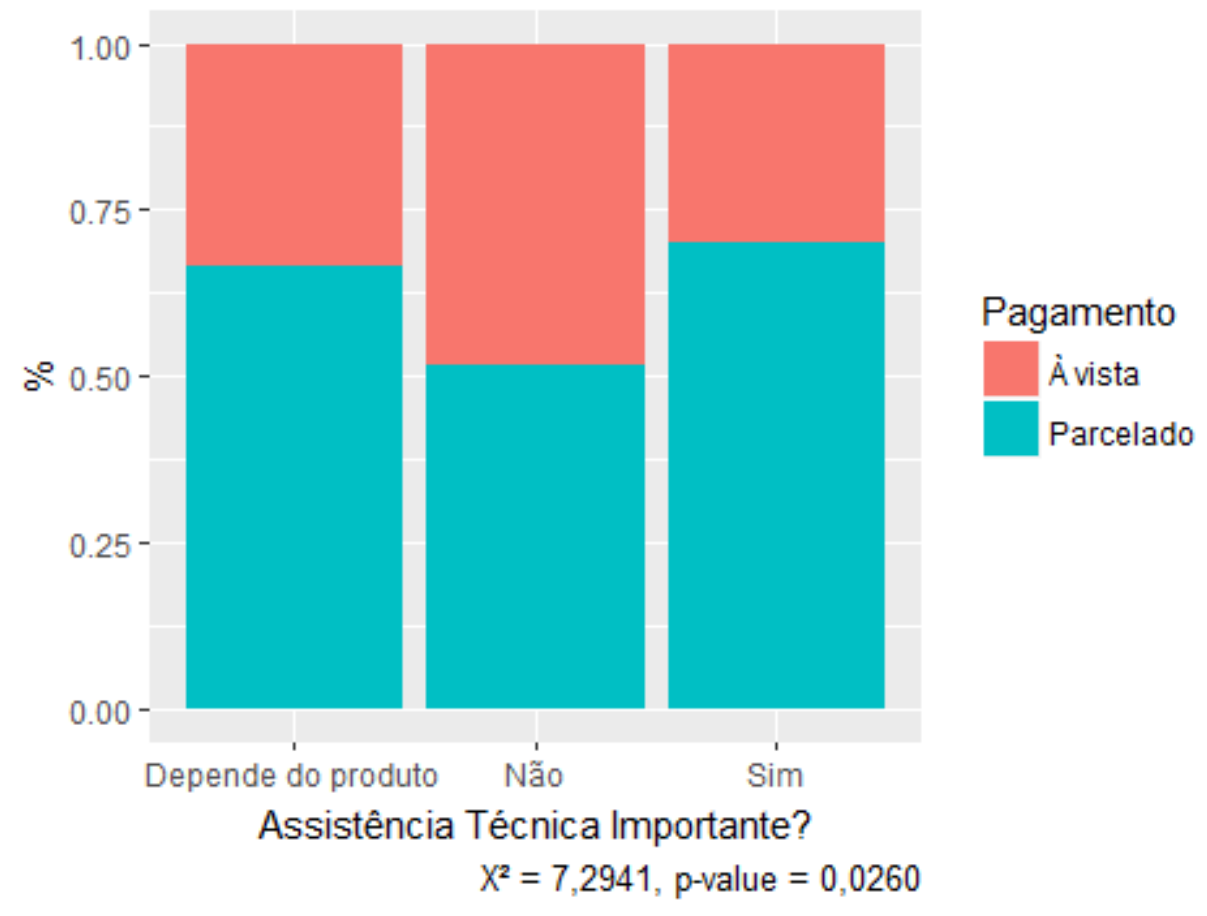

Contudo, o meio de pagamento não influi sobre a compra de produtos usados, a concordância com a frase "se é caro, deve durar muito" e a satisfação com o tempo que o produto durou.

\section{Gráfico 56 - Associação Meio de Pagamento e Compra de Produtos Usados}

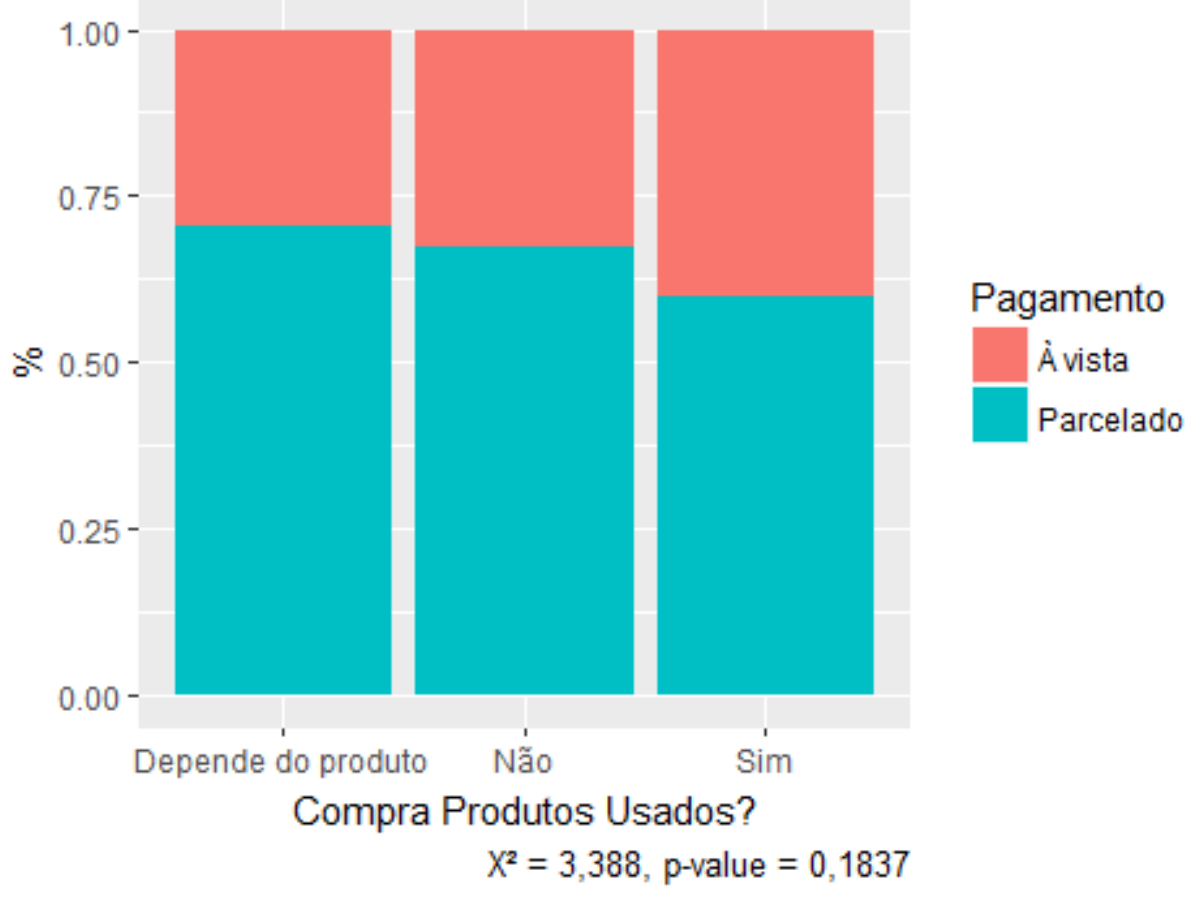

Gráfico 57 - Associação Forma de Pagamento e Concordância com "Se é caro, deve durar muito" 


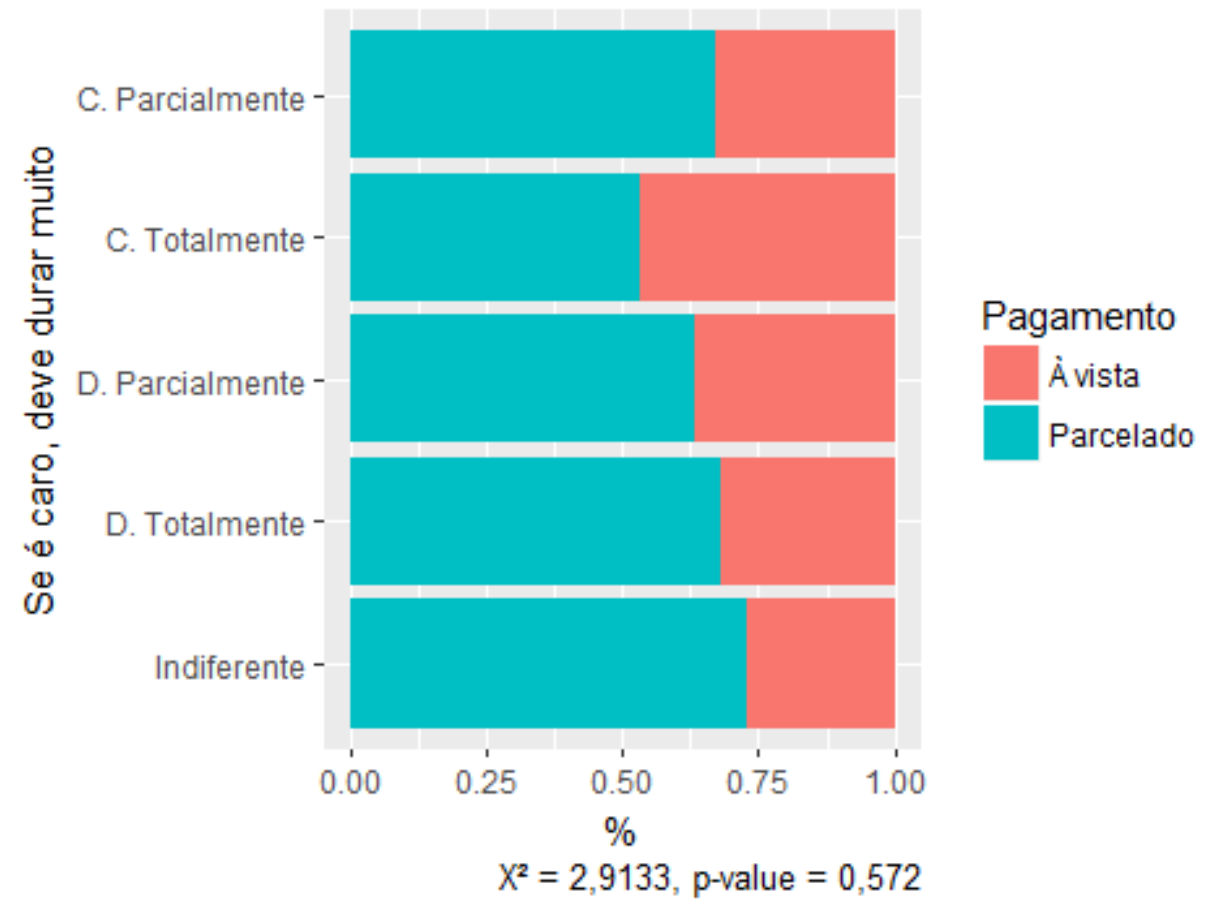

Gráfico 58 - Associação Forma de Pagamento e Satisfação com a Durabilidade do Produto

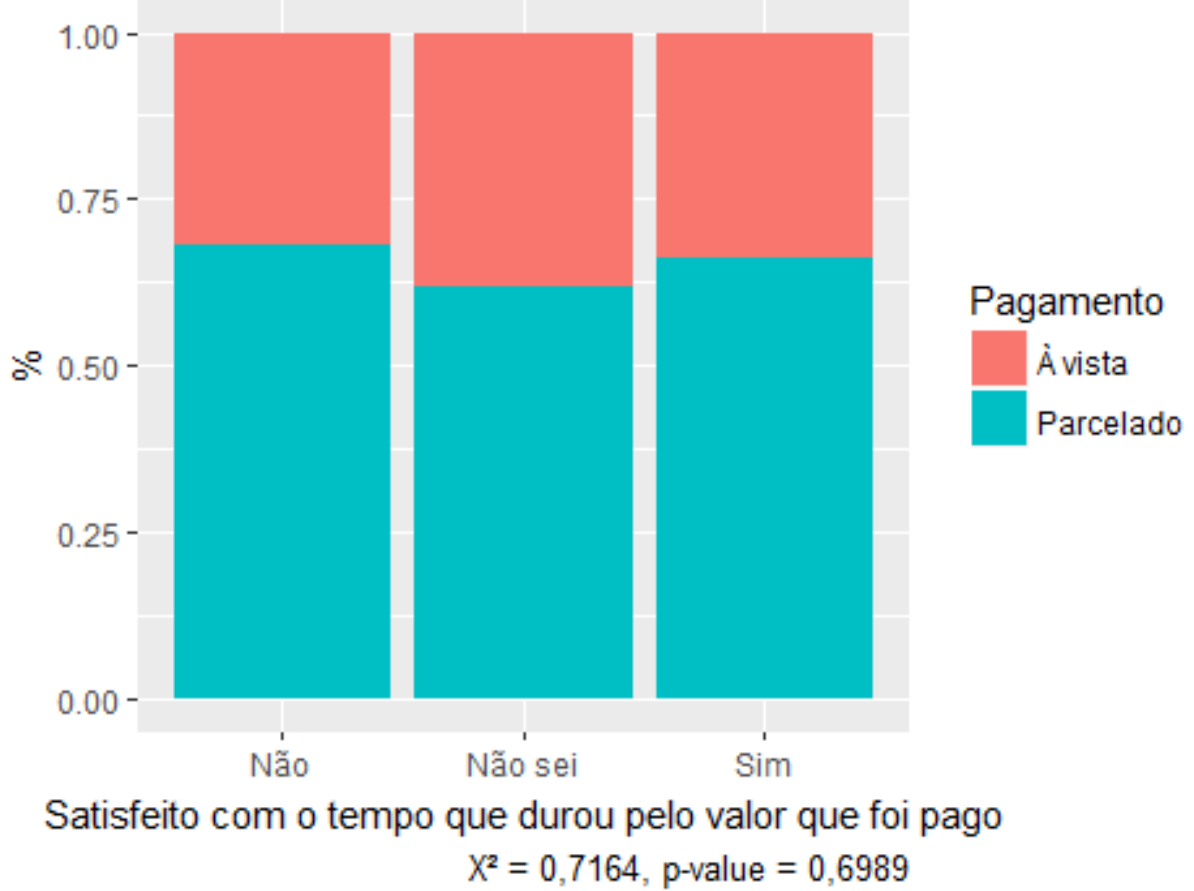

Porém, entre aqueles que fazem pagamentos à vista, proporcionalmente o conhecimento do termo de obsolescência programada é maior, conforme ilustra o pvalue estimado de 0,007 .

Gráfico 59 - Associação Meio de Pagamento e Conhecimento "Obsolescência Programada" 


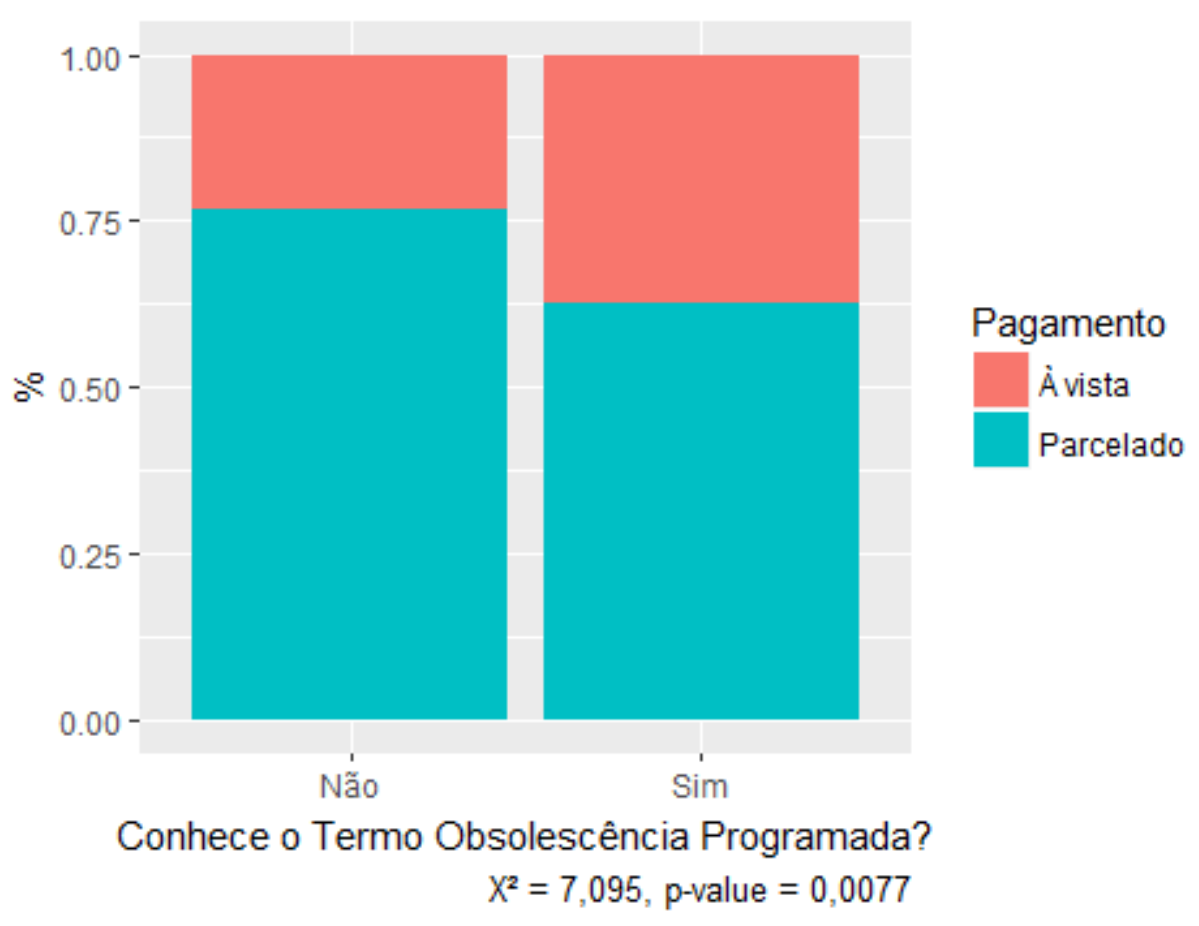

\section{Clivagem profissional: Designers}

Conforme a pergunta relacionada a profissões, registramos todos aqueles casos de respondentes que se identificaram como designers, independentemente do tipo. Ou seja, consideramos como designers todos aqueles que afirmaram ser "designers gráficos”, designers e professores, ou apenas designers. Sendo assim, possuímos 38 designers nessa pesquisa.

\section{Tabela 2 - Distribuição de Profissões}

\begin{tabular}{lcc}
\hline Profissão & $\mathbf{N}$ & $\%$ \\
\hline Designer & 38 & $8,5 \%$ \\
Outra & 409 & $91,5 \%$ \\
\hline Total & 447 & $100,0 \%$ \\
\hline
\end{tabular}

No caso, de todas as variáveis solicitadas para cruzamento com a profissão do respondente, apenas o conhecimento do termo obsolescência programa, antes de sua apresentação quando da aplicação do questionário, se mostrou estatisticamente associada. Já que proporcionalmente, designers têm maiores chances de conhecerem o termo obsolescência programada, conforme tabela abaixo ${ }^{3}$.

Tabela 3 - Teste de Associação entre Profissão e Conhecimento de Obsolescência Programada

\begin{tabular}{lrrrrr}
\hline \multirow{2}{*}{ P49 } & \multicolumn{2}{c}{ Não } & \multicolumn{2}{c}{ Sim } & Total \\
& $\mathbf{N}$ & $\%$ & $\mathbf{N}$ & $\%$ & $\mathbf{N}$ \\
\hline Designer & 4 & $3 \%$ & 34 & $10 \%$ & 38
\end{tabular}

${ }^{3}$ Reforçando, o valor crítico para uma associação estatisticamente significante é um p-valor inferior a 0,05 ; valor escolhido arbitrariamente para essa pesquisa. Assim, na tabela 2 , há associação estatística, pois o p-valor auferido foi de 0,02 , enquanto que os outros valores na planilha de Excel encaminhada são sempre superiores a 0,05 . 


\begin{tabular}{lccccc} 
Outra & 116 & $97 \%$ & 290 & $90 \%$ & 406 \\
\hline Total & 120 & $100 \%$ & 324 & $100 \%$ & 444 \\
\hline p-value & & & & & $\mathbf{0 , 0 2 0}$ \\
\hline
\end{tabular}

\section{Clivagem do Motivo por Ter Comprado o Último Produto}

Solicitou-se que se testasse a associação entre o motivo pelo qual o respondente comprou o último aparelho e o tipo de bem adquirido, bem como a forma de pagamento. Aqui algumas considerações são válidas:

- O principal motivo pelo respondente ter comprado um eletrodoméstico grande foi de que o anterior quebrou;

- Para o eletrodoméstico pequeno, a compra ocorreu, pois antes o respondente não tinha;

- Para celulares, há uma divisão entre o fato do anterior ter quebrado ou não atender mais às necessidades do participante;

- Eletrônicos são adquiridos, pois anteriormente os respondentes não tinham um;

- Computadores são adquiridos pelas mesmas razões que os celulares;

- Enquanto que móveis são adquiridos pelos mesmos motivos que eletrônicos;

- A associação estatística revela que bens de consumo durável diferentes são adquiridos por motivos - obsolescências - diferentes.

Por outro lado, não existe associação estatística entre a forma de pagamento e a necessidade pela qual o bem foi adquirido. 
Tabela 4 - Associação Bem Adquirido e Motivo para Aquisição

\begin{tabular}{|c|c|c|c|c|c|c|c|c|}
\hline P31 & & Não tinha & $\begin{array}{c}\text { Modelo mais bonito } \\
\text { lançado }\end{array}$ & Anterior Quebrou & $\begin{array}{c}\text { Não atendia às } \\
\text { necessidades }\end{array}$ & $\begin{array}{c}\text { Tecnologicamente } \\
\text { Ultrapassado }\end{array}$ & Total & $p$-value \\
\hline \multirow{2}{*}{ Eletrodomésticos Grandes } & $\mathbf{N}$ & 21 & 0 & 36 & 13 & 3 & 73 & \\
\hline & $\%$ & $29 \%$ & $0 \%$ & $49 \%$ & $18 \%$ & $4 \%$ & $100 \%$ & \\
\hline \multirow{2}{*}{ Eletrodomésticos Pequenos } & $\mathbf{N}$ & 26 & 0 & 22 & 5 & 2 & 55 & \\
\hline & $\%$ & $47 \%$ & $0 \%$ & $26 \%$ & $8 \%$ & $4 \%$ & $100 \%$ & \\
\hline \multirow{2}{*}{ Celulares } & $\mathbf{N}$ & 7 & 1 & 72 & 37 & 15 & 132 & \\
\hline & $\%$ & $5 \%$ & $0 \%$ & $28 \%$ & $20 \%$ & $10 \%$ & $100 \%$ & \\
\hline \multirow{2}{*}{ Eletrônicos } & $\mathbf{N}$ & 14 & 1 & 5 & 4 & 2 & 26 & $<0,001$ \\
\hline & $\%$ & $54 \%$ & $3 \%$ & $14 \%$ & $13 \%$ & $7 \%$ & $100 \%$ & \\
\hline \multirow{2}{*}{ Computadores } & $\mathbf{N}$ & 4 & 0 & 26 & 14 & 4 & 48 & \\
\hline & $\%$ & $8 \%$ & $0 \%$ & $28 \%$ & $21 \%$ & $8 \%$ & $100 \%$ & \\
\hline \multirow{2}{*}{ Móveis } & $\mathbf{N}$ & 14 & 0 & 2 & 6 & 0 & 22 & \\
\hline & $\%$ & $64 \%$ & $0 \%$ & $7 \%$ & $21 \%$ & $0 \%$ & $100 \%$ & \\
\hline Total & & 86 & 2 & 163 & 79 & 26 & 356 & \\
\hline
\end{tabular}


Tabela 5 - Associação Forma de Pagamento e Motivo pela Aquisição

\begin{tabular}{|c|c|c|c|c|c|}
\hline \multirow{2}{*}{ Pagamento } & \multicolumn{2}{|c|}{ À Vista } & \multicolumn{2}{|c|}{ Parcelado } & \multirow{2}{*}{ Total } \\
\hline & $\mathbf{N}$ & $\%$ & $\mathbf{N}$ & $\%$ & \\
\hline Não tinha & 31 & $24 \%$ & 69 & $27 \%$ & 100 \\
\hline Modelo mais bonito lançado & 1 & $1 \%$ & 3 & $1 \%$ & 4 \\
\hline Anterior Quebrou & 56 & $43 \%$ & 115 & $45 \%$ & 171 \\
\hline Não atendia às necessidades & 31 & $24 \%$ & 49 & $19 \%$ & 80 \\
\hline $\begin{array}{l}\text { Tecnologicamente } \\
\text { Ultrapassado }\end{array}$ & 10 & $8 \%$ & 20 & $8 \%$ & 30 \\
\hline Total & 98 & $100 \%$ & 187 & $100 \%$ & 385 \\
\hline p-value & & & & & 0,852 \\
\hline
\end{tabular}

\section{Faixa Etária}

Investiga-se aqui a associação entre faixa etária e uma bateria de itens de interesse da pesquisadora. Ao invés de utilizar a idade em sua forma discreta conforme coletada, optou-se por dividir os participantes dessa sondagem em dois grupos, divididos na mediana dessa população. Sendo a mediana igual a 39 anos, o grupo mais jovem possui até 39 anos, enquanto que o mais velho possui ao menos 40. A ideia de dividir a população em dois grupos visa facilitar a investigação do fator etário sobre as práticas de consumo registradas nessa pesquisa. Ademais, a formação de grupos no ponto mediano da amostra objetiva criar grupos que sejam numericamente equivalentes ${ }^{4}$.

Assim sendo, a assistência técnica se mostrou proporcionalmente mais importante para o grupo de respondentes mais velhos, contribuindo para um p-valor estatisticamente significante, à luz do gráfico abaixo.

\section{Gráfico 60 - Importância Assistência Técnica por Faixa Etária}

\footnotetext{
${ }^{4}$ Vale destacar que esses testes também foram realizados numa divisão etária mais complexa, em 5 categorias, compartimentando a população a cada 10 anos, isto é, de 15 a 25,26 a 35 e sucessivamente, até o grupo composto por indivíduos com ao menos 56 anos. Assim como na divisão exposta no corpo do texto, essa divisão não produziu resultados teoricamente relevantes. Por fim, poder-se-ia ter recorrido a técnicas estatísticas mais sofisticadas para formação desses grupos, como os chamados clusters. Porém, tal técnica foi preterida em função da natureza exploratória dessa sondagem.
} 


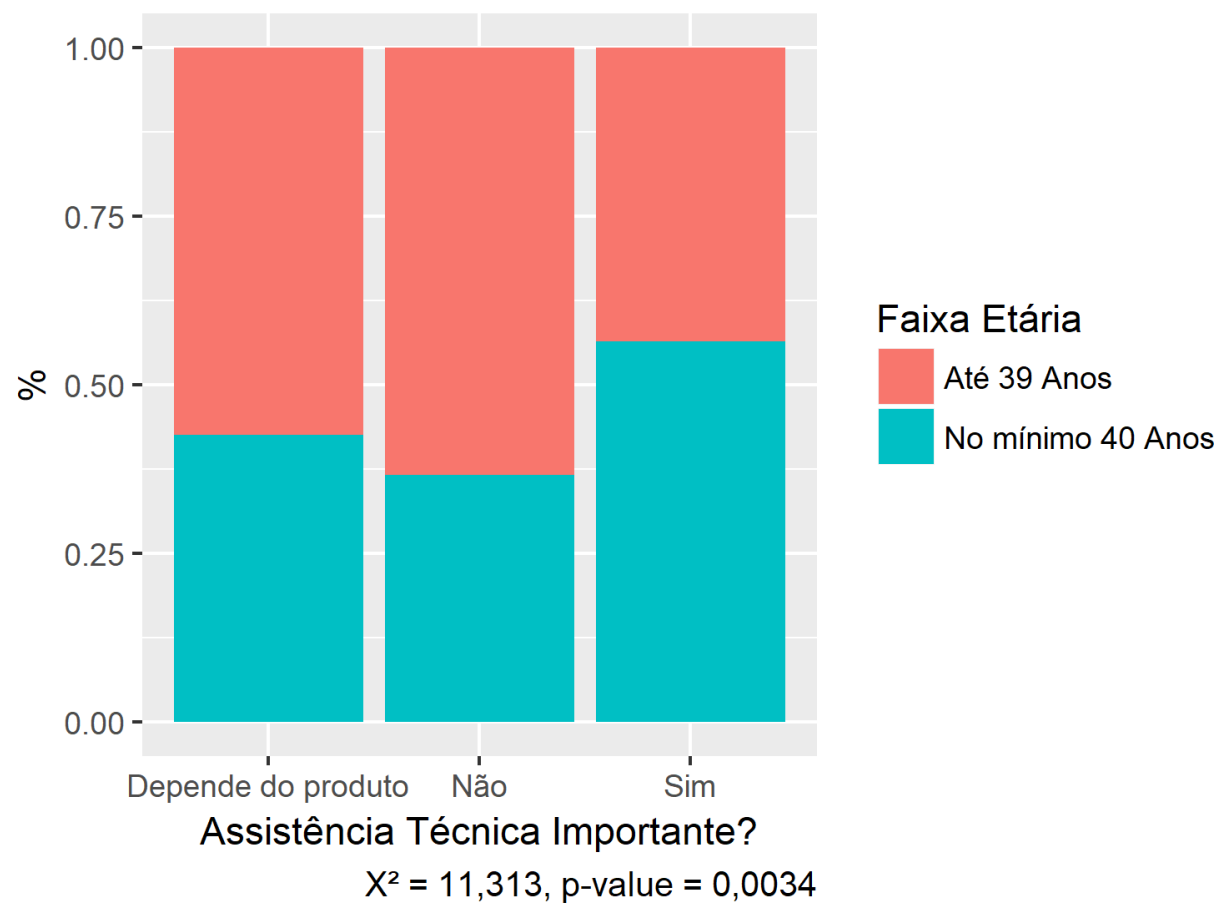

Além disso, o grupo mais velho discorda mais da ideia de que "se [o produto] é caro, [o mesmo] deve durar muito;

\section{Gráfico 61 - Concordância com "Se é caro, deve durar muito" por Faixa Etária}

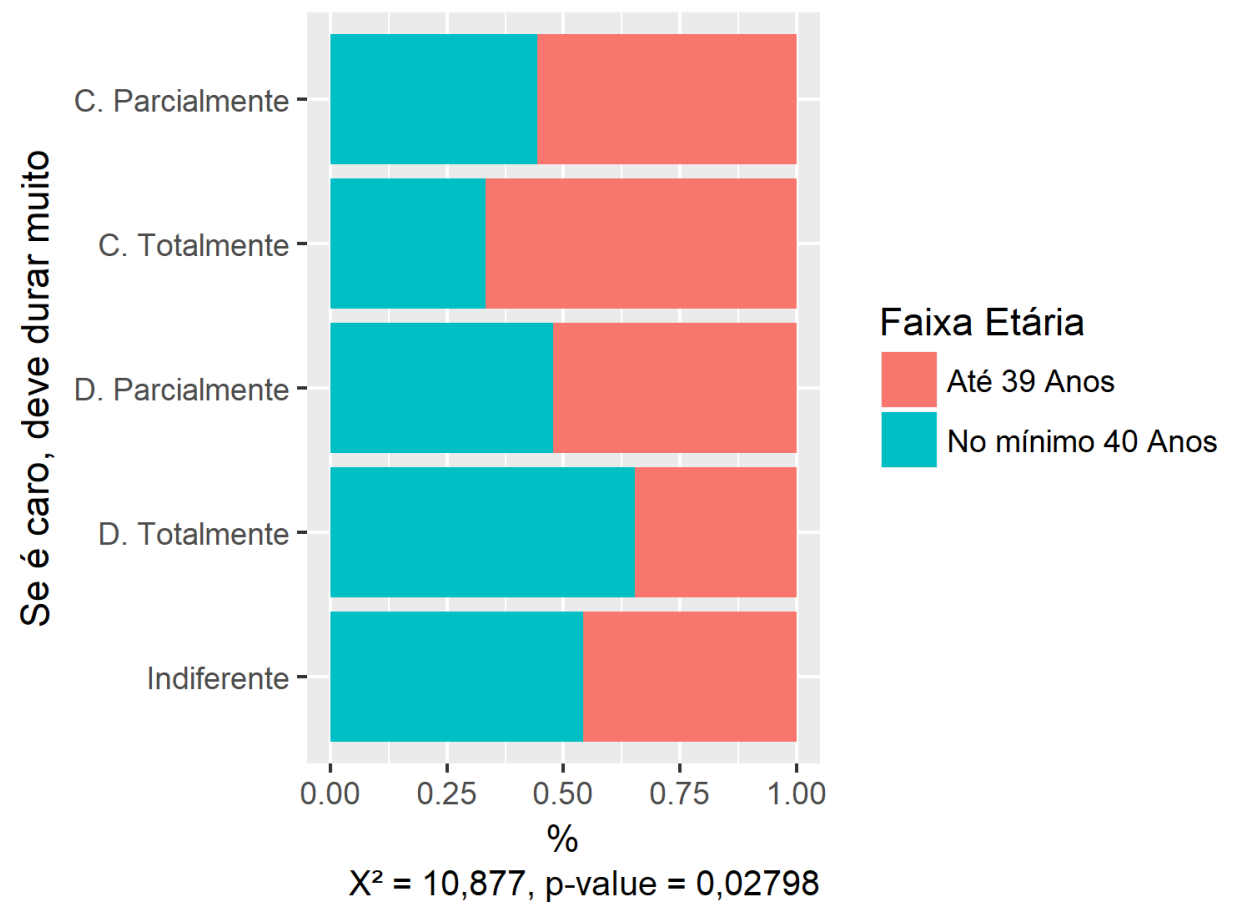

Inexiste associação entre faixa etária e desejo de que o produto tivesse durado mais.

Gráfico 62 - Desejo de maior durabilidade do produto por Faixa Etária 


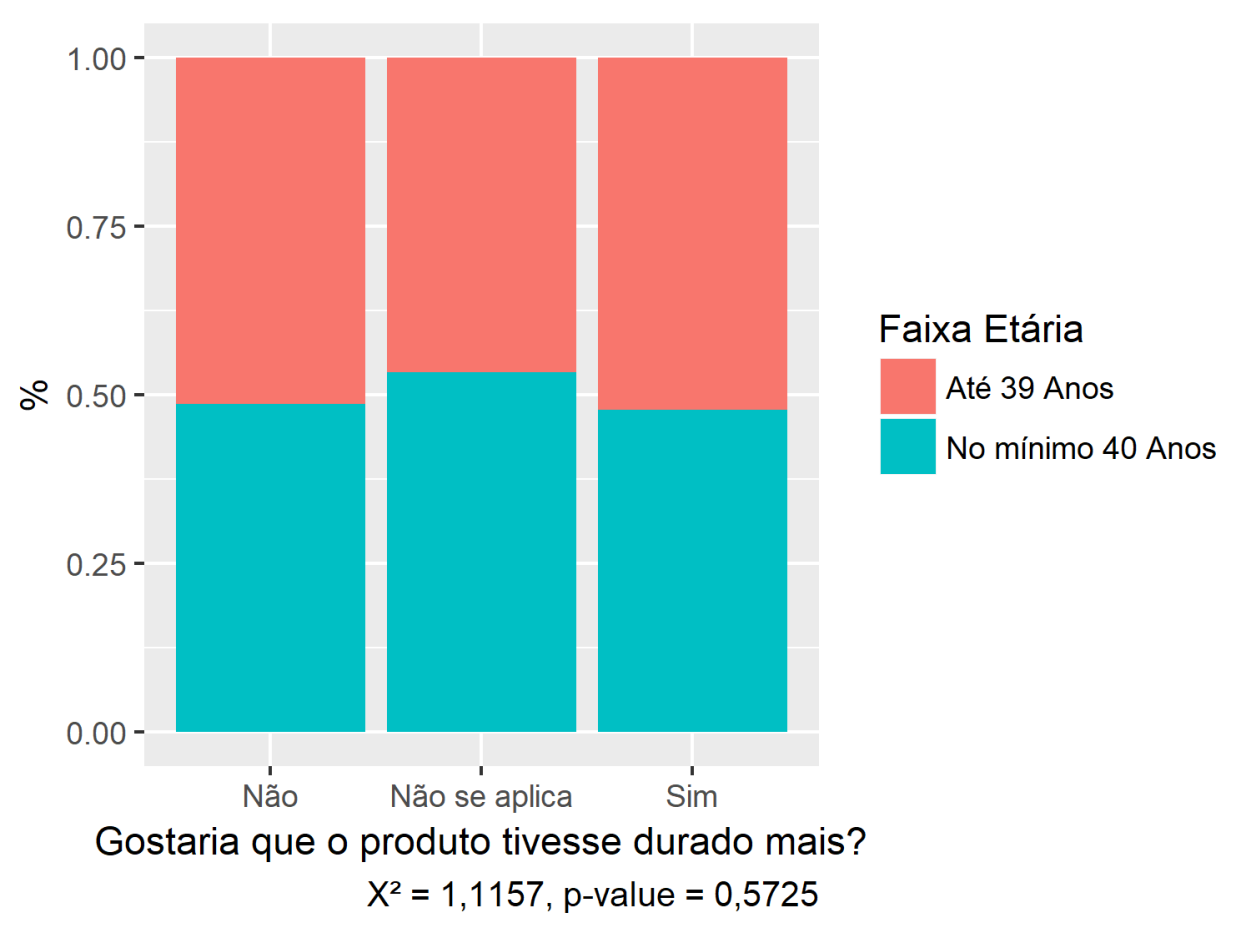

Respondentes mais velhos consideram menos a durabilidade no momento da compra do que o grupo de respondentes mais jovens, ante o resultado estatisticamente significante auferido abaixo, possivelmente conflitando com o teste significante coletado em relação à importância da assistência técnica no momento da compra.

\section{Gráfico 63 - Consideração da Durabilidade no Ato da Compra por Faixa Etária}

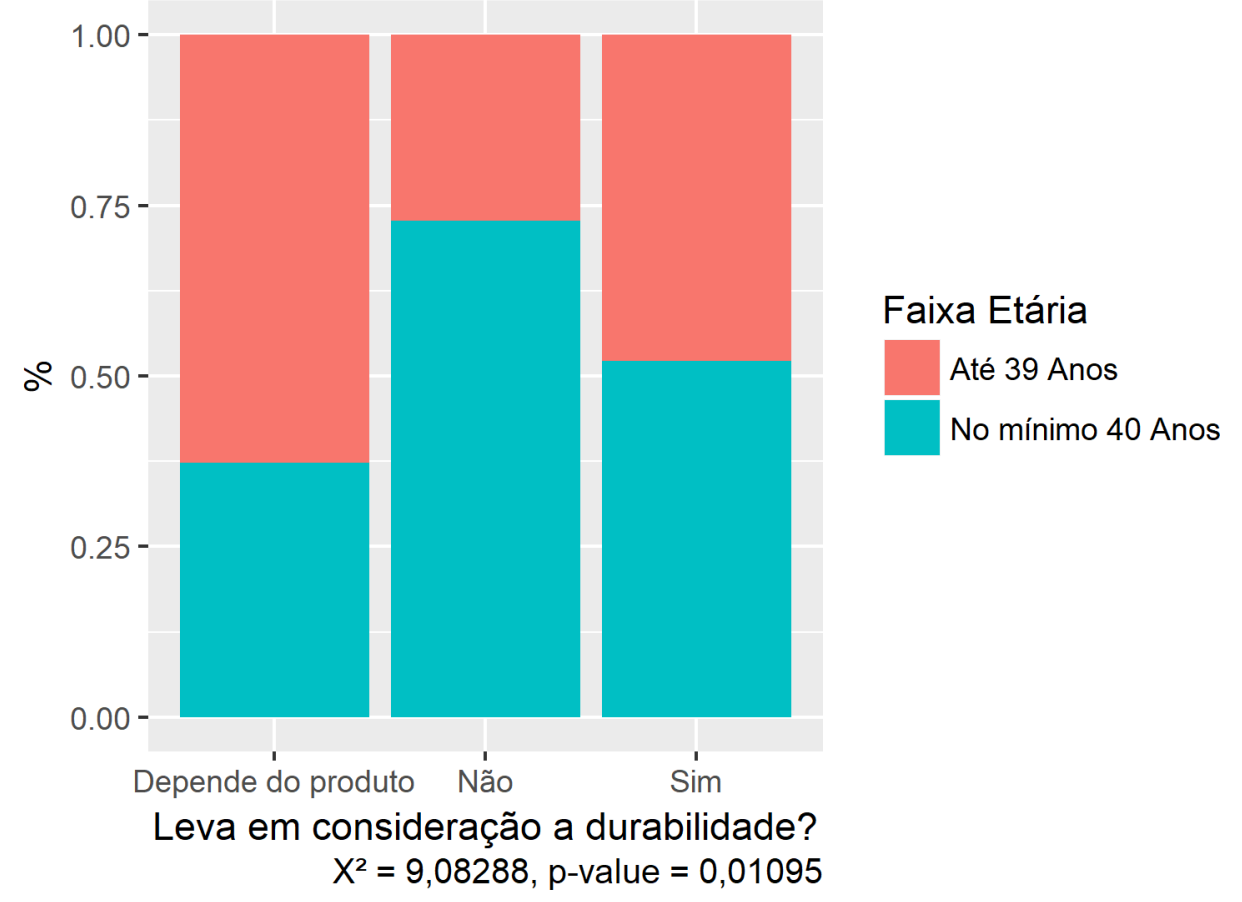

Respondentes mais velhos compram proporcionalmente mais parcelado do que à vista, em relação ao grupo mais jovem de respondentes. 


\section{Gráfico 64 - Meio de Pagamento por Faixa Etária}

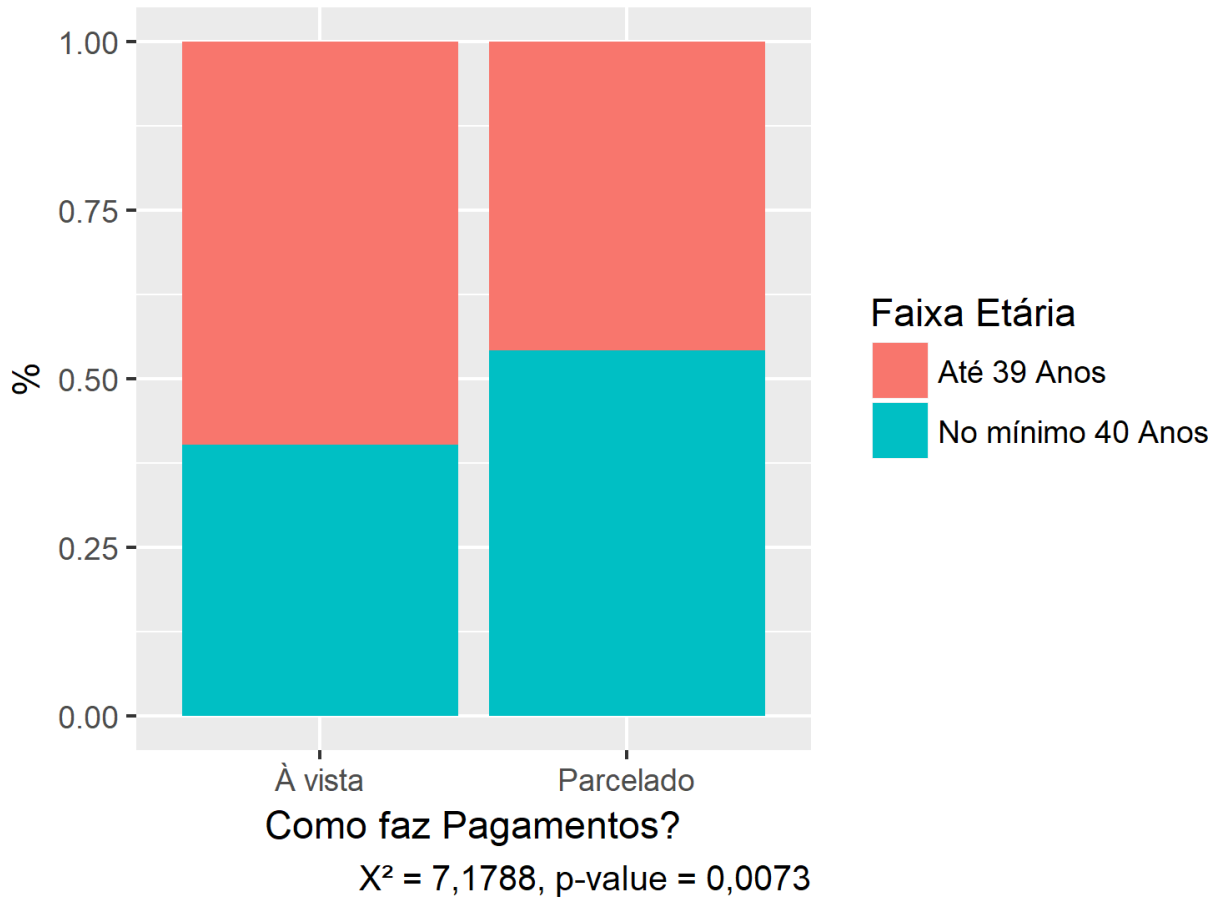

Nenhuma associação entre compra de um novo produto se o anterior não tivesse quebrado e faixa etária.

\section{Gráfico 65 - Aquisição de um novo produto por Faixa Etária}

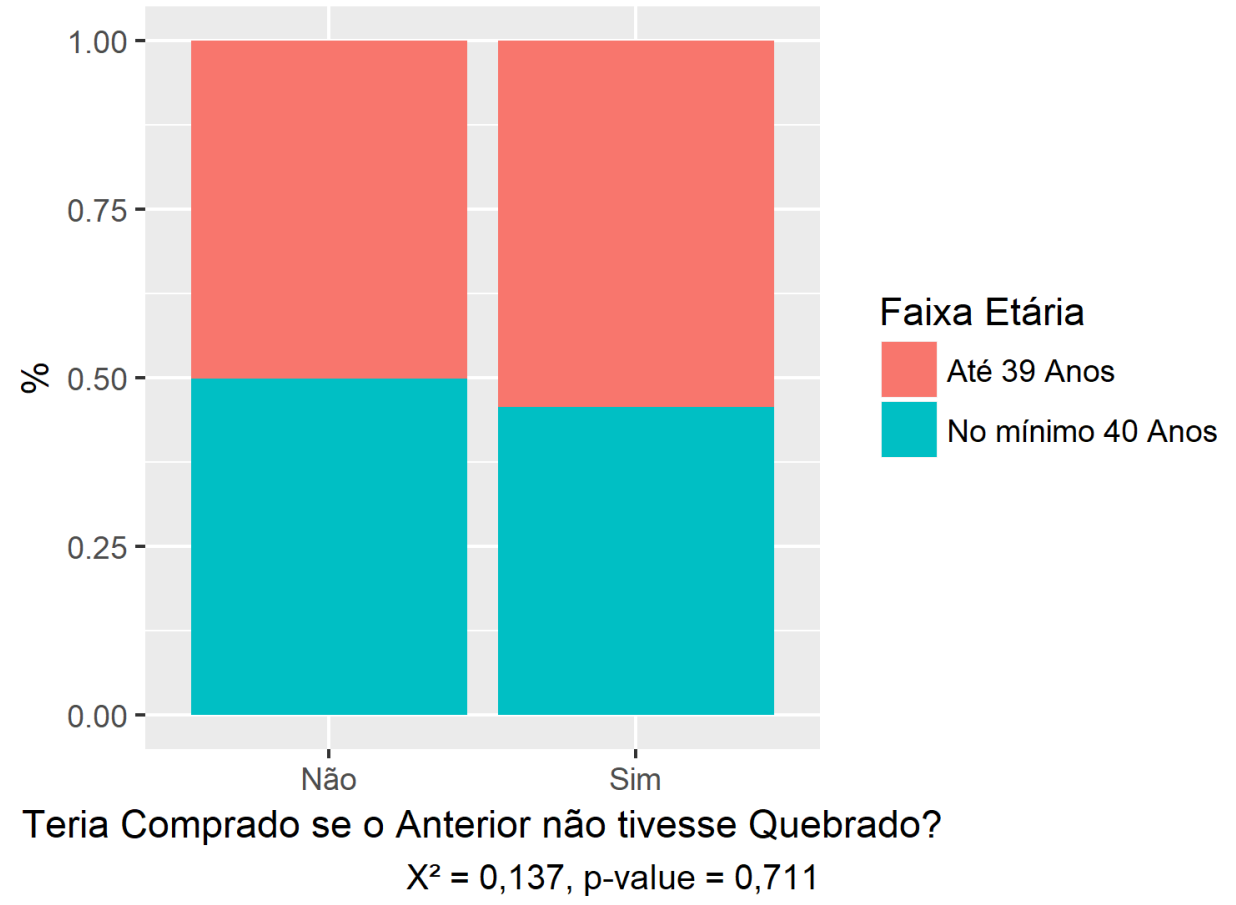

O mesmo acontece com a satisfação com a durabilidade do produto em função do valor pago.

Gráfico 66 - Associação Satisfação com a Durabilidade em Função do Valor por Faixa Etária 


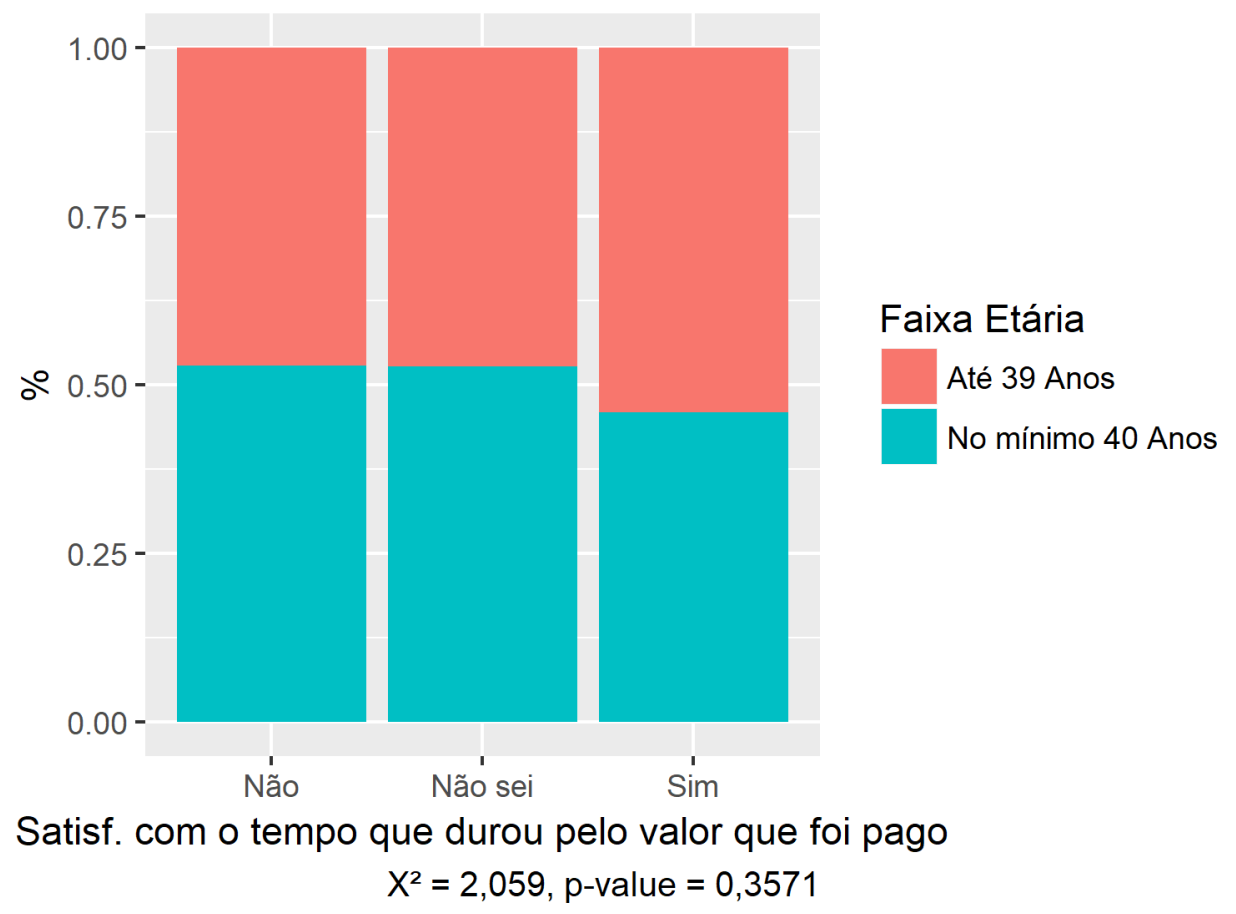

Não há associação estatística entre o conhecimento do termo obsolescência programada e a faixa etária.

\section{Gráfico 67 - Conhecimento do Termo Obsolescência Programada por Faixa Etária}

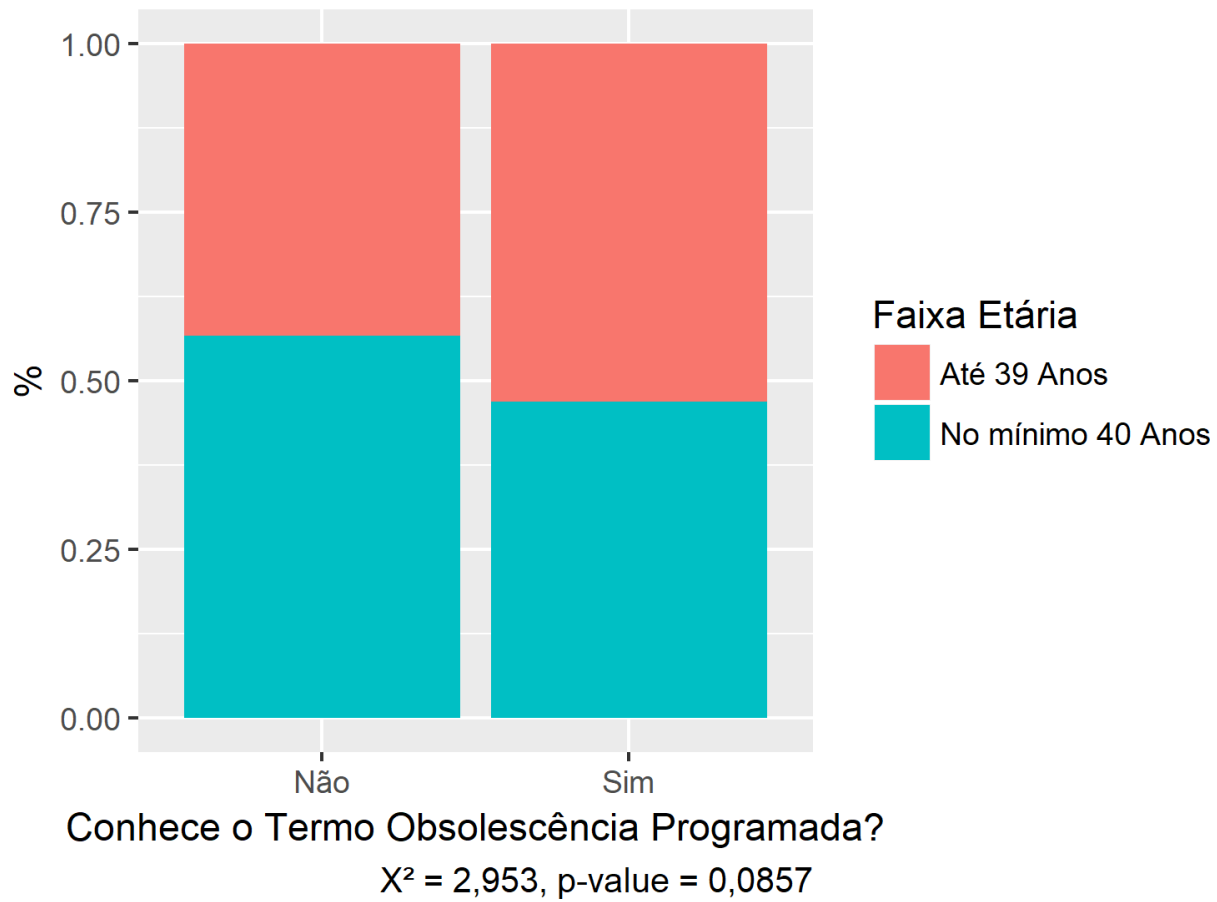

Não há associação entre o grupo etário dos respondentes e compra de produtos usados

Gráfico 68 - Compra de Produtos Usados por Faixa Etária 


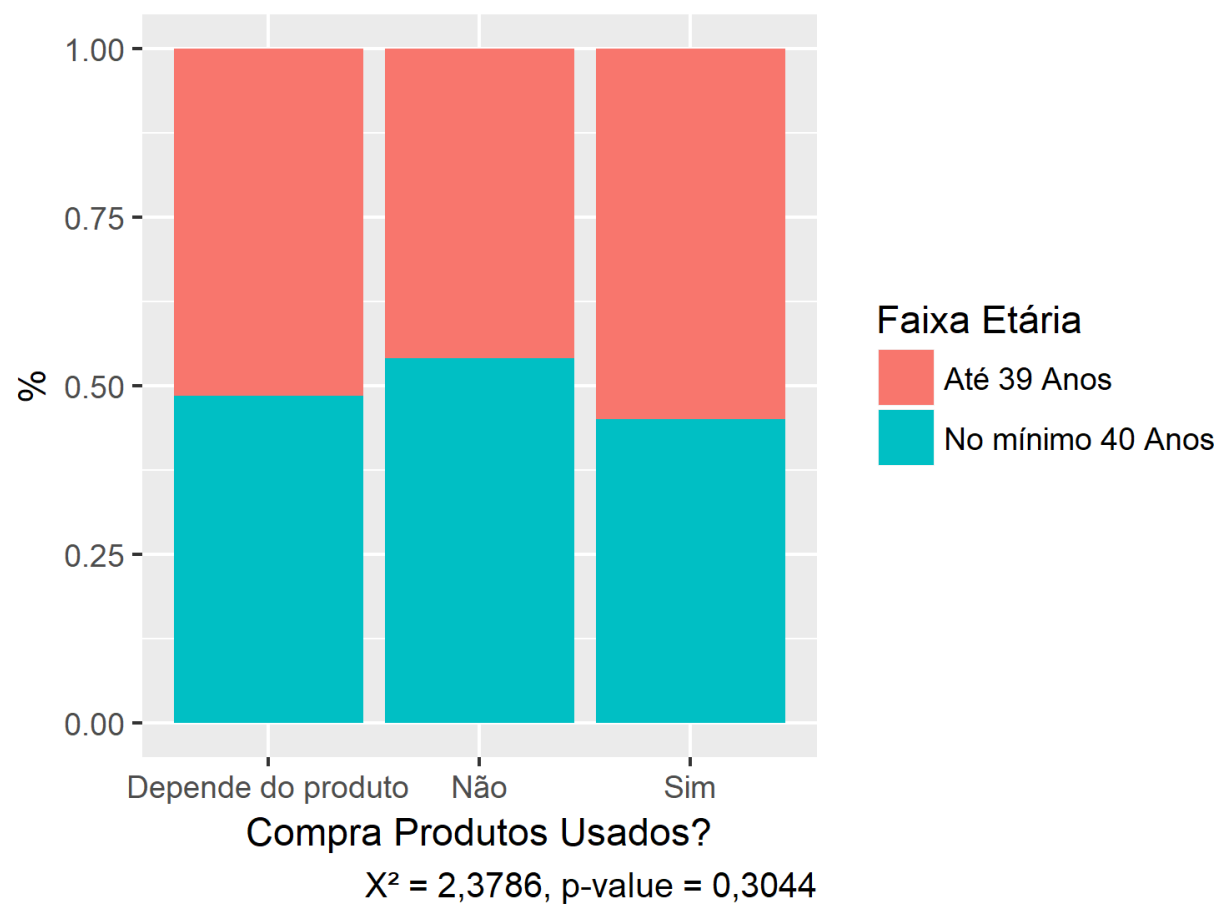

\section{Considerações Finais}

Não é demais reforçar que o questionário respondido por 444 pessoas constitui apenas uma sondagem, sem qualquer pretensão de produzir inferências sobre qualquer população mais abrangente. Consequentemente, tornar-se-ia interessante contrastar os valores obtidos nessa pesquisa com outras que tenham tido o interesse de mapear práticas de consumo de bens de consumo durável e sua relação com a obsolescência programada.

Além disso, nos testes de associação realizados, gênero, meio de pagamento e o grupo de designers não se mostraram teoricamente relevantes para as atitudes do questionário, como de início se esperava. Em relação à renda, esse se mostra como um fator a ser analisado em futuras pesquisas, já que os respondentes se concentraram num estrato de renda com alto poder aquisitivo, inviabilizando inferências ou comparações.

Por fim, a questão etária parece se apresentar como uma linha promissora de investigação, em função dos resultados estatisticamente significantes coletados. Contudo, o fato da idade estar associada de maneira divergente em relação à importância da assistência técnica e da durabilidade do produto no ato da compra impede que se trace uma hipótese inicial de como indivíduos de idades diferentes possuiriam perfis específicos em relação a bens de consumo durável, estratégias no consumo desses itens e relação com o termo obsolescência programada. 
10) 